Machteld Venken (ed.)

\title{
Borderland Studies Meets Child Studies
}

A European Encounter

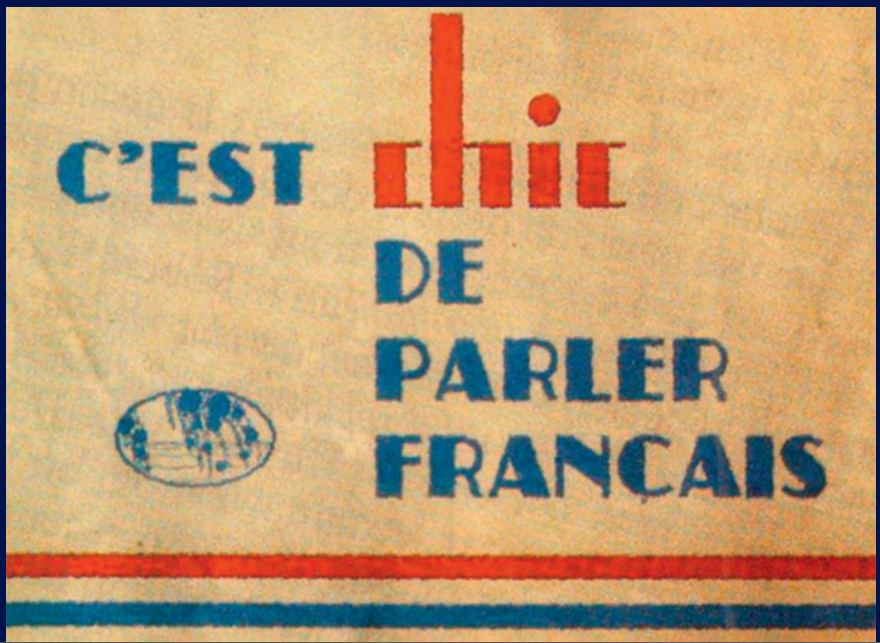




\section{Machteld Venken (ed.)}

\section{Borderland Studies Meets Child Studies}

This book provides a comparative analysis of the history of borderland children during the $20^{\text {th }}$ Century. More than their parents, children were envisioned to play a crucial role in bringing about a peaceful Europe. The contributions show the complexity of nationalisation within various spheres of borderland children's lives and display the dichotomy between nationalist policies and manifest non-national practices of borderland children. Despite the different imaginations of East and West that had influenced peace negotiators after both World Wars, moreover, borderland children in Western and Central Europe invented practices that contributed to the creation of a socially cohesive Europe.
The Author
Machteld Venken studied Slavic Studies at the Catholic University in Leuven and European Studies at the Jagiellonian University in Kraków. She holds a PhD in History from the Catholic University in Leuven. After holding postdoctoral fellowships in Warsaw, she is now an Elise Richter Fellow at the University of Vienna. 
Borderland Studies Meets Child Studies 


\section{STUDIES IN CONTEMPORARY HISTORY \\ Edited by Dariusz Stola / Machteld Venken}

VOLUME 6 
Machteld Venken (ed.)

\section{Borderland Studies Meets \\ Child Studies}

A European Encounter 


\section{Bibliographic Information published by the Deutsche Nationalbibliothek}

The Deutsche Nationalbibliothek lists this publication in the Deutsche Nationalbibliografie; detailed bibliographic data is available in the internet at http://dnb.d-nb.de.

Open Access: Except where otherwise noted, this work is licensed under a Creative Commons Attribution 4.0 unported license. To view a copy of this license, visit http://creativecommons.org/licenses/by /4.0/

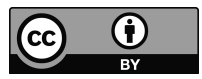

This edited volume was kindly supported by the

Austrian Science Fund (FWF) under the Elise Richter Grant V 360 - G 22.

Thanks to the additional publication grant PUB 401 - G 28 of FWF, the full edited volume is published in Open Access.

\section{FWF}

Der Wissenschaftsfonds

Cover image: 'It's chic to speak French' (Departmental archives of the Haut-Rhin (Colmar, France). 756.W.OD, 24.OD.378. Éclaireurs de France (1946-1965)). Photography: Julien Fuchs

ISSN 2364-2874

ISBN 978-3-631-67555-7 (Print)

E-ISBN 978-3-653-07080-4 (E-PDF)

E-ISBN 978-3-631-71210-8 (EPUB)

E-ISBN 978-3-631-71211-5 (MOBI)

DOI 10.3726/b11559

(c) Peter Lang $\mathrm{GmbH}$

Internationaler Verlag der Wissenschaften

Frankfurt am Main 2017

All rights reserved.

Peter Lang Edition is an Imprint of Peter Lang GmbH.

Peter Lang - Frankfurt am Main · Bern · Bruxelles · New York ·

Oxford $\cdot$ Warszawa $\cdot$ Wien

This publication has been peer reviewed.

www.peterlang.com 


\section{Acknowledgements}

This edited volume was kindly supported by the Austrian Science Fund (FWF) under the Elise Richter Grant V 360 - G 22. Thanks to the additional publication grant PUB 401 - G 28 of FWF, the full edited volume is published in Open Access.

Machteld Venken wishes to thank all the authors included in this edited volume for their useful comments on an earlier full version of the volume, as well as the anonymous peer reviewers for their helpful remarks. She is also grateful for the research assistance provided by Enno Lindemann and Marcin Bogusz, and the proofreading offered by Mark Trafford.

All maps, if not specified otherwise, are designed by Karol Perepłyś (Studio27, Warsaw). 



\section{Table of Content}

List of Figures, Illustrations and Maps..................................................................

Machteld Venken

Introduction: Borderland Studies Meets Child Studies.

A European Encounter

Catherine Maurer \& Gabrielle Ripplinger

Destitute Children in Alsace from the Beginning of the

Twentieth Century to the End of the 1930s:

Orphan Care in Strasbourg, in between France and Germany

Ruth Leiserowitz

Childhood in the Memel Region

Julien Fuchs

Youth Movements in Alsace and the Issue of National Identity, 1918-1970 ......85

Beata Halicka

The Everyday Life of Children in Polish-German Borderlands

During the Early Postwar Period

Tobias Haimin Wung-Sung

'We Remain What We Are' Wir bleiben was wir sind?'

North Schleswig German Identities in Children's Education After 1945.

Andreas Fickers

Generational Conflicts, the Spirit of ' 68 and Cultural Emancipation in the

German Speaking Community of Belgium. A Historical Essay About the

'73 Generation

Deutsche Abstracts

Notes on Contributors

Index of Places 



\section{List of Figures, Illustrations and Maps}

Map 1: German Territorial Changes in the 20th Century.

Map 2: Alsace-Lorraine 1871-1918.

Map 3: The Memel Region in the Interwar Period.

Map 4: Poland's Border Shifts After the Second World War.

Map 5: Danish North Schleswig since 1920.

Map 6: The Border Regions After theTreaty of Versailles (1920).

Map 7: The Border Regions During the Second World War (1940-44).

Illustration 1: (cover image) 'It's chic to speak French'.

Illustration 2: A plan of the municipal orphanage, viewed from the front, in 1909.

Illustration 3: The veranda of a sanatorium and a back view of the municipal orphanage and of its veranda.

Illustration 4: The bathrooms of the orphanage.

Illustration 5: The orphanage Saint-Joseph in Mulhouse.

Illustration 6: The ancient orphanage of Colmar.

Illustration 7: Members of the local 'Bar Kochba' in 1937 on the sports field.

Illustration 8: Inaugural assembly of the Betar in Memel 1927.

Illustration 9: Cover of the first issue of the magazine Jeune Alsace.

Figure 1:Religion of girls admitted in the orphanage between 1904 and 1933.

Figure 2: Religion of boys admitted in the orphanage between 1904 and 1933. 


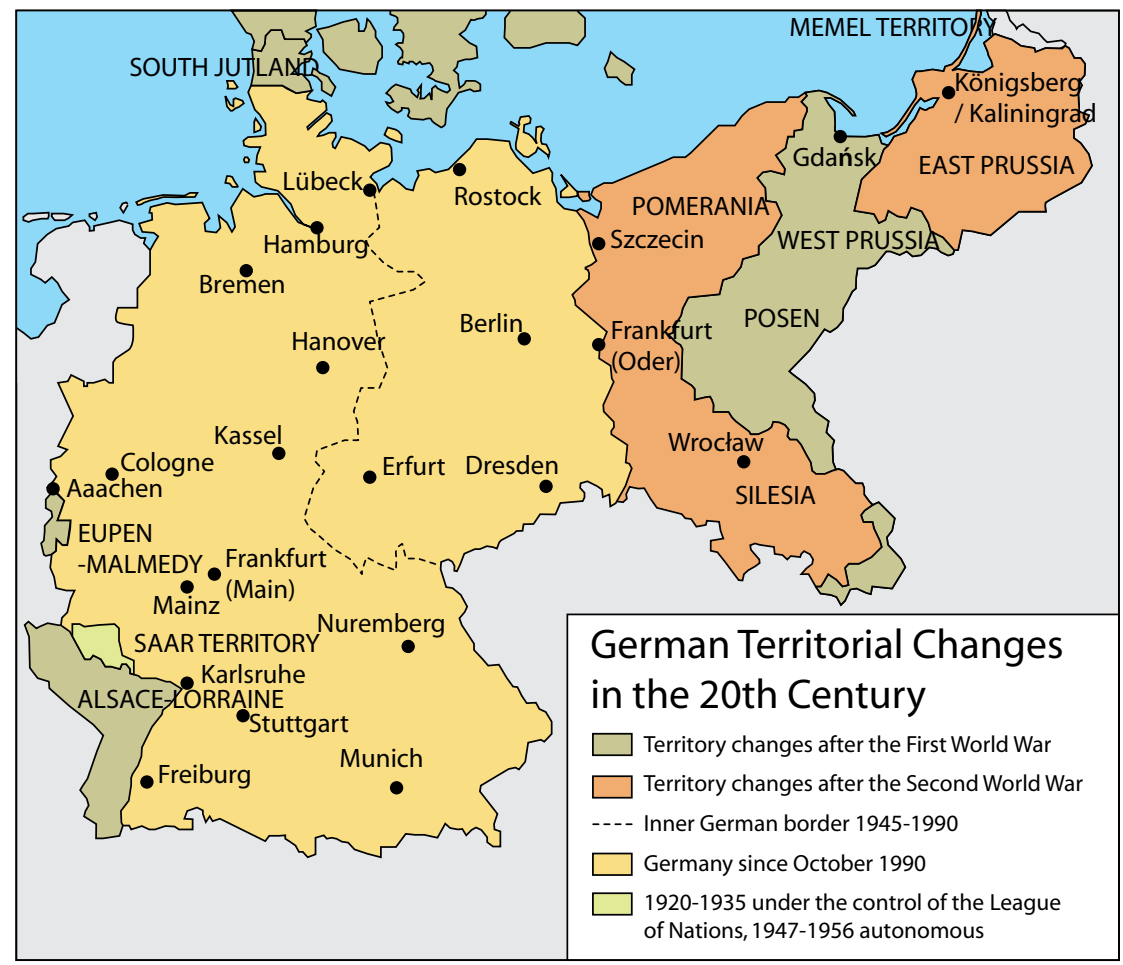

Map 1: German Territorial Changes in the 20th Century. 


\title{
Machteld Venken
}

\section{Introduction: Borderland Studies Meets Child Studies. A European Encounter ${ }^{1}$}

\begin{abstract}
With the demise of four multinational empires at the end of the First World War (Russian, German, Habsburg and Ottoman), nationalist forces all over Europe claimed the right to a territory for what they considered to be their own people. The peace treaties resulting from the Paris Peace Conference in 1919 caused a major redrawing of the map of Europe. As a result of the Treaty of Versailles, Germany handed over a considerable amount of its territory at its Western, Northern and, most significantly, Eastern borders, to neighbouring states. This edited volume focuses on the regions lying in what one could call a ring around Germany lost by Germany after the First World War. The European border regions of annexation, as I call them, switched their sovereignty as follows: Alsace-Lorraine became French, Eupen-Malmedy Belgian, North Schleswig Danish, various former Prussian Eastern provinces became Polish, the Hlučin region Czechoslovakian, and the Memel region Lithuanian. By setting up a historical comparison of the living conditions of children in European borderlands of annexation throughout the 20th Century, this edited volume provided the context for an encounter of a new combination of categories from different disciplines: Borderland Studies meets Child Studies.
\end{abstract}

Although the 20th century experienced a significant number of border changes in Europe and saw European nation-states substantially increasing their interest in children, Europe's borderland children remain under-researched. Starting from the research findings of borderland scholars, who found that borderlands were central sites of power struggle, and of childhood scholars, who delineated how precisely states expressed their plans in their programs for children, this edited volume provides a comparative analysis of the history of borderland children. The contributions revealed various new findings and a new hypothesis. More than their parents, it turned out, it was the children who were envisioned to play

1 I would like to express my gratitude to my colleagues in the Institute for Eastern European Studies at the University of Vienna, in particular to Agnieszka Pasieka and Philipp Ther, for formulating thoughtful remarks on an earlier version of this introduction. During the conference 'Growing Up in $20^{\text {th }}$ Century European Borderlands' I organised in Vienna in 2015, Tomasz Kamusella, Katherine Lebow and Benita Blessing provided the individual authors with useful comments. 
a crucial role in bringing about the peaceful Europe that representatives at international peace conferences had had in mind while changing the sovereignty of the borderlands these children inhabited. Each of the individual contributions showed the complexity of nationalisation within various, often previously undiscovered, spheres of borderland children's lives. They also deepened our insights into the dichotomy between the nationalist policies executed towards borderland children and the manifest non-national practices of these children that had been investigated by historians for schooling during the interwar period. They shed light on other aspects of interwar children's life-worlds, as well as on borderland nationalist education after the Second World War. Reading the contributions comparatively, one might hazard a new hypothesis. Despite the different imaginations of East and West that had influenced the decisions of peace negotiators after both World Wars, borderland children, in strikingly similar ways on the Eastern and Western halves of the European continent, came to invent creative practices that contributed to the creation of a much more socially cohesive Europe. This seems to indicate that a definition of Europeanisation should be sensitive to the specificity of various historical agents, including children, instead of simply being based on the discourse of those who held the reigns of power at a given time in the past.

\section{Borderland Studies}

Implying that history is national, historians for a long time regarded as axiomatic the homogeneity of nation-states. Studies in nationalisation, unravelling the intricacies of nation formation and stabilisation in core-areas of nation-states, have long been popular features of mainstream historiography. Nationalisation covers political and social attempts to get people to identify with the nation-state. In the case of affirmative articulation, the nation-state has been successful in forming its citizens. ${ }^{2}$ A nation-state offers an institutionalized set-up for people with shared values and ideas of order. ${ }^{3}$

Major border changes on the European continent (respectively the demise of the Cold War set-up following the collapse of communism, the Yugoslav wars, and the enlargement project of the European Union) have inspired historians to readdress or shift their lens of analysis to borders, the physical demarcation lines

2 Krishan Kumar, 'Nationalism and the Historians', in Gerard Delanty, Krishan Kumar, eds., 'The SAGE Handbook of Nations and Nationalism' (London: Sage, 2006), 7-20.

3 Dieter Langewiesche, 'Nation, Nationalismus, Nationalstaat in Deutschland und Europa' (München: C.H. Beck, 2000), 14. 
between nations. ${ }^{4}$ The recent strengthening of national borders as a response to wandering asylum seekers shows that the topic still lies at the heart of order and safety within Europe. National borders separate the territory of states, but also influence the lives of the people inhabiting borderlands.

Daphne Berdahl explained borders as 'symbols through which states, nations, and localities define themselves. They define at once territorial limits and sociocultural space. ${ }^{5}$ Whereas borders refer to lines of separations, borderlands encompass areas that come to be divided through the creation of borders. ${ }^{6}$ Peter Sahlins understood the French-Spanish border as a bridge between national and local ideologies. While appreciating the mutual influence the national and local ideologies had on each other, the author aimed to prove the ascendancy of national ideologies over local loyalties. ${ }^{7}$ Later work pointed to the limitations of nationalisation and the flexibility in identifications among borderland inhabitants. ${ }^{8}$ In what Philipp Ther has called Zwischenräume, i.e. linguistic, cultural, religious and/or ethic transition areas, historians have found much contesting going on between national movements, a fact which turned these regions, despite their peripheral location, into central sites of power struggle. ${ }^{9}$

4 Jörg Seifarth, Etienne François, Bernhard Struck, 'Grenzen und Grenzräume: Erfahrungen und Konstruktionen', in Jörg Seifarth, Etienne François, Bernhard Struck, eds., 'Die Grenze als Raum: Erfahrung und Konstruktion' (Frankfurt am Main: Campus Verlag, 2007), 7.

5 Daphne Berdahl, 'Where the World Ended: Re-Unification and Identity in the German Borderland' (Berkeley/Los Angeles: University of California Press: 1999), 3.

6 Libora Oates-Indruchová, Muriel Blaive (eds), 'Border Communities: Microstudies on Everyday Life, Politics and Memory in European Societies from 1945 to the Present', introduction to a special issue of Nationalities Papers, Volume 42, Issue 2, March 2014, 195.

7 Peter Sahlins, 'Boundaries: The Making of France and Spain in the Pyrenees' (Berkeley: University of California Press, 1989).

8 Robert Traba, 'Wschodniopruskość. Tożsamość regionalna i narodowa w kulturze politycznej Niemiec' (Poznań-Warschau: Wydawnictwo Poznańskiego Towarzystwa Przyjaciół Nauk, 2005), 279.

9 Philipp Ther, 'Sprachliche, kulturelle und ethnische „Zwischenräume“ als Zugang zu einer transnationalen Geschichte Europas', in Holm Sundhaussen, Philipp Ther, eds., 'Regionale Bewegungen und Regionalismen in europäischen Zwischenräumen seit der Mitte des 19. Jahrhunderts' (Marburg: Herder-Institut, 2003), XII; Tatiana Zhurzhenko, 'Borders and Memory', in Doris Wastl-Walter, eds.,'The Ashgate Research Companion to Border Studies' (Aldershot: Ashgate, 2010), 74. 
Under the influence of this cultural shift, scholars came to understand national appropriation as a construction, that is as experiencing the social world as differentiated between 'us' and 'them', in this way withdrawing from primordialist interpretations that claim identifications as innate characteristics. ${ }^{10}$ While researching 'inventions of traditions ${ }^{11}$ in borderlands, however, scholars often discovered inhabitants who at moments happened to have distanced themselves from any nation's appeal, while at other moments moved back and forth (possibly multiple times) in their notions about their rights and duties towards their nation-state. ${ }^{12}$ Although it is the ambition of nation-states to hold a strong position in policy-making in borderlands, it is indeed social actors who make their own use of policies.

Historians used the methods of the Alltagsgeschichte (or everyday life history) in order to unravel how political ideas interact in the lives of non-hegemonic inhabitants of borderlands. ${ }^{13}$ Aiming to shed light on the way local people appropriated, changed or refuted such ideas in their daily life practices, authors are growing away from using a solely top-down approach, and now also approach their microstudies from a bottom-up perspective. ${ }^{14}$ Practices, i.e. repetitions in everyday routines, articulate the relationship between individuals and their environment, and provide experiences with one or multiple means of appropriation. ${ }^{15}$

10 Rogers Brubaker, 'Ethnicity, Migration, and Statehood in Post-Cold War Europe', in Michel Seymore, eds., 'The Fate of the Nation-State' (McGill: Queen's University Press, 2004), 358.

11 Terence Ranger, Eric Hobsbawm et al., 'The Invention of Tradition' (Cambridge: Cambridge University Press, 2003).

12 Bernard Linek, 'Einleitung', in Kai Struve, Bernard Linek, eds., 'Nationalismus und nationale Identität in Ostmitteleuropa im 19. und 20. Jahrhundert' (Marburg: Herder Institut, 2000), 6.

13 Muriel Blaive, Libora Oates-Indruchová, 'Introduction: Border communities: microstudies on everyday life, politics and memory in European Societies from 1945 to the present', Nationalities Papers 42, 2 (2014), 195.

14 Libora Oates-Indruchová, Wolfgang Mueller, 'Space, Borders, and Borderlands: Global and East European Approaches in Historiography', Österreichische Zeitschrift für Politikwissenschaft 42, 1 (2013), 44.

15 Alf Lüdtke, 'Einleitung: Was ist und wer treibt Alltagsgeschichte?', in Alf Lüdtke, eds., 'Zur Rekonstruktion historischer Erfahrungen und Lebenswelten' (Frankfurt am Main: Campus Verlag, 1989), 11-12; Christian Pletzing, Peter Oliver Loew, Thomas Serrier, 'Zwischen Enteignung und Aneignung: Geschichte und Geschichten in den "Zwischenräumen Mitteleuropas", in Christian Pletzing, Peter Oliver Loew, Thomas Serrier, eds., 'Wiedergewonnene Geschichte. Zur Aneignung von Vergangenheit in den Zwischenräumen Mitteleuropas' (Wiesbaden: Harrassowitz, 2006), 12. 
While investigating how inhabitants with different national and local identifications lived in each others' vicinity and learned how to cooperate with each other, ${ }^{16}$ historians like Tara Zahra and Tomasz Kamusella noticed a major demarcation line not between two juxtaposed competing nationalisms, but between the national versus non-national attitude of borderland inhabitants. In an attempt to research historically those who would have been deaf to the appeals of nationalism, they came up with new concepts. Tara Zahra tested out national indifference as a category of analysis in her study on the Bohemian lands, while Tomasz Kamusella, in his work on the German-Polish borderlands of Upper Silesia, favoured the concept of 'non-national groups' because he considers its meaning deprived of a teleology. ${ }^{17}$ Notwithstanding his, by definition, dichotomous view of the past, Tomasz Kamusella indicated the flexibility of nationalist ideologies and non-national practices. While speaking about the early $19^{\text {th }}$ Century in Central Europe, he came to conclude: 'nationally teleological thinking was increasingly a part of the socio-political reality that the 'nationally indifferent' inhabited and that it gradually more forcefully structured their lives. ${ }^{18}$ Anthropologists like Pamela Ballinger addressed 'the intertwined history of purity and hybridity discourses' earlier and encouraged an unravelling of 'the historical dialogue and interpenetration of languages of purity/homogeneity and hybridity.' ${ }^{19}$

Such an approach also requires us to reflect on the relationship between nationalism and regionalism. As both are inherently modern phenomena, contrary to what one might think, they are not competing or mutually exclusive concepts. ${ }^{20}$ In the interwar period, for example, authorities throughout Europe saw in regionalism a

16 Omer Bartov, Eric D. Weitz, 'Coexistence and Violence in the German, Habsburg, Russian, and Ottoman Borderlands', in 'Shatterzone of Empires' (Bloomington: Indiana University Press, 2013), 1.

17 Tara Zahra, 'Kidnapped Souls. National Indifference and the Battle for Children in the Bohemian Lands, 1900-1948' (Sage: Cornell University Press, 2008); Tomasz Kamusella, 'Upper Silesia in modern Central Europe. On the significance of the non-national/ a-national in the age of nations', in Tomasz Kamusella, James Bjork, Timothy Wilson, Anna Novikov, eds., 'Creating Nationality in Central Europe, 1880-1950: Modernity, Violence and (Be) Longing in Upper Silesia' (London: Routledge, 2016), 15.

18 Tomasz Kamusella, The Politics of Language and Nationalism in Modern Central Europe, Houndsmill, Palgrave, 2009, 15.

19 Pamela Ballinger, “Authentic Hybrids" in the Balkan Borderlands', Current Anthropology: 45, 1 (2004), 48.

20 Celia Applegate, 'A Nation of Provincials. The German Idea of Heimat' (Berkeley: University of California Press, 1990). 
force capable of buttressing their national policies. ${ }^{21}$ This was especially true in borderlands where national sovereignty had changed. In such cases, officials were well aware that regionalism, because inhabitants granted it cognitive affinity, enjoyed more claim than nations, which were imagined as bigger communities. ${ }^{22}$ An example of this would be Polish Upper Silesia, where the frequent border changes had undermined the stability of any sense of national belonging and opened the path to other orientations. The various regionalisms at work here, such as the Heimat movement and the fostering of what was seen as the Silesian language, were nevertheless supported by nationalist cultural claims, either from the Weimar Republic, or the Polish Republic. Notwithstanding the autonomous status the region enjoyed, political regionalist tendencies never operated outside of nationalist frameworks and did not aspire to take over sovereignty. ${ }^{23}$

\section{Child Studies}

The field of child studies is increasingly valued for offering an interesting lens through which to view our knowledge of the past, as states tend to define their plans very clearly in their policies towards their future citizens. ${ }^{24}$ This young but established field of historical enquiry encourages us to learn about the goals of societies through the prism of child policies and children's experiences. ${ }^{25}$

Children have traditionally been presented as figures on the margins of history, and research on children has mainly focused on what adults said about children in various child policy programmes or child institutions. Because the 'Century of the Child ${ }^{26}$ saw an 'unprecedented expansion of state activity' on child-rearing, studies in childhood often start from the viewpoint of a nation-state designing

21 Philipp Ther, 'Zwischenräume', XVI.

22 Benedict Anderson, 'Imagined Communities. Reflections on the Origin and Spread of Nationalism' (London: Verso, 2006).

23 Peter Polak-Springer, 'Recovery Territory. A German-Polish Conflict over Land and Culture, 1919-1989' (New York: Berghahn Books, 2015), 48.

24 Paula S. Fass, 'Introduction: Is There a Story in the History of Childhood?', in Paula S. Fass, eds., 'The Routledge History of Childhood in the Western World' (London: Routledge, 2013), 1-14; Martha Saxton, 'Introduction into the First Volume of the Journal of Childhood and Youth', in Heidi Morrison, eds., 'The Global History of Childhood Reader' (New York: Routledge, 2012), 103-104.

25 Paula S. Fass, 'Encylopedia of Children and Childhood' (London: Macmillan Reference, 2004).

26 This phrase was first expressed by the Swedish feminist Ellen Key, who at the beginning of the $20^{\text {th }}$ Century, hoped parents would devote more time in order to bring up their 
child policies in its capital to serve children on the whole of its territory. ${ }^{27} \mathrm{His}-$ torical pedagogy is a well-developed research field in Europe and studies about children's rights and youth movements using a top-down national perspective are available for almost all European countries. The typical kind of conflicts addressed in such studies are related to clashes between state-building processes, based on a traditional notion of the nation's elite, the emancipation of the nation's masses through a prohibition on child labour, the struggle against child mortality, and the introduction of compulsory education. ${ }^{28}$

Since the 1960s, however, children have also been regarded as important historical co-creators of everyday life. The individual agency of children is far more difficult to grasp since a child is not thought to be rational, which, according to Mary Jo Maynes, is still at the heart of historians' idea of a social actor. ${ }^{29}$ The cognitive, linguistic and emotional boundaries of children have often been used as an argument against exploring the kind of agency that children possessed at various moments throughout history. ${ }^{30}$ Perhaps, however, it is time we evaluated child testimonies 'with the same critical scepticism and respect' as other sources, rather than dismissing them. ${ }^{31}$ Historians have already learned from psychological research on child court witnesses the importance of not overlooking children's

children in sheltered environments. See also: Ellen Key, 'The Century of the Child' (New York, 1909).

27 Dirk Schumann et al., 'Raising Citizens in the "Century of the Child". The United States and German Central Europe in Comparative Perspective' (New York: Berghahn Books, 2010).

28 Pier Paolo Viazzo, Carlo A. Corsini, 'The Decline of Infant and Child Mortality. The European Experience: 1750-1990' (Boston: Martinus Nijhoff Publishers, 1997); JeanFrançois Chanet, 'L'école républicaine et les petites patries' (Paris: Aubier, 1996); Jeffrey Tyssens, 'Om de schone ziel van't kind... Het onderwijsconflict als een breuklijn in de Belgische politiek' (Gent: Provinciebestuur Oost-Vlaanderen and het Liberaal Archief, 1998), 216; Jane Humphries, 'Childhood and Child Labour in the British Industrial Revolution (Cambridge: Cambridge University Press, 2010).

29 Saskia Handro, 'Zwischen Identitätsstiftung und historischem Verstehen: Kriegskindheit in deutsch-deutschen Schulgeschichtsbüchern', in Hans H. Ewers, Jana Mikota, Jürgen Reulecke, Jürgen Zinnecker, eds., 'Erinnerungen an Kriegskindheiten: Erfahrungsräume, Erinnerungskultur und Geschichtspolitik unter sozial- und kulturwissenschaftlicher Perspektive' (Weinheim: Juventa-Verlag, 2006), 233-261.

30 Peter N. Stearns, 'Challenges in the History of Childhood', The Journal of the History of Childhood 1 (2008), 35-42.

31 Benita Blessing,'The Antifascist Classroom: Denazification in Soviet-Occupied Germany, 1945-1949' (New York: Palgrave Macmillan, 2006). 
accounts, but evaluating their strengths and weaknesses. Studies that centralise child sources such as diaries, school essays, drawings and pictures have convincingly shown that shortcomings in children's use of language or references to time and place may not be valid reasons for discarding children's descriptions of interpersonal relations and everyday life conditions as contributions to the reconstruction of a fuller picture of the past. ${ }^{32}$ Children indeed not only experience situations differently from adults, they often also face other horizons of experience. Young children are, for example, less politically informed and, as a result, do not understand or share the opinions of adults.

There are clear methodological challenges in finding out how children viewed their treatment by adults, how they articulated this experience in their own practices, and how they recall it in sources. Along with using the scarce so-called ego documents children left in the past, historians have recently opted for the oral history method. There is a consensus within the oral history discipline that our knowledge about the past can only be made available through narratives giving meaning to the biographical self at the moment the interview is conducted..$^{33}$ Although research findings based on child ego documents and newly created testimonies do not always make it possible to come to far-reaching conclusions about past societal processes, they allow for the inclusion of different voices and add to a more complex understanding of everyday life in $20^{\text {th }}$ Century Europe. ${ }^{34}$

A key question, deriving from an increased focus on child experiences, is how to define children. This is especially true of the $20^{\text {th }}$ Century when the period of childhood was elongated, thanks to children spending more time in school, entering the labour market later, and youth organisations flourishing. Whereas scholars have traditionally followed the logic of the systems they were studying, in which schoolchildren are defined according to rules concerning obligatory

32 Nicholas Stargardt, 'Children's Art of the Holocaust', Past and Present 161, 1 (1998), 191-235; Margaret Peacock, 'Broadcasting Benevolence: Images of the Child in American, Soviet and NLF Propaganda in Vietnam, 1964-1973', The Journal of History of Childhood and Youth 3 (2010), 15-38; Lawrence Graver, 'An Obsession with Anne Frank: Meyer Levin and the Diary' (Berkeley: University of California Press, 1997).

33 Machteld Venken, 'Straddling the Iron Curtain? Immigrants, Immigrant Organisations, War Memories' (Frankfurt: Peter Lang, 2011).

34 For an example see Machteld Venken, 'Child forced labour: an analysis of ego documents throughout time', European Review of History - Revue européenne d'histoire 22,2 (2015), 368-388. 
school attendance valid at the time, ${ }^{35}$ others delineate age cohorts and follow child experiences for a time-slot they consider of political relevance, such as youth in Communist Poland. ${ }^{36} \mathrm{~A}$ third research line investigates the extent to which children shared the spirit of a time and enjoyed a generational experience that influenced their behaviour also later in life. ${ }^{37}$

While scholars have demonstrated the importance of turning age into a central category of analysis, they are also finally aware that it has taken some of their attention away from another major category, namely gender. Boys and girls were indeed objects and subjects of history in different ways. ${ }^{38}$ As much as childhood policies reflected other ideals of nationalisation for both sexes, so too are the ways such policies were experienced and articulated into speech gender-specific.

\section{Europeanisation?}

At the end of both the First and Second World Wars, imagined visions of Europe found themselves in the heads of decision-makers responsible for reshaping borders in Europe. In the last year of his life, Georges Clemenceau (1841-1929) reflected on the decisions he had made a decade earlier while representing France at the Paris Peace Negotiations in 1919, where after the defeat of Germany the map of Europe was redrawn. He defended the Treaty of Versailles as 'the greatest victory of all' because it had realised a 'peaceful Europe founded on right. ${ }^{39}$ Clemenceau was attacked by nationalists in France, who believed that the Rhineland, a region that belonged to the interwar German state and held borders with France, should have simply been annexed following the First World War, instead of being only temporarily military occupied. In the Anglo-Saxon world, moreover, politicians grumbled that Clemenceau and representatives of the other victorious Great

35 See for example Krzysztof Kosiński, ‘O nową mentalność: życie codzienne w szkołach 1945-1956' (Warschau: Trio, 2000).

36 Hanna Świda-Ziemba, 'Młodzież PRL. Potrety pokoleń w kontekście historii (Wydawnictwo Literackie Krakow, 2011).

37 Dorothee Wierling, 'Geboren im Jahr Eins: der Jahrgang 1949 in der DDR: Versuch einer Kollektivbiographie’ (Berlin: Links, 2002).

38 Yulia Gradskova, Helene Carlbäck, Zhanna Kravchenko, 'Introduction', in Yulia Gradskova, Helene Carlbäck, Zhanna Kravchenko, eds.,'And they Lived Happily Ever After. Norms and Everyday Practices of Family and Parenthood in Russia and Eastern Europe' (Budapest: CEU Press, 2012), 1-22.

39 Georges Clemenceau, 'Grandeur and Misery of Victory' (New York: Harcourt, Brace, 1930), 166-77, 185-87, 198-201, 205-07, 379, 386-88. 
Powers had not shared Woodrow Wilson's idea of installing a supranational order based on liberal principles, preferring instead to attain national security.

Not long before the end of the Second World War, the leaders of the United States, Great Britain and the Soviet Union gathered in Yalta in order to consider the rehabilitation of pre-war European nation states. Upon his return to the United States, Franklin Roosevelt argued that, following the signing of the Declaration of a Liberated Europe, he came 'from the Crimea with a firm belief that we have made a start on the road to a world of peace. ${ }^{40}$ One of the agreements had been to shift the Polish border westwards to the Curzon Line. Soon after the Second World War had come to an end, it turned out Stalin would violate the conditions of the Treaty, by, inter alia, preventing true free elections to take place in postwar Poland.

The discourse of a peaceful Europe had already started to function as an impulse for increased cooperation and an understanding of common belonging in the beginning of the modern period when, because of frequent religious conflicts, the trope of Christianity had lost much of its appeal. ${ }^{41}$ The territorial changes introduced in the international treaties concluded after the First and Second World Wars affected the lives of many people, especially of those living in borderlands changing sovereignty. Does this observation enable us to say that $20^{\text {th }}$ century borderland inhabitants experienced Europeanisation? Let us have a look at two scientific approaches towards Europeanisation.

According to the first approach, Europeanisation is used as a way to correct the imbalanced knowledge we possess of the characteristics of nationalisation on the European continent. Having noticed that Western European historiography was practiced by scholars without knowledge of East Central European languages, and that the research topics of East Central European historiographers focus solely on the East Central European territory, Michael Geyer made a plea for what he called the Europeanisation of European history. ${ }^{42}$ Larry Wolff places the roots for drawing a mental border through Europe in order to separate what becomes constructed as a backward and peripheral Eastern part from a more prosperous

40 Joanna Potts, Simon Berthon, 'Warlords: An Extraordinary Re-creation of World War II through the Eyes and Minds of Hitler, Churchill, Roosevelt, and Stalin' (Cambridge: Da Capo Press, 2007, 291.

41 Wolfgang Schmale, 'Geschichte Europas' (Stuttgart: UTB, 2001).

42 Michael Geyer, 'Historical Fiction of Anatomy and the Europeanization of National History', Central European History 22(3-4) (1989), 334. 
and civilised Western part not, as it is commonly believed, in the early days of the Cold War, but already in the late 18th Century. ${ }^{43}$

Going beyond this binary view, Ulrike von Hirschhausen and Jörn Leonhard compared nationalisms in Western and Eastern Europe. They eroded the predominant importance of what long has been seen as the different essence of German nationalism (based on the Herderian concept of language), and, for example, French nationalism (based on the revolutionary ideas of citizenry). Through comparing nationalisms in various countries, they found out that there is not something like a 'uniform big thing' lying behind a concept legitimising a nation, but a 'pluralism of competing interpretations' dependent upon, inter alia, state structures and societal dynamics. ${ }^{44}$ In demonstrating further how ideological and religious segmentations were paramount in Eastern Europe ${ }^{45}$ and how symbols and rituals enabled the inclusion of competing interpretations of nationalism in nationalist discourses, ${ }^{46}$ the authors contribute to a breaking down of juxtaposed constructions such as Western civic nationalism versus Eastern ethnic nationalism. ${ }^{47}$

Due to the fact that most studies on nationalism in borderlands are limited to a region situated on the borders of neighbouring nation-states, historians have already proposed researching similarities and differences between border regions. In approaching Europe as a collage of many interdependent spaces, Christian Pletzing and others, for example, combine concepts used in Borderland Studies with those of practice in research on Europeanisation. ${ }^{48}$ Since such comparisons

43 Larry Wolff, 'Inventing Eastern Europe. The Map of Civilization on the Mind of the Enlightenment' (Stanford: Stanford University Press, 1994), 4-6.

44 Ulrike von Hirschhausen, Jörn Leonhard, 'Europäische Nationalismen im WestOst-Vergleich: Von der Typologie zur Differenzbestimmung', in Ulrike von Hirschhausen, Jörn Leonhard, eds., 'Nationalismen in Europa. West- und Osteuropa im Vergleich' (Göttingen: Wallstein, 2001), 44.

45 Ibid., 31.

46 Ibid., 38

47 Stephanie Zloch, 'Gibt es einen "osteuropäischen Nationalismus”? Anmerkungen zur Persistenz einer historischen Interpretationsfigur', in Miloš Řezník, Pavel Kolář, 'Historische Nationsforschung im geteilten Europa 1945-1989' (Köln, SH-Verlag, 2012), 51.

48 Christian Pletzing, Peter Oliver Loew, Thomas Serrier, 'Zwischen Enteignung und Aneignung: Geschichte und Geschichten in den "Zwischenräumen Mitteleuropas", in Christian Pletzing, Peter Oliver Loew, Thomas Serrier, eds., 'Wiedergewonnene Geschichte. Zur Aneignung von Vergangenheit in den Zwischenräumen Mitteleuropas' (Wiesbaden: Harrassowitz, 2006), 9. 
generally stayed within the framework of the big European nations ${ }^{49}$ and within their mental map of Europe ${ }^{50}$ there remains a need for elaborated empirical historical comparisons at a regional and local level, also in less studied Western and East Central European areas. Some recent publications have called the supremacy of the 'communist versus capitalist rivalry in Cold War bordering' into question and demonstrate how all European political authorities had nationalising purposes in mind while designing policies for their borderlands. ${ }^{51}$

With much of the research on Europe throughout the $20^{\text {th }}$ Century still being concentrated on smaller time periods, Europeanisation can also encourage us to search for continuities and changes throughout the longer $20^{\text {th }}$ Century. ${ }^{52}$ Such an approach goes against the trend of seeing the emergence and functioning of an enlarging European Union as a teleological process, and provides us with the image of what Normal Davies has called a 'tidal' Europe, a Europe with an everchanging shore and sea in terms of territory, as well as of political, economic and social ambitions. ${ }^{53}$

It might also be appropriate, as well as more ambitious, as Ulrike von Hirschhausen and Kiran Klaus Patel argue, to utilise the concept of Europeanisation in the $20^{\text {th }}$ Century 'not as a fact, but as a thesis to be tested..${ }^{54}$ Europeanisation then is defined as 'a process (or processes) that happened' or 'a discourse which, by influencing the way in which actors have seen the world, has had an impact on the shape of the European 20th Century. ${ }^{55}$ In order to speak about

49 Jörg Seifarth, Etienne François, Bernhard Struck, ‘Grenzen und Grenzräume: Erfahrungen und Konstruktionen', in Jörg Seifarth, Etienne François, Bernhard Struck, eds., 'Die Grenze als Raum: Erfahrung und Konstruktion' (Frankfurt am Main: Campus Verlag, 2007), 7-32.

50 Hans Lemberg, 'Grenzen und Minderheiten im östlichen Mitteleuropa - Genese und Wechselwirkungen', in Hans Lemberg, eds., 'Grenzen in Ostmitteleuropa im 19. und 20. Jahrhundert. Aktuelle Forschungsprobleme’ (Marburg: Herder-Institut, 2000), 159-182.

51 Muriel Blaive, Libora Oates-Indruchová, 'Introduction: Border communities: microstudies on everyday life, politics and memory in European Societies from 1945 to the present', Nationalities Papers 42, 2 (2014), 197.

52 Ulrike von Hirschhausen, Kiran Klaus Patel, 'Europeanization in History: An Introduction', in Martin Conway, Kiran Klaus Patel, eds., 'Europeanization in the Twentieth Century: Historical Approaches' (Basingstoke: Palgrave Macmillan, 2010), 2.

53 Norman Davies, 'Europe: A History' (Oxford: Oxford University Press, 1996), 9.

54 Ulrike von Hirschhausen, Kiran Klaus Patel, 'Europeanization in History: An Introduction', in Martin Conway, Kiran Klaus Patel, eds., 'Europeanization in the Twentieth Century: Historical Approaches' (Basingstoke: Palgrave Macmillan, 2010), 2.

55 Ibid., 16. 
Europeanisation, the authors find it essential to establish whether or not historical actors came to define the processed they experienced as European. In the case of the territorial changes Europe experienced as a result of international peace talks, it is hard to answer that question. At the decision tables, different ideas on how a peaceful Europe could look like played a role, but so did other, more nationally minded views. Rather than being claimed as a successful product of Europeanisation, the peace negotiation outcomes have always been subject to harsh critique from both people in favour of more Europeanisation and those wanting less.

By means of this edited volume, I came to search for the relationship between the polemicised Europeanising character of the peace conferences and the ways in which borderland children affected by the consequent border shifts affirmed, rejected or redefined their meaning. The late Tony Judt did not interpret the $20^{\text {th }}$ Century primarily as a clash of various (whether democratic, fascist, or communist) ideologies, but saw it characterised by the rise of state involvement in all European countries. ${ }^{56}$ Scholars' interest in researching state involvement in children together with the process of Europeanisation dates from more recently. The relationship between the state and the family with regards to child-rearing is often only discussed within a Western European context. Such an approach is either motivated by the fact that state involvement in Eastern and Southern Europe was patchy and thin on the ground for a long time, or because socialism is believed to have produced a particular type of family. Machteld Venken and Maren Röger pointed out, however, that it would be misleading to suggest that the divide in Europe regarding family values was due to the fact that communist authorities were only able to successfully imbue children with their ideology thanks to the reduced influence of the family in this part of Europe. The nuclear family, for example, was just as common in East and Central European societies as in Western ones. ${ }^{57}$ Similarly, nationalising children was a phenomenon characterising all European political regimes, whether democratic, authoritarian or dictatorial. ${ }^{58}$ Such an insight indicates that a research focus on a group

56 Tony Judt, Timothy Snyder,'Thinking the Twentieth Century' (London: Vintage Books, 2013), 386.

57 Machteld Venken, Maren Röger, 'Growing Up in the Shadow of the Second World War: European Perspectives', in Maren Röger, Machteld Venken (eds.) 'Growing Up in the Shadow of the Second World War. European Perspectives', European Review of History - Revue européenne d'histoire, 22, 2 (2015), 206.

58 Klaus Schleicher, 'Nationalism in Education' (Frankfurt am Main: Peter Lang, 1993). 
that nation-states considered to have been of pivotal importance has significant comparative potential.

\section{An integrated approach}

The case study carried out in this edited volume offered a selection of borderlands from both the Eastern and Western part of the European continent whose sovereignty switched as a consequence of international beliefs about the interdependency of safeguarding peace in Europe and changing its borders. I chose to use the overall concept of borderlands to embrace all of the German territories that were contested during the First and Second World Wars, and whose sovereignty shifted after those wars came to an end. The reader needs to keep in mind that, whereas some of these borderlands already had a long history of border shifting on the verge of the First World War I (such as Upper Silesia), other territorial entities were only called into being through the Treaty of Versailles (such as Eupen-Malmedy and the Memel region).

After the First World War, the complex negotiations about the shape of the new independent Polish state, which had previously been divided among the Habsburg, Prussian and Russian Empire, yielded to an international policy on the protection of minorities. The ideas of nationalists striving for the primacy of one religion, one culture, and one language clashed with the presence of the many inhabitants whose characteristics evidently varied. Poland was the first of a list of states in Central and Eastern Europe for which the acceptance of a minority treaty was made a condition for its recognition as a state on an international level. Whereas the Great Powers had already in the $19^{\text {th }}$ Century required new independent states to guarantee religious rights, the League of Nations now stood for a guarantee of 'national' rights for whole minority groups. ${ }^{59}$ In the interwar years, ethnic or linguistic minorities were to coexist within nation-states. ${ }^{60}$ Although the unmixing of populations, as it was formulated in the Treaty of Lausanne (foreseeing the population exchange of borderland inhabitants living in Greece and Turkey) was only presented as an ultimate solution for the stabilization of peace in Europe, some practices in the European border regions of annexation already pointed out that minorities, and not nation-states, came to be seen as endangering the

59 Mark Mazower, 'Minorities and the League of Nations in Interwar Europe', Daedalus 126, 2 (1997), 51.

60 Hans Lemberg, 'Grenzen und Minderheiten im östlichen Mitteleuropa - Genese und Wechselwirkungen', in Hans Lemberg, eds., 'Grenzen in Ostmitteleuropa im 19. und 20. Jahrhundert. Aktuelle Forschungsprobleme' (Marburg: Herder-Institut, 2000), 168, 179. 
stabilization of order. ${ }^{61}$ In 1919, France violated the conditions of the Treaty of Versailles by cleansing Alsace-Lorraine of about 150,000 inhabitants of German and Austrian descent, and in 1922, following the division of Upper Silesia, around 200,000 inhabitants opted to cross the border and settle in either the Polish or German part of the region instead. ${ }^{62}$

Yet far from holding a universal character, the minority rights designed at French negotiation tables were notably paternalistic. Although it affected the majority of the minorities created by the border changes after World War I (i.e. those living in Central and Eastern Europe), Western European states did not have to adhere to any international supervision over the way they treated their minorities. The whole international set-up had therefore something of a civilisation mission for the Eastern part of the European continent, which turned out all the more problematic when one of these Western states, Germany, ostensibly started to include anti-Semitism into its state policies and refuted the national categorisation of its neighbours by aspiring to the unification of all the people it considered of German blood into one empire.

The way interwar European nationalisms affected policies for children in borderlands of annexation has already received some scholarly attention. Most noticeable in this respect is an international comparison of educational policies among non-dominant ethnic groups throughout Europe. Andreas Kazamias and others came to the conclusion that whereas various national authorities considered schools the main vehicle to integrate minorities and realise the homogeneous nation states they had in mind, the results of their efforts were at the very best only marginal, and often did not meet their objectives at all, either because minorities wanted these schools to play a role in their political emancipation, or because people appeared nationally indifferent. ${ }^{63}$ Publications focusing on the

61 Philipp Ther, 'The Dark Side of Nation-States: Ethnic Cleansing in Modern Europe' (New York: Berghahn Books, 2014), 419; Hans Lemberg, 'Grenzen und Minderheiten im östlichen Mitteleuropa - Genese und Wechselwirkungen', in Hans Lemberg, eds., 'Grenzen in Ostmitteleuropa im 19. und 20. Jahrhundert. Aktuelle Forschungsprobleme' (Marburg: Herder-Institut, 2000), 169.

62 Philipp Ther, 'The Dark Side of Nation-States', 137, 144; For a comment on the failed implementation see Vladimir Solonari, 'Book Reviews 2015', Slavic Review 74, 2 (2015), 372.

63 Andreas Kazamias, Knut Eriksen, Robin Okey, Janusz Tomiak, 'Governments and the Education of Non-Dominant Ethnic Groups in Comparative Perspective', in Andreas Kazamias, Knut Eriksen, Robin Okey, Janusz Tomiak, eds., 'Schooling, educational policy and ethnic identity: Vol. 1: Comparative studies on governments and nondominant ethnic groups in Europe, 1850-1940' (New York: New York University 
education of one minority group within one border region serve to support the observation that borderland pupils were objects of nationalisation policies, who were predicted to homogenise their community and the mainland and ensure the stability of the national borders. ${ }^{64}$ Recent historical research has engaged in a widening of aspects of children's life-worlds, such as leisure time. ${ }^{65}$ Some researchers have even explored the extent to which children enrolled in borderland youth organisations absorbed nationalising policies and articulated them in their life practices as subjects. ${ }^{66}$ The three contributions shedding light on the time period between the First and Second World Wars included in this edited volume need to be placed within this newest research trend.

In the first contribution of this volume, Maurer and Ripplinger looked at the situation of unfortunate children in the French-German borderlands during the first half of the $20^{\text {th }}$ Century. They showed how the Alsace region functioned as a laboratory where intensive experiments were carried out concerning how orphans should be taken care of. At the centre of their analysis was the Strasbourg orphanage, which developed during the period when the city first belonged to France (1681-1870), and continued functioning after the city switched to German sovereignty (1870-1918), and later again to French rule (1919-1940). While

Press, 1991), 390, 410, 415. For the concept of national indifference see Tara Zahra, 'Imagined Noncommunities: National Indifference as a Category of Analysis', Slavic Review 69, 1 (2010), 93-119.

64 Ingo Eser, 'Volk, Staat, Gott! Die Deutsche Minderheit in Polen und ihr Schulwesen 1918-1939' (Wiesbaden: Otto Harrassowitz, 2010); Carlo Lejeune, 'Tafel, Griffel, Rutenstock. 150 Jahre Eifeler Volksschulleben.' E. Volksschule: Warlich, 1989), 227-242; Erik Nørr, 'Nationalpolitik og skolebyggeri. Det hemmelige statstilskud til gennemførelsen af folkeskoleloven i Sønderjylland 1937-1970', Sønderjyske Årbøger (2014), 235-287.

65 Nina Jacobsen, Tysk nazistisk ungdomsarbejde i Nordslesvig 1933-1945, Sønderjyske Årbøger (1996), 195-222).

66 Jürgen Zinnecker, 'Soziologie der Kindheit oder Sozialisation des Kindes? Überlegungen zu einem aktuellen Paradigmenstreit', in Hans Rudolf, Leu Michael-Sebastian Honig, Ursula Nissen, eds., 'Kinder und Kindheit. Soziokulturelle Muster - sozialisationstheoretische Perspektiven' (Weinheim und München: Juventa-Verlag, 1996), 31; Herbert Ruland, „Stets für das Deutschtum eingetreten“ oder „Wie aus Eupener 'Volkstumskämpfern' der Zwischenkriegszeit Bürger der Bundesrepublik Deutschland wurden“" Biographische Notizen zu Bernhard und Billy Bredohl, Josef Thielen und Mine Cremer-Thielen', in Christoph Brüll et al., eds., 'Eine ostbelgische „Stunde Null“? Eliten aus Eupen-Malmedy vor und nach 1944: Annalen des Symposiums im Staatsarchiv in Eupen am 15. September 2012' (Brüssel: Generalstaatsarchiv, 2012), 29. 
comparing care for Alsatian orphans with the way it was organized in other places in both France and Germany, the authors revealed several specificities. Because French legislation about the secularism of childcare had been developed when the Alsace region belonged to the German Empire, when Alsace joined the French Republic, the orphanage was still managed by Catholic nuns (the Soeurs de la Charite de la Strasbourg). By the end of the 1920s, however, they had to step back and could only fulfil an assisting role comparable to those elsewhere in France. Overall, the authors found much similarity in the way German and French nationalists expressed their ideas, but detected the horizon of thinking regarding local caregivers and orphans to be mainly oriented towards what the authors call the small Alsatian homeland. Whereas Alsatian regional identities were strong enough to be fought for both by French and German nationalists, they had no real chance to take over sovereignty. ${ }^{67}$

In the second text, Ruth Leiserowitz mapped out interwar child experiences in the Memel region, a piece of land that was part of Germany until the end of the First World War, after which it was granted autonomous status within the new independent Lithuanian state. The author's thorough search for ego documents of children enabled her to reconstruct the life-worlds of children. Her main conclusion is that whereas structures set up for children, such as schools and organised leisure time activities, initially allowed for dialogues across ethnic and nationalist lines, they became more separatist throughout the 1930s. Leiserowitz's analysis of Jewish children offered a good example of this. Stimulated by the Lithuanian government and attracted by economic opportunities in the port city of Memel (nowadays Klaipeda), Jewish settlers migrated to the border region in large numbers. Their children visited schools in German or Lithuanian, and parents made that decision based more on the availability of schools in their vicinity than on their political preferences. Only in 1936, when national socialist ideology had begun to penetrate school rhetoric, was it felt necessary to set up a private Jewish primary school. Children in cities, moreover, were much less exposed to such intensified political polarisation than children living in the countryside, because school authorities kept their pupils away from political hot topics and prevented secondary schools from becoming bastions of nationalist indoctrination.

Over a much greater timespan (1918-1970), Julien Fuchs demonstrated how the idea of a nation was constructed within Alsatian youth movements. The author delineated their evolution in five periods of time, thereby offering

67 Philipp Ther, 'Zwischenräume', XXI. 
landmarks of development that, due to regional specificities, differ from those characterising youth movements in the rest of France and Germany. In all, Alsatian youth movements gradually moved closer to the French State over the years. Fuchs' contribution shows that the regionally specific way in which Alsatian youth movements operated did not yield to the establishment of particularisms. The deeply interwoven patriotic, religious and political stakes did not prevent the training of numerous trade union leaders, representatives of Youth and Sport authorities, and high-ranking civil servants for the French State.

The Third Reich eventually gobbled up the ring of lands lying around its borders. The first two borderlands of annexation joined the Third Reich during what have since been called peaceful annexations, although the overwhelming German military pressure exerted should leave us in no doubt about how 'peaceful' they were. Together with the Sudetenland, the Hlučin territory was annexed in September 1938 as a result of the Munich Agreement. The annexation of the Memel region followed in March 1939, a few days after German troops had marched into Prague and had installed the Protectorate of Bohemia and Moravia. The Molotov-Ribbentrop Pact from August 1939 lay at the basis of the German intervention in Poland on 1 September, starting the Second World War. As a result, the Western borderlands of Poland were annexed to the Third Reich and German authorities installed a General Government on the rest of what had been Polish territory. Germany's expansion to the West followed in May and June of the year 1940, when the Netherlands, Belgium, Luxembourg and a big part of France were invaded, and the borderlands Eupen-Malmedy and Alsace-Lorraine were annexed. Unlike the other regions Germany lost after World War I, North Schleswig was never re-annexed by the Third Reich during the Second World War, although it was occupied between 1940 and 1945. It has been argued Nazi ideology prevented annexation, because Danish citizens were considered equally Aryan and the local inhabitants of North Schleswig were supposed to facilitate contact making between Danes and Germans ${ }^{68}$ It lasted until the autumn of 1944 when Allied forces reached the Alsace and the northern part of the EupenMalmedy region. The southern part of the latter region, including the city of Sankt-Vith, became the battlefield for Hitler's Last Offensive in the Winter of 1944-45. In the East, the Red Army reached the Memel region in the beginning

68 Steffen Werther, 'An Unimaginable Community: The SS Idea of a 'Greater Germanic Reich' and the German Minority in Denmark', in Norbert Götz, 'The Sea of Identities: A Century of Baltic and East European Experiences with Nationality, Class, and Gender' (Huddinge: Södertörn University, 2014), 85-108. 
of 1945, and marched on to the pre-war Polish borderlands of annexation within a couple of weeks. The Hlučin region, however, remained annexed until the end of the Second World War in May 1945.

We possess little comparative insights on the way the Second World War affected the European borderlands of annexation. The first systematic comparison of the persecution of Jews concluded that Nazi anti-Semitic policies were not simply implemented from above, but were adjusted to the local contexts of the borderlands, the international situation, and the changing interests of Nazi authorities themselves.$^{69}$ With reference to the war situation of children in borderlands, most attention has been paid to the Slavic and Jewish children who were most likely to be killed, Germanised or forced into child labour. ${ }^{70}$ Other researchers, however, showed that the division lines Nazi war policies drew between racial groups (often privileging children from the West above those coming from the East) were often obscure and reached the widest form of elasticity in borderlands. Both in the Alsace and in East Upper Silesia, Ryszard Kaczmarek argued, nationalist policies aimed to include many borderland inhabitants into the German Volksgemeinschaft. The means to achieve this goal, however, were different. Whereas in the Alsace, borderland inhabitants could easily receive German citizenship, in the annexed territories of former Poland, such citizenship was only granted after a clear examination of the individual's past and present activities. Interestingly, in both regions, youngsters often received German citizenship earlier than their parents, because it facilitated their enrolment in the German army. ${ }^{71}$ Hagen Stöckmann displayed a transnational history on German educational experiments in borderlands of annexation where pupils of what were considered inferior races were given a genuine German education in order to find out whether it could turn

69 Jörg Osterloh, Wolf Gruner, 'Einleitung, in Jörg Osterloh, Wolf Gruner, eds., 'Das “Großdeutsche Reich" und die Juden. Nationalsozialistische Verfolgung in den "angegliederten" Gebieten' (Frankfurt am Main: Campus Verlag, 2010), 10.

70 Ines Hopfer, 'Geraubte Identität: die gewaltsame "Eindeutschung" von polnischen Kindern in der NS-Zeit' (Wien: Böhlau, 2010); Dieter Steinert, 'Deportation und Zwangsarbeit. Polnische und sowjetische Kinder im nationalsozialitischen Deutschland und im besetzten Osteuropa 1939-1945' (Essen: Klartext Verlag, 2013).

71 Ryszard Kaczmarek, 'Zwischen Regionalismus, Autonomismus und Separatismus. Das Elsass und Oberschlesien, 1871 bis 1945', in Christian Pletzing, Peter Oliver Loew, Thomas Serrier, eds., 'Wiedergewonnene Geschichte. Zur Aneignung von Vergangenheit in den Zwischenräumen Mitteleuropas' (Wiesbaden: Harrassowitz, 2006), 183. 
them into valuable members of the Volksgemeinschaft. ${ }^{72}$ Ruth Leiserowitz, lastly, pointed to both the changeability of nationalist policies towards Wolfskinder, German orphans who during and shortly after the war wandered around in Lithuania, the Memel region, and Kaliningrad, before migrating abroad, and the way these children gave meaning to their experiences later in life. ${ }^{73}$

Once the Second World War was over, nation-states throughout Europe considered the annexations of their interwar territories to have been illegal and re-annexed their borderlands. The territories that shifted back and forward in the 1930s and 1940s remained more or less the same, except from in Poland. Whereas interwar Poland had included most of the Prussian province of Posen, most of the province of West Prussia, the east part of Upper Silesia and a small area of East Prussia, as a result of the international conference in Potsdam in 1945, its successor also incorporated East Prussia, the rest of Silesia, Pomerania, East Brandenburg and the city of Gdańsk. Contrary to the situation after World War I, the prevailing conviction during international peace negotiations taking place after the Second World War, was that an ethnically clean nation-state was deemed desirable, with minorities being considered 'a cause of conflict per se. ${ }^{74}$ As a result, the massive number of about 16 million people in Eastern Europe were asked to leave or were deported between 1944 and 1949 (compared to 2.8 million people between 1912 and 1925). ${ }^{75}$ About 7.5 million Germans, for example, left, fled or were expelled from the territories that were annexed to Poland in 1945. About 6.5 million Polish citizens settled in these territories between 1944 and $1949 .{ }^{76} \mathrm{In}$

72 Hagen Stöckmann, 'Being educated or being selected? Processes and dynamics of childrens' education in schools for 'ethnic Germans' and 'national political institutes of education' between centre and periphery', Conference Paper, 'Growing Up in 20th Century European Borderlands'. (Vienna: University of Vienna, 2015).

73 Ruth Leiserowitz, 'Von Ostpreussen nach Kyritz: Wolfskinder auf dem Weg nach Brandenburg' (Potsdam: Brandenburgische Landeszentrale für Politische Bildung, 2003).

74 Hans Lemberg, 'Grenzen und Minderheiten im östlichen Mitteleuropa - Genese und Wechselwirkungen', in Hans Lemberg eds., 'Grenzen in Ostmitteleuropa im 19. und 20. Jahrhundert. Aktuelle Forschungsprobleme' (Marburg: Herder-Institut, 2000), 179.

75 Philipp Ther, 'The Dark Side of Nation-States: Ethnic Cleansing in Modern Europe' (New York: Berghahn Books, 2014), 416.

76 Witold Sienkiewicz, Grzegorz Hryciuk, 'Wysiedlenia wypędzenia i ucieczki 1939-1959' (Warszawa 2008). 
the Hlučin region, in addition, 2,500 local inhabitants lost the rights to the land they had previously bought. ${ }^{77}$

Danish, Belgian and French authorities decided to handle postwar questions of war criminality within their systems of legal principles, rather than opting for deportation, but it could be asked whether the consequences were often not similar for the people experiencing them. In the case of Eupen-Malmedy for example, Belgian courts annulled the Belgian citizenship of 1,325 male citizens, along with their families, who saw no reason to stay and left, mostly for occupied Germany. ${ }^{78}$ One should also not forget that its inhabitants were better informed about the imminent arrival of the U.S. army, than many inhabitants in Central and Eastern Europe were regarding the arrival of the Red Army. As locals in Eupen-Malmedy who had been cooperating with the Nazi regime had had more time to leave, less were left to be condemned in the early postwar period.

The obsession with ethnically pure nation-states diminished the ambitions of supervision over the treatment of non-dominant groups on an international level. The successor of the League of Nations, the United Nations, focused on individual freedoms instead of on rights for what had in the interwar years been called minorities. ${ }^{79}$ This change put an end to the special conditions minorities in Eastern Europe had enjoyed, and foresaw a one-dimensional integration of the borderlands of annexation within their nation-states. The Memel region, East Upper Silesia and the Free City of Danzig all lost the autonomous status they had held during the interwar years. The international approach towards minorities was enhanced by the geopolitical set-up that would dominate European politics over the next 40 years. As conflicts over minorities between nation-states operating either before or behind the Iron Curtain threatened to erode the internal political stability of the bloc during the Cold War, they were brought to a halt. The reaction to the protests in the Polish border city Poznań in 1956, for example, made it very clear for Warsaw Pact countries that the acceptance of Soviet hegemony was something they needed to live with.

We possess less insights into the past life-worlds of children in European borderlands of annexation for the period after the Second World War than for the interwar period, because relevant archived policy documents are often not yet accessible for historical research and the people who experienced the 1940s

77 René Petráš, 'Zánik meziválečného systému práv menšin v poválečné ČSR', in Václav Houžvička, 'Odsun Němcůz Československa 65 let poté' (Brno: CDK, 2012), 97-109.

78 Carlo Lejeune, 'Die Säuberung, Bd. 2: Hysterie, Wiedereingliederung, Assimilierung (1945-1952)’ (Büllingen: Lexis-Verlag, 2007), 83-85.

79 Mazower, 'Minorities' 59. 
and 1950s as children are only now coming into the crosshairs of oral historians. Machteld Venken discovered similar nationalising mechanisms at work in the purification of the teaching profession in Eupen-Malmedy and Upper Silesia in the early years after the Second World War. ${ }^{80}$ As it turns out, the making of politically reliable borderland inhabitants was not 'a unique communist phenomenon. ${ }^{31}$ In many borderlands of annexation, researchers have recently started to record the stories of ordinary borderland inhabitants. ${ }^{82}$ Based on interviews with family members of different ages, the sociologist Helena Kubátová, for example, recently researched changes in the way of life of borderland inhabitants in the Hlučin region over the last 60 years. She discovered modernisation processes influenced the lives of borderland children later than elsewhere in Czechoslovakia because the local population devoted more time to their families and the practice of their religion..$^{83}$ The three contributions this edited volume offers about the post-Second World War period drew on archival material not previously subjected to historical interpretation, and whether or not in combination with newly created oral interviews, shed light on various aspects of children's past life-worlds.

Beata Halicka investigated the situation of children in the Western borderlands the Polish state gained after the Second World War. As a result of forced migration and, in many instances, the almost complete exchange of populations, this region experienced a significant social transformation. Halicka used the personal memoirs settlers sent in for a writing competition organised in the late 1950s in order to unravel childhood memories on family life and school experiences, as well as the mechanisms lying behind the construction of these memories. Despite the fact that the collection only enables us to get to know the viewpoints of settler borderland inhabitants, and not, for example, about the children whose families

80 Machteld Venken, 'Nationalization Campaigns and Teachers' Life Paths in BelgianGerman and Polish-German Border Regions (1939-1956)', Nationalities Papers: The Journal of Nationalism and Ethnicity 42, 2 (2014), 223-241.

81 Blaive, Oates-Indruchová, 196.

82 Reiner Mathieu, 'Knechte: Einblicke in den Alltag ostbelgischer Jungmänner im 20. Jahrhundert' (Eupen: Grenz-Echo Verlag, 2010); Reiner Mathieu, 'In Stellung: Einblicke in das Leben ostbelgischer Dienstmädchen im 20. Jahrhundert' (Eupen: Grenz-Echo Verlag, 2008); Reiner Mathieu, 'Wir durften studieren' (Eupen: GrenzEcho Verlag, 2014); Klaus-Dieter Klauser, Carlo Lejeune, 'Die Säuberung. Band 3: Verdrängte Erinnerungen - 340 Zeitzeugen berichten’ (Büllingen: Lexis Verlag, 2008).

83 Helena Kubátová a kol., 'Mezigeneračníproměny způsobu života na Hlučínsku’ (Praha: SLON, 2015), 332. 
had inhabited these borderlands for a longer time, it offered a unique insight into the way children experienced harsh living conditions, dealt with wartime memories and longed for a lost homeland.

Tobias Haimin Wung-Sung analysed how what he called North Schleswig German identities were negotiated and manifested in children's education, from the end of the Second World War until 1970. The most revealing insight is that North Schleswig's Sonderweg during World War II, as it was the only territory of the European borderlands of annexation which was occupied instead of annexed, did not yield to a significantly different Danish policy once the Second World War was over. Just like in the border regions that had been annexed, the new regime sought ways to compensate for the war damage. In North Schleswig, German private school buildings were confiscated and education in German was banned. Wung-Sung showed how local inhabitants redefined their identifications primarily by means of their visions on primary school teaching. Because speaking German was regarded as vital for the collective's survival, major efforts were invested in enabling and proliferating private teaching in German again from the 1950s onwards. Gradually, binary views on national identities were replaced by an inclusive stance combining regionalism with legal loyalty to Denmark and a cultural connection with Germany.

The contribution of Andreas Fickers brings us to the end of the 1960s and the beginning of the 1970s, when the cultural emancipation of Belgium's German speaking border inhabitants was negotiated. His piece goes against the current dominant belief in the region that autonomy was achieved through political negotiations, and argues that the reason for the radicalisation of the autonomy debate can be found in the generational conflict between those who experienced the Second World War as children and those born during or shortly afterwards. The latter grew up in an atmosphere of political lethargy and only became aware of their political potential when they were called to take up positions in the debate between Flemish and Walloon students about the linguistic profile of the Catholic University of Leuven. That experience lay at the basis of the negotiations about the region's autonomy this younger generation had with older political representatives. In the end, Fickers argued, the postwar children turn out to have been more of a transition generation characterised by genealogical tensions than the founding generation of autonomy they today profess themselves to have been. 


\section{Borderland Studies Meets Child Studies}

Taken together, the contributions first and foremost show the complexity of nationalisation within various, previously often undiscovered, spheres of borderland children's lives. In the various empirical contributions to this volume, one can detect nationalist practices in their purest form. Christine Maurer and Gabrielle Ripplinger pointed to the crucial importance German nationalists bestowed upon social child policy in the Alsace region. At the beginning of the $20^{\text {th }}$ Century, German architects designed a pompous modernist building for Strasbourgeain orphans that could hardly remain unnoticed by their French neighbours across the border as a demonstrative landmark of progressive hygienist beliefs. Unfortunate Alsatian orphans came to live in the most progressive buildings in their region, one of the first buildings with well-equipped bathrooms, running water and showers. Germany brought the best it had on offer to the borderlands and used social child policy as a weapon in the symbolic battle of modernity. Halicka revealed how unaccompanied German-speaking children lost out as a result of flight, expulsion and deportation, finding themselves in the borderlands that had just become Polish territory, experienced a lack of human compassion due to scarce resources being distributed along national lines. While Polish children had a greater chance to receive material support and medical aid, German children were charged with the sins of their parents. The way societal difference was practiced in the early period after the Second World War reached an extreme in the treatment of children ${ }^{84}$, and the mixed population in Polish Western borderlands makes it easier for historians to observe the outcomes of such practices. At the same time, as Maurer and Ripplinger observed, while researching the practices of caregivers operating within the Strasbourg orphanage, they found very little on nationalist ideology. As discussed above, non-national practices also held sway in the way children from borderlands of annexation approached primary schooling.

The contributions in this edited volume deepened our insights into the policies nationalists developed for borderland children after both World Wars. After the First World War, conceptions of civil versus ethnic nationalism were decisive for organising collective rights as minorities in the East of the European continent, but not in the West. Interwar nationalist educational policies in European

84 Machteld Venken, Maren Röger, 'Growing Up in the Shadow of the Second World war. European Perspectives. Introduction', in: Maren Röger, Machteld Venken. Growing Up in the Shadow of the Second World War. European Perspectives. Special Issue of: European Review of History - Revue européenne d'histoire 22 (2/2015), 199-220. 
borderlands of annexation, however, did not reflect the dichotomous spatial way of thinking about nationalism that had prevailed at French negotiation tables in 1919. Evaluating the way nationalists allowed German-speaking inhabitants to develop their own activities in, inter alia, European borderlands of annexation, Ingo Eser placed Polish nationalists in between 'softer' Danish and 'harsher' French nationalists. ${ }^{85}$ The first evidence about the youth organisations operating in European borderlands of annexation provided in this edited volume serves to support that insight. Julien Fuchs found Alsatian youth movements on the whole to be Francophile and characterized pro-German movements as marginal, politicised and separatist. Ruth Leiserowitz revealed that authorities required youth organisations in the Memel region to hold profiles different to those in the rest of Lithuania after the coup détat of 1926. Despite being very similar to their Lithuanian counterparts, sport clubs in the Memel region were not allowed to speak out on political matters. Although the Lithuanian Ministry of Education also forbade some political youth organisations to operate in Lithuanian's heartland in 1930, other than in the Memel region, this measure was only initiated on the basis of concrete experiences of political provocation. In contrast, in the Eupen-Malmedy region, North Schleswig and the Polish interwar borderlands of annexation, youth organisations of German minorities appeared to have had more freedom to develop a regional (whether politicised or not) profile. ${ }^{86}$ Taken together, these insights revealed that the openness of youth organisations towards people with different national, ethnic or religious affiliations was not primarily defined by their territorial location in either the East or the West of Europe.

The authors in this edited volume also provided evidence that widens our knowledge about the characteristics of nationalist education in borderlands after the Second World War, when the recipe to guarantee peace on the European continent was believed to lie in a combination of putting borders in place and creating a more homogeneous population within the borders of nation-states. This edited volume offered insights into the consequences that recipe entailed

85 Eser, 666.

86 Katja Schenk, 'Les mouvements de jeunesse germanophiles dans le canton d'Eupen pendant l'Entre deux-guerres', Thesis, Université de Liège, 1997; Peter Nasarski, 'Deutsche Jugendbewegung und Jugendarbeit in Polen: 1919-1939' (Würzburg: Holzner, 1957); Eric Wiesemes, 'Die Organisation "Hitlerjugend” im Gebiet von Malmedy-St. Vith 1940-1944' (St. Vith: Zwischen Venn und Scheifel, 2000); Nina Jacobsen, 'Tysk nazistisk ungdomsarbejde i Nordslesvig 1933-1945', Sønderjyske Årbøger (1996), 195-222. 
for children attending schools in borderlands of annexation. Beata Halicka delivered the clearest example of the importance borderland inhabitants attached to their schools. In the devastated lands that had just joined Poland, setting up schools was a spontaneous social activity lying at the very basis of the process of rebuilding community life. Only when state representatives took over control were schools turned into tools for nationalisation. As Andreas Fickers and Tobias Haimin Wung-Sung showed in this edited volume, school representatives in Eupen-Malmedy and North Schleswig had similar aims. At the same time, however, the effect of such attempts were limited because nationalist policies were either not addressed towards the specific needs of borderland children, or children appeared more influenced by the lifestyle of their parents who were still coming to turns with the legacy of the war. Wung-Sung therefore advocated opening up the nation-central approach research on education tends to take. Without looking at the family context of the borderland pupils in North Schleswig, he argued, one cannot understand the reasons for the failure of the Danish school system's attempt to enhance pupils' integration into society after the Second World War. Even within the Danish language association, it became clear that the challenge did not primarily lie in making children from German-minded homes enjoy Danish schools, but in building trust with many of the children's parents.

These insights display continuities with what Andreas Kazamias and others revealed about the educational policies developed for non-dominant groups in Europe in the interwar years. As was the case before the Second World War, such policies were equally nationalistic in Western and Eastern Europe, and non-dominant groups all over the European continent appeared reluctant to accept them, if they did at all. Two important observations, however, mark significant differences between the two time periods. The requirements of nationalists with regards to children's language teaching were harsher after the Second World War, than they had been in the interwar years. In the late 1940s, German was banned from or reduced to a minimum in school curricula in all European borderlands of annexation. ${ }^{87}$ The idea prevailing by that time that non-dominant groups, instead of nation-states themselves, were endangering the stabilisation of peace and order in Europe, found a very clear articulation in school politics. In addition, borderland children made use of the chances offered by the democratisation of secondary education after the Second World

87 Piotr Madajczyk, 'Niemcy polscy 1944-1989' (Warszawa: Oficyna Naukowa, 2001), 32; Ursel Schmitz, 'Zur bildungspolitischen Entwicklung des Sprachenproblems in den belgischen Ostkantonen seit 1945’ (Frankfurt am Main: Peter Lang, 1993). 
War later than children in other regions of their countries. ${ }^{88}$ They often opted only to fulfil minimal educational requirements, which contributed to the fact their regions remained for much longer, as Andreas Fickers formulated it in this volume, 'educational deserts'.

Reading the contributions together, I came to develop a new hypothesis. With his analysis of the Danish coloured caps, which the first pupils of the reopened secondary schools for German speakers in North Schleswig wore on their graduation ceremony in the early 1960s, Tobias Haimin Wung-Sung showed how youngsters who were supposed to act as the German-speaking new elite no longer shared the isolationist national convictions of their parents. Adopting a Danish tradition did not threaten their identity, but was considered an asset in functioning in a border region where different cultural spheres meet. In his analysis of Alsatian youth movements, Julien Fuchs explained how Claude Marx, a member of an Alsatian youth organization, offered a useful solution for youth organisations in the entire French country to break through the crisis they were experiencing at the end of the 1950s, when members found their organisations too institutionalized and too much controlled by adults. Claude Marx came up with the idea to install youth councils that based their working on the views of young people and allowed for cooperation beyond the existing institutional setup. First tried out in the Alsace, the model of youth councils spread throughout the country in the following five years. That the solution was proposed by an Alsatian troop leader does not come as a surprise. While in exile in the centre of France during the Second World War, Alsatian youth movements had learned to put aside their differences in order to be able to cultivate Alsatian solidarity and to rescue Jews. Although successful, youth councils became less popular after the French Ministry of Youth Affairs and Sports established a centralised system promoting direct intervention in 1966.

Andreas Fickers analysed how student protests at Belgium's biggest university in 1968 provoked the politicisation of the students from the Belgian Eastern borderlands, who were later able to negotiate a form of cultural autonomy fitting within the framework of the dismantling Belgian nation-state. Beata Halicka cited the memoir of a little girl, Izabella Grdeń, who after having moved from the eastern borderlands Poland had just lost, settled in the Western territories Poland had just gained. Her parents kept on longing for their lost homeland and did not

88 Andrzej Sakson, 'Stosunki narodowosciowe na Warmii i Mazurach 1945-1997' (Poznan: Instytut Zachodni, 1998), 261; Helena Kubátová a kol.,'Mezigeneračníproměny způsobu života na Hlučínsku' (Praha: SLON, 2015), 331. 
develop the social skills that would have enabled them to live comfortably. Izabella, on the other hand, did not have such a strong attachment to the place where she was born, and as a result found it easier to find her place in society. When she and her brother later started to work, they could even provide not only themselves but also their parents with the financial means to improve their living conditions.

These are all examples of creative solutions borderland children worked out in active negotiation with nationalists from the heartland in order to solve the problems they experienced in their daily lives. These practices emerged after borderland children had engaged with nationalist ideas, and offered solutions that could be integrated within the policies of the nation-states the children inhabited. Whether or not their solutions were integrated in policies depended on the degree of openness nation-states displayed. Both in the Polish Western borderlands and in the Hlučin region, for example, such openness was noticed already in the early aftermath of the Second World War, where new communist regimes sought to encourage the social advance of children with a peasant or blue-collar working background. Beata Halicka made clear that that idea yielded its most concrete results among children who had come to settle in these borderlands, since, deprived of material belongings, they found it relatively easy to switch their attachment from goods to knowledge and skills. The youth councils developed in the Alsace provided the answer to the overinstitutionalised youth culture in France in the 1960s, until the Ministry made clear its ambition to play a central role in organising the leisure time of French youth in 1966. Only four years later, in contrast, did the Belgian nation-state witness the first state reforms in response to the Flemish demand for cultural autonomy. A Belgian nation-state slowly falling apart had more opportunities to handle the demands of its Eastern borderland youngsters for an increase of their autonomy in 1973 than the French nation-state had in 1966.

The fact that the creative solutions of borderland children to the problems they came to define for themselves in their environments appeared in both the Eastern and Western European borderlands of annexation ought to prompt us to rethink the obvious explanations we have been given. Perhaps communist callings for social advance did not prove decisive, but were in fact only an additional factor in bringing about such practices in the East, a factor that caused them to appear earlier than in the Western borderlands of annexation witnessing a continuation of liberal political ideology. And perhaps the cause for the appearance of such creative practices in Western borderlands of annexation cannot be reduced to the bilateral agreements nation-states signed with Western Germany, such as the Belgian-German bilateral cultural agreement from 1956, influenced by the idea of political supranationalism the European Coal and Steel Community (ECSC) 
had been emulating since the early 1950s, and the Copenhagen Declaration from 1958 enabling West Germany's entrance into NATO. ${ }^{89}$ What the initiators of these creative practices held in common was that their home grounds had shifted as a result of international decisions concerning the safeguarding of peace in Europe. The kind of Europeanisation peace negotiators had in mind after the Second World War, implying the one-way integration of non-dominant groups within their nation-states, also may as well have been spontaneously supported by borderland children through some of their practices.

The authors of the empirical studies offered in this edited volume all point to differences in opinion between parents and their children, and, notwithstanding the actual age of the historical actors, put a decisive factor for the emergence of their creative practices in demography. This may not come as a surprise, as the children found themselves at the centre of nationalist interests in political programs about the integration of their borderland of annexation into the nationstate. Since their practices offered specific responses to local circumstances, and could be noticed when nation-states provided the openness to pay attention to them, an attempt to put borderland children into more precise age categories may fail to discover these practices in the first place, and certainly does not enable us to compare them throughout 20th Century Europe.

Although coming up with solutional practices seemed more common after the Second World War than before, only more diachronic research can shed light on what, in Julien Fuchs's study, appears to be the tidal rhythm of their emergence and disappearance over time. Albeit youth councils did not receive French political support after 1966, in the years between the First and Second World Wars, Alsatian youth hostels were needed in order to give the French political ideal of pacifism a concrete location. Opposing the militarist Republican doctrine from before the First World War, this ideal was a political goal that intended to increase cohesion in interwar French society. As a matter of fact, the first French youth hostels arose in the 1930s in the Alsace region and were inspired by the German youth hostel movement, which enjoyed a much longer tradition. The Alsatian youth hostels provided the place where German and French youngsters could meet and express their antimilitarist convictions. In this way, the borderland enabled youngsters to contribute considerably to the dissemination of the French political ideal of pacifism.

89 Carlo Lejeune,'Die deutsch-belgischen Kulturbeziehungen 1925-1980' (Köln/Weimar/ Wien: Böhlau, 1992), 322; Karl Christian Lammers, 'Living Next Door to Germany: Denmark and the German Problem', Contemporary European History, 15, 4 (2006), 453-72. 
I have been granting much more attention to what I call the creative solutional practices of borderland children than the authors of single chapters in this edited volume, not because they were more numerous or more important than the nationalist and non-nationalist practices the authors often foregrounded, but in order to risk venturing beyond a dichotomous dialectic and to present borderland children as historical actors capable of producing various kinds of practices in a place where meaning remained contested.

What ultimately did the case-study on children's past in European borderlands of annexation tell us about Europeanisation? It revealed that where children from borderlands of annexation grew up, either in the East or in the West of the European continent, was not a decisive factor in the practices they developed. It also demonstrated prevailing continuities in the characteristics of their practices between the interwar period and the period after the Second World War. How then, finally, to answer the question concerning Europeanisation? What is the relationship between the polemicised Europeanising character of the peace conferences following both World Wars and the practices of children inhabiting European borderlands of annexation? Thanks to a comparative reading of the chapters in this book, I can hypothesise that children, through some of their practices, put themselves to the fore in contributing to a more stable, peaceful Europe. And yet, although borderland children offered creative and context specific solutions to the way international order had been established in Europe, they never referred to their practices as Europeanising. Peace negotiators held intense discussions about Europeanisation, and the various European borderlands of annexation called into being as a result of these discussions embodied the contradictions that had been lying at the heart of their debates. Borderland children, however, often saw the world through local glasses while solving such contradictions through verbal or non-verbal practices that helped to integrate their borderlands of annexation into their nation-states, and vice versa. Still, we can detect a 'similar process' in the way their practices 'impacted the shape of the European 20th Century', and here we are back at von Hirschhausen and Patel's definition of Europeanisation. Afraid to 'succumb to an essentialist, normative and selective view of Europeanisation', they proposed that historians use the term Europeanisation only if historical actors used it at the time..$^{90}$ But in the light of the findings presented in this edited volume, that proposition appears to be too rigidly based on a traditional assumption

90 Ulrike von Hirschhausen, Kiran Klaus Patel, 'Europeanization in History: An Introduction', in Martin Conway, Kiran Klaus Patel, eds., 'Europeanization in the Twentieth Century: Historical Approaches' (Basingstoke: Palgrave Macmillan, 2010), 2, 10. 
of what constitutes a historical agent, i.e. a rational person able to exert power over the word. The agency borderland children presented in this volume should encourage us to broaden that definition so as to include those whose actions, in a variety of local settings, contributed to making Europe more socially cohesive and thereby unwittingly furthered the cause of Europeanisation. Since the first evidence gathered in this edited volume is of a necessarily preliminary character, there is a need for further development and elaboration of this hypothesis in future research. 


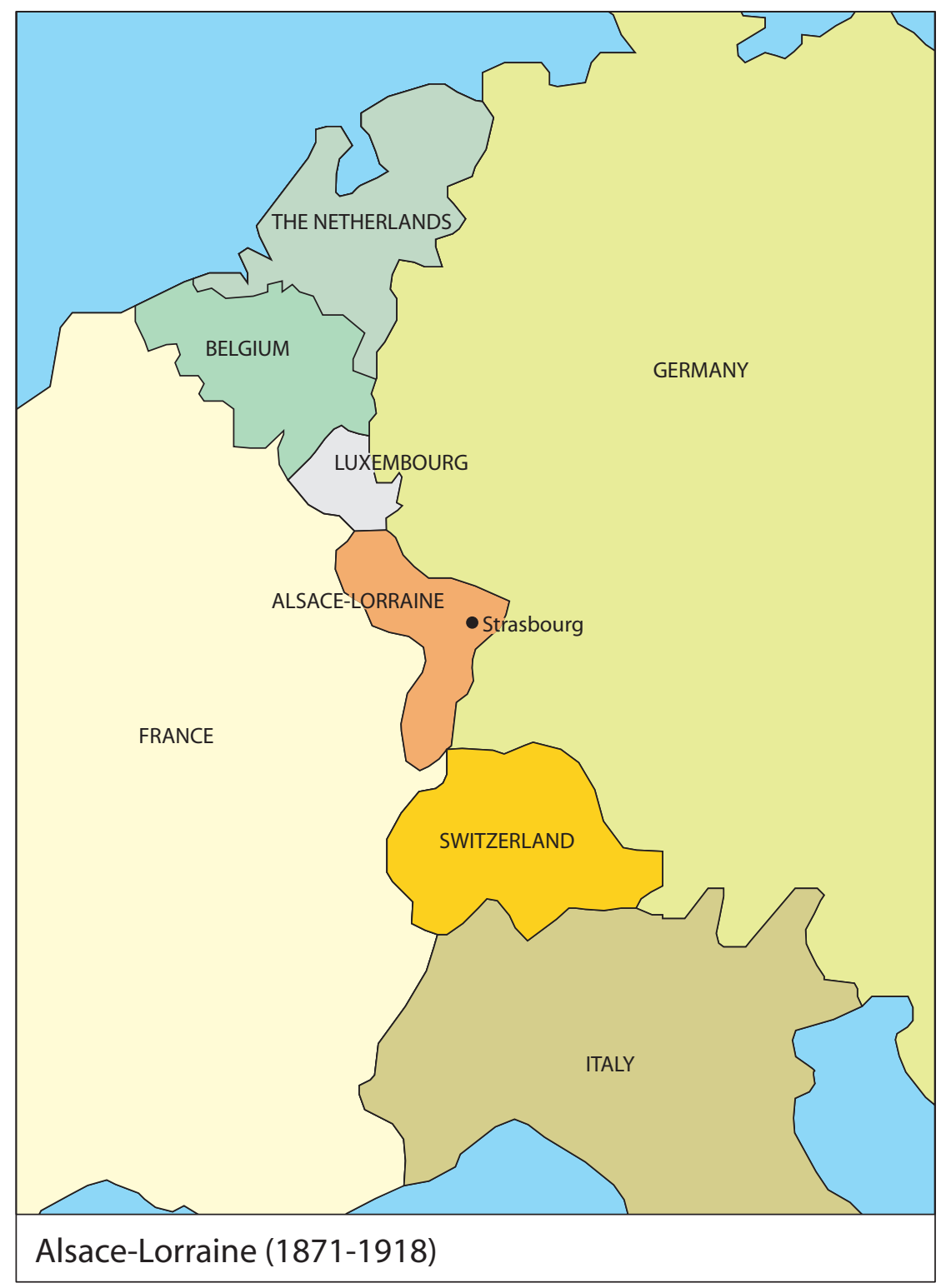

Map 2: Alsace-Lorraine 1871-1918. 


\title{
Catherine Maurer \& Gabrielle Ripplinger \\ Destitute Children in Alsace from the Beginning of the Twentieth Century to the End of the 1930s: Orphan Care in Strasbourg, in between France and Germany
}

\begin{abstract}
In the twentieth century, Alsace featured as the most perfect example of a European border region, regardless of the national area it was associated with, France or Germany. It had to suffer from all the ensuing geopolitical effects, changing hands three times within a quarter of a century: in 1919, it came back to France after forty years during which it had belonged to Germany; in 1940, it was annexed by the National-Socialist Reich, before being handed back to France in 1944-5. The region thus lies at the meeting point between two powerful states and two distinct linguistic, cultural and legislative areas. Its very strong linguistic and cultural links with the German space seem to be at odds with the much more inclusive approach to nationality defended by the French, a contradiction summed up in the famous controversy involving French historian Fustel de Coulanges (1830-1889) and German historian Theodor Mommsen (1817-1903). According to Fustel de Coulanges, 'nationality is created neither by race nor by language. Alsace [should] be thought of [...] according to its intimate involvement in the life of the French nation since the Revolution, which unquestionably has fostered a sense of being French', while Mommsen considered Alsatians as 'a German people who, out of natural necessity, should be united to the German homeland'. ${ }^{1}$ This tension between two radically distinct conceptions of the nation underlay the 1871 annexation of Alsace by the German Empire and remained strong up to the interwar period. Smith, however, argues that 'Alsatian identity cannot be confined to a definite, narrow sense of belonging. [...] The construction of their identity [provides] the example of an interweaving of attitudes ranging between demand, compromise, integration or rejection. This also leads to a challenge to the academic opposition between the French idea of the nation and the German conception of the people. ${ }^{2}$
\end{abstract}

Alsace can also be characterized by its religious pluralism. This fact, though it is not necessarily to be linked to its borderland location, remains essential and is relevant to our study. One specific element of Alsatian religious history is indeed connected to its borderland situation: the Concordat established in France in 1801 has been upheld in Alsace to this day, and has contributed to turning religion into

1 The quotations are taken from Paul Smith, 'À la recherche d'une identité nationale en Alsace (1870-1918)', Vingtième Siècle. Revue d'histoire, 50, 1 (1996), 23-35, 24.

2 Smith, 'À la recherche d'une identité nationale', 23. 
a public, and therefore legal, political and social matter, which is of interest for our study. When France established secular education (1881) and put an end to the Concordat through the separation between church and state (1905), Alsace belonged to Germany and was therefore immune to these legislative changes. The attempt to extend these laws to it after its return to France in 1919 was a failure, mostly owing to Catholic mobilization. That is why, due to their changing national situation, Alsatians' most precise and intimate identity has for a long time been founded on Alsace's religious status. ${ }^{3}$ A deeper look at the religious composition of the region shows that Catholics remain the dominant group in the twentieth century, accounting for a little more than $70 \%$ of the population. ${ }^{4}$ But Protestants, especially Lutherans, constitute a very influential group, the Jewish community is far from insignificant, and, in the second half of the twentieth century, the number of Muslims has steadily risen.

Within this general context, the specificities of Alsace are often underlined, even in academic papers, especially French. Yet the region is sometimes considered as a monad, as if floating on its own, cut off from the rest of the world. It is rarely studied as a borderland region, or compared to other borderland regions, hence the interest in choosing such an approach in this volume. Within this framework, our aim is to examine one specific group, destitute children, a group that is sometimes considered as marginal and yet allows several essential issues connected to the history of childhood to be considered: the attitude of adults and families towards children, the educational policies or the care programs set up by public authorities.

By 'destitute children', we mean children who lack the means of subsistence for economic reasons (they are often orphans) as well as for physical reasons (mentally handicapped children) or because they have moved to the margins of society, whether intentionally or not (delinquents, 'deviants' of all stripes). One obvious question could be to ask whether there is a specific way of caring for these children in Alsace, in a region where particular importance is granted to the family unit, wherein the child occupies a major part, due to the unstable nature of national identity. ${ }^{5}$ In other words, is there a specifically 'borderland' reality of destitute childhood, and a specifically 'borderland' way of approaching it?

First, a significant part of Alsace's population is made up of children. Up to the 1930s, the birthrate was higher than in other French départements, even if it was a little lower or equal to that or Germany: in 1930, the rate was 19.4 per thousand

3 Alfred Wahl and Jean-Claude Richez, La vie quotidienne en Alsace entre France et Allemagne 1850-1950 (Paris : Hachette, 1993), 11-2.

4 Wahl and Richez, Vie quotidienne, 122.

5 Wahl and Richez, Vie quotidienne, 13 and 95-169. 
for the Bas-Rhin, and 18 per thousand for France as a whole. ${ }^{6}$ The infant mortality rate was steadily decreasing, even if it remained for a long time higher among the Catholics than the Protestants, as Alfred Wahl has shown. ${ }^{7}$ All the destitute children living in Alsace were not necessarily born in Alsace and are thus not all included in these figures, but it is still useful to take into account this significant 'supply' of infant populations. Furthermore, like the other regions but sometimes more so, Alsace was hit by the twentieth-century economic crises and conflicts such as the Great Depression or the Second World War ${ }^{8}$, which provided their share of destitute children.

Several students from the University of Strasbourg have recently focused on the subject and tackled it from three different perspectives, studying the way the region cared for mentally handicaped children, ${ }^{9}$ for 'vulnerable', delinquent or destitute young girls, ${ }^{10}$ and for orphans. ${ }^{11}$ In each of these cases, the young researchers had to deal with various questions linked to Alsace's borderland status. The language used in the records, French or German, raised one immediate issue. At the beginning of the twentieth century, the German language prevailed, its dialect version still very much spoken up to the 1960s but hardly ever adopted in writing. German was thus used in written documents, up to the mid-twentieth century, even if there could be a mix of French and German during the French periods. The second issue has to do with the legislation that was applied in the periods under study: French, German, or sometimes even a combination of the two, at a time when there was a flurry of legislative measures regarding matters connected to childhood. Finally, the care policies and the educational methods differed, ranging from 'German' methods or 'French' methods to a combination

6 Wahl and Richez, Vie quotidienne, 96.

7 For a summary, see Wahl and Richez, Vie quotidienne, 95-101.

8 For more details, especially on economic crises, see Bernard Vogler and Michel Hau, Histoire économique de l'Alsace: croissance, crises, innovations (Strasbourg : la Nuée bleue, 1997).

9 Valentine Hoffbeck, L'enfance arriérée au début du XXe siècle : entre assistance et exclusion. L'exemple de l'Institut St-André de Cernay (1891-1939), Master's degree thesis, under the supervision of Catherine Maurer, University of Strasbourg, 2008.

10 Elsa Rossler, Protéger l'enfant ou le punir ? CEuvre de charité, œuvre de défense sociale : la maison déducation pour jeunes filles catholiques du Neuhof (1853-1918), Master's degree thesis, under the supervision of Catherine Maurer, University of Strasbourg, 2008.

11 Gabrielle Ripplinger, Lorphelinat municipal du Neudorf (1907-1940). La question de la prise en charge municipale de l'enfance orpheline à Strasbourg dans la première moitié du XXe siècle, Master's degree thesis, under the supervision of Catherine Maurer, University of Strasbourg, 2015. 
of the two. These three questions will be tackled here through the case study of the situation of orphans in Strasbourg from the end of the nineteenth century to the end of the 1930s. ${ }^{12}$ The 1940 evacuation of the residents of the municipal orphanage of Strasbourg to Dordogne, their return only occurring after the end of the German occupation in a radically different political, economic and social context, represented a clear break with the preceding period and makes for an appropriate stopping point to our study.

'In the nineteenth century, Alsace, which was located at the crossroads between Swiss, French and German influences, was a real breeding ground for new ideas concerning education .....13 ${ }^{13}$ ore particularly concerning the education of destitute children. In that respect, focusing on the municipal orphanage of Strasbourg inevitably leads the researcher to a number of major questions. What role did Alsace's geopolitical situation play in establishing a legislative framework for dealing with destitute, orphaned children in the region and what was its concrete effects on the orphanage's day-to-day management? What was the respective part of French and German influences in the design - particularly, the architecture - of the place and in its day-to-day functioning? Finally, did the residents and staff take a particular approach to the issue of nationality, given their borderland situation?

\section{The general administrative and legislative context}

In the twentieth century, the municipal orphanage of Strasbourg was part of a wide range of welfare policies. Indeed, Strasbourg had developed early on an intense concern for its most destitute populations. Strasbourg had become a free city in the Middle Ages and enjoyed a rather large autonomy. It defined its own jurisdiction, police rules and managed its own charitable institutions. Consequently, 'a solid institutional framework as far as charitable matters are concerned is one of the hallmarks - it has remained so under France's control - of a threefold system, ${ }^{14}$ comprising the Hôpital des Bourgeois, the chaplaincy Saint Marc and the Maison des Orphelins (the 'House of the Orphans'), the ancestor of the institution here under study. A special type of

12 This study is heavily based on Gabrielle Ripplinger's Master's degree thesis.

13 Jean-Rémy Butterlin, 'L'éducation correctionnelle dans le Bas-Rhin au XIXème et au début du XXème siècle : un foisonnement d'institutions', in Conservatoire national des archives de l'histoire de l'éducation spécialisée, ed., Contribution à l'histoire des grands courants confessionnels et laïques en Alsace dans le travail éducatif et social du Moyen Âge au XXe siècle (Strasbourg: Cat l'essor, 2003), 23-38, 23.

14 Elisabeth Sablayrolles, L'enfance abandonnée à Strasbourg au XVIIIe siècle et la fondation de la Maison des enfants-trouvés (Strasbourg: Istra, 1976), 4. 
assistance reserved for orphans had been organized rather early on: the Hospice des Orphelins (the 'Orphans' Hospital') had probably existed since the early fourteenth century, having probably been founded shortly after the great plague of $1315-6 .{ }^{15}$ When Strasbourg came under French control, in 1681:

to each age class, to each type of hidden or displayed indigence, almost to each disease corresponded specific charitable institutions which mostly dated from three centuries before and which owed their particular shape to the Reformation which had allowed them to gain possession of the secularized goods of monasteries and had accelerated the transition to a secular form of administration. ${ }^{16}$

After coming under French control, the city carried on the same tradition: with the rise of natalism, abandoned children and orphans were conceived of as future French citizens that had to be protected, mainly from disease and perversion. It was almost certainly at that time that there occurred a shift in the definition of assistance from a type of assistance based on charity to one based on specialized social institutions. On 14 September 1748 a charitable institution specifically intended to educate, welcome and instruct abandoned children was created in Strasbourg, as a way to respond to the increase of 'expositions', i.e. abandoned children, and to reform the ways of dealing with them.

French legislation regarding the protection of childhood slowly became more specific. The revolutionary law of 28 June 1793 stated that 'the nation henceforward shall take care of the physical and moral education of the children known as abandoned children, who will henceforth indistinctly be called orphans. ${ }^{17}$ But a genuine state-defined system of public assistance was only set up under the Third Republic. At that time, Strasbourg belonged to Germany and was no longer concerned by French legislation. Certain children, indeed, would be cared for by the city itself all along the twentieth century, rather than by the département or the State: these 'municipal orphans' were not transfered to host families or private or public non-municipal institutions, as was the case for the children under the care of the Assistance Publique, ${ }^{18}$ but to the orphanage of the city. The distinction between 'municipal orphans' and the others (the figures vary but the municipal orphanage welcomed a hundred children each year between 1930 and

15 Ripplinger, Lorphelinat municipal du Neudorf, 23.

16 Sablayrolles, L'enfance abandonnée à Strasbourg, 6 .

17 Law adopted on 28 juin 1793 by the Convention, defining the bases of childhood protection by the State: see the list of legal texts in www.oned.gouv.fr/.../liste-texteslegaux-dans-leur-version-dorigine- (last visited on 18 July 2015).

18 On the Assistance Publique, see Ivan Jablonka, Ni père, ni mère. Histoire des enfants de l'assistance publique (1874-1939) (Paris: Seuil, 2006). 
1935) ${ }^{19}$ was based on geographical data (the parents had to be from Strasbourg or to have resided there for a long time) but also on less concrete data, based on notions of honor and dignity. The orphanage indeed only accepted children whose parents were considered as decent and respectable, as is shown in an extract of the Administrative Record of the City of Strasbourg for the years 1935-1939. The extract indicates that

the Office ${ }^{20}$ will take care of the orphans that cannot be cared for by their family after the death of their parents, and will take all due measures to have them admitted either as municipal orphans if they meet the required conditions of residence and dignity, or as children placed under the supervision of the département-based service of the Assistance Publique. ${ }^{21}$

German legislative and administrative practises certainly played a role in the preservation of this system as, generally speaking, they reintroduced in Alsace 'an ancient tradition of self-government by the cities dating from before $1789^{22}$ and favoured a local approach over appeal to the département or the nation, even after Alsace came back to France in 1919.

These specific public welfare policies were allied in Strasbourg to particularly dynamic private charitable organizations, in particular those specializing in child care. Their dynamism was also related to the very specific religious situation of Strasbourg and Alsace, partly derived, as we have seen, from its borderland location. The Catholic congregation of the Sisters of Charity of Strasbourg, who worked at the municipal orphanage, also managed other institutions designed to 'shelter abandoned children, exclusively or for a good part, ${ }^{23}$ in particular SainteBarbe, a small institution for girls located in Schiltigheim, and the orphanage Saint-Charles, well appreciated by the Superior General of the Congregation, who declared: 'I have only one wish concerning Saint-Charles, that ... the moral and Christian education of children should always be its first and foremost aim.24 Protestant institutions were also founded, such as the orphanage of Neuhof,

19 Ripplinger, L'orphelinat municipal du Neudorf (1907-1940), 63.

20 The Office municipal d'assistance et de prévoyance sociale (OMAPS): see further.

21 Administrative record of the City of Strasbourg, 1935-1945, vol.II (Strasbourg: Istra, 1948), 109-10. The passage in bold type has been underlined by Gabrielle Ripplinger.

22 Bernard Vogler, Histoire politique de l'Alsace: de la Révolution à nos jours (Strasbourg: Istra, 1995), 207.

23 Marie-Alfred (mère) Renaut, La congrégation des Sœurs de la Charité de Strasbourg. Petit aperçu historique (Strasbourg: Maison Mère de la Toussaint, 1945), 155.

24 Renaut, La congrégation des Sœurs de la Charité, 158. 
created in $1825,{ }^{25}$ shortly after the creation in 1822 of the orphanage of Beuggen, in Baden, or that of Düsselthal, in Rhineland.

Concerning the interwar period, the short booklets written by Auguste Hermann provide a good survey of the services and institutions the city of Strasbourg had set up to care for children in difficult situations. ${ }^{26}$ They present first the institutions supervised by the city through the Office municipal d'assistance et de prévoyance sociale (OMAPS). The OMAPS oversaw all 'social actions initiated by the municipal Administration. ${ }^{27}$ It acted as an intermediate body and managed directly a few municipal institutions, such as the Hospice des orphelins or the Children's municipal Asylum. ${ }^{28}$ It was also in charge of child and youth protection: 'in matters relating to guardianship, the Office carries out the functions of the Conseil communal des orphelins, according to local prescriptions' and remains 'the organ responsible for implementing the decisions of dependency courts, especially in matters relating to education and the management of the wards' fortune. ${ }^{29}$ As such, the Office worked alongside the services of the Assistance Publique, which were introduced as soon as Strasbourg came back to France and functioned at the level of the département. At the beginning of the 1920s, they tried to take control over the municipal orphanage, but their efforts remained fruitless despite the fragile financial state of the orphanage. ${ }^{30}$ The mayor of Strasbourg, Jacques Peirotes, thus declared in 1921 that supervision by the département

...would raise in Strasbourg a legitimate outcry. The orphanage is, indeed, considered by a great part of the population and especially by its ancient wards as an inherent part of the City itself, and it is clear that the reasons that are put forward today are not enough to justify that the City should give up an institution that has so admirably functioned for so many years. ${ }^{31}$

25 Georges Foessel, Le Neuhof, établissement protestant pour enfants, 150ème anniversaire (Strasbourg: 1975), 17.

26 Auguste Herrmann, Strasbourg social (Strasbourg: Istra, 1935), and Herrmann, Les sociétés strasbourgeoises de service social (Strasbourg: Istra, 1938).

27 Herrmann, Strasbourg social, 22.

28 Herrmann, Les sociétés strasbourgeoises, 31-2. The Asile municipal d'enfants was an annex to the Hospice des Orphelins and was designed to shelter abandoned children.

29 Herrmann, Les sociétés strasbourgeoises, 13.

30 Ripplinger, L'orphelinat municipal du Neudorf (1907-1940), 51-3.

31 From the speech preserved in the archives of the city of Strasbourg and quoted by Ripplinger, L'orphelinat municipal du Neudorf (1907-1940), 52. 
This twofold system, whereby orphans were cared for by the city and by the département at the same time, lasted in Strasbourg throughout the interwar years and even after.

Auguste Herrmann also describes the 'private Catholic charitable works of the Diocese of Strasbourg, ${ }^{32}$ mainly composed of denominational orphanages such as Saint-Charles, Sainte-Richarde in Andlau, the orphanages of Guebwiller, Thann, Mulhouse-Dornach, Willerhof and Neuf-Brisach (for boys) or those of Saverne, Hilsenheim, Ebermünster, Niederbronn, Mulhouse, Saint-Joseph (Strasbourg) and Steinkreuz (Colmar) (for girls). Finally, he mentions the Protestant and Israelite institutions, such as the Patronage committee for the assisted children of Strasbourg and the country or the Israelite girls' orphanage of Strasbourg. ${ }^{33}$

The municipal orphanage was thus part of the fabric of 'an ancient city [which] has always led the way of social action [and which] has remained imbued with the idea that there are some principles of social justice that must be shared. ${ }^{34}$ This 'ancient city', however, was also shaped by the influence of several religious denominations and by French and German interventions in its administrative and legislative framework. This climate of emulation, rather unique in Europe, is likely to have had positive effects on the diversity of actions undertaken to deal with orphans, thus turning the borderland city into a testing ground for social action. Can the same be said regarding the design of the place, more particularly its architectural design?

\section{Architectural design and borderland situation}

In 1904, a fire destroyed the orphanage, then located in the ancient monastery Sainte-Madeleine, in the centre of the city. Total reconstruction proved necessary, but the huge reconstruction works also provided an opportunity to create a radically new building. The new orphanage was to be built in 'a neighborhood of Neudorf filled with light and fresh air, far from the cramped atmosphere of the centre. ${ }^{35}$ The new design had been selected after an architectural competition had been organized in the whole Reich and won by Ernst Vetterlein. ${ }^{36}$ The building, whose

32 Herrmann, Les sociétés strasbourgeoises, 103-12.

33 Herrmann, Les sociétés strasbourgeoises, 133-5, 144 and 156-7.

34 Herrmann, Strasbourg social, foreword.

35 Association des anciens élèves du foyer de la jeunesse Charles Frey, $130^{\text {ème }}$ anniversaire ! (Strasbourg: Editions du Meiselocker, 2007), 13.

36 Ernst Vetterlein was born in Leipzig in 1873. He studied architecture in Dresden, Munich and in Aachen, at the Technische Hochschule. At about the same time he won the competition for best design for the orphanage of Strasbourg, his designs for the 
construction started in 1907 and ended in 1909, conveyed an evident desire for modernity, particularly in the design of the main structure, which favoured good ventilation, circulation, openness and greenery. $12,000 \mathrm{~m}^{2}$ were given over to the main 130-m-long and 16-m-wide building, which was divided into a central body and two small annexes, with a wing and a stairway reserved to each sex, and with a large yard next to it. With its large bay windows, its southward orientation and its vast verandas, the new orphanage perfectly exemplified new public health concerns.

Illustration 2: A plan of the municipal orphanage, viewed from the front, in 1909 (AVCUS, 845 W 162, plans of the Hospice des Orphelins, c.1910). ${ }^{37}$

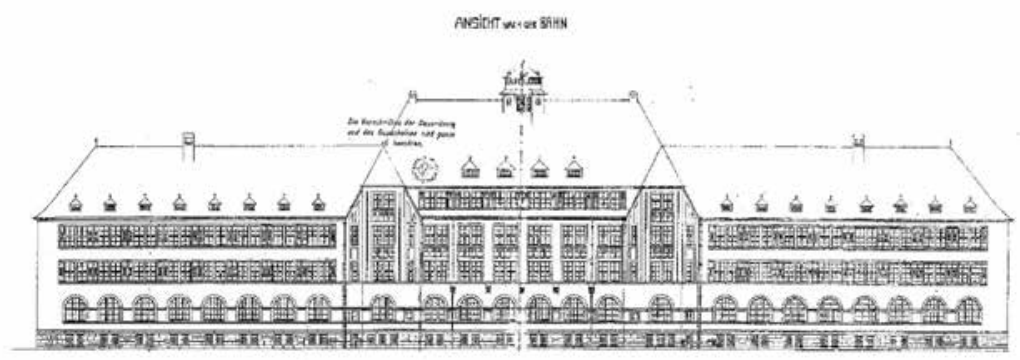

New knowledge, derived from the discovery of the part bacteria played in the spread of disease, disseminated throughout Europe and especially in Germany, attempting to solve such issues as overcrowding in urban spaces, waste disposal or water pollution. ${ }^{38}$ These ideas, developing in medical circles, also influenced social policies, urbanism or architecture. It can be noticed that the architectural language favoured

Business School of Cologne and the municipal theatre of Hagen were also selected; these buildings are still visible today. He was appointed Professor für Städtebau, Siedlungswesen und Kleinwohnungsbau at the Hanover Technische Hochschule in 1919. He was a member of the Bund Deutscher Architekten and the author of several books about architecture. He died in Hanover in 1950.

37 Archives of the city and the urban community of Strasbourg (AVCUS), $845 \mathrm{~W} 162$, plans of the Hospice des Orphelins, c.1910.

38 Good surveys about the question include Jean-Pierre Goubert, Une histoire de l'hygiène: eau et salubrité dans la France contemporaine (Paris: Fayard/Pluriel, 2011); Calixte Hudemann-Simon, La conquête de la santé en Europe, 1750-1900 (Paris: Belin, 1999) and Georges Vigarello, Histoire des pratiques de santé: le sain et le malsain depuis le Moyen Âge (Paris: Éditions du Seuil, 1999). 
by Vetterlein was used for other types of healthcare buildings: the sanatoriums, which sprang from the same conceptions of public health (ill people were to be treated through exposure to sun, light and air), were equiped with verandas similar to those the orphanage boasted at the time of its inauguration in $1910 .{ }^{39}$

Illustration 3: The veranda of a sanatorium and a back view of the municipal orphanage and of its veranda. (Personal collection of Christian Pfeiffer, 1950). ${ }^{40}$

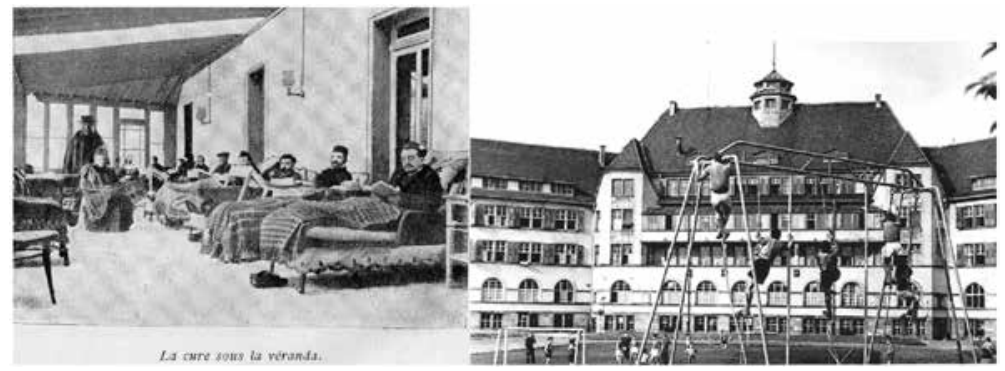

Even when it came to interior furnishings, the building proved very innovative. The orphanage was one of the first buildings in the city that could boast equiped bathrooms.

Illustration 4: The bathrooms of the orphanage (Personal collection of Christian Pfeiffer, 1950). ${ }^{41}$

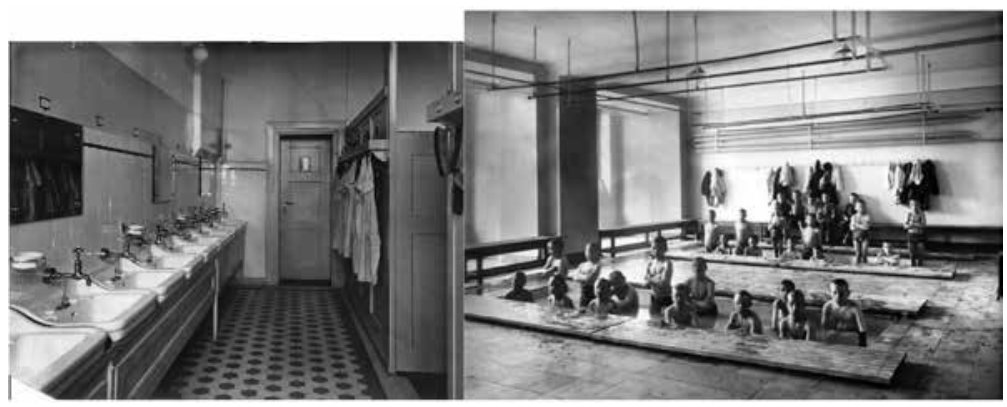

39 About sanatoriums, see Philippe Grandvoinnet, Architecture thérapeutique - Histoire des sanatoriums en France (1900-1945) (Paris: Métis Presses, 2014).

40 Left, ancient postcard of the sanatorium of Vernet-les-Bains (Pyrénées-Orientales); right, the courtyard of the municipal orphanage (the photograph is from the personal collection of Christian Pfeiffer, the ancient president of the Association des anciens élèves du foyer Charles Frey), c. 1950.

41 Photographs from the personal collection of Christian Pfeiffer, c. 1950. 
How can this very modern building be connected to Alsace's peculiar geopolitical situation?

From the beginning of the German annexation and onward, authorities had emphasized 'their significant amount of investments in order to show Alsatians what an enviable situation was allotted to them as citizens of the German Empire,42 a much better situation than they would have had under French control. The same concern was visible in other border regions or in regions where German presence had to compete with another area of cultural and linguistic influence. Such was the case in Posen (modern-day Poznan) for example, in the Prussian province of Posnania, where Wilhelm II used Joseph Stübben's designs to stamp his mark on the city in a bid against Polish influence. ${ }^{43}$ Strasbourg itself inspired ambitious urbanistic programs, along with a flurry of architectural activity aiming at Germanizing the urban landscape. ${ }^{34}$ The same policy was carried on by the successive city authorities, more particularly by Rudolf Schwander, who became mayor in 1906 - the time when the orphanage was built, with total funding from the city. In a society that was becoming increasingly medicalized, there was also the desire to modernize healthcare locations and 'municipal investment was nowhere as important as in Alsace-Lorraine... In Strasbourg, the city itself funded the construction of many new services that opened between 1906 and 1914.45 In a period of economic prosperity, the capital of the Reichsland thus found the financial means that were necessary to make sure orphans benefited from the city's policy of urban regeneration but also from the improved healthcare programs.

Though such intervention was particularly intense in Strasbourg, it was also visible elsewhere in the Reichsland. In Mulhouse and Colmar monumental orphanages thus appeared, striving to comply with the new health principles. The orphanage Saint-Joseph in Mulhouse was admittedly located in an ancient castle, but at the beginning of the twentieth century an entirely new building was adjoined to it, which sheltered near to 170 orphans in May 1911.

42 Vogler, Histoire culturelle de l'Alsace, 354.

43 Kaiserschloss Posen - Zamek cesarski w Poznaniu. Von der 'Zwingburg im Osten' zum Kulturzentrum 'Zamek' - Od pruskiej 'warowni na wschodzie' do Centrum Kultury 'Zamek', Catalogue d'exposition (Potsdam - Poznań, Stiftung Preußische Schlößer und Gärten Berlin-Brandenburg - Centrum Kultury Zamek w Poznaniu, 2003).

44 Bernard Vogler, Histoire culturelle de l'Alsace du Moyen Âge à nos jours: les très riches heures d'une région frontière (Strasbourg : La Nuée Bleue, 1996), 354.

45 Olivier Faure, 'Municipalité et hôpitaux dans les villes françaises au XIXème siècle', in Jacques-Guy Petit and Yannick Marec, eds., Le social dans la ville en France et en Europe (1750-1914) (Paris: Editions de l'Atelier, 1997), 63-74, 71. 
Illustration 5: The orphanage Saint-Joseph in Mulhouse. (Personal collection of Christian Pfeiffer, 1950).

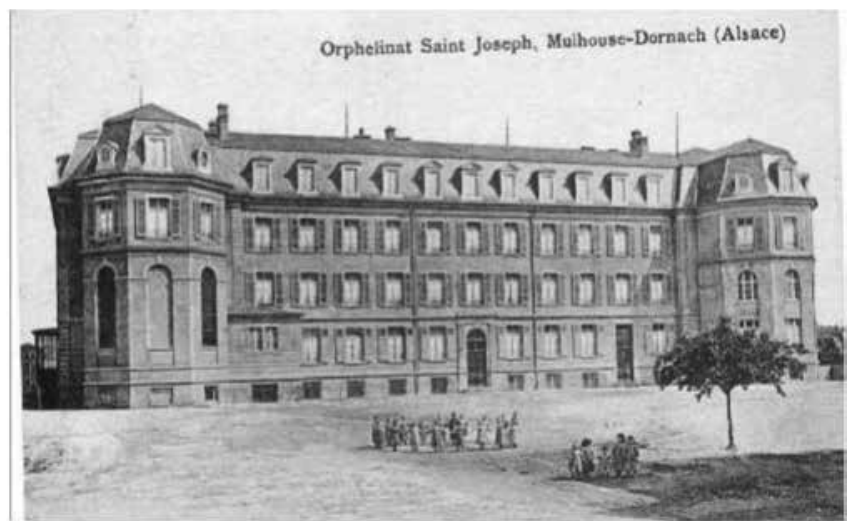

Great attention was paid to the sunlight, the height and ventilation of the building, its openness to the outside and its southward orientation. ${ }^{46}$ The orphanage of Colmar was built in 1907 by Edouard Spittler, an architect who was mainly famous for his school designs. The imposing building, which was inaugurated on 4 July 1910, was also attentive to the new health concerns, even if its style, which can be linked to the regionalist school, was different from that of the Strasbourg orphanage. ${ }^{47}$

Illustration 6: The ancient orphanage of Colmar. (Personal collection of Christian Pfeiffer, 1950).

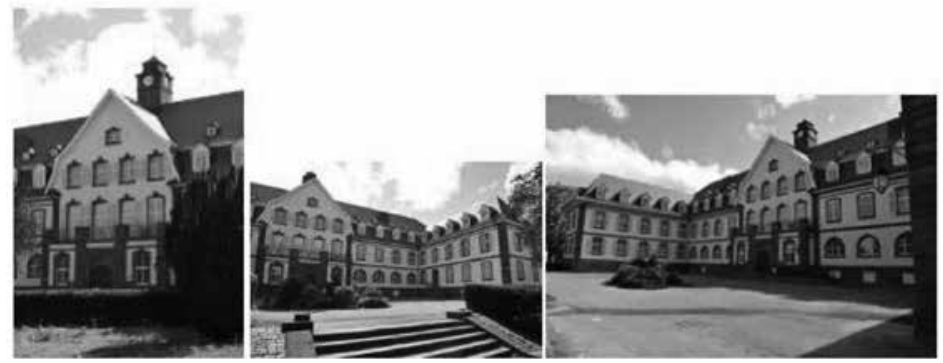

46 Orphanage Saint-Joseph, Mulhouse-Dornach, 1920. It has become the Maison d'Enfants à Caractère Social, and was acquired in 1899 by the sisters of the congregation of the Very Saint Saviour of Niederbronn.

47 The orphanage has been converted into housing estates by the Office Public d'Aménagement et de Construction. 
After Alsace came back to France in 1919, health imperatives were not forgotten, as can be seen in the case of the municipal orphanage of Strasbourg: 'during the year 1934, in order to complete the action of the Hospice des Orphelins, the administrative commission of the Hospices Civils ('Civil Hospitals') acquired a house in Saverne, near the forest... which was used as a holiday house for the residents of the Hospice. ${ }^{48}$ Before that, the children were sent to different private homes, depending on the available room, but with the 1934 acquisition, they were all able to have a little holiday to 'regenerate and repair themselves by breathing the pure air of the Vosges' ${ }^{49}$ Though in other parts of France children were also sent to the country, the mountain or the sea, such a practise can be related to the German Ferienverschickung and to Germans' love of the 'great outdoors.' Without more detailed studies, it is impossible to know whether the purchase of the house in Saverne sprang from a French or a German-Alsatian initiative, or if the decision owed everything to circumstances. One may yet notice that at the time the acquisition was made, the administrative commission of the Hospices civils enjoyed only limited financial means: buying the house must then have been considered as an imperative, whatever the cost. Breathing pure mountain air was certainly one of the few remedies that were then offered against tuberculosis, which wrought havoc in Europe, in borderland regions as much as elsewhere.

After studying the architectural design of the orphanage, it may be interesting to focus now on its day-to-day management, and the way it was affected by the succession of German and French influences.

\section{Day-to-day management and national influences on the borderland}

As we have seen, the orphanage had been managed by the Sisters of Charity of Strasbourg, a congregation founded in 1734, since the eighteenth century, when Strasbourg belonged to France. The sisters did the laundry and the cooking, provided medicine and nursing care. They also had to try to make the institution self-sufficient. Finally, they were in charge of instructing the residents in academic or religious knowledge, even if there were both Protestant and Catholic children: between 1904 and 1933, out of 216 resident girls, 120 were Catholic and 96 were 'Evangelical', that is to say Protestant. ${ }^{50}$

48 Herrmann, Les sociétés strasbourgeoises, 31-2.

49 Herrmann, Les sociétés strasbourgeoises, 31-2.

50 The graphs are based on the lists of the children admitted to the municipal orphanage of Strasbourg between 1904 and 1933 (AVCUS, 1260W49 and 1260W50). 
Figure 1: Religion of girls admitted in the orphanage between 1904 and 1933 (AVCUS, $1260 W 49$ and 1260W50). ${ }^{51}$

\section{Religion of the girls admitted between 1904 and 1933}

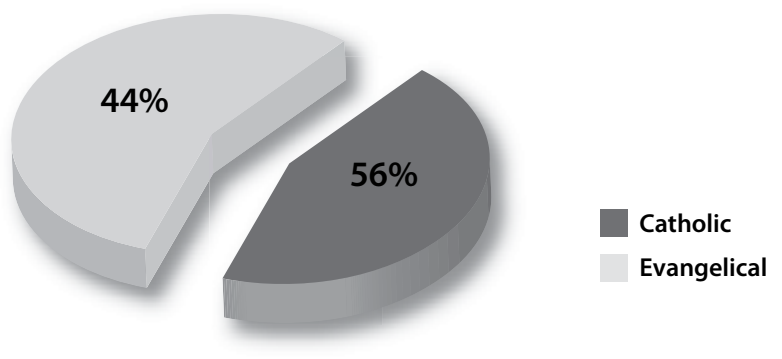

During the same period, out of 234 boys, 142 were declared Catholic and 92 Evangelical.

Figure 2: Religion of boys admitted in the orphanage between 1904 and 1933 (AVCUS, $1260 W 49$ and 1260W50).52

\section{Religion of the boys admitted between 1904 and 1933}

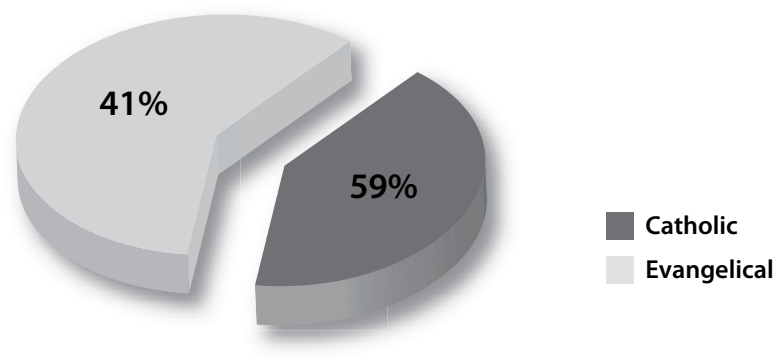

In a city in which two different faiths had coexisted since it had come back to France in 1681, the sisters were not always unanimously accepted. In the nineteenth century, they were for the first time pushed aside before being called back

51 The graphs are based on the lists of the children admitted to the municipal orphanage of Strasbourg between 1904 and 1933 (AVCUS, 1260W49 and 1260W50).

52 The graphs are based on the lists of the children admitted to the municipal orphanage of Strasbourg between 1904 and 1933 (AVCUS, 1260W49 and 1260W50). 
in $1848 .{ }^{53}$ After the German annexation, their position was never challenged, even when the Kulturkampf policy raised tensions. ${ }^{54}$ The rules of behaviour set up for the children in 1910 testify to the importance of religion in the institution. Prayers 'recited out loud by a pupil of each faith' came before each meal, the pupils could go for a walk only 'after vespers or the evening prayer' and their schedule was organized around religious practise since 'all the pupils have the duty to attend the divine offices of their respective cult on Sundays and on festivals. ${ }^{55}$ Religious instruction was also granted an essential place, since the teaching occurred every day after dinner, right before the divine office every pupil had to attend. The books that were read and directly available to the pupils were 'devotion and instruction books designed for the schools', while reading any other book 'shall not be allowed without the special and express authorization of the Director, who will guide [the children] in the choice of recreational reading. ${ }^{56}$ Concerning the period of the early 1920 s still, after the return to France, a list of the prayers to be recited during the day (one in the morning, one 'before eating', one 'after eating' and one in the evening) has been found in the archives. ${ }^{57}$

In October 1926, however, the Municipal Council decided to replace all the sisters of the orphanage with laypersons ${ }^{58} \mathrm{~A}$ few weeks after this decision, Laurent Meyer, the then adjunct to the socialist mayor Jacques Peirotes, delivered a speech providing us with some explanations. First, he deemed it inadmissible that the children, who were attending an interfaith school, should 'within the [orphanage] receive a separate education depending on their faith. ${ }^{39} \mathrm{He}$ also remarked that 'the

53 Sophie Ehret, Entre rupture et entente avec la ville : la congrégation des Sœurs de la Charité de Strasbourg de 1914 à 1945, Master's degree thesis, under the supervision of Catherine Maurer, University of Strasbourg, 2003.

54 The Kulturkampf policy was led in Prussia and in the German Reich from 1871 to the late 1870s. Bismark's government undertook to fight against the influence of churches, especially the Catholic Church, on society through legislative means. Congregations were particularly targeted but those that participated in social care institutions, like the Sisters of Charity of Strasbourg, were spared.

55 AVCUS, 1720W56, Copy of the rules of behaviour for the pupils of the orphanage, 1910.

56 AVCUS, 1720W56, Copy of the rules of behaviour for the pupils of the orphanage, 1910.

57 AVCUS, 1720W11, List of the prayers for the children, c. 1920.

58 AVCUS, 71MW205, Extract from the minutes of the meeting of the commission des hospices civils held on 11 Oct. 1926.

59 AVCUS, 71 MW 205, Report of the Municipal Council. Communication from the administration (9 Nov. 1926). Speech of Laurent Meyer, adjunct to the socialist mayor, 
sisters were appointed by the Monastery without previous examination of their special aptitude by the Direction of the Orphanage or by the Administration, ${ }^{30}$ even as they were trained in the care of the sick much more than in the education of children. These arguments had probably already partly been laid by a report destined to the administrative commission of the hospices civils that the orphanage depended on, which pointed out that 'a person in sufficient command of the French language' was needed and that 'the education of the young girls of the orphanage who have left school leaves much to be desired. The report suggested replacing the Sisters of Charity with trained staff,' with solid scientific, educational and domestic knowledge. ${ }^{61}$

The goal was thus to lead the previous evolutions to their logical outcome: an entirely secular management: 'the secularization of the institution [is] [...] the natural consequence of the interfaith evolution of schools. The point was not to 'thwart the religious needs of the orphans' ${ }^{62}$ but total secularization would help fill in certain gaps, lead to a more 'homogeneous' management and put the staff more directly under control of the administration. These were rather classical arguments, a staple of the socialist rhetoric used by Meyer or Peirotes, in the line of that used by the Republicans under the Third Republic. ${ }^{63}$ They were nevertheless rather original in the newly French Alsace, and they raised fierce oppositions, at a time when Alsatian Catholics, supported by many of their peers throughout France, had just prevailed over Edouard Herriot's government's decision to put an end to the Concordat, which had survived during the German annexation. ${ }^{64}$

There is nothing to surprise us in such an opposition from the congregation ${ }^{65}$, but the reactions of ancient residents are particularly telling. On 5 October, several

in response to M. Trebus, radical-socialist, about the dismissal of the catholic sisters attached to the orphanage.

60 AVCUS, 71 MW 205.

61 Letter of the delegate of the orphanage to the administrative commission of the hospices civils ( $1^{\text {st }}$ Sept. 1926), quoted in Ehret, Entre rupture et entente avec la ville, 100.

62 AVCUS, 71 MW 205.

63 See Catherine Maurer, La ville charitable. Les œuvres sociales catholiques en France et en Allemagne (Paris: Editions du Cerf, 2012), 286-90.

64 For more detail, see Vogler, Histoire politique de l'Alsace, 229-30.

65 The Superior of the Congregation, Father Lutz, said he was 'sadly surprised by such a brutal measure which nothing seems to justify in his opinion', letter dated 4 Oct. 1926, to the president of the administrative commission of the hospices civils, quoted in Ehret, Entre rupture et entente avec la ville, 101. 
former boarders wrote to the mayor to express their 'intense emotion'. They insisted on the 'deep gratefulness and the intense sympathy' they felt for the sisters who had been managing the orphanage for more than a century: 'The administration, as well as the Director, the author of this project, should know about the devotion, the abnegation of the good sisters and the popularity they enjoy among the population of Strasbourg. They asked for the preservation 'in this ancient institution of Strasbourg of the high morality of the Sisters which has constituted the mainstay of this house for generations. ${ }^{66} \mathrm{~A}$ little later, a woman named Lucie Biedermann wrote on behalf of the orphaned girls to draw attention to the 'most tender care' they had received from the Sisters whose 'love' and 'maternal goodness' cannot be questioned, and who 'infuse into young souls [a] reflection of [their] truly charitable heart. ${ }^{67}$ The orphans, 'who have no support whatsoever in the world', are resenting the dismissal of their 'Consolating Angel[s], [their] darling mother[s] who took [them] under [their] protection', which 'bereaves them for a second time.68 ${ }^{68}$ The Catholic press also stood by the sisters and described their dismissal as a 'shame on Strasbourg' ${ }^{69}$ or as an example of 'the hate-based policy devised by the Municipal Council. ${ }^{70}$

The decision of the Municipal Council was nevertheless not overturned, and the sisters had to leave the orphanage, whereas in other French cities, they kept their position in civil social institutions. The episode shows that though the evolution of the management of the orphanage was certainly linked to national influences, in this specific case, it had much more to do with Meyer's and Peirotes's ideological orientation, added to issues related to qualifications and individual personalities, than with Strasbourg's specific borderland situation. Did this situation, though, have any influence on the way issues related to the nation were apprehended inside the orphanage?

66 AVCUS, 71 MW 205, letter from the ancient pupils of the hospice des orphelins de Strasbourg Neudorf to the Mayor of Strasbourg, M. Peirotes, 5 Oct. 1926.

67 Letter from Lucie Biedermann (5 Nov. 1926), to the Mother Superior of the Congregation of the Sisters of Charity, archives of the Congregation of the Sisters of Charity, quoted in Ehret, Entre rupture et entente avec la ville, 182.

68 Letter from Lucie Biedermann.

69 AVCUS, 71 MW 205, title of an article published on 12 Oct. 1926 in Der Elsässer.

70 AVCUS, 71 MW 205, title of an article published on 30 Oct. 1926 in Der Elsässer. 


\section{Borderland situation and national issues inside the orphanage}

The change from belonging to one nation to another was first translated in Alsace by a change in languages, at least from an official point of view. The succession of official languages is visible in the records left by the orphanage after the First World War, more particularly in the enrollment records. They brutally switched from German to French in 1919 and, out of 104 young girls enrolled between 1919 and 1933, only two had German-sounding names (Frida and Augusta) whereas until 1918 the girls' first names were usually equally divided between 'French' and 'German' names. There was thus a clear desire to adapt the language to the new status of Alsace, even if bilingualism remained a reality, as can be seen in the records of the interwar period. ${ }^{71}$

In an institution in which day-to-day management mattered necessarily more than more abstract considerations, it is difficult to find testimonies or documents dealing with the sense of national belonging. Mention can be made of a passage taken from a magazine published by the city of Strasbourg during the First World War, presenting the orphanage. ${ }^{72}$ It is said that despite the requisition of the place by the army, the children, who were transfered to a building that was too small for them in the north of Strasbourg, 'have enough clothes and shoes', are surrounded by 'people [...] [who] do their best [to] subtitute themselves to the love of a mother or a father' and 'are much better than a thousand other children who are not orphans. ${ }^{73}$ The propaganda is obvious but patriotic feelings seem to have indeed been shared in the orphanage: 'The war threat [...] first gave rise among the apprentices to feelings of national enthusiasm, expressed through word and song, which were all the more admirable as they arose spontaneously and were not dictated by any superior exigencies. ${ }^{74}$ This shows that the young boys of the orphanage seem to have taken the side of Germany without being particularly aware of their borderland situation.

Things were different in the interwar period, especially at the end of the 1930s. In a radio speech delivered on 26 December 1937 to the children of the orphanage, the director Henri Will staged a dialogue between himself and the child Jesus, come back among men on Christmas day. To the director's complaint about the expensive cost of living, the child Jesus replied:

71 Ripplinger, L'orphelinat municipal du Neudorf, 161-2.

72 AVCUS, 71 MW 82, Henri Will, 'Das städtische Waisenhaus während der Kriegszeit', Blätter für das Strassburger Armenwesen, c. 1915, 213-5, translated from the German.

73 AVCUS, 71 MW 82.

74 AVCUS, 71 MW 82. 
Have you never thought about the place where you would be celebrating Christmas if the war had broken out? You do well know that you would never have been able to remain in your beautiful orphanage... and that you would have had to leave with your 300 children and travel on the roads and on the train...meeting cannons, trucks, tanks and war machines on the way! ${ }^{15}$

These words foreshadow the planned evacuation of the orphanage in September 1938, when the Nazi claims on Czechoslovakia precipitated an international crisis that was only temporarily defused by the Munich Agreement. There was then great alarm among the former residents of the orphanage, as certain letters show. 'We hear once again the same serenade and this time, it seems worse than before. There are serious talks of war. Is the worst to be feared in Alsace too? ${ }^{36}$; another one asks: 'Will Strasbourg be evacuated? What shall happen to the children who are so many?'77 Another one mentions 'the days of sadness and anguish when our youth was being threatened with destruction', which was avoided thanks to 'great men' such as 'Daladier ${ }^{78}$. Poems in Alsatian, disseminated in Lami des Orphelins, also convey a certain form of patriotism, especially centered on the Heimat, the 'little homeland.' ${ }^{9}$

Even though the small number of sources should invite us to remain cautious, it seems that during the 1930s Alsatians became much more aware of their borderland situation and that they transferred their patriotic feelings away from the nation onto the Alsatian 'little homeland', announcing evolutions that would be more visible from the end of the 1960s onward. An indirect confirmation of this is provided by the fact that, during the same period, the orphanage of Strasbourg established links with the orphanage of Lille, which also depended on the city's Hospices Civils. Meetings were organized; for instance, orphans from Lille visited Strasbourg at the end of August 1935. The children were 'delighted' by such exchanges, by the 'lovely welcome' and the

75 Henri Will,'Ansprache des Waisenhausdirektors für Weihnachten im Waisenhaus', L'ami des orphelins, 1938, 1. L'ami des orphelins is a magazine published by the municipal orphanage of Strasbourg from 1936 on.

76 Letter dated 23 Sept. 1938, L'ami des orphelins, 1938, 4.

77 Letter dated 26 Sept. 1938, L'ami des orphelins, 1938, 4.

78 Letter dated 3 Oct. 1938, L'ami des orphelins, 1938, 4. Edouard Daladier was Président du Conseil (the leader of the government) between 1938 and 1940 and as such signed the Munich Agreement.

79 L'ami des orphelins, 1938, 2. 
'gracious and friendly hospitality'80 they enjoyed in the Alsatian capital. These are the only recorded relationships between the orphanage of Strasbourg and another such institution and, perhaps significantly, it was also a borderland place, although it probably did not have to face such issues concerning national identity as the Strasbourg orphanage.

We thus think that looking into the way orphans were cared for in Strasbourg in between the German annexation at the beginning of the twentieth century and the return to France during the interwar period makes it possible to study issues closely related to the subjects of the borderland and the sense of national belonging. First, we have had to tackle the leglislative and administrative framework, and the effects geopolitical changes had on it: the Hospice des Orphelins, as it was still called in the 1930s, was the heir of a long history, starting in a Germanic context in the Middle Ages, extending throughout the first French period, in between 1681 and 1870, and the German period between 1871 and 1918, and finally undergoing two different transitions from Germany to France and France to Germany in the twentieth century, if we take 1940 as a stopping point for our presentation. It was possible for the institution to remain in the same space, the borderland, and to pursue the same field of activity, child care, although both space and activity were very strongly affected, in the region and the time, by important changes. A closer look at the legislative and administrative underpinnings of the orphanage brings to mind Tancrède Falconeri's famous phrase, in Giuseppe Lampedusa's The Leopard, 'everything must change so that everything can stay the same', and would seem to make of it an 'Alsatian' exception. A study of its architectural design would rather seem to qualify such a view: new health concerns and new priorities penetrated the institution and Germany's dynamic action in that field could seem to contrast with French traditions. Child care institutions were also affected by architectural modernization, in the borderland maybe more than elsewhere, fueled by Germany's desire to compete with its near neighbour. In the absence of more systematic studies on the architecture of child care institutions, we should nevertheless remain cautious. As for the day-to-day management of the orphanage, it was far from free of political and ideological considerations, but these were only partly linked to the borderland situation. Finally, in the 1930s at least, in a period of intense international tensions, awareness of their borderland status clearly rose among the managers and the boarders, but it seems to have strengthened a sense of belonging to the Alsatian 'little homeland'

80 AVCUS, 1720 W 33, Correspondance between the hospice des orphelins de Strasbourg and Lille orphanage, between 14 Sept. 1933 and 22 July 1935. 
rather than to the 'great nation' of France. The approaches could be numerous and would undoubtedly need further study but we think that these outlines for a microhistory of subjects that have for a long time been neglected, particularly in Alsace, that is to say childhood and borderland areas, could provide useful elements for larger historiographical perspectives on such questions as conflicts and nationalisms in the twentieth century. 


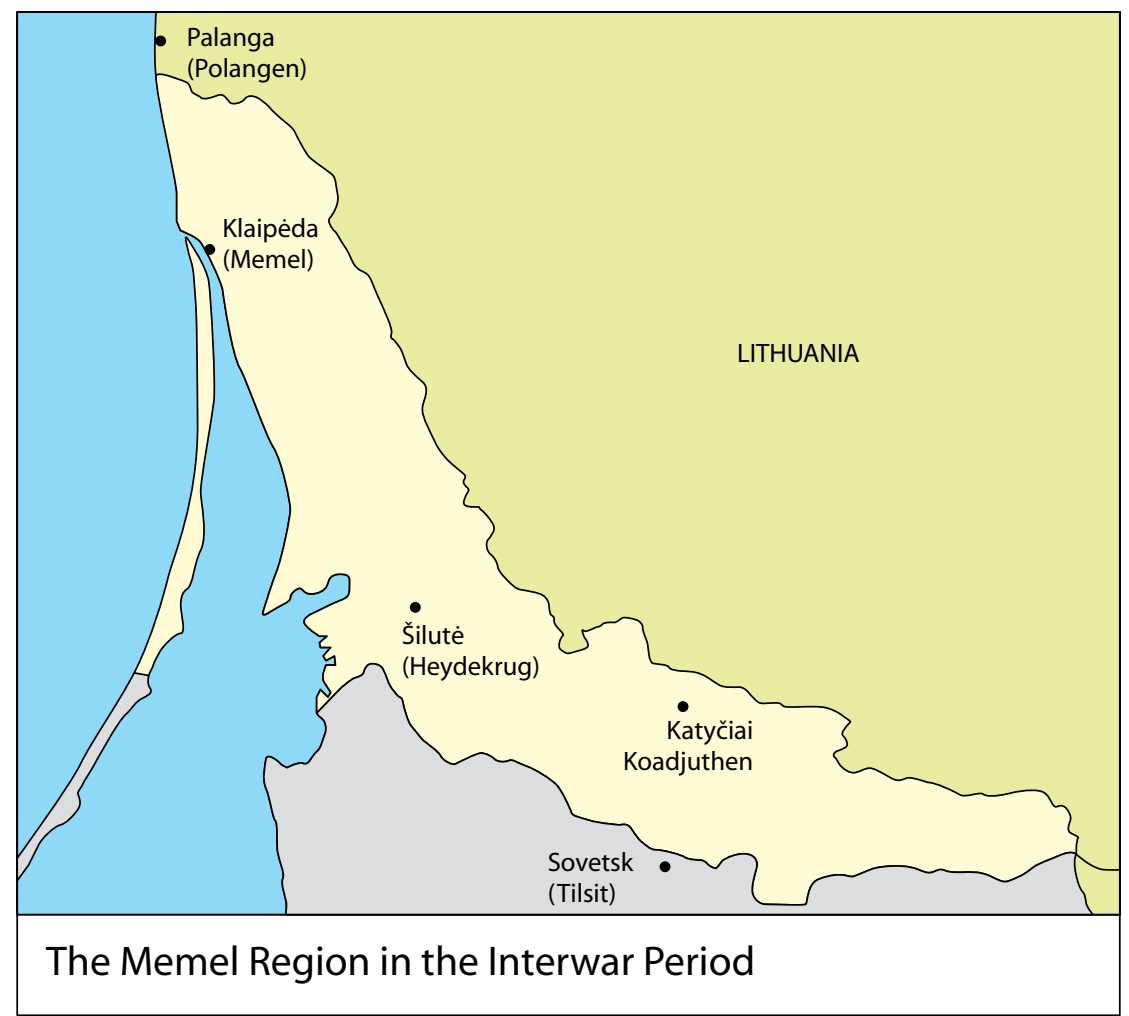

Map 3: The Memel Region in the Interwar Period. 


\title{
Ruth Leiserowitz \\ Childhood in the Memel Region
}

\begin{abstract}
The designation 'Memel Territory' was coined in 1919 at the peace conference in Versailles, referring to the northern strip of East Prussia, bordered on the south by the Memel River and extending to the village of Nimmersatt (Nemirsate) on the Baltic coast. Article 99 of the Treaty of Versailles in the end stipulated the cession of the Memel Territory from the German Reich. After the Lithuanian militia had achieved a fait accompli on January 15, 1923, the Entente Powers and Lithuania held tense negotiations that led to the Memel Convention of May 8, 1924. The Convention guaranteed Memelland extensive autonomy within the Republic of Lithuania. Between 1920 and 1937, Memel comprised a region with a German cultural and economic life; the autonomous authorities undertook no anti-Semitic measures whatsoever until 1937. Germany re-incorporated the Memel Territory on March 22, 1939 after forcing an ultimatum on the Lithuanian Foreign Minister Juozas Urbšys. In the region, the majority of the children received a good education. The only area where German, Lithuanian, and Jewish children encountered each other was in school. Children were very active in their leisure time - particularly in sports and in Scouts - regardless of their national affiliation. All the children in the region, Germans, Lithuanians, as well as Jews, were affected by the territorial conflicts and the war. These things unexpectedly and abruptly ended their childhood. This paper examines the memories of different children. It seeks to show that the majority of parents, regardless of their national and political background, tried to secure for their children an apolitical and protected childhood.
\end{abstract}

\section{Introduction}

The paper that follows deals with the experiences of childhood in the GermanLithuanian border region. This was an area that lost its original national affiliation as a consequence of the First World War, being administered during the interwar period as having a minority status. The Memel Region (as did many other border regions in the 20th century) had a quite varied history. The designation 'Memel Territory' was coined in 1919 at the peace conference in Versailles, referring to the northern strip of East Prussia, bordered on the south by the Memel River and extending to the village of Nimmersatt (Nemirsate) on the Baltic coast. Article 99 of the Treaty of Versailles in the end stipulated the cession of the Memel Territory from the German Reich. The territory had an area of 2,416 square kilometres and 141,000 inhabitants in 1919. After the Lithuanian militia had achieved a fait accompli on January 15, 1923, the entente powers and Lithuania held tense 
negotiations that led to the Memel Convention of May 8, 1924. The Convention guaranteed Memelland extensive autonomy within the Republic of Lithuania.

Germany and Lithuania considered the situation temporary. Germany endeavoured to secure the territory's permanent repatriation; Lithuania, on the other hand, wanted to fully integrate the region into its state. Meanwhile, the city attracted new residents with the number of inhabitants growing rapidly. The steady influx of Lithuanian Jews underscored the economic and cultural gap between the Memel Territory and Lithuania.

For reasons of length, the following study is limited to just the time period of the 1930s. The focus will be on the recollections of various children living in the Memel Region during the interwar period. The recollections of persons have been chosen from those who were born in the period between 1920 and 1932 and who grew up in various social milieus. ${ }^{1}$ Childhood in this region was experienced in many different ways and independently of one's social background. If in the village a 'childhood on the streets' was the most prevalent and characterized by its emphasis on unmonitored cliques and games, in the city an 'at home' form of childhood within the family was in the process of developing. ${ }^{2}$ This development had the consequence that the children in the city were purposefully kept at a distance from political hot topics, while the children in the countryside were more likely to share in the experience of the tensions that were surfacing within the society and they consequently became witnesses of the surrounding events.

\section{Sources and Research Position}

The author himself has worked on the history of this area and conducted interviews with Memellanders in Lithuania during the period 1990-2001. Until now only life stories of the post-war period from these interviews have been published. ${ }^{3}$ Further examination of the interviews has shown that the interviewees idealized their pre-war period of childhood to a great extent. The author intended to show different designs of childhood in the country within a geographical context. The memories reported by eyewitnesses in the publication of Günter Uschtrin

1 Jürgen Zinnecker, 'Kindheit und Jugend als pädagogische Moratorien: Zur Zivilisationsgeschichte der jüngeren Generation im 20. Jahrhundert', in Bildungsprozesse und Erziehungsverhältnisse im 20. Jahrhundert, ed. Dietrich Benner and Heinz-Elmar Tenorth, Zeitschrift für Pädagogik, Beiheft 42, 36-68 (Weinheim: Beltz, 2000), 38.

2 Ibid., 44.

3 Ruth Kibelka, Memellandbuch. Fünf Jahrzehnte Nachkriegsgeschichte. 1. Aufl. (Berlin: Basisdruck 2002). 
complete the existing sample quite well. ${ }^{4}$ However, the related interviews were again compared with other printed memories. ${ }^{5}$ The sources of the Jewish witnesses were raised in a project that the author carried out from 2001 to 2006 and also led to a publication. ${ }^{6}$ In the analysis, only memories submitted by witnesses who were born between 1920 and 1932 were included. Younger interviewee had no clear memories of the school in the bilingual Memel. In the two interview series mentioned, people born in the years 1904, 1910 and 1914 also participated, but no content has been included in the analysis. The oral history sources were of great importance, because through them facts could be stated for which there was no evidence to date. The history of Memel is now considered relatively well known; the aspect of childhood was illustrated but never analysed. ${ }^{7}$

\section{Historical Background}

Prior to the First World War, the slender region north of the Memel River was considered so unimportant that it had not even been designated with a name yet. It was closely affiliated with East Prussia and had comprised since 1871 the very northern tip of the German Reich. The residents in the area spoke several different

4 Günter Uschtrin, Wo liegt Coadjuthen? Die Geschichte eines ostpreußischen Kirchspiels im ehemaligen Memelland, ed. Günter Uschtrin, 1., neue Ausg, 334-5 (Berlin: Berliner Wissenschafts-Verlag, 2011), 334.

5 Hans Paltins, 'Wenn Lehrer Bajorat in den Graben fuhr...'Erinnerungen an Deegeln und seine Schule. In: Memeler Dampfboot, 20.12.1972; Lachauer, Ulla: Ostpreussische Lebensläufe. (Reinbek bei Hamburg: Rowohlt 1998) Jurkschat, Christine: Brot und Salz. Das ungewöhnliche Schicksal eines jungen Mädchens : Erinnerungen. (Norderstedt: Books on Demand GmbH 2005).

6 Ruth Leiserwowitz, Sabbatleuchter und Kriegerverein : Juden in der ostpreußischlitauischen Grenzregion 1812-1942. Osnabrück: fibre 2010 (Einzelveröffentlichungen des Deutschen Historischen Instituts Warschau / Deutsches Historisches Institut, Warschau).

7 Vytautas Žalys, Kova dèl identiteto: kodèl Lietuvai nesisekè Klaipèdoje tarp 1923-1939 m.-Ringen um Identität: Warum Litauen zwischen 1923 und 1939 im Memelgebiet keinen Erfolg hatte: Lüneburg: Nordostdeutsches Kulturwerk 1993 Tauber, Joachim (2001): Das Memelgebiet (1919-1945) in der deutschen und litauischen Historiografie nach 1945. In: Nordost-Archiv. Zeitschrift für Regionalgeschichte NF X, 11-44; Vareikis, Vygantas (2001): Memellander/Klaipediškiai Identity and German-Lithuanian Relations in Lithuania Minor in the Nine-teenth and Twentieth centuries. In: Sociologija. Mintis ir veiksmas (1-2),7; Safronovas, Vasilijus; Nikžentaitis, Alvydas; Staliūnas, Darius; Čepaitiené, Rasa; Lopata, Raimundas; Valantiejus, Algimantas; Vareikis, Vygantas et al.: The Competition of Identity Ideologies in a City of South-Eastern Baltic Sea Region: The Case-Study of Klaipeda in the 20th Century. (Klaipeda: Klaipedos institutas, 2012). 
languages, a common reality on the eastern edges of Prussia. On the other side of the border, Lithuania extended outward; it had been incorporated into the Russian Empire in 1795 and was generally referred to as Russian Lithuania. The Lithuanians on either side were different from one another in several ways. The Prussian Lithuanians were Protestant and used Gothic script. On the other side of the border, the Lithuanians attended Catholic churches and used Latin script. During the First World War, East Prussia was the only German region drawn directly into the suffering of the war. The Memel region also experienced the incursions of Russians and the carrying off of civilians. On February 16, 1918, an independent Lithuanian Republic was proclaimed in Vilnius. From the perspective of those in Germany, the situation seemed like this: in place of an economically important empire as its neighbour, there was now a small mini-state on the other side of the border that could not even be assigned to a political category and, moreover, it appeared to be totally unstable. East Prussia had suffered the loss of its economically powerful neighbour and consequently lost its role as an economic hub.

In the treaty of Versailles, without any consultation with the populace, the East Prussian region north of the Memel was separated from Germany with the justification that it was primarily Lithuanians who lived in the area. Thus tolled the hour of the birth of an artificial construct: Memelland (or the Memel region). The region was placed under French administration, which however represented an interim solution. In January 1923, the Republic of Lithuania occupied the neighbouring region and the French withdrew. The Allies thereupon issued in 1924 what was called the Memel Convention, which said that this region within the Republic of Lithuania must be afforded an autonomous status. From the perspective of international law, this convention served as the determinate constitutional basis for the territory. Simultaneously, a Memel Statute was put into effect, laying out the implementation of the convention. Minority rights in the area were to be guaranteed.

The Lithuanian government, when setting up the new administration, did not rely on the workforce in the region itself, but instead, brought along its own clerks. Memelland started to appear quite attractive to outsiders for economic reasons. Nevertheless, the city of Memel itself continued to have a predominantly German character. However, in an effort to reduce the percentage of Germans in the population, the Lithuanian government (among other things) promoted the settling of Jews there, who moved into the region in large numbers. The city attracted Lithuanian Jews. The living standard was higher and the Lithuanian policy of nationalization was less firmly enforced. In comparison with Germany, the Jews 
also felt relatively safe after 1933 because there was no public antisemitism here, at least until 1938.

The city and the harbour prospered; however, famers in the countryside had to struggle with enormous difficulties in selling their products. The Kaunas government had developed no real policy for incorporating the annexed territory; consequently, the dissatisfaction of the Memellanders grew. After Hitler came to power, the German-Lithuanian conflicts over Memelland intensified and formally a state of war existed in the region. After it ended, there were elections for a Memelland parliament, and these resulted in December 1938 in an overwhelming victory for the German list of candidates, with the consequence that Jews began to immediately flee from the region. On March 21,1939, the Lithuanian foreign minister, Juozas Urbšys, was forced to sign a German ultimatum regarding the return of Memelland. Immediately after the re-incorporation of the region, the German government announced a law according to which any Memellanders who had become Lithuanian nationals on July 30,1924 , and who had their residence in the Memel Region or in Germany on March 22, 1939, received back their German citizenship. In this way, after the annexation, all the residents of the Memel Region again became Germans unless they opted by the end of the year to remain Lithuanian, pursuant to a regulation that the German and Lithuanian government had negotiated in that same year.

The Jews left the Memel area within a very short time. Many of them were killed in Lithuania in 1941-1943. Meanwhile, Lithuanians went back to Lithuania. The use of Lithuanian was forbidden in public. The Second World War started just six months later. In the Memel region population displacement was a process that closely intertwined the Nazi (forced evacuation of 1944) and Soviet practices of dealing with the population. First, the Germans had evacuated the city population of Memel. Nearly nobody returned after 1945. Therefore, after the war the city could be sovietised without much resistance. The rural population of the region was forced to leave later. More than 10,000 Memellanders began their return to the Memel region after the end of the war. The region officially became a part of the Lithuanian Soviet Socialist Republic. Lithuanians and other Soviet citizens were settled here. About the population figures of the postwar period in the region there are only estimates. Borders of counties and districts were altered to erase the old regional border. Youth life was organized in the communist youth organization. Alternatively, youths met in church circles. The public use of German was not allowed. After the conclusion of an agreement between both German states and the 
USSR in April 1958, a total of 6,156 persons left the region. ${ }^{8}$ After the relocation of a large part of the German population in 1958 to Germany, those Memellanders left behind began to conceal their identity.

Illustration 7: After 1933 Jews flee from Germany to Klaipeda. First came those who still have roots and relatives here. Fritz Marcuse, who then became a sport teacher at 'Bar Kochba' (in the centre), was one of them. Members of the local 'Bar Kochba' in 1937 on the sports field Society "Jews in East Prussia", Archive.

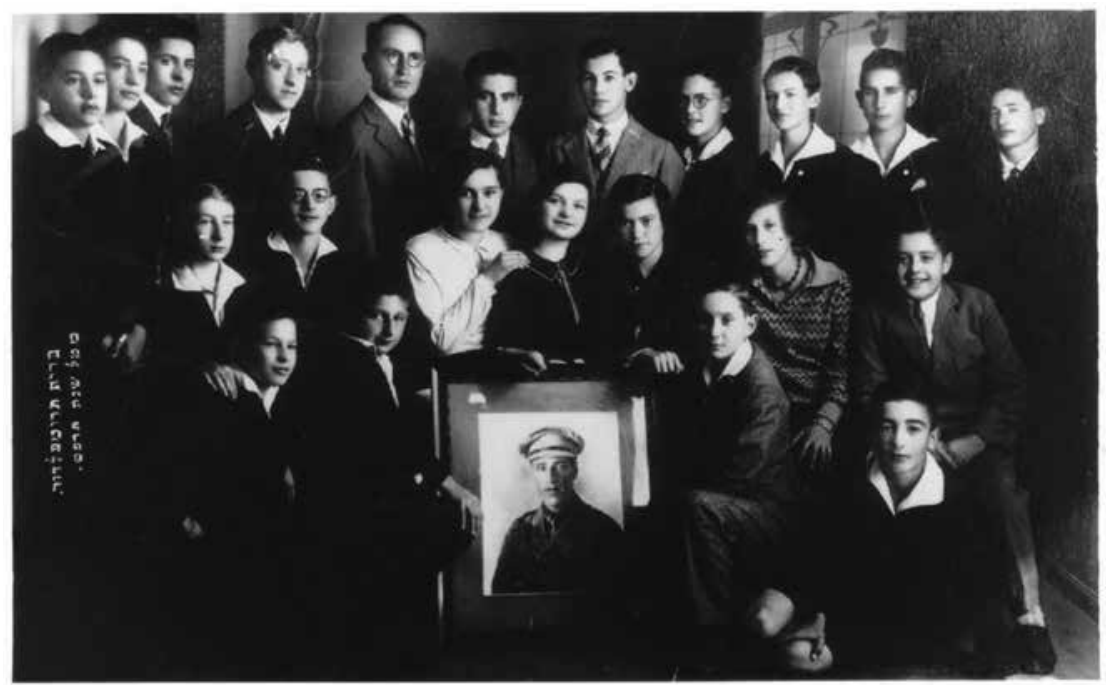

\section{Language Policies}

In response to the protest of the German government about the decision to cede the region to Lithuania, the Allies responded in a letter signed by George Clémenceau ${ }^{9}$ which contained the following passage:

The region has always been Lithuanian. The majority of the population is Lithuanian in terms of origin and language. The fact that large parts of the city of Memel itself are

8 LCVA [Lietuvos Centrinis Valstybès Archyvas =Lithuanian Central State Archive], F.R. - 754, Ap. 13, B. 693, L. 3-5.

9 George Clémenceau (1841-1929), French politician, 1917 Minister of War, 1917-20 Minister President who espoused harsh policies toward Germany at the peace conference of Versailles. 
German does not justify keeping the entire region under German sovereignty, particularly because the harbour of Memel is Lithuania's only access to the sea. ${ }^{10}$

One can read from this passage that to the writer of the letter, the differences in language usage between the region's countryside and city were evidently clear. The political weightings in the border region were changing. Memel, as a political and economic centre of the disputed border region, played a significant role in the German-Lithuanian relationship and was for almost 20 years a focus of international attention.

The young Lithuanian took great efforts in the fields of culture and education. But in the aftermath of the coup of 1926, President Antanas Smetona gradually implemented an authoritarian regime and demanded a forced nationalization of all areas.

Germany and Lithuania both sought (in equal measure) to strengthen their influence in the region. The Jewish populace in the city of Memel, being the third largest, clearly profited (until 1938) from the state of affairs existing between these two national states. In the census conducted in 1924, 59,315 residents declared themselves to be German, 37,626 as Lithuanians, and over above this 34,337 as Memellanders. ${ }^{11}$ In the interwar period, Lithuanian and German were on equal footing as official languages. The residents received Lithuanian passports with the addition 'Citizen of Memelland.'12 Between 1924 and 1939, whoever worked in local administration or state-run institutions such as the railroad or the post office, had to send their children to a Lithuanian school. Through such a regulation, mixing of the languages and cultures in the region increased. In the countryside, both languages were already spoken anyway, but in Memel there were many who could not speak Lithuanian. At a practical level, how language was used in each family was quite varied. It can however be determined that the importance of ethnicity seldom played a role in constituting dissimilar childhoods.

10 Henry de Chambon, La Lituanie moderne, (Paris: Éditions de la Revue parlementaire 1933), 83. Further to this: Joachim Tauber, Die deutsch-litauischen Beziehungen im 20. Jahrhundert, Lüneburg 1993.

11 British Empire, France, Italy, Japan, and Lithuania. Convention concerning the Territory of Memel, signed at Paris, May 8, 1924.http://www.worldlii.org/int/other/treaties/ LNTSer/1924/194.pdf (accessed June 2017 Valsonokas, Klaipedos problema, 268.

12 At the same time a process took place in which citizens had to choose either Lithuanian or German nationality. 


\section{The School System}

Children from the age of 6 to the age of 14 had to attend the school. There had always been compulsory school attendance in Memel. The elementary schools were institutions of the state. In addition, there were a few municipal and private schools.

In the city of Memel, in addition to a primary school and junior high school, there were two German secondary schools: for the young men there was the Luisen-Gymnasium and for the young women the Auguste-Victoria-Lyceum. Starting in 1923 there was also a Lithuanian gymnasium named Vytautasgymnasium, which in 1934 got a new and quite distinguished building. The elements of the school policies were determined by the Directorate of the Memelland Parliament in Memel and so were not directly subject to the government of Lithuania. The Lithuanian language, spoken and written, was a required subject in all the schools, but this subject was not taken particularly seriously by the parents (the Memel Germans as well as the Prussian-Lithuanians and the Jews). ${ }^{13}$

In December 1933, there was an order of the Governor of the Memel Territory in connection of the Lithuanian 'Law on the recruitment and employment of foreigners in the public service. A large number of teachers who worked as German citizens in schools and public services had to leave now. At the same time, the governor handed over to the President of the Executive Board a list of teachers in schools of Lithuania, from which candidates could be chosen as a replacement. ${ }^{14}$ Thereby the Lithuanian influence would be enhanced at the schools. The expulsions of teachers also meant that the National Socialist influence barely reached the Memel students.

In 1936, after various pushbacks by the Directorate on the one side (in which the school consultant Kurmis was especially involved) and of the German-oriented Jews on the other side, a Jewish primary school (Tarbut) was established following the model of the school system quite widespread in Lithuania. ${ }^{15}$ Tarbut, the Hebrew word for culture, was a synonym for secular Zionist education. The language of instruction in these schools was Hebrew. In Coadjuthen, a large

13 Günter Uschtrin, 'Die Schulen in Coadjuthen während der Memellandzeit (1919-1939), in Wo liegt Coadjuthen? Die Geschichte eines ostpreußischen Kirchspiels im ehemaligen Memelland, ed. Günter Uschtrin, 1., new edition, 334-5 (Berlin: Berliner WissenschaftsVerlag, 2011), 334

14 Memeler Dampfboot vom 18. Dezember 1933, 2.

15 Lietuvos Valstybinis Archyvas [Lithuanian State Archive] LVA, F.378, Ap.3, B. 3426, 140 (17.4.1934). 
church village on the border with Lithuania (representing here an example for the situation in the countryside), there was, as in other places in the region, a multilevel primary school for the children from age 6 to 14. After 1923, with German help and with the sponsorship of an association, a private secondary school was established which was to ease the path for gifted children to later gain admission to the German gymnasiums in Heydekrug and Memel (both requiring private tuition). In the 1930s, forceful attempts were initiated by the Lithuanian government to educate the children in the countryside into the Lithuanian cultural spirit. To this end, around 1935 a Lithuanian school in Coadjuthen was also opened, three years later also getting a new school building. A number of parents sent their children to it, because in Lithuanian schools there was no corporal punishment and because the pre-school Lithuanian kindergarten had a good reputation among the German parents. The Lithuanian teachers sought to persuade the German parents to send their children to this Lithuanian primary school. ${ }^{16}$ Both financially and materially, it was far better provided for than both of the two German schools. ${ }^{17}$ In spite of all the means at their disposal, the Lithuanian government was only somewhat able to reduce the influence of the German schools.

\section{Childhood in the Village}

In the region, there were numerous church villages where life was bustling. The inhabitants in the environs came to the weekly markets and to Sunday worship. The social position of the village residents could quickly be determined by considering the location of their residences. The most important personalities had their houses in the middle of the village; the poor lived on the periphery, frequently quite close to the forests. Among the well-to-do farmers was the Groeger family, whose daughter Erna Mehmert (nee Groeger, born in 1925) has left behind her recollections. The family of the school principal Hein likewise did so in the written experiences of their son Walter (born in 1924).

16 Walter Hein, 'Coadjuthen unter litauischer Besatzung: Ein Erlebnisbericht von Walter Hein, geb. 1924 in Coadjuthen', in Wo liegt Coadjuthen? Die Geschichte eines ostpreußischen Kirchspiels im ehemaligen Memelland, ed. Günter Uschtrin, 1., new edition, 312-4 (Berlin: Berliner Wissenschafts-Verlag, 2011), 313.

17 Günter Uschtrin,'Die Schulen in Coadjuthen während der Memellandzeit (1919-1939), in Wo liegt Coadjuthen? Die Geschichte eines ostpreußischen Kirchspiels im ehemaligen Memelland, ed. Günter Uschtrin, 1., new edition, 334-5 (Berlin: Berliner WissenschaftsVerlag, 2011), 335 . 
Erna Mehnert is able to recount: 'In Coadjuthen I am quite simply living out a carefree childhood, fully free and unencumbered. We are at home everywhere we go. For us children, every house of our friends and acquaintances was open to us from attic to cellar. We paraded happily around in clothes that we found in chests and suitcases in the attic. We do this, for example, at the uncles of my friend Mimi Hein (Franz Kestenus), who owns a brickworks and is also the director of the Lithuanian bank; at the Grigats, who ran a drugstore next to the house and whose daughter Ruth actually is a friend of my sister Lilo. The people there are generally very fond of children. ${ }^{18}$ Disputes about language policies or experiences that had a political tone do not show up in their recollections, giving the sense that they did not leave behind any appreciable impressions.

However, significant in her recollection were the social differences that were prevalent in the village and that she came to know as a child. In this case she is able to report:

However, things are not going so well for everyone. Hedwig, the best student in the upper classes and who has a voice like a lark, lives outside the village in a cottage. We visit her once and are amazed at the in which she lives. Similarly, a later school friend of ours lives in great poverty and hardship. We find this out only when a visit is scheduled for us by the school, because she lost one of her sisters who stumbled into a threshing machine. ${ }^{19}$

There were in the village, however, other children who experienced a totally different childhood, such as Franz, a son of the Lithuanian family Gauptis. In his recollections it says:

Born on April 7, 1932 in a mud-walled house with a straw roof, mud floors, and a hearth made of stone masonry; to say nothing of the furnishings: 1 table with chairs and 3 beds for 6 persons. The older siblings were already out of the house and worked for the farmer. [...] The owner of the house in which my seven siblings Emma, Georg, Martha, Fritz, Meta, Paul and I were born was the landlord Mitskus. My parents and some of my siblings had to do drudge work for him; for example, in springtime load up the manure and spread it on the fields. ${ }^{20}$

Gauptis lists other jobs such as planting potatoes and turnips, then harvesting grain as well as potatoes and turnips, and explains: 'This fieldwork was done yearly,

18 Erna Mehner, 'Erinnerungen an meine Kindheit in Coadjuthen', in Uschtrin (Hg.) 2011, - Wo liegt Coadjuthen, 443.

19 Ibid., 440.

20 Franz Gauptis, 'Meine Jugendjahr in Medischkehmen', in Wo liegt Coadjuthen? Die Geschichte eines ostpreußischen Kirchspiels im ehemaligen Memelland, ed. Günter Uschtrin, 1., new edition, 465-8 (Berlin: Berliner Wissenschafts-Verlag, 2011), 465. 
as so-called rent for the one large room in the mud-walled house. ${ }^{21}$ He explains this further:

By the time I was five years old, I also had to do some limited jobs; in the fall I herded up around 60 to 70 cows. In the early morning, the farmhands and maids who also had to work for the farmer took me (the whippersnapper) out to the meadow, about 7 to 8 kilometres distant from the village of Medischkehmen. Out there they left me alone with the animals. Sometimes when there was a thick fog, I could hardly see my hand in front of my face, while constantly walking back and forth in order to keep control of the cows. We had no shoes and in the early morning hours in autumn it was already getting mighty cold. That is why we used the opportunity to warm our feet in the puddles of warm urine from the cows; there simply was no other option back then. ${ }^{22}$

Yet, he had even more responsibilities, describing them as follows:

I also had to work for the farmer named Spingies. In the morning, the farmhands put me up on top of the loaded manure wagon, the horse got a tap on its behind and off it went out into the field. The manure was spread there on the land that was going to be planted. Then I was put up on the empty wagon, the horse got a tap and it went back to the farmyard. That is how it went the whole day until evening.

I repeated this work until I was 8 years old, even though I started attending the Lithuanian school when I was 6 . One could say that school was something taken care of on the side, for a couple hours; then I had to once again go back out to the field. ${ }^{23}$

And just how did this activity fit in with going to school? Franz Gauptis tells the story:

As to my being enrolled in school this can be said: There weren't any candy cones or even school clothes, for my parents were poor and only a sown-together bag with a slate and a primer were hung on me. The farmer was the one who decided whether I attended the school classes. The work in the field came first. ${ }^{24}$

\section{Childhood in the City}

In German dominated Memel, the Jews and the Lithuanians oriented themselves on the German way of doing things and to some extent attended German schools. Newly arriving families adapted their outward appearance as quickly as possible. Numerous photos from the time show that the city children in the interwar

21 Ibid.

22 Ibid.

23 Ibid.

24 Ibid., 466. 
period were not distinguished from one another by their clothing or behaviour. We can take as representative recollections of Cherie Goren (born in 1925) and her older sister Fanny (born in 1922) (originally Sarah and Fanny Fleischmann). Cherie recounts:

My sister Fanny and I attended the German school. [...] When I arrived in the Lyceum, we spent a lot of time on the analysis of sentences. We also had a lot of geography in which we learned of what was Germany once upon time. After school I had to go to an apartment where two old, smelly, genteel ladies fallen on hard times helped children of all ages with their homework. I guess German schools were hard. We memorized Goethe and Schiller. We sang songs by Heinrich Heine. [...] A great portion of Jews identified with the Germans and their culture. ${ }^{25}$

At that time it was not common for young girls and boys to be out and about alone in the city except for when they were involved in sports at their clubs. As a rule, in their free time, they were looked after by a nanny (referred to as Fräulein) and also accompanied to and collected from their sporting events. Cherie Goren recounts:

I had a group of little friends. We had a 'kranzchen' (literally a wreath but means here a circle of friends). Freulein served us hot chocolate and pastries in Meissen cups and we worked on our cross-stitch embroideries. Our parents were all friends. We all went to the German schools and spoke German at home. ${ }^{26}$

This all sounds very idyllic and needs a commentary. Cherie and Fanny attended a secondary school, the Auguste Victoria Lyceum, where Jewish girls were a minority. The relationship between German and Jewish girls was quite relaxed because of the attitude of the teachers. The school consultant Kurmis kept a strict watch over the political activities of teachers in the German schools in Memel. Only in 1938 did the situation rapidly change. It can be summarized that the Lithuanian authorities prevented the secondary schools from becoming bastions of nationalism.

In a similar way to the children in the countryside, the children in the city primarily were aware of social differences among the children in their age groups. Among the Germans and the Jews that was likewise the case. There were always subtle boundaries between the Jews who had lived there a long time and those who were new arrivals. This is something that Cherie Goren also underscores:

There were Yiddish speaking girls in the Jewish section but we did not mix with the Ostjuden. My friends and I were embarrassed by their provincial looks, their clothes, and what we considered odd behaviour. How vain and self- important we were. When I was

25 Cherie Goren, A Time To Keep: Grammy Cherie’s Story. (Merion Station, 1999), 12.

26 Ibid., 16. 
out walking with Freulein one day and stopped to talk to a little girl, Freulein insisted that 'those' people were dirty and examined my head for lice. ${ }^{27}$

\section{Free Time and Sports}

Sports were an important element in the national self-image in those years and possessed a tremendous fascination for the older children and the teenagers. Even in the countryside there were sports enthusiasts and a few sports clubs. ${ }^{28}$ In this regard, young people were very similar in the Memel region and in neighbouring Lithuania. However, it must be noted here that there were also political youth associations registered in Lithuania, which carried out sports activities. In the Memel region all kinds of political youth associations were forbidden because of the political tensions. ${ }^{29}$ The Lithuanian Ministry of Education stopped the activities of some politically active youth associations in $1930 .{ }^{30}$

The Jewish youth were involved in organizations just like the Germans and Lithuanians of the same age. Dora Rabinowitz (b. 1919) recalls, 'If the Betar had more enthusiastic and better leaders we went to Betar. If Hashomer was more interesting, and the holiday camp was nicer there we went to Hashomer for summer camp. It had no political significance to us. ${ }^{31}$

Mike Rabinowitz (b.1922) played on the Luise Gymnasium's soccer team. He travelled with the team to Danzig in 1934 and then to Koenigsberg in 1936. At the time the others already were afraid to take him along and never called him by his last name. But they needed him to play for them. Then the atmosphere changed in the school.'I had many good friends, but before we were about to take our final exams in the last year many turned their backs on me. Whether they were ashamed of me or they were afraid of me or they became Nazi through the Hitler Youth... I don't know. One friend remained true to me.32

In 1936, the year of the Olympics, sports suddenly became an even stronger expression of national allegiance. Cherie Goren recalls: 'The 1936 Olympics were very much in the news. I started to notice that the girls in my class were very blond

27 Ibid., 18.

28 Erna Mehner,'Erinnerungen an meine Kindheit in Coadjuthen,' in Uschtrin (Hg.) 2011, [2011 - Wo liegt Coadjuthen, 438-43.

29 Ingrida Jakubavičienè, Lietuvos sporto rèmimo tradicijos XX a. 3-4 dešimtmečiuose. In: Istorija. Lietuvos aukštųjų mokyklų mokslo darbai (89, 2013), 20-30.; BiliūtèAleknavičienè 2004, 141.

30 Biliūtè-Aleknavičienè 2004, 141.

31 Dora Rabinowitz, Yad Vashem Archives, 03/7504.

32 Mike Rabinowitz, Interview with author, November 14, 1999 in Ramat Gan. 
and athletic. There was much marching and singing of German songs about the 'Heimat' or Homeland. ${ }^{33}$

Illustration 8: Inaugural assembly of the Betar in Memel 1927. Betar is a Jewish youth movement founded in 1923 in Riga. The name is short for 'Brit Yosef Trumpeldor'. Trumpeldor was a Jewish fighter who fell at Tel Hai fighting against a superior Arabic force. To the right, above the picture of Trumpeldor, is Dorothee Metlitzki, professor of English at Yale University Society "Jews in East Prussia", Archive.

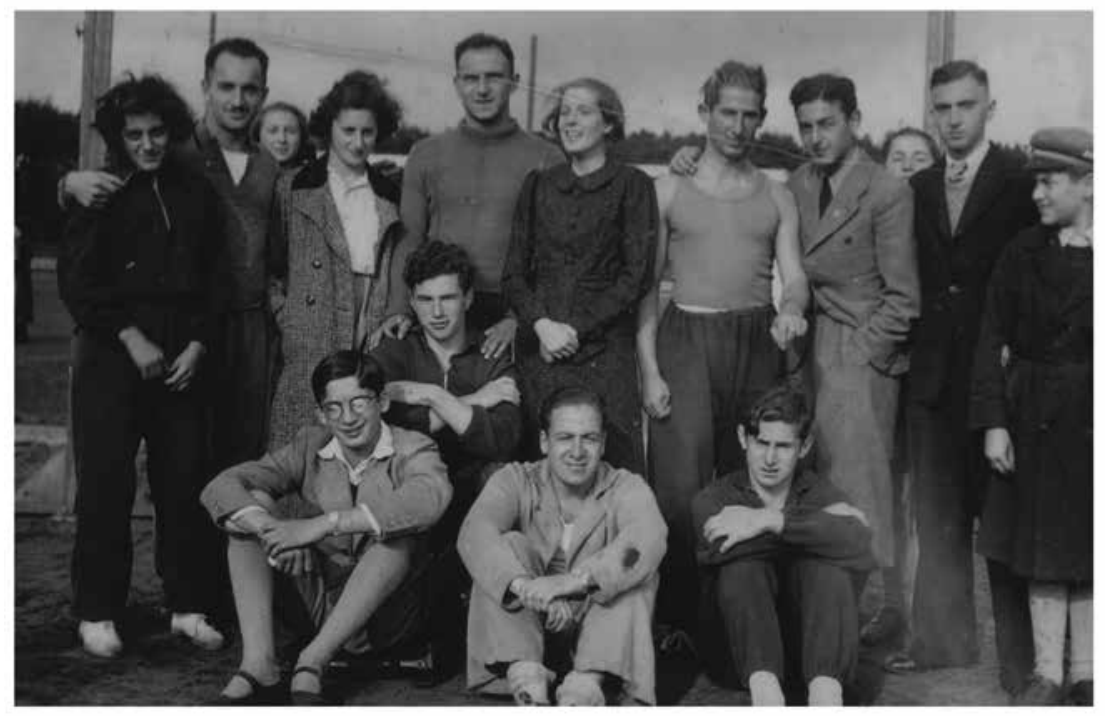

\section{Political Sentiments}

The Schools Inspectorate regularly inspected the teachers, especially the German officials who were to be expelled in 1934. In this context, schoolchildren witnessed unforgettable scenes. Hans Paltins recalls:

Our previous teacher Bajorat could hardly speak Lithuanian. Therefore, he was very often and thoroughly inspected by the Lithuanian Board of Education, which appeared mostly accompanied by another officer. The men appeared without notice. So once they burst in on a geography lesson, and right in front of us children a vociferous debate took place as to why Bajorat let us learn in geography about Germany and not about Lithuania.

33 Ibid., 18. 
The schools inspector took the map of Germany from the card holder, rolled it up and simply took it with him. ${ }^{34}$

Walter Hein, the son of the German school principal in Coadjuthen, experienced his childhood quite attentively. Perhaps that was the result of his father having to concern himself with the political tensions of the time and indeed speaking about them at home. Hein recounts:

1935 was the year when the Neumann-Sass trial in Kaunas had just come to an end. This trial was conducted against Germans from Memelland who had become engaged in the pursuit of German interests -- so, it was a political trial. It resulted in four death sentences and also lengthy prison sentences for 85 Germans. ${ }^{35}$

Some of the convicted persons were even from our village. Presumably that was the reason why a Lithuanian lancer squadron occupied our village for many years. At the time a state of war existed in the Memel Region now separated from the Reich even though self-administration had been guaranteed to the Germans. In 1934 I was ten years old and I can still remember how surprised the Coadjuthens were back then when the occupation of the village began. As young boys, we were playing football that very day when we suddenly heard a loud clatter of horse hooves on the cobblestones on the street coming from Laugallen going in the direction of the town square. We ran down the street after them and could see everything well: a whole lancer squadron on horseback, led by two officers and over 100 soldiers fully outfitted [...]. The officers used Naubur's inn, the soldiers took over the events hall that was part of the Martinus inn. The horses were sheltered in empty barns, with 25 in the stall of Pastor Strasdas. The chuck wagon was set up next to the bicycle shop in the yard of Westfals. For us kids, this was a reason to often stop by as the soldiers with their mess kits got their cabbage soup prepared in a large caldron by two cooks with a lot of cabbage and meat. When you went by there, you always got the strong smell of cabbage soup in your nose. ${ }^{36}$

The political contextualization of this event may be something that perhaps the youngster became aware of at a later point. The young ones who 'often stopped by there' were surely more so attracted by how exotic the events were. And yet,

34 Paltins 1972.

35 The attempted rebellion against Lithuania could not be proved during the trial. Nevertheless, the death sentence was imposed, however not carried out. There were numerous protests against the verdicts. In the end, all those condemned were gradually let go.

36 Walter Hein, 'Coadjuthen unter litauischer Besatzung: Ein Erlebnisbericht von Walter Hein, geb. 1924 in Coadjuthen', in Wo liegt Coadjuthen? Die Geschichte eines ostpreußischen Kirchspiels im ehemaligen Memelland, ed. Günter Uschtrin, 1., new edition, 312-4 (Berlin: Berliner Wissenschafts-Verlag, 2011), 312. 
Walter Hein's description of an election gives a different impression. Here, despite being just 11 years old, he shows himself to be an active observer, as he reports:

1935 was the year of the elections to the Fifth Memelland Parliament. The polling place was in the school and on election day I got myself a spot over the entrance to the school and had a good view of everything from there. With still a half an hour before the opening of the polling place, the Germans and Lithuanians had gathered and the fear was there would be some unrest, which did in fact happen when the Lithuanians were the first ones allowed into the polling place. Then the door was locked, barring the Memellanders. There were loud protests and riots with shouts such as 'Lithuanians get out!' That went on for half an hour, and then I caught sight of the Lithuanian military with arms at the ready and with a lieutenant in the lead coming from the other side of the town square. All of a sudden, the lieutenant paused in place and demanded that the German Memellanders immediately leave the town square. That was clearly an obstruction of the election process. Loud yelling began -- but no one started moving away from the town square. I saw the soldiers fan out and move forward toward the Germans. They struck the Memellanders with their rifle butts. In an instant the town square was empty. The lieutenant ordered the soldiers to return to ranks and then withdraw. That happened and then in half an hour everything was quiet. The election could then proceed without problem. All this, however, really did not help the Lithuanians, because they lost the election by a huge margin: $94 \%$ of the population elected the German candidates. ${ }^{37}$

We can assume that all people of all age groups in the village learned about what had happened. We find in no other recollections from children born between 1920 and 1932 (which have been reviewed for this piece) any references to the political trial mentioned above or to the elections of 1935 (or any other parliamentary elections before 1938). The report from Walter Hein gives a sense of the tensions that reigned in the region and what kind of mistrust of the official administration was present. In this context, an incident described by Cherie Goren appears in a quite different light:

I developed a following of about six boys. My two cousins, Peeps and Bubi were a year older than I. They each wanted to be my boyfriend and had fistfights to see who would walk next to me. There were also Norbert, Izzi, Manfred, and several more, I don't remember their names. [...] These boys were friends of my cousins, so we were all friends. We started a club. Because I had the best ideas, I was elected president. I was also the only girl. We called it the 'Black Hand'. It was a secret organization. We wrote each other letters in invisible ink, played pranks on people, and did harmless mischief. We made stink bombs, and left them in the movie house. One Friday I stole the chicken legs from our Shabat chicken, dipped them into chicken blood, and stamped some writing paper with them. We had a meeting the same afternoon and wrote letters of warning to some

37 Ibid., 313. 
people signed 'The Black Hand' under the imprints of the bloody chicken claws and 'Tutti Fleischmann, president.'We mailed the letters to people at random. We had no stamps, so the post office opened them and called the police. [ ] One afternoon, while Mama was at the fish market again and Papa at the bridge club, two men came to our door and showed Freulein their secret police badges. They wanted to talk to Miss Tutti Fleischmann. A trembling Freulein produced me and sent the rest of the household for my parents. They took me into the living room, closed the door, and began to interrogate me. They must have felt pretty ridiculous at the sight of me, a puny eleven-year-old. If they did, they did not let on. They wanted to know the names of the members of my gang, but I stood my ground - I was not talking. My brother Butzer was hiding on top of the armoire behind the clock, again. Suddenly he piped up, 'I know!' and proceeded to name all of my friends. My terrified parents burst into the room. I think the police dropped the case. Nobody else was picked up. The story spread like wildfire through the town. I was labelled a wild tomboy. The girls were not allowed to play with me, including my cousin, Edith, Peep's sister. We were all severely lectured about drawing the attention of the secret police. I was an outcast for a short while, until I became seriously ill and was redeemed. ${ }^{38}$

This episode clearly shows the high level of political nervousness in the city to the degree that children's letters were investigated.

\section{Jewish Childhood}

In the 1930s, the climate in the school changed. The German children got involved in German groups. While there would not have been the Hitler Youth yet, nevertheless the copycat effect was clearly present. ${ }^{39}$ Jewish children banded together more closely and spent more of their free time together. Trudi Birger (born in 1927), who moved from Frankfurt am Main to Memel in 1933, recounts: 'I cannot remember having experienced any kind of anti-Semitic incidents at school, even though there were only a few of us Jewish students. The teachers treated us fairly. ${ }^{\prime 40}$ Others, primarily the children of immigrant families during the interwar period, remember having sensed anti-Semitism as a child. They were not chosen as playmates and not invited to birthday parties. ${ }^{41}$ In November 1938, the days of Jewish childhood in Memel ended abruptly. Cherie Goren still remembers:

38 Goren, A Time To Keep: Grammy Cherie’s Story., 20.

39 Mike Rabinowitz, Interview with author, November 14, 1999 in Ramat Gan.

40 Trudi. Birger and Jeffrey M. Green, Im Angesicht des Feuers: Wie ich der Hölle des Konzentrationslagers entkam (München: Piper, 1990), 35.

41 Yad Vashem 03/7504 Interview Dora Love geb. Rabinowitz. 
One night, we were told not to go out or near the windows. A German ship was in port and a demonstration was expected. Papa, who had many friends in high places, had been warned. We did not turn the lights on and sat in the dark. We did not have to wait long. We heard loud singing and marching. Hundreds of boots on the cobblestone street and hundreds of voices were singing the 'Horstwessel', a Nazi song, with verses: 'Jewish blood will spill from our sharp knifes' and the German national anthem. As they came to our building they raised their fists and shouted 'Sieg Heil', the Nazi salute. We trembled as we peeked behind the closed drapes. They obviously knew where Jews lived. No police appeared. The band of storm troopers were allowed to roam the city, attack Jews and their properties, without any interference. ${ }^{42}$

Her descriptions correspond with those of other children and teenagers who experienced the ending of the state of war in November 1938. Through that, the national socialist organizations gained the upper hand, whereas prior to that they only existed illegally in the region. In spite of that, Fanny and Sarah Fleischmann were sent off to school the following morning. In cities, it was seen as most unusual to keep the children home.

The next morning Fanny and I went to school as usual. The teacher entered the class with the Nazi salute, 'Heil Hitler!' The class jumped to their feet with arms raised and returned the salute. 'Heil Hitler!' echoed through the school. The Jewish children trembled. Nothing further needed to be said nor was anything ever explained to us. We just knew that we no longer belonged there. On the way home, I was attacked by several classmates. I was beaten and spit on. They called me 'Dirty Jew', but I was not seriously hurt. ${ }^{43}$

The Fleischmann daughters (as were other Jewish children from Memel) were sent to relatives in Riga. Shortly after that, the family emigrated to the United States. The family of Mika and Dora Rabinowitz as well as the family of Trudi Birger fled to Lithuania where shortly after that the events of the war and the persecution caught up with them. Their childhood was irretrievably over.

\section{Conclusion}

The experiences of childhood in the cities and in the countryside during the interwar period were essentially different. By and large it can be argued that childhood in the city of Memel was lived out in a significantly more protected way than in the countryside, although it should be noted that in the villages various models of childhood were manifested concurrently alongside one another. For one thing, the number of children in the urban families was smaller. For another, the children

42 Goren, A Time To Keep: Grammy Cherie's Story, 20.

43 Ibid. 
in the cities had as a rule fewer household chores to do. In addition to this, the children in the city attended school on average longer and without interruption. Over and above that, one can observe an 'at homeness ${ }^{44}$ of urban childhood, which also led to the children being kept at a distance from political events and discussions. They were to dedicate themselves primarily to attending school as well as playtime and sports. One can conclude from this that being in the city afforded a longer childhood. And finally one can conclude that because of the changing political circumstances, for most of the children of the region, their childhood ended abruptly: for the Jewish children 1938; for the Lithuanian children 1939 when the region was separated off and re-incorporated into Germany, and for the German children when in 1944 they had to climb aboard a steamer to flee the area.

44 Jürgen Zinnecker, 'Kindheit und Jugend als pädagogische Moratorien: Zur Zivilisationsgeschichte der jüngeren Generation im 20. Jahrhundert', in Bildungsprozesse und Erziehungsverhältnisse im 20. Jahrhundert, ed. Dietrich Benner and Heinz-Elmar Tenorth, Zeitschrift für Pädagogik, Beiheft 42, 36-68 (Weinheim: Beltz, 2000), 44. 



\title{
Julien Fuchs
}

\section{Youth Movements in Alsace and the Issue of National Identity, 1918-1970}

\begin{abstract}
This chapter studies the youth organizations of Alsace, a region located at the crossroads of Europe, between France and Germany. More specifically, it will concentrate on the period between 1918 (since most of these organizations were born out of the Great War) and the early 1970s (when they entered into a pattern of decline). It will particularly focus on five phases of development of these organizations, periods during which young Alsatians experienced specific forms of involvement: (i) 1918-1932, at a time of re-appropriation of the French lifestyle; (ii) 1932-1939, with the rise of regional separatism; (iii) 1940-1945, with the annexation of the region to Germany; (iv) 1945-1958, with the process of local reconstruction within a thoroughly 'French' environment; and (v) 1958-1970, when young Alsatians were affected by profound social and cultural changes taking place. This study aims to show that ultimately, youth organizations in Alsace contributed to the affirmation of young people, specifically on the dialectic region/nation plan. This was done in a manner that was always relatively specific. However, this regional specificity did not lead to the establishment of particularisms, but rather helped situate a history in which singular patriotic, religious and political stakes were deeply interwoven.
\end{abstract}

\section{Introduction}

In the first half of the twentieth century, many countries throughout Europe witnessed the creation of original groups and organizations dedicated to supporting young people in their physical, mental and spiritual development outside of school hours. Collectively referred to by historians as 'youth movements', these organizations brought together young people who were actively involved in group projects while at the same time learning to be autonomous ${ }^{1}$. These youth movements were

1 We refer here in particular to the following works: Michael Patrick Fogarty, Christian Democracy in Western Europe, 1820-1953 (Notre Dame: University of Notre Dame Press, 1957) ; Richard G. Braungart, 'Historical and generational patterns of youth movements: A global perspective', Comparative Social Research, 7.1 (1984), 3-62 ; John O. Springhall, 'The boy scouts, class and militarism in relation to British Youth Movements 1908-1930', International Review of Social History, 16(02) (1971), 125-158 ; Herbert Moller, 'Youth as a Force in the Modern World', Comparative Studies in Society and History, 10/3 (1968), 237-260 ; Walter Laqueur, Young Germany: a history of the German youth movement (New York: Basic Books, 1962) ; Aline Coutrot, 'Youth 
indeed groups created for and by young people. They differed, for example, in terms of the age of their members, some of them targeting children and teenagers, while others were aimed more at students and young adults. One of the characteristics of these movements was precisely the vague notion of youth that they maintained. However, they all shared a noble goal, namely that these 'young people' should experience teaching methods deliberately removed from normal academic standards, within organizations that represented original venues of expression, action and creativity, where young people could learn to take more responsibility for themselves. In a nutshell, these groups sought to enable young people to assert themselves, and over the past century, many of their members went on to become prominent personalities in the worlds of politics, culture and the economy.

How did such movements become established in the lives of young people? No doubt they were attracted to the principles of commitment these organizations conveyed: commitment to others, to their social background, to religion and to the nation. How then did these organizations attract young people in those European regions with unique social and political situations in the first half of the twentieth century? Was it a question of local specificity at the heart of these movements, on the themes, for example, of the State or the nation? This is the question posed in this paper, which focuses more particularly on one part of Europe with a very specific historical trajectory, namely Alsace, located as it was between 1850 and 1950 'between France and Germany.' This classic and very accurate expression by Alfred Wahl and Jean-Claude Richez refers to a certain hesitation or indecision at the heart of a region historically steeped in the culture of both these nations, and where, unfortunately, European history was often made. Indeed, from 1871 on, Alsace was alternatively annexed by Germany (between 1871 and 1918, and again from 1940 to 1945) and re-annexed by France (during the inter-war period from 1918 to 1940 , and since 1945). It is reasonable to assume that, within this context, the different youth movements in Alsace conveyed a very varied perception of the issue of national identity. ${ }^{3}$

Movements in France in the 1930s', Journal of Contemporary History, 5/1 (1970), 23-35 ; Reuven Kahane, The origins of postmodern youth: Informal youth movements in a comparative perspective, 4 vol. (Berlin/New York : De Gruyter, 1997).

2 Alfred Wahl, Jean-Claude Richez, L’Alsace entre France et Allemagne, 1850-1950 (Paris : Hachette, 1993).

3 This approach represents an unusual and original means of understanding the history of the youth movements in this region. In this sense, it effectively complements the approach of these youth groups from the educational and religious perspectives put forward in the book published on the basis of my PhD (Toujours prêts ! Scoutismes 
In France, historians have taken an interest in the 'youth movement' phenomenon since the 1980s, following the famous study in 1979 by Maurice Crubellier ${ }^{4}$ and based on the pioneering work of authors such as Jeanne Caron on the French political and religious movement Le Sillon or Charles Molette on the Association catholique de la jeunesse française (Catholic Association of French Youth), published in the late 1960s. ${ }^{5}$ Since the 2000s, it is fair to say that youth organizations have 'gone down in history', to quote Gérard Cholvy, ${ }^{6}$ with the publication of numerous works on the subject of a particular group, on federations, on the relationships between socio-educational institutions and the Church or the State, or on the methods, ideologies, or leaders. In France today, there is much literature on these topics ${ }^{7}$. However, it should be noted that the vast majority of these works are monographic studies in that they recount the history of only one type of movement or one association. Moreover, on the rare occasion that this is not the case, the research often appears to be 'situated' historically, i.e., focused on a specific period. We believe that the study of youth movements in such a politicallyand culturally-specific border region as Alsace may allow a wider, more general approach. Indeed, it is our hypothesis that between the end of the First World War (when most movements were created in their modern form, became wellrecognized associations, and clarified their projects and methods) and the 1970s (when they experienced an upheaval in their initial projects and their statute as

et mouvements de jeunesse en Alsace, 1918-1970 (Strasbourg : La Nuée Bleue, 2007)). This text notably attributes importance to some sources that were not exploited in this thesis.

4 Maurice Crubellier, L’enfance et la jeunesse dans la société française, 1800-1950 (Paris : Armand Colin, 1979).

5 Jeanne Caron, Le Sillon et la démocratie chrétienne, 1894-1910 (Paris : Plon, 1967) ; Charles Molette, L'Association catholique de la jeunesse française (1886-1907) : une prise de conscience du laïcat catholique (Paris : Armand Colin, 1968).

6 Gérard Cholvy, 'Les organisations de jeunesse entrent dans l'histoire', Revue d'histoire de l'Eglise de France, 217, 2 (2000), 347-361.

7 Among the best known works, we can notably mention: Arnaud Baubérot, L'invention d'un scoutisme chrétien, les éclaireurs unionistes de 1911 à 1921 (Paris : Les bergers et les mages, 1997) ; Marie-Thérèse Cheroutre, Le Scoutisme au féminin. Les Guides de France, 1923-1998 (Paris : Cerf, 2002) ; Christian Guérin, Lutopie Scouts de France (Paris : Fayard, 1997) ; Alain Michel, Scouts, Juifs et Français. L'histoire des EI de 1923 aux années 1990 (Jérusalem : Elkana, 2003) ; Nicolas Palluau, La fabrique des pédagogues. Encadrer les colonies de vacances, 1919-1939 (Rennes : Presses universitaires de Rennes, 2013). 
legitimate training bodies was called into question), youth movements in Alsace shared many common points, notably in terms of national identity, that allow for considering and studying them together.

At first glance, to undertake the history of all these movements between 1918 and 1970 may appear to be quite a challenge. How indeed can we group together organizations that claimed their own specificity through the diversity of their teaching practices and their ideological positions? Traditional definitions of youth movements can explain this viewpoint. First of all, it should be noted that this study addresses the main youth movements of the time: the different scouts movements, the youth hostels movement, as well as all of the movements falling under 'specialized' religious or secular actions (Young Catholic Workers and Young Catholic Farmers, French Student Christian Federation, Jewish Youth Federation, Student Youth, etc.). These were 'socio-educational' groups, and can be clearly distinguished from 'political youth organizations', which, due to their subordination to a political party, constitute more a part of the history of socialism or communism than the youth movements per $s e .{ }^{8}$ These socio-educational youth movements spread an original perception of non-formal education. They differed from the traditional charities and youth clubs of the late nineteenth century in that they set up a more specific pedagogy and built themselves around the myth of the self-management of young people, following here in a sense the German Deutsche Jugendbewegung of the early twentieth century. ${ }^{9}$ The movements were thus fundamentally built around the triple educational, activist and community paradigm. They therefore shared a common language, even though different inflections and intonations could be heard. ${ }^{10}$ Our purpose here is not to reduce the diversity of youth movements, but to seek to go beyond it, as in the approach taken by Aline Coutrot ${ }^{11}$. Given the vicissitudes of Alsatian political history, it would indeed seem that local movements tended to encourage their convergence, in order to assert their role as actors in the defence of French interests and/or Alsatian characteristics.

8 Joachim Raschke, 'Zum Begriff der sozialen Bewegung', in Roland Roth, Dieter Rucht, eds., Neue soziale Bewegung in der Bundesrepublik Deutschland (Frankfurt: Campus Verlag, 1987), 19-29.

9 Philippe Laneyrie, 'Le mythe du "Jugendbewegung" dans les représentations du "mouvement de jeunesse” en France', Cahiers Jeunesses et Sociétés, 14 (1991), 77-99.

10 Rémi Fabre, 'Les mouvements de jeunesse dans la France de l'entre-deux-guerres', Le mouvement social, 168, 3 (1994), 21.

11 Aline Coutrot, 'Le mouvement de jeunesse, un phénomène au singulier ?', in Gérard Cholvy, ed., Le patronage, ghetto ou vivier (Paris : Nouvelle Cité, 1988), 110. 
This question can be addressed from different points of view. Three key issues are specific to the youth movements of Alsace - interdenominational relationships, relationships between private initiatives and public policy, and the region/nation dialectic - in each of which it is possible to identify a true regional particularity. In an area characterized by the coexistence of three religious communities (Catholic, Protestant and Jewish), the case in very few other regions, youth movements oscillated during the twentieth century between cooperation and competition in the field of religion. ${ }^{12}$ Moreover, the Alsatian movements tended to be rather indifferent with respect to national public youth policies, an attitude they justified by the long tradition of local associations in the region. But it is the third issue which particularly interests us in this paper. How did the perception of the idea of nation and national identity evolve within the Alsatian youth movements? Did they assert themselves as French after 1918, even though they had inherited a share of the local associations that had existed prior to the Great War when Alsace was a Reichsland? To what extent did they affirm their regional uniqueness in order to distance themselves from the French centralizing republican model? How did their positioning with respect to the French nation evolve from 1939-1940 onward?

In our opinion, these questions are fundamental if we are to understand the citizens' agenda that drove the Alsatian youth movements. We will see that in this region, with its undeniable relative proximity with Germany, the 'country of student corporations, ${ }^{13}$ the population cultivated a strong 'regional feeling. ${ }^{14}$ Structured primarily around the idea of cultural boundaries, this feeling was the opposite of the German concept of nationality as defined by Brubaker, i.e., socio-geographical in nature, based on the notion of a people and operating on the principle of national differentiation. ${ }^{15}$ Within this context, the very sensitive theme of nationality permeated the youth movements, the ideological positioning of which relayed strong political rationales that echoed the identity issues of the populations. We will therefore focus on five phases of development of these organizations, during each of which young Alsatians experienced a very specific

12 Julien Fuchs, 'Concurrences et ententes au sein des mouvements de jeunesse. Le cas alsacien (1918-1960)', Vingtième siècle. Revue d'Histoire, 119, 3 (2013), 113-126.

13 Gilbert Gillot, 'Les corporations étudiantes: un archaïsme plein d'avenir (AllemagneAutriche, 1880-1914)', Le Mouvement social, 120, 1982, 45-75.

14 Peter Sahlins, Frontières et identités nationales. La France et l'Espagne dans les Pyrénées depuis le XVII ${ }^{\mathrm{e}}$ siècle (Paris : Belin, 1996), 15.

15 Rogers Brubaker, Citoyenneté et nationalité en France et en Allemagne (Paris : Belin, 1997). 
form of involvement: between 1918 and 1932 at a time of re-appropriation of the French lifestyle; from 1932 to 1939 with the rise of regional separatism; between 1940 and 1945 with the annexation of the region to Germany; from 1945 to 1958 due to the local reconstruction within a thoroughly 'French' climate; and finally between 1958 and 1970, when young Alsatians were affected by profound social and cultural changes. Alsace differed from the rest of France in that it was much more familiar with the world of clubs and associations. Dating back to the middle of the nineteenth century, this way of life was encouraged by the specificity of the region's urban network, its population density and its topographical characteristics. But it also owed much to the fundamental role played by the churches in everyday life, as well as a local cultural background marked by a desire for 'regionalization' and the demand for recognition of a specific identity, through a regional dialect and collective sociability. ${ }^{16}$

This choice of demarcation of the subject is relevant with respect to the sources used for this study, the main corpus of which consists of archives, written and iconographic, public and private, French and German. These include the legal archives of the organizations, the archives of the religious authorities, and the internal archives of the youth movements, the consultation of which is not necessarily easy for the post-1970 period..$^{17}$ It should be further noted that the nature of these archives, many of which come from religious bodies or government departments, confirms our theoretical decision to study what united the youth movements rather than what separated them, insofar as most of these sources provide an overview of all of the movements rather than just one specific organization. This study also draws on the testimonies of key players involved in the youth movements of the time. This approach naturally accompanies the history we have undertaken to portray: the vitality of the Alsatian youth organizations primarily inherited the militant convictions of those who established them, drawing on imaginations and beliefs, and as such can only benefit from an analysis of the discourses.

16 Gabriel Wackermann, 'Associations', in Encyclopédie de l'Alsace (Strasbourg: Publitotal, 1982, 372-373.

17 Julien Fuchs, 'Sources et archives des mouvements de jeunesse. Préalables méthodologiques à une recherche sur l'univers associatif', ¿ Interrogations?, 6, 2008, available at http://www.revue-interrogations.org/Sources-et-archives-des-mouvements, 248. 


\section{The 'relearning' of France by youth movements in Alsace, 1918-1932}

At this time, daily life in the region was organized around the local law in AlsaceMoselle, a legal system operating in parallel with French law, inherited from the German period. The reintegration of Alsace within the French nation in 1918 was thus necessarily problematic. Since 1870 , the population of Alsace had forged a 'mythical' image of France as a democratic country. It firmly believed that France would respect its language, culture and religious specificities, and grant the region the power and even the specificity that Germany had always denied it. It believed that the terms of the Concordat of 1801, an agreement that recognized religious freedom and privileged relationships between the Church and the State, would be maintained. As Paul Smith puts it, it was thought at this time that this 'small country' would be able to 'negotiate with the assimilative thrust of the nationstate. ${ }^{18}$ However, the refusal of France to recognize Alsace as a national minority was manifest. It fed the development of what historians modestly call the Alsatian malaise. ${ }^{19}$ To what extent was it possible to aspire to the respect of regional characteristics while belonging to a republican country? This paradox was strongly felt within the youth organizations of the time. Their development must thus be understood in a dialectic of uniformity and individuality, between promoting patriotism and defending local specificities.

The first half of the nineteenth century saw the development of a craze for socio-recreational activities in Alsace (evening gatherings, games, theatre, etc.), reflecting a real 'spirit of association [...] meeting all the needs of the social and intellectual life: charities and other organizations promoting instruction and the raising of moral standards, ${ }^{20}$ giving rise to a very dense breeding ground for associations throughout the towns and villages of Alsace. This vitality, already identified by Maurice Agulhon and Maryvonne Bodiguel in their work on the history of sociability in rural areas, was all the more evident in this region, as in Provence and in Flanders, than in other French provinces, the border regions appearing to

18 Paul Smith, 'À la recherche d'une identité nationale en Alsace (1870-1918)', Vingtième siècle. Revue d'histoire, 49 (1996), 24.

19 Geneviève Baas, Le malaise alsacien, 1919-1924 (Strasbourg : Développement et Communauté, 1972).

20 Charles-Frédéric Faudel, 'La Société Alsato-Vosgienne et le Schwarzwaldverein', Bulletin de la Société d'histoire naturelle de Colmar (1868), 1. 
be more conducive for its development. ${ }^{21}$ The newly-formed associative network structured itself around the Wirtschaft, genuine melting pots of social solidarity, where all of the associations held their meetings. The annexation of Alsace to Germany in 1870 did nothing to stifle this vitality, contributing instead to accentuate its uniqueness. Indeed, this integration of Alsace within the Reich and the subsequent Germanization policies further strengthened the bonds of solidarity and community spirit. Within this context, the Alsatian associations of the period (including brass bands, study circles, choirs, hiking and gymnastics clubs, etc.) became groups and organizations involved in the consolidation of a regional identity, most of them claiming a real distance with the German authorities. In the field of youth work, this process took the form of the creation of numerous youth circles and organizations for children, usually established by local parishes and often referred to as 'youth clubs. ${ }^{22}$

These youth clubs sought to attract young people through fun activities, theatre, gymnastics and the first sports activities, immersing them within a framework of morality and belief. They were especially involved in spreading a strong local feeling, fuelled in particular by the question of the preservation of religious differences. One notable example is that of the Avant-garde du Rhin, originally founded under the name Elsässischer Turnerbund (ETB), a major Catholic sports association (with nearly 12,000 members in 1914) that united many youth wings. Created in July, 1898 in Ingersheim by a layman, the aim of the ETB was to bring together Catholic youth to encourage their development through physical activity. But the association also immediately took a very political stance with a resolutely pro-France attitude. Founded only one month after the Fédération gymnastique et sportive des patronages de France (FGSPF, a gymnastics and sports federation of French youth clubs), and although it originated while Alsace was a Reichsland, the ETB claimed a regional league status as part of the FGSPF, i.e., as an association with French ties. At the same time, its leaders refused to be affiliated with Deutsche

21 Maurice Agulhon, Maryvonne Bodiguel, Les associations au village (Le Paradou : Actes Sud, 1981), 14.

22 Just before the First World War, Alsace numbered 95 youth groups affiliated to the Fédération des cercles catholiques d'hommes et de jeunes gens d'Alsace (Federation of Catholic men's and youth groups in Alsace), 48 Protestant young men's groups and 33 young women's groups, as well as around 10 Jewish groups (Archives of the Bishopric of Strasbourg, ORDO, 1914; Archives of the Board of the Augsburg Confession of Alsace-Lorraine Lutheran church, directory of the Protestant churches of Alsace and Lorraine, 1919). 
Turnverein, the German Gymnastics Federation, earning the ETB a few run-ins with the local authorities.

The Alsatian scout movement, coming only a few years after the German Pfadfinder movement created in 1909 and structured around the Christlicher Verein Junger Männer (CVJM), the German counterpart of the Young Men's Christian Association (YMCA), was also France-oriented right from the outset. It was founded just before 1914 in the French-speaking sections of the Protestant Reformed and Lutheran unions of the Elsass-Lothringischer Evangelischer Jünglings-Mädchenbund, local versions of the CVJM, and which comprised at the time both French- and German-speaking sections. It is likely that during the Great War these groups were involved in covert activities against the German authorities (sabotaging of telephone lines, publishing of underground newspapers), as attested in certain archives of the Éclaireurs unionistes de France (Unionist Scouts of France). ${ }^{23}$ In all cases, the representation of an Alsatian scout movement was built around these first initiatives, and in accordance with its motto, 'In all things, serve God and country', served the motherland lost in 1871. As such, it can be compared with the patriotism at the origin of the Boy Scout movement, founded in 1907 by Robert Baden-Powell.

From 1918-1919 onward, the scout movement in Alsace grew in a very homogeneous way around the Protestant parishes, whereas it was generally more heterogeneous in the rest of France. The originality of the scouting life attracted young people from all denominations within this Unionist (Protestant) and fundamentally cosmopolitan movement. In Strasbourg, Guebwiller and Colmar, teenagers from lay and Catholic communities joined the Unionist units, as no Catholic structure or local version of the Éclaireurs de France (non-religious scout movement) had as yet been created in Alsace. Indeed, in the immediate post-war period, there was broad consensus on the idea of developing activities around the already structured Unionist movement. This coexistence of Protestant, Catholic, Jewish and secular scouts within the same units posed no problem for either the young people or the officials, primarily excited by the spread of the Scout ideal: 'In 1920, Protestant scouts [...] invited me to join them [...] and explained what this experience would involve and how they would help me start up a Scouts de France troop', said Jean Burklé, founder of the first Catholic Scouts de France troop in Guebwiller in $1922 .{ }^{24}$ In Mulhouse and Strasbourg, the first Jewish scouting

23 Archives of the Éclaireurs unionistes de France (Paris). Jean Beigbeder Collection, card B1.

24 Cité par Charles Keller, Christian Stoecklé, Scouts de France Guebwiller, 1922-1987 (Guebwiller : Art'Real, 1987), 3. 
initiatives were also located within the Unionist sections. Gradually, the Alsatian scout movement diversified and strong interfaith conflicts arose. The Catholic scout movement, for example, was founded in 1920 at the express request of the Bishop of Strasbourg, in order to counteract the influence of the Protestant and secular scout movements, while the secular scouts faced competition from the Protestant scouts to become recognized with the authorities. However, in terms of their relationship to the nation, it was the idea of an Alsatian scouting movement united around a pro-French base that was built, including in the Protestant parishes of northern Alsace, often considered more pro-German than the rest.

The success of scouting in Alsace constituted the first sign of a deeper trend: the development of a diversity of youth movements. In the same way that they spread at national level, the youth movements in Alsace experienced remarkable growth locally from 1920 on. With the return of Alsace to France, these movements spread thanks to the dense breeding ground of associations that had existed in the region's towns and villages since the mid-nineteenth century. Different branches of scouting were founded and made a lasting impression. These included the Scouts de France (Catholic Scouts) in November 1920, the interdenominational Fédération française des éclaireuses (French Girl Guides Federation) in January 1922, the secular Éclaireurs de France scouts in October 1922, and the Éclaireurs israélites de France (Jewish Scouts) in October 1929. They inspired other activities such as summer camps and countless parish and youth groups where physical exercise and nature outings were organized in addition to Bible studies. The principle of these groups was unique: they allowed young people to experience life in a community and to gain autonomy, thereby revealing their desire to differentiate themselves. ${ }^{25}$ For Alice Gillig, team leader in the Catholic Girl Guides, the scout movement represented a 'real breakthrough' for young girls, a 'means of going out and seeing the world'. ${ }^{26}$ But they also encouraged commitment of a more political nature, and in Alsace this politicization led to a reconciliation of the organizations when they felt their specificity was threatened. Thus, while the movements were united in proclaiming their ties with France, its people and its culture, they also simultaneously lined up to defend the regional character of Alsace.

This was particularly the case in 1924, when the government of Édouard Herriot began to repeal local civil legislation to absorb Alsace within the French Republic. In line with the bishopric, and like the majority of Alsatian members

25 Antoine Prost, 'Jeunesse et société dans la France de l'entre-deux-guerres', Vingtième Siècle. Revue d'histoire, 13, 1 (1987), 42.

26 Interview with Alice Gillig (April 16 $\left.{ }^{\text {th }}, 2002\right)$. 
of parliament and senators, the steering committee of the Fédération des cercles catholiques d'hommes et de jeunes gens d'Alsace (Federation of Catholic men's and youth groups in Alsace) denounced the heavy-handed francization policy. This Federation was widely supported by the Association catholique de la jeunesse française (Catholic Association of French Youth), whose intention was to unite the young Catholic troops in the defence of the interests of the Church, which felt threatened 'in these times of triumphant anticlericalism. ${ }^{27}$ Comprising influential members of the Action populaire nationale d'Alsace, a Liberal Catholic party, the aim of this steering committee was to bring together the different youth organizations to 'protest in the strongest terms' against this attack on the 'most sacred rights. ${ }^{28}$ The struggle, relayed for example in the Les jeunes d'Alsace, a newspaper with a French title but published in the Alsatian dialect, mobilized groups well beyond the Catholic sphere (see Fig. 11) Indeed, although largely inclined to spread French culture, ${ }^{29}$ the Young Men's Christian Associations in Alsace-Lorraine, and notably the Unionist Scouts, brandished the local culture through songs and sketches in Alsatian. The use of the local dialect thus took on an identity meaning. ${ }^{30}$

From 1918 on, these very diverse movements came together around the idea of the reintegration of Alsace within France, but based on the respect of local specificities. Initially caught up in the euphoria that followed the end of the First World War, they started to become more careful about joining the French model towards the mid-1920s. This nevertheless remained an obvious choice, particularly in 1925 and 1926, at the time of the first separatist upsurge of the inter-war period. Indeed, following the withdrawal of the Herriot legislation, regionalist tendencies started to emerge, dividing public opinion on the status of Alsace within France. The publication in May 1925 of Zukunft, a newspaper that demanded independence from France in the name of the 'Alsatian people', followed by the Heimatbund in June 1926, a manifesto inciting all Alsatians faithful to their 'country' to unite in order to achieve full independence, crystallized tensions in the region. Despite the fact that the youth movements generally refrained from taking partisan positions, the Catholic movements, in line with the Bishop of Strasbourg, as well as the vast majority of the Protestant and Jewish movements declared themselves strong opponents of regional independence, potentially radical and anti-French. Their

27 Alain-René Michel, Catholiques en démocratie (Paris : Cerf, 2006), 52.

28 Archives of the Avant-garde du Rhin (Strasbourg). Les jeunes d'Alsace, 23 June 1924.

29 Catherine Storne-Sengel, Les protestants d'Alsace-Lorraine de 1919 à 1939 : entre les deux règnes (Strasbourg: Société savante d'Alsace, 2003).

30 Anne-Marie Thiesse, La création des identités nationales : Europe, XVIII ${ }^{\mathrm{e}}-\mathrm{XX}{ }^{\mathrm{e}}$ siècles (Paris : Seuil, 1999). 
activities thus took on a very patriotic aspect, as clearly evidenced by the organization of pilgrimages to the emblematic battlefields of the First World War (Verdun and Hartmannswillerkopf, also known as the Vieil Armand), or the sponsorship of Alsatian units by such leading figures of the time as General Lyautey, honorary president of the Catholic Scouts, Captain Guynemer, who gave his name to a Unionist Scouts troop in Mulhouse, and General Gouraud, liberator of Strasbourg and a guest at the provincial camp of the Unionist Scouts in Obernai in 1928.

\section{Youth movements and the regional issue, 1932-1939}

By the early 1930s, Alsace boasted a varied landscape of youth organizations. The movements had become even more rooted in the lives of the young population. The different scout movements (Catholic, Unionist, Jewish and, to a lesser extent, secular) boosted the local fabric of associations by intensifying outdoor activities. The parish circles asserted their position as guarantors of the local culture. But groups of a new kind also started to appear. Youth hostel federations, for which the Vosges represented an ideal venue for their activities, immediately attracted a lot of young men and women who thus discovered a unique lifestyle and a specific mindset: one of strong antimilitarism and a hope in pacifism, an ideal cultivated in French schools as a form of opposition to the Republican moral doctrine of the late nineteenth century, which had led the previous generation to accept the war of 1914-1918 without question. ${ }^{31}$ Germany and France could be friends since their young people fraternized in youth hostels. The youth hostel movement largely contributed here to the dissemination of a political ideal, especially given that it was widely supported, from 1936, by the Socialist government of the Popular Front, a coalition of French left-wing parties. Before the rise of authoritarianism in Europe, this ideal, which transcended religious and Republican divides, found its fullest expression. Among the first French youth hostels created in the early 1930s, the Alsatian hostels, inspired by the German Jugendherberge designed by Richard Schirrmann, became preferred vehicles for disseminating an 'urban hiker habitus. ${ }^{32}$ By the mid-1930s, there were some fifteen youth hostels in Alsace. What is known as 'specialized' Catholic Action (i.e., specific to a particular social environment) was also born during this period. This included the Jeunesse ouvrière catholique (Young Catholic Workers) and the Jeunesse agricole catholique (Young Catholic Farmers), created in the 1931-1932 period in the region (1927 and 1929,

31 Mona L. Siegel, The moral disarmament of France: education, pacifism, and patriotism, 1914-1940 (Cambridge: Cambridge University Press, 2004).

32 Wahl, Richez, 273. 
respectively, in France), and the Jeunesse étudiante catholique (Young Catholic Students) in 1935. These associations, which offered a sociologically differentiated management of young people and encouraged activism, met with great success because they came in answer to a social need. In 1938, these three movements together had no fewer than 99 male sections and 96 female sections in the region.

During the 1930s, the work of youth associations in Alsace was thus multifaceted and effective. All of these movements had their roots in traditional parish circles, from which they progressively emancipated themselves. Initially very local structures, they gradually became regional-scale organizations but whose actions were situated within a broader context. The Alsace Province of the Catholic Scouts, for example, took on the ideological and pedagogical guidelines dictated by the national Scouts federation. The Young Catholic Workers association in Alsace was also fully in line with the policies and actions undertaken by the Parisian structure, for example by following the same campaigns (annual themes of reflection and action) as those launched at the national level.

In this sense, as they developed, the youth movements in Alsace also lost their initial specificity, and even claimed to be local workings of a much broader trend. Thus, little by little, groups of young Alsatians also integrated the beginnings of a public policy dedicated to youth, as it would later be implemented, notably from 1936 on with the Popular Front. In any case, by the end of the inter-war period, the youth movements had grown on a considerable scale, affecting all walks of life. It is difficult to assess the numbers of young people concerned by these movements. According to Antoine Prost, nearly $10 \%$ of young people were members of a youth movement in France at this time. ${ }^{33}$ In Alsace, where the network of associations that had existed since the late nineteenth century was more developed than in the rest of the country, this figure was even higher: given the total membership of the Alsatian movements, we can estimate that one out of every eight young people was concerned.

While the coherence of the youth movements in Alsace in the 1930s was palpable in terms of the pedagogies implemented and their educational purposes, it was especially greatly enhanced by their consensus when confronted with the separatist threat. Since the mid-1920s, the Alsatian separatist movement had been divided between two tendencies, the one rather regionalist and the other openly pro-German. ${ }^{34}$ Indeed, faced with the domestic French political crisis and the

33 Antoine Prost, Histoire générale de l'enseignement et de l'éducation en France, T. IV, L'école et la famille dans une société en mutation, 1930-1982 (Paris: Labat, 1982), 497.

34 Christian Baechler, 'L'autonomisme alsacien dans l'entre-deux-guerres', Revue de l'Association des Professeurs d'Histoire et de Géographie, 347 (1995), 249-255. 
external threat from Germany, the moderate majority of separatists worked on reconciliation with the national parties. But at the same time, other leaders greatly strengthened their positions, even going so far as to proclaim their admiration for the Third Reich. While pro-German regionalist ideas became less and less popular within the separatist parties, they were nevertheless virulent, especially where the youth movements were concerned. Within this context, while the regional sections of the French far-right leagues such as Jeunesses patriotes (Patriotic Youth), Action française (French Action) and Croix-de-feu (Cross of Fire), supported by the German authorities, grew in numbers and encouraged the creation of anti-Semitic committees, the separatist youth movements born in the mid-1920s became more radical.

In 1931, the Jungvolkspartei (Young People’s Party) was created by Joseph Rossé for 18- to 28-year-olds. It counted among its ranks Georges Spitz, head of the Jungkreuzfahrer (Young Crusaders) and secretary of the student association Alsatia. But two other prominent Alsatian separatist youth movements are particularly worthy of note. Very active on the political landscape up until the war, the Jungmannschaft and Bund Erwin von Steinbach, whose memberships increased significantly, were led by two of the most active members of the Alsatian pro-German separatist movement, Hermann Bickler and Friedrich Spieser. The Jungmannschaft advocated a community and racist conception of society in which social classes would disappear and where a sense of Volkstum would emerge. The association operated in the same way as the Hitler Youth. Its insignia, the red Wolfsangelrune on a black background, was none other than the mantrap of the peasant uprisings. In the same vein, the Bund Erwin von Steinbach extolled traditions and village life as trustees of ethnic purity, as well as the Alsatian culture and language, purely and simply Germanic. The rock outcrop at Hunebourg, acquired by the organization, was the venue for numerous rituals involving young people converted to Nazism.

The socio-educational organizations in Alsace, which promoted themselves as places of training and responsibility, were forced to take a stand here in the early 1930s. Overwhelmed by the German situation and the echo of pro-German stances relayed throughout the region by the press and Radio Stuttgart, their leaders reacted to the radicalization of the separatist movement. They included many influential intellectuals who taught at the University of Strasbourg, notably historians Marc Bloch and Lucien Febvre, philosophers Georges Canguilhem and Jean Cavaillès, and sociologist Maurice Halbwachs. The Jewish youth movements were, of course, in the front line. Grouped together in Strasbourg within the Mercaz Hanoar, a kind of community centre for Jewish youth, their members led courageous actions in defence of the status and rights of the Jews when confronted with radical separatist 
leaders. Conferences, activities and evening events were organized during which attempts were made to develop an effective scout movement where Jewish children and teenagers would find a more appropriate place in Alsatian society.

From 1932 on, the French Student Christian Federation denounced the danger of a germanization of the movements. The Unionist Scouts of Alsace, led at national level since 1936 by the Rev. John Gastambide, a follower of Karl Barth, also refused the regionalist theme. In 1938, they wrote the Chanson d'Alsace anthem. As if those who were to sing this anthem considered themselves under threat, the score indicated that it should be sung to a 'martial' beat :

Joyeux enfants de la vaillante Alsace / Merry youth of valiant Alsace

Partons gaiement pour les rudes combats. / Cheerfully we face battle.

Car nul de nous ne trahira la trace, / For not one of us shall betray the path,

Qui sous l'effort jamais ne succomba. / And none shall ever fall.

Que nos voix s'accordent bien! / May our voices rise in unison!

Que le cri porte au lointain, / May our cry be heard afar,

La rumeur de notre entrain. / The sound of our spirit and passion.

$[\ldots]$

Oui, nous t'aimons, ô notre chère Alsace. / Yes, we do love you, our dear Alsace.

En vain le temps peut égrener son cours, / In vain does time mark off its course,

Dans notre cœur rien ne prendra la place, / For in our hearts nothing shall replace

Que nous gardons à ton fidèle amour. / Your constant love for us.

Que nos bras soient toujours forts, / May our arms always be strong,

Pour lutter jusqu'à la mort, / To fight to the death,

Prêts à défendre ton sort. / Ready to defend your fate.

[...]

Nous chantons pleins d'assurance, / And we sing out with confidence

Dans la joie ou la souffrance : / Whether in joy or sorrow:

Alsace et France! / Alsace and France! $!^{35}$

This Protestant vitality resulted, in 1938, in the establishment of an inter-movement Committee with a view to consolidating the efforts of these associations against Nazism. This Committee would later become the Cimade, an ecumenical association providing assistance and support to people uprooted by war and which is still very active in France today. The Alsatian youth hostel movement also witnessed numerous pacifist and anti-German stances. Finally, communism being a prime target of regionalist extremism, movements such as the Young Christian Workers took clearly anti-separatist positions, stating, for example, in 1938 that they were making every effort to convey a democratic ideal in Alsace.

35 Alain Morley Collection, 'Tisons' EEUF National Conservatory, Schillersdorf (Bas-Rhin). 
While the stands taken against separatism and Nazism abounded in the Alsatian youth movements of the 1930s, their activities obviously involved much more than that. Behind the official discourse, these groups especially worked to pursue ordinary activities (multiplying weekends, camps and training sessions until the summer of 1939), without making the fight against extremism a priority in their daily lives. This does not mean that the Alsatian youth groups were not interested in the political cause. On the contrary, through their wish to not necessarily involve their young members in the debate, they actually took a very real stand. By defending above all other concerns an educational ideal and the notion of peace, they attempted to preserve a place of moral education for Alsatian youth.

\section{A new 'union sacrée', 1940-1945}

The outbreak of the Second World War obviously rendered even more palpable the ideological rapprochement between the youth movements in Alsace. In September 1939, the evacuation of 370,000 Alsatians to the 'France of the interior' was ordered following the declaration of war. In June 1940, the region was automatically annexed to Germany. Between these two points in time, the vast majority of the youth movements disappeared. Those that remained became 'active minorities ${ }^{36}$ who tried to organize themselves in the face of Nazi brutality. From here on in they followed two different trajectories: one in Alsace where the Nazi yoke choked the majority of them, and the other in the départements of their exile. For each of these groups, the goal was not to lose contact with the regional structures (when they continued to exist) or with those at national level, let alone with the leaders and members that had been dispersed. From that point on, the Alsatian movements put their differences behind them and presented a united front.

In Alsace, the few units that did not stop their activities in September 1939 took part in the support process that accompanied the evacuation. Scout troops from Colmar met to carry out liaison duties, population census and the distribution of gas masks. ${ }^{37}$ Elsewhere in Alsace, members of the Young Catholic Workers and Farmers associations, the Catholic and interdenominational Girl Guides offered their services in hospitals and railway stations. Although deprived of their elders, called up for war, these groups developed a new sense of commitment that was responsive, collective and showed solidarity. Nevertheless, the actions of the youth

36 Olivier Wieviorka, 'À la recherche de l'engagement (1940-1944)', Vingtième Siècle. Revue d'histoire, 60, 4 (1998), 59.

37 Departmental archives of the Haut-Rhin (Colmar). 8.AL.2.- Purg. 13107 : Shippings of masks to the populations. 
movements in Alsace remained very limited, hampered by Nazi policies. By the Order of 16 August 1940, the youth associations were dissolved. From that point on, any activity on their part could only be underground. Despite the injunction, some groups continued to meet secretly, within the framework of Bibelstunden (Bible studies) for teams of the Young Christian Workers, ${ }^{38}$ or during meetings in all but name for the Temple-Neuf troop of the interdenominational Girl Guides, the Guynemer Unionist Scouts troop of Mulhouse, or the Foch clan of the Catholic Scouts in Guebwiller. Some notable Resistance initiatives were witnessed between 1940 and 1942, such as the Pur-sang network courageously run by the Catholic Girl Guides in Strasbourg. In accordance with the principle 'The Girl Guide is the daughter of France and loves her country', six young Alsatian women set up an escape network from Alsace to France, which was used by more than four hundred prisoners and opponents of annexation until it was dismantled in March $1942 .{ }^{39}$ But aside from these isolated initiatives, the vast majority of the movements had no other choice but to shut down.

It was thus in places of exile that the history of the youth movements in Alsace during the war was written. In the Dordogne, where the inhabitants of Strasbourg and other Alsatian administrations found refuge at the time of the evacuation, certain units reformed in September 1939. These included teams of Young Female Workers who, following a call from the bishopric to revive Catholic Action in the host departments, participated in the Office catholique des réfugiés d'Alsace (Catholic Office for refugees from Alsace) in Périgueux. The central committees of the Unionist Scouts and Christian Unions sought to encourage the resumption of activities by specifically Alsatian units as soon as conditions were favourable. Finally, with regard to the Jewish movements, initiatives to maintain contacts between the evacuated youth groups also increased. At Brive-la-Gaillarde, Périgueux and Toulouse, local scout troops were reformed.

Responding in their own way to the temptation of 'one youth' outlined by the new French authorities, ${ }^{40}$ the primary objective of these groups in exile was to cultivate an ethic of solidarity between Alsatians. Within this context, relationships were primarily formed through circulars and newsletters bearing iconic names. The Quand même newsletter of the Alsatian Catholic Scouts contained news of

38 Michel Deneken, L'Eglise d'Alsace, 1940-1945. Une Eglise locale face au nazisme (Strasbourg : ERCAL-Publications, 1989).

39 Julien Fuchs, 'Le réseau des Pur-Sang. Des Guides de France dans la Résistance en Alsace', in Arnaud Baubérot, Nathalie Duval, ed., Le scoutisme entre guerre et paix au XXe siècle (Paris, L'Harmattan, 2006), 167-191.

40 Wilfred Halls, The Youth of Vichy France (Oxford : Clarendon Press, 1981). 
the region, indications of activities to be developed, and calls for reunification. The Unionist Scouts' Lettre d'Alsace newsletter was sent to the main places of refuge of its Alsatian leaders in order to maintain a living link. The publication of other newspapers on a smaller scale contributed to uniting Alsatian youth movements in unoccupied areas, the structure of which was symbolically maintained.

In everyday life, these groups persisted through the organization of common actions. These included the camps at Combovin in 1941 and Vieille-Brioude in 1942 for the Unionist Scouts, during which Alsatian scouts from all over France revived the Alsatian atmosphere, the camp at Aiguebelle for the Alsatian Catholic Scouts and Girl Guides, and the camp at Saint-Léonard-de-Noblat for the Alsace province of the interdenominational French Girl Guides Federation in $1942 .{ }^{41}$ These movements especially agreed on the issue of rescuing Jews. The Alsatian Unionist organizations, in accordance with their motto 'Enlarge the place of thy tent', allowed the Jewish Scouts to use their badges, uniforms and membership cards. This was the case in July 1942 and July 1943 at the camps at Saurier and Vernet-la-Varenne, led by Thérèse Klipffel, who was appointed Commissioner for the Alsace province of the interdenominational French Girl Guides Federation after 1945. Klipffel went on to take up responsibility at national level for the movement, before becoming a pastor and being elected President of the Reformed Church of Alsace-Lorraine in $1982 . .^{42}$

Between the Alsatian movements, the apparent cooperation, also noticeable at the national level but in a more contrasted way, ${ }^{43}$ continued to grow as the end of the war approached. From the summer of 1942 on, leaders from all movements met in the clandestine groups of the 'Ballons' in Paris and the 'Hansi' in Lyon. Some important gatherings intensified this profound union. The Puy pilgrimage of 15 August 1942, notably, took on particular significance for the Alsatian movements. It constituted the beginning of effective cooperation between Alsatian Catholic, Protestant and secular leaders in the struggle for the return of Alsace to France.

41 Archives of the French federation of the Scouts (National and University Library of Strasbourg). SR2.7. East Region, Collection Elisabeth Klaenschi and Marie-Louise LéviHamburger.

42 Thérèse Klipffel, 'Les archives de la Fédération française des éclaireuses', Bulletin de la Société de l'histoire du protestantisme français, juillet-août-septembre (1997), 545-551.

43 The creation of the Fédération du Scoutisme Français (Federation of French Scouting) in the summer of 1940 allowed for overcoming the antagonisms of the scout movements. In fact, it did not preclude a divergence of their position with respect to the regime (Bernard Comte, 'Les organisations de jeunesse', in Jean-Pierre Azéma, François Bédarida, eds., Vichy et les Français (Paris: Fayard, 1992), 412). 
It built up around the figure of Bernard Metz an Alsatian resistance network that drew on movements of all persuasions. A similar intention was evident at the camp at Bouchet lake, held in the summer of 1943 by the Unionist Scouts of Alsace. All provincial officials of the Alsace scout movements met here to discuss the reorganization of the Liberation movements. Finally, the 'Carrefour des Tilleuls', which brought together in Clermont-Ferrand Catholic teachers, the Catholic Scouts, Unionist Scouts and Young Christian Students, prepared an action plan for the cultural reintegration of Alsatian youth. At the heart of these initiatives, the commitment on the part of the young people lay in the primary rejection of the occupying forces and the incidental rejection of Vichy France, whose related policies involved treating youth as outcasts. ${ }^{44}$ It was coupled with a united struggle for the denazification of Alsace. In this dramatic context of war, the Alsatian youth movements catalyzed the desires of young people determined to commit to France and Alsace. In other words, they emerged as effective political - or rather civic - action supports.

\section{The 'refrancization' of youth through popular education, 1945-1958}

Between late autumn 1944 and early spring 1945, Alsace gradually freed itself from the German annexation. The post-war period was a time of transition and uncertainty, during which a past to be assimilated and a future to be built coexisted. Within this context, the reconstruction of the youth associations, although difficult and painful, was marked with the seal of hope. Various initiatives were identified, either private or public, which sought to boost the restarting of these associations. At the heart of most of the Alsatian movements, a new common goal, once again looking beyond the strife, took on an essential role, namely that of contributing to the return of Alsace to the French nation or, in other terms and to use the words of the actors of the time, the 'refrancization' of Alsace as they were used to say, the 'rebirth' of this region within the French nation.

The ambition was to transform the youth movements into 'schools of the nation', privileged places of learning ways of thinking and values perceived as specifically French. Asserting themselves as links in the chain of integration within the French Republic, the movements thus worked to maintain their communion. Their involvement in the association Jeune Alsace, created on 20 January 1945 in order to coordinate their reconstruction with a view to the cultural reintegration

44 Olivier Wieviorka, 'La résistance, une affaire de jeunes ?', in Jean-William Dereymez, ed., Être jeune en France (1939-1945) (Paris : L'Harmattan, 2001), 252-253. 
of youth within the national context', to quote the official statutes, was significant. ${ }^{45}$ The Catholic Scouts, Unionist Scouts, Catholic Girl Guides, representatives of the French Girl Guides Federation, as well as delegates from the Communist Youth, the Young Christian Workers, the Catholic sports movement and the Christian Unions gathered here at the end of autumn 1944. Jeune Alsace was a cooperative structure. Its intention was to act as an independent Alsatian office of youth and popular education. The initiative was supported by the local prefectures, which saw it as a way to relay the national policies in the Bas-Rhin and Haut-Rhin departments. With the help of the photographic service of the army, Jeune Alsace started publishing a bimonthly newsletter in February 1945 and produced a 'Quart d'heure de la jeunesse alsacienne' fifteen-minute slot on Radio Strasbourg which gained a large audience. It was the very principle of the association that appealed to so many: the union it symbolized demonstrating the will to be part of the cultural and socio-educational policies established at the national level, while at the same time adapting them to the local context. ${ }^{46}$

Along the lines of Jeune Alsace, the majority of the Alsatian movements indeed wished to participate in the establishment of a real public service for popular education and youth, as was being structured at national level at that time. ${ }^{47}$ This involved readjustment on the part of the local youth. While the difficulties involved in moving away from the Alsatian culture were undeniable, especially among farmers and workers movements, the desire to get away from particularism was evident. The lay movements especially wanted to be vectors of this readjustment. It was one of their scouts who designed a famous poster that read 'It's chic to speak French' and that was displayed in the streets, trams and administrations of Alsace during 1945 (see Fig. 12). ${ }^{48}$

45 Archives of the District court of Strasbourg. Statutes of Jeune Alsace (February 7th, 1945).

46 Julien Fuchs, 'Jeune Alsace, école de la nation (1944-1947)', Agora Débats/Jeunesse, 40 (2006), 22-36.

47 Françoise Tétard, 'Les avatars d'une administration. L'organisation du "Service public d'éducation populaire"', Cahiers de l'animation, 57-58 (1986), 321-324.

48 Departmental archives of the Haut-Rhin (Colmar).756.W.OD, 24.OD.378. Laic scouts of France (1946-1965). 
Illustration 9: Cover of the first issue of the magazine Jeune Alsace. The image of loyalty and gratitude (Jeune Alsace, $n^{\circ} 1$, February 1945). ${ }^{49}$

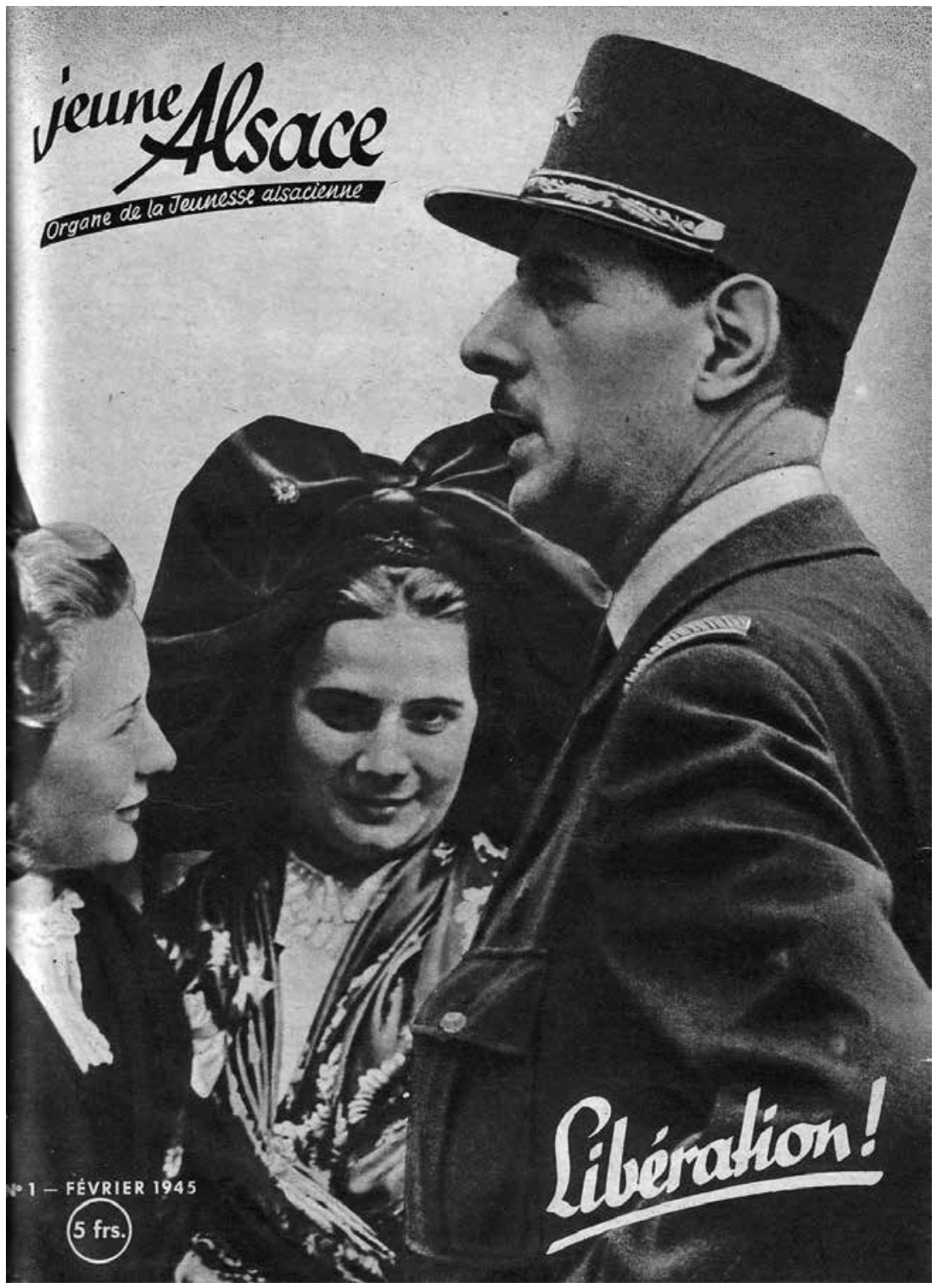

49 Jeune Alsace, $\mathrm{n}^{\circ} 1$, February 1945. 
At the same time, the Alsatian youth movements began to take on a more national than local dimension. While seeking to preserve their originality by maintaining a singular memory, they gradually strengthened their ties with the Parisian structures. Here they were encouraged by the Regional Inspectorate of Youth and Sports, which allocates subsidies for this initiative. The Young Christian Workers, Students and Farmers associations notably multiplied contacts with their respective federations during 1947 and 1948 and followed the national yearly campaigns, while the Catholic summer camps, hitherto governed by informal local leaders, joined the French union of summer camps. The majority of the youth organizations of Alsace thus progressed towards the idea of national harmonization, a guarantee of their public legitimacy.

Impacted by the fervour of the popular education current supported by a generation of activists convinced of the need to gather the people around their culture, ${ }^{50}$ the Alsatian movements developed between moments of euphoria and real difficulties. The Catholic and Unionist scout movements enjoyed their new-found freedom, as attested by the national councils of chiefs organized in Alsace between 1945 and 1948 and the buzz around their regional camps. The Young Catholic Workers became a mass movement whose activist dimension was strengthened through the meetings held in the summers of 1946 and 1947. Locally, however, the sections struggled to cope with the absence of their leaders who did not return from the war. Most of the movements restructured gradually, doing their best to deal with the lack of human and material resources. This was the case, for example, of the Young Christian Students and Farmers associations, the Jewish movements and the youth hostels.

The creation of the maisons des jeunes et de la culture (youth and cultural centres) between 1945 and 1948, the foyers ruraux and foyers-clubs, archetypes of popular education, gave impetus to these movements. These new youth institutions, which emerged across France at the initiative, notably, of Protestant socialist and democrat André Philipp, were intended to help citizens gain autonomy and take more responsibility for themselves through participation in cultural activities. ${ }^{51}$ They were designed as meeting venues and places for

50 Jean Joussellin, 'Les mouvements et les fins (finalités ou disparitions) de l'éducation populaire', in Geneviève Poujol, ed., Éléments pour l'histoire de l'éducation populaire (Marly-le-Roi: INEP, 1976), 115-130.

51 Laurent Besse, Les Maisons des jeunes et de la culture, 1959-1981 : de l'été des blousons noirs à l'été des Minguettes (Rennes : Presses universitaires de Rennes, 2008). 
sharing for young people, whatever the movements they belonged to. It was therefore important to ensure that links between youth movements were established within these centres. ${ }^{52}$ Based on the principles of participation and secularism, their aim was to bring the movements together within a traditionally compartmentalized environment. Their success confirmed the impression of a profusion, although locally nuanced, of initiatives for the youth of Alsace in the post-war period.

It is true that during the 1950s, the Alsatian movements experienced a golden age. They also cultivated the strong associative tradition of this region, inherited from the nineteenth century. Firmly established, between them they mobilized more than $10 \%$ of the Alsatian youth in 1960, when this figure was estimated at only $7 \%$ nationally. In a climate of appeasement of local interfaith relations, ${ }^{53}$ they contributed to the shared project of structuring a coherent public youth policy in Alsace, which effectively relayed the national guidelines of the High Committee for Youth in particular. ${ }^{54}$ Faced with the increasing concentration of resources and power characteristic of post-war France, the Alsatian movements exceeded their oppositions to move towards forms of cooperation that were new for them but already developed at the national level since the 1940s. The local scout associations, for example, met within a Regional Federation of French Scouting. The Protestant Youth Council of Alsace and the Protestant Youth Centre of Strasbourg, founded in 1952, became established as hubs for the unionist movements, in the same way as the Central Organization for Camps and Youth Hostels created in 1957 for Catholic organizations, the Alsatian delegations of the Eastern Jewish Youth for the Jewish movements, and the General Confederation of Secular Works for the coordination of lay movements. Thus grouped within organizations that aimed to support them in the face of social change, the youth movements of Alsace learned public dialogue and abandoned the exclusive search for singularity.

52 Interview with Jean Bézu, Regional delegate of the French Federation of the youth and cultural centres between 1958 and 1972 (January 29 ${ }^{\text {th }}, 2004$ ).

53 Alfred Wahl, 'Vers la fin des conflits interconfessionnels?', in Jean-Paul Willaime, ed., Vers de nouveaux œcuménismes (Paris : Cerf, 1989), 117-129.

54 Pascal Ory, 'Les premiers pas d'une politique démocratique de la jeunesse en France, 1944-1958', in Geneviève Humbert, ed., Jeunesse et État (Nancy : Presses universitaires de Nancy, 1991), 23-38. 


\section{A strained and distant relationship with the nation, 1958-1970}

From the late 1950s on, Alsatian youth movements experienced a paradoxical situation. While they sought to innovate to keep up with the young people of the day (introduction of mixed groups of young men and women, educational reforms within the scout movement to make it more technical, emphasis on the new youth and cultural centres, etc.), they also began to experience serious difficulties. Numbers fell significantly in most of the movements. Their structures, their very ideological foundations, started to be virulently contested by the generation of baby boomers who, reaching the age of responsibility, had no intention of conforming to the norm established by their elders. ${ }^{55}$ It was indeed a conflict of generations that essentially questioned the legitimacy of these movements.

The issue of commitment, notably, troubled this age group who struggled with the idea of joining a movement where, despite everything, adults occupied such a central role. Considered modern since the beginning of the century, youth movements thus started to be increasingly seen as backward and old-fashioned. Exposed to the individualistic and consummatory attitudes of young people, they seemed more and more out of step with emerging sensitivities. The gap widened between organizations that claimed to offer collective training and new expectations in terms of leisure, sociability and physical activity, which became increasingly individualized.

Major reports published by the coordination bodies of the movements in the early 1960s attested to this growing incomprehension. In 1960, the report commissioned by the Bishop of Strasbourg, Bishop Weber, on the state of the Catholic movements and the role of faith among young people in Alsace, highlighted certain worrying 'symptoms': the threatening progress of materialism and the 'technician mentality', the lack of commitment to a cause, the 'loss of the love of nature and of the mountains, of singing and of music', the inability of young people to 'imagine holidays that are spiritually uplifting', etc. ${ }^{56}$ The report encouraged the movements to redefine the role of the educator and the teaching methods used in order to 'interest today's young people, who live in conditions that previous generations have not known. On the face of it, the discourse of the Catholic Church

55 Jean-François Sirinelli, Les baby-boomers: Une génération 1945-1969 (Paris: Fayard, 2003).

56 Archives of the Bishopric of Strasbourg, Strasbourg. Bulletin ecclésiastique, $1^{\text {st }}$ July 1960. 
was one of progressivism. But it struggled to hide the failure of the movements to retain young people. Within the context of increasingly severe competition from other leisure activities (notably the sports movement), the majority of the Alsatian youth movements experienced their most serious growth crisis, as was also the case at national level.

They nevertheless tried to establish themselves regionally as key bodies, representative of the aspirations of young people. Inter-movement cooperation notably achieved a milestone in the 1957-1958 period with the creation of a network of pioneering structures in France: the Conseils départementaux de la jeunesse (Departmental Youth Councils). With the goal of getting young Alsatians 'more involved in the life of the department and the city', ${ }^{57}$ the Departmental Youth Councils united almost all of the youth organizations in the two departments of Alsace, as well as training representatives from trade and professional unions. Henceforth recognized as 'essential representatives of local associations' in the words of Claude Marx, troop leader with the Jewish Scouts in 1947 and the instigator, in 1957-1958, of the Departmental Youth Council of the Bas-Rhin which he presided until $1963,{ }^{58}$ these typically Alsatian structures, which would later spread to the rest of France, assumed a role of training (creating information centres for youth, organizing study days) and even management (distribution of departmental grants). By also communicating on their commitments, particularly the reserved position of the Alsatian movements with respect to the war in Algeria in 1961, the issue of socio-cultural facilities in 1964, or the principle of co-management (effective collaboration between government and youth organizations) in 1966, these coordination structures expressed the political maturity of movements that, regardless of the parties, claimed first and foremost to relay the views of young people. In this sense, the action of these structures homogenized that of the movements and changed their relationship to the State while maintaining their specificity. In a way, these structures allowed the Alsatian youth organizations to come together around common positions, claiming a certain joint local identity, beyond their traditional religious and/or political differences.

57 Departmental Archives of the Bas-Rhin (Strasbourg). 659.D.29. CDJ. Letter from the office of the CDJ to the prefect of the Bas-Rhin, 9 April 1958.

58 Interview with Claude Marx (January 29 ${ }^{\text {th }}, 2004$ ). 
Despite this, the relationships of the Alsatian movements with the State inexorably became more distant, which also played a major role in their alienation. Having been constructive since the Liberation due to the willingness of the State to provide a place for local movements within the framework of youth policy, ${ }^{59}$ these relationships gradually became more and more complex. In 1966, with the creation of a real Ministry of Youth Affairs and Sport, the State's aim was to establish itself more firmly in this area and thus no longer recognized the movements as representative of young people. Far from being conciliatory, Minister François Missoffe decided to pursue a policy that also bypassed the coordination bodies of the different movements. The key impact of this change in public youth policy was financial, the youth sector becoming a 'poor cousin' in budgetary choices. Promoting direct intervention, the State alone initiated specific actions, which notably included the creation of the Centres for Youth Information and Documentation (Centres d'information et de documentation jeunesse, CIDJ). While the resources allocated to these new structures increased significantly, at the same time those of the movements decreased. Less supported by the government, they nevertheless continued their activities, but undeniably lost their social impact. The youth movements in Alsace thus suffered from a crisis of legitimacy.

Called into question by both young people and the State, the Alsatian youth movements were significantly undermined towards the end of the 1960s. In terms of their content, they were forced to prioritize the individual over the group, the demand over the ideology; a tendency confirmed by the cultural revolution represented by the events of May 1968 in France. They thus abandoned some of their goals. In response, a number of so-called 'traditionalist' movements were created, particularly in scouting (Federation of European Scouts, Scouts and Girl Guides of Saint-Georges). These groups demanded a return to authentic scouting, considering that contemporary scouting misrepresented the original values of the movement. In terms of their place in the public eye, the youth movements were no longer in a position to influence the policies in place. Inevitably, they lost their vigour and their ability to oppose, where regional socio-political specificities had previously offered them a way to assert themselves. It was also at this time

59 Patricia Loncle, 'Histoire sans fin. Les jeunes et l'action publique', in INJEP, Les jeunes de 1950 à 2000. Un bilan des évolutions (Marly-le-Roi : INJEP, 2001), 255-277. 
that they abandoned almost definitively every regional aspect in order to better fit into national moulds.

\section{Conclusion}

In this 'small nation' that Alsace constituted between the early twentieth century and the 1970s, its youth groups form part of a unique history. Their relationships with the French government, highly dependent on the local political context, were situated between unconditional enthusiasm for integration into the French nation and a desire to retain local characteristics and specificities. While these latter evolved, they nevertheless remained very structuring for the youth movements, which claimed to train up a moral, critical and committed youth. The historical perspective allows for saying that the Alsatian movements gradually moved closer to the French State from 1918 on, and the trajectories of each of them thus tended to converge. Under the effect of the construction of a public intervention for youth after 1945, for example, the Alsatian movements became part of various national coordinating bodies and thus smoothed out their differences.

In all cases, the Alsatian youth movements played a civic role from 1918 on. They familiarized young people, in very specific ways depending on the time, with a culture, ways of thinking and common references perceived as belonging to all French youth. In this respect, they took on a role of 'schools of the nation', when one considers the nation, like Dominique Schnapper, more as a cultural than a political entity. ${ }^{60}$ In this sense, the history of the Alsatian youth movements demonstrates how the idea of nation was constructed in Alsace, a border region with a pronounced political history and cultural characteristics, between frank enthusiasm and hesitation.

At the end of this paper on the relationships of the Alsatian movements to the issue of national identity, their relationship with the German nation still remains to be addressed. Overwhelmingly pro-France in 1918, the Alsatian youth movements were at first completely impervious to Germany. The emergence of pro-German movements in the mid-1920s, politicized and separatist, only reinforced this attitude, even though the Deutsche Jugendbewegung, with Wandervogel at the head, had made Alsace and the Vosges an ideal hiking

60 Dominique Schnapper, La communauté de citoyens : sur l'idée moderne de nation (Paris : Gallimard, 2003). 
terrain between 1890 and $1910,{ }^{61}$ and that links could have been forged. Thus, while the German youth associations or hiking clubs experienced success in territories such as Eupen-Malmedy or Polish Silesia, Alsace remained somewhat impervious to these initiatives. The initial mistrust, which turned into total rejection with the establishment of the Hitler Youth, nevertheless evolved after 1945. While somewhat reserved in the immediate post-war period, the position of the Alsatian youth movements shifted in the early 1950s at the same time as the economic and political construction of Europe. With the building of a genuine 'European Youth Campaign', the Alsatian youth started to be gradually 'educated with respect to the Union.' ${ }^{62}$ If it met with great success at this time, it was primarily because this openness was seen as the key to consolidating the various movements and the Franco-German exchanges as a major development challenge, at a time when the legitimacy of these structures was starting to be called into question. Indeed, the mid-1950s was a time when most of the youth associations, faced with increasing competition from the sports movement, suffered from an outdated image and lost credit and representativeness among young people. Given this context, the opening up to Europe, a factor of progressive internationalization, started to be seen as a necessity within the Alsatian movements. With the creation of the FrancoGerman Youth Office in 1963, cooperation with the German youth movements became obvious for many.

Finally, what about the current situation of youth movements in Alsace? Some of them were unable to successfully integrate in their operations new societal trends in youth recreation and consumption, and consequently died out or almost during the crisis of 1960-1970. Others, however, made it through. In these cases, they often gave up on attracting as many young people as in the past, but renewed their style and their activities to meet the needs of a society different from that of the first half of the twentieth century. In particular, the majority of the Alsatian youth groups put the desire for regional specificity behind them. And while their methods have evolved, there nevertheless remains an imperative within them, that of the formation of conscience and behaviours. Led by officials convinced that the originality of their pedagogy has virtues which

61 Wandervogel Elsass-Lothringen, Gauverband für Jugendwandern, Satzungen ... für die Ortsgruppen Strassburg-Nord (Strassburg, 1912).

62 Jean-Marie Palayret, 'Éduquer les jeunes à l’Union : la campagne européenne de la jeunesse, 1951-1958', Journal of european integration history, 2 (1995), 47. 
other educational institutions cannot claim, the youth movements of Alsace have at least the essential merit of 'having been' and of having known, in their time, how to 'fulfil their historic function. ${ }^{63}$

63 Yvon Tranvouez, 'L'Action catholique, un échec religieux ? À propos des jacistes du Finistère', in Brigitte Waché, ed., Militants catholiques de l'Ouest. De l'action religieuse aux nouveaux militantismes, XIXe-XXe siècle (Rennes : Presses universitaires de Rennes, 2004), 196. 


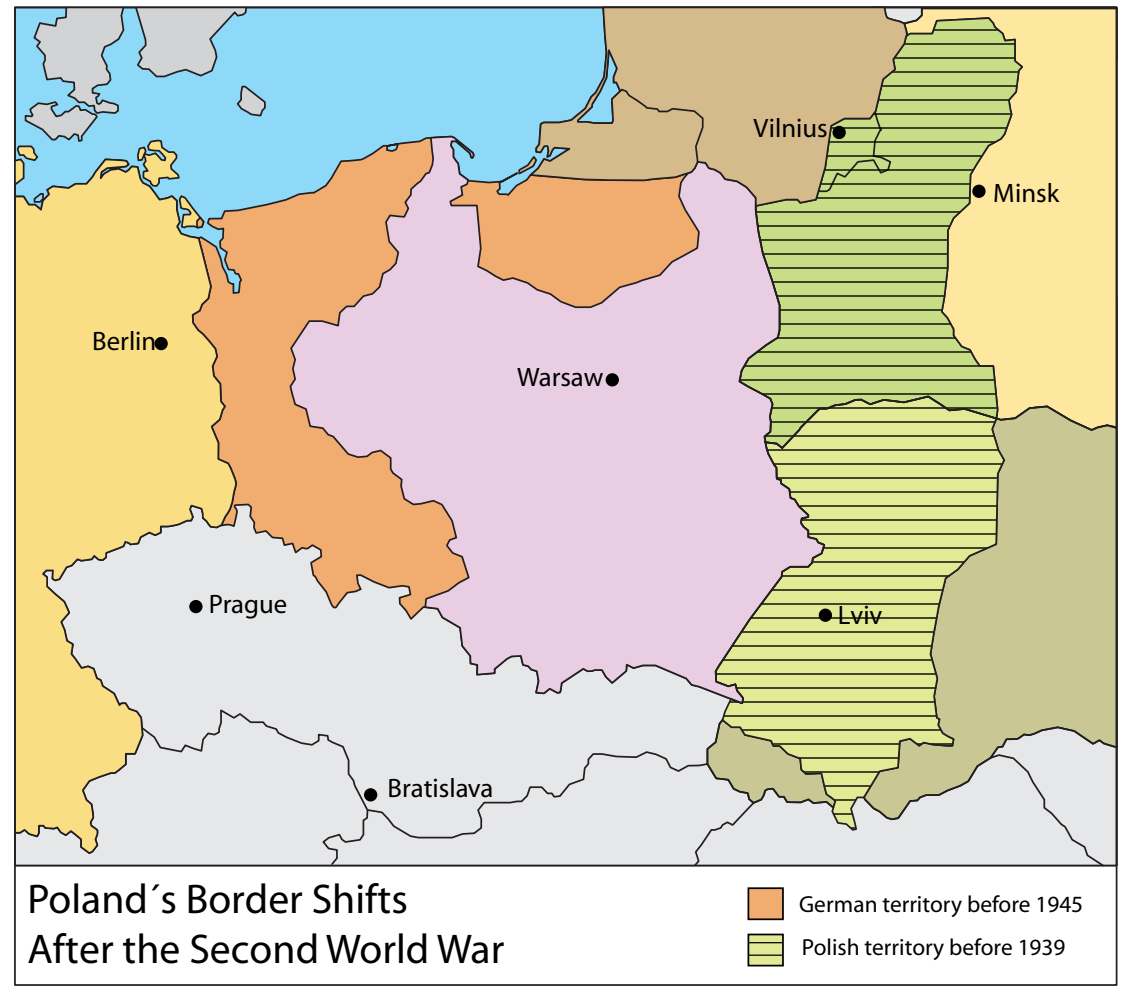

Map 4: Poland's Border Shifts After the Second World War. 


\title{
Beata Halicka
}

\section{The Everyday Life of Children in Polish-German Borderlands During the Early Postwar Period}

\begin{abstract}
The Polish-German border created in 1918, following Poland's regaining of independence, was moved approximately $200 \mathrm{~km}$ west in 1945. As a result of forced migration and, in many instances, the almost complete exchange of populations, this region experienced significant social transformation. In conducting my research on the everyday life of the inhabitants of this border zone, an important source was autobiographical documents, especially settlers' memoirs, mainly of Poles who had settled these regions following the war. This article presents conclusions resulting from working with these kinds of sources, with particular consideration regarding childhood memories and the mechanisms behind the construction of memory. The fate of children living in this region following the Second World War have been presented both from their own perspective and on the basis of testimonies of adults describing their family life, their work in schools or institutions in which they dealt with children and young people. Central issues include topics such as harsh living conditions, dealing with traumatic wartime experiences and their longing for a lost homeland, the beginnings of Polish education, the discrimination and exclusion faced by German-speaking children, as well as education conducted in a nationalist and patriotic spirit.
\end{abstract}

\section{Introduction}

During a meeting with German and Polish witnesses of the post-war period former and current inhabitants of Pyrzany in Western Poland born in the 1930s Adam I., a Polish man, and Roschen S., a German woman, told their stories. Roschen S. spent the first years of her life in Pyrzany when it was still called Pyrehne and was part of the German Reich. In summer 1945, together with her mother, she was forcibly expelled beyond the Oder by Polish soldiers. Adam I., however, spent his childhood in a Galician village in the east of Poland which, together with his family, he was forced to leave and settle in the German territories joined to Poland in 1945. As Adam I. describes, his homeland was a beautiful hilly land with fertile soils and a mild climate. After a long and tiring journey, Adam and his family reached the west of Poland. In their minds, their first and most enduring impression of this new and completely unfamiliar land was of the River Warta valley, which seemed to them to be a dull and flat landscape with poor sandy soils and overwhelming dampness, as well as a plague of mosquitoes, all of which convinced them that it was not fit for habitation. However, Roschen S. could not 
agree with such a negative portrayal of her little homeland. Finally, unable to hear any more of Adam's complaints, she interrupted him by indignantly shouting, 'But this is not true, as our homeland was so beautiful.' ${ }^{1}$

\section{Methodology}

This incident, which I witnessed in May 2011, shows how subjective our memory is and how strong the tendency is to idealize our childhoods. How, therefore, should one examine the history of everyday life when the autobiographical sources on which it relies to a large extent seem to be so unreliable? Above all, one should remember that the authors of all types of autobiographical accounts display only partly the reality they witnessed. Their accounts are constructions which, above all, reflect their system of values and attitude to life. That is why the contemporary historian who examines everyday life prefers to have access to many different autobiographical accounts referring to the same events, as well as confronting them with other historical sources. Thus, their aim is less to discover what happened but much more to unravel the subjectivity of people's experiences and memories.

In Poland, sociological and social-historical research on everyday life began in the 1920s. Indeed, the well-known Polish sociologist Florian Znaniecki developed a method of memoir competition after returning from a research stay in Chicago following the First World War. The central idea was to collect submitted diaries, testimonies and autobiographies - life writing - from ordinary people. Scholars then produced analysis and often compiled volumes, in which academic introductions were followed by life records and correspondence, as extensive extracts or full versions, intertwining analysis and autobiographical extracts. ${ }^{2}$ Although qualitative sociological research became a popular phenomenon in the Polish memoir boom of the late 1950/60s, it faded in the mid-1970s, just as western scholars associated with British oral history or French biographical sociology

1 See results of an oral history project under my supervision called 'Germans, Poles and Ukrainians on the path of remembrance of forced migration' financed by the Europe for Citizens Program available at: www.pyrzany-kozaki.eu (last visited 5 February 2016) and in: Beata Halicka, Bogusław Mykietów, eds., Kozaky - Pyrehne. Polen, Deutsche und Ukrainer auf dem Erinnerungspfad erzwungener Migrationen / Kozaki - Pyrzany. Polifonia pamięci o przymusowych migracjach we wspomnieniach Polaków, Niemców i Ukraińców (Skórzyn: Wydawnictwo Instytutowe, 2011).

2 William I. Thomas, Florian Znaniecki, The Polish Peasant in Europe and America, 5 vol. (Chicago and Boston: Richard G. Badger, The Gorham Press, 1918-1920). Complete 5 volume available at: http://chla.library.cornell.edu/c/chla/browse/title/3074959.html (last visited 5 February 2016). 
became the focus of interest on it. ${ }^{3}$ In Germany, Alf Lüdtke ${ }^{4}$ was the most important representative of research on everyday life. In the 1980s, however, Poles returned to their rich tradition, above all, through the works of Tomasz Szarota on everyday life in occupied Warsaw, as well as to the works of Marcin Kula. ${ }^{5}$ Their innovation was that the subject of their historical research included not only processes, structures, facts and dates, but also human emotions, life stories and individual experiences. Thus, oral witness accounts, as well as written autobiographical documents, became an important source and were subject to the same criticism of sources as occurs regarding traditional archival research. ${ }^{6}$ At the same time, it is worth paying particular attention to the fact that memoirs, either written or related orally soon after the event, as well as those recorded after several years, differ from those recorded half a century later, for example. This time gap causes us to quite often unconsciously mix our own experiences with facts that we have heard about or we have read somewhere else. ${ }^{7}$ Moreover, the so-called 'official' version of history imposes itself on the presentation of one's own memories in order for social expectations to be fulfilled:

This refers to the description and evaluation of every event. The longer the time distance is, the vaguer particular elements and themes become. Thus, as a source the value of these accounts decreases as they have an exceptionally subjective character. After fifty years or more witnesses often remember the events that were particularly emotionally

3 Paul Andrew Vickers, 'Peasants, professors, publishers and censorship: memoirs of rural inhabitants of Poland's recovered territories (1945-c.1970)', $\mathrm{PhD}$ thesis, University of Glasgow, 2014, available at: http://theses.gla.ac.uk/4821/ (last visited 5 February 2016).

4 Alf Lüdtke, ed., Alltagsgeschichte. Zur Rekonstruktion historischer Erfahrungen und Lebensweisen (Frankfurt am Main-New York: Campus-Verlag, 1989).

5 Tomasz Szarota, Okupowanej Warszawy dzień powszedni: studium historyczne (Warszawa: Czytelnik, 1973); Tomasz Szarota, Warschau unter dem Hakenkreuz. Leben und Alltag im besetzten Warschau 1.10.1939 bis 31.7.1944, (Paderborn: Schöningh, 1985); Marcin Kula, Krótki raport o użytkowaniu historii (Warszawa: PWN, 2004); Piotr T. Kwiatkowski, Lech M. Nijakowski, Barbara Szacka, Andrzej Szpociński, Między codziennością a wielką historią. Druga wojna światowa w pamięci zbiorowej społeczeństwa polskiego (Gdańsk-Warszawa: Scholar 2010).

6 Heinke M. Kalinke, ed., Brief, Erzählung, Tagebuch. Autobiographische Dokumente als Quellen zu Kultur und Geschichte der Deutschen in und aus dem östlichen Europa (Freiburg: Johannes-Künzig-Institut für ostdeutsche Volkskunde, 2000), $7 \mathrm{f}$.

7 Hans J. Markowitsch, Harald Welzer, The Development of Autobiographical Memory (Hove and New York: Psychology Press, 2009). 
strong, thereby losing their capability of assessment. Moreover, they frequently lose the ability to place them in time. ${ }^{8}$

Therefore, while researching post-war everyday life it is recommended to look for ego-documents written in the 1940s and 1950s or seek out those which were based on prior notes, diaries or letters. ${ }^{9}$ Admittedly, such documents were written in a communist context, that is, under social or even political pressure. However, they are distinguished by their paying more attention to detail and presenting the problems, concerns and joys which were important then and which today have frequently lost their significance. Although they usually contain a subjective and biased viewpoint, full of stereotypical evaluations, they include a huge amount of information on the way of thinking and acting, living conditions and the external circumstances which the witnesses of the period had to face. Using these sources for research on the wartime and post-war experiences of children is particularly important due to the fact that the witnesses of the period who are still alive today were young children during the Second World War. Even if they possibly managed to remember much of those events, their account will be either the perspective of a child or will become a construction in which it is not their experiences that will dominate but information received from others, often with a large time gap.

In examining the fate of children and youths in the western territories of Poland during the early postwar years, one must take into account the specific nature of the border region which came into being in 1945 as a result of border changes, as well as the specific nature of a population affected by the experience of forced migration. Here, one will discuss both the German civilian population forced to evacuate, flee, or later suffer expulsion from their homelands, as well as newly arrived Polish settlers, many of whom had come to these regions unwillingly. In the case of the young inhabitants of this region which interest us, one will discuss, above all, the orphaned German children who stayed on in the Oder basin region for various reasons, as well as the children of settler families who arrived here accompanied by their closest relatives. In most cases, such children had also been scarred by war, had lost family members and, for a long period, neither had proper living conditions nor opportunities for education. Therefore, the taking on of such research perspectives allows the consequences of relocated borders and forced migration to be closely examined. Indeed, by relying on examples of the

8 Bernadetta Nitschke, Wysiedlenie ludności niemieckiej z Polski w latach 1945-1949 (Zielona Góra: Wydawnictwo Wyższej Szkoły Pedagogicznej, 1999), 19.

9 Barbara Kubis, Poznawcze i kształcące walory literatury dokumentu osobistego (Opole: Uniwersytet Opolski, 2007), 74. 
fates of individual children and youths, it is possible to show these consequences in a long-term context as their stories were recorded with a certain time gap, thereby enabling certain conclusions to be reached and each individual's fate to be evaluated. Moreover, the youngest generation was the subject of education in line with the establishment of a new government in this region. As Marcin Zaremba has shown, this was an exceptional combination of national and communist ideals. ${ }^{10}$ Both through school and the organization of leisure time, significant influence was gained over children and youth which frequently imposed views in conflict with those handed down in families. On the other hand, the communist system guaranteed educational opportunities at all levels, including the children of the lowest social classes, thereby gaining support from this section of society. ${ }^{11}$

\section{Historical background of the region over the long twentieth century}

The eastern regions of Germany which were joined to Poland due to the Potsdam resolutions of August 1945 had been ruled by Germany for many centuries. Along with the partitions of Poland at the end of the eighteenth century, the Prussian state also acquired the Wielkopolska region and so-called West Prussia which was situated even further east. It was not until the early twentieth century that the Oder became a border region. When, in 1918, the Polish state regained its independence, Germany had to return a significant part of its Prussian provinces in the east. Upper Silesia was divided, while on the basis of the Treaty of Versailles, the Oder, which for nearly two centuries had been a Prussian river, now became an international waterway. It was, however, styled as a 'German' river or more properly 'a river of the German East.' ${ }^{12}$ The decisions which were made at Versailles inflamed the political mood: historical justifications were sought for German revisionist claims towards Poland, as well as the rights of the German minorities in Poland. ${ }^{13}$ When, through brutal might, Germany, as the Third Reich, once

10 Marcin Zaremba, Komunizm, legitymizacja, nacjonalizm. Nacjonalistyczna legitymizacja władzy komunistycznej w Polsce (Warszawa: Trio, 2001).

11 Marek Wierzbicki, Młodzież w PRL (Warszawa: Instytut Pamięci Narodowej, 2009).

12 According the Eastern border of Germany see: Klaus Zernack, 'Deutschlands Ostgrenze', in Alexander Demandt, ed., Deutschlands Grenzen in der Geschichte (München: C. H. Beck, 1991), 140-165; Jan Maria Piskorski, '1000 Jahre der deutsch-polnischen Grenze', Jahrbuch für die Geschichte Mittel- und Ostdeutschlands 44 (1996), 129-150.

13 Jörg Hackmann, 'Deutsche Ostforschung und Geschichtswissenschaft', in Jan M. Piskorski, ed., Deutsche Ostforschung und polnische Westforschung im Spannungsfeld von 
again took control of significant territories of the Polish state, thereby creating its own General Government, police forces and protectorates, over two million Polish forced labourers were sent to the Reich proper and thus, also to the regions along the Oder. ${ }^{14}$ At the moment of the defeat of Nazi Germany, the eastern front which had been planned to reach as far as the Volga, was moved westwards by the Allies to the Oder and Neisse rivers. This fact led to the fall of Prussia and the German Reich which was accompanied by an ethno-demographic revolution in the form of the flight, expulsion and forced migration of the German population. The effect of these events was to lead to the radical metamorphosis of the Oder border regions. ${ }^{15}$

The historical regions of Brandenburg and Pomerania, as well as part of Silesia, were divided while the Oder entered the canon of terms of official political language. Indeed, it became part of the abbreviated term 'the Oder-Neisse line', the trademark of the Yalta Agreement. ${ }^{16}$ On this occasion, the new power arrangements in Europe gave Poland the opportunity to sanction its own territorial claims through the circulation of a range of myths, namely: the characteristic German 'Drive to the East', centuries-old German cultural and military aggression, as well as the reconstitution of Poland within the 'natural borders' of the territory ruled by Poland's Piast dynasty at the turn of the first millennium. ${ }^{17}$ Thus, the terms 'German eastern borders', 'the borders of the German East', as well as 'the western borders of Poland' are loaded with ideological meaning.

Wissenschaft und Politik. Disziplinen im Vergleich (Osnabrück: fibre Verlag 2002), 25-46, here 31 onwards.

14 Valentina Maria Stefanski, 'Polnische ZwangsarbeiterInnen in Deutschland. Anmerkungen zum Forschungsstand und zu Perspektiven der Forschung, Inter finitimos 6 (2008), 82-100.

15 Karl Schlögel,'Odra - przemyślenia na temat miejsca pewnej europejskiej rzeki w historii kultury', in Karl Schlögel, Beata Halicka, eds., Odra-Oder. Panorama europejskiej rzeki (Skórzyn: Wydawnictwo Instytutowe, 2008), 19-39, here 35 onwards.

16 Wojciech Roszkowski, Cień Jałty. Raport (Warszawa: Muzeum Powstania Warszawskiego, 2006); Tadeusz Marczak, Granica zachodnia w polskiej polityce zagranicznej w latach 1944-1950 (Wrocław: Wydawnictwo Uniwersytetu Wrocławskiego, 1995).

17 Examples include: Zygmunt Wojciechowski, Polska - Niemcy. Dziesięć wieków zmagania (Poznań: Instytut Zachodni, 1945); Maria Kiełczewska, Andrzej Grodek, OderNeisse, die beste Grenze Polens (Stuttgart, 1949) (Polish edition: Maria Kiełczewska, Andrzej Grodek, Odra-Nisa, najlepsza granica Polski (Poznań: Instytut Zachodni, 1945)); Kazimierz Golczewski, Tysiąc lat nad Odrą i Bałtykiem (Szczecin: Instytut Zachodnio-Pomorski, 1966). 
The lands to the east of the Oder and Western Neisse became places of almost complete population exchange, the severing of the cultural continuity of one society and the creation of new traditions and communities. This concerned, in particular, the lands situated in the central and lower Oder. Approximately 50 per cent of the German population fled the region due to the approaching eastern front while the remainder were either expelled between June and July 1945 or forcibly migrated during the following months and early postwar years. Before the war these regions had been inhabited by almost 8.5 million people, mainly Germans. The Polish share of the population in 1931 comprised 8.7 per cent and lived primarily in Upper Silesia and southern East Prussia. ${ }^{18}$

The settlement of Polish populations was a process which ran parallel to the forced migration of the German inhabitants. Propaganda campaigns aimed at encouraging settlement were already begun by the Provisional Government of the Republic of Poland during the first months of 1945, thus long before the final decision regarding the Oder-Neisse line. Plans for coordinated settlement campaigns were replaced in April 1945 with a decision to allow uncontrolled or 'wild' campaigns aimed at settling the greatest number of people in the regions concerned in the shortest possible time. This was a consequence of the loss of 46 per cent of Polish territory, according to its 1938 borders, to the Soviet Union and the resulting necessity to accelerate the transfer of the Polish population from the eastern borderlands, known as the Kresy.

The Polish authorities decided to commence the settlement of the former German lands without waiting for a formal decision from the Allies on the matter. Indeed, a Polish presence in these regions was meant to be one of the decisive arguments at a future peace conference. Both operations were conducted under the pressure of Soviet faits accomplis in conditions insufficient for organisational readiness. These plans gave way to improvisation and their uncontrolled implementation due to which many thousand people experienced material losses, suffering, disease and even death. One consequence of these decisions was the chaos which governed during the first few months, combined with an invasion of looters and enormous fluctuations in population. The statistics which were presented by the Polish government at the end of 1945 were meant to display significant progress in the settlement campaign. However, they did not describe entire transports comprising tens of carriages packed with people who were sentenced to spend

18 Grzegorz Hryciuk and Witold Sienkiewicz, Zwangsumsiedlung, Flucht und Vertreibung 1939 bis 1959. Atlas zur Geschichte Ostmitteleuropas (Bonn: Bundeszentrale für politische Bildung, 2009), 16. 
weeks vegetating at railway stations or in open fields, deprived of the most basic care and transported to the wrong destinations or forced to return.

The lands east of the Oder and Western Neisse joined to Poland in 1945 were subsumed by a multitude of organizational and economic problems whose solution constituted a major challenge for the Polish state during the years following the war. This caused many difficulties, especially during the first months of 1945 when the Provisional Government of the Republic of Poland was limited in asserting its rights by the Soviet military authorities and the lawlessness of certain Red Army commanders. Other serious problems occurred concerning staffing, a lack of transport resources and supplies.

The activities of both government and non-government organizations dealing with the problems of the new territories, along with the lack of a clear division of tasks, caused incidents of overlap and organizational chaos. This phenomenon was affected additionally by the battle between the main rivals for government power, namely the Polish Peasants' Party (PSL) ${ }^{19}$ and the Polish Workers' Party (PPR), ${ }^{20}$ which intensified during the second half of 1945 . The latter, employing Soviet support, gained a significant advantage which allowed it to establish, on 13 November 1945, the Ministry for the Recovered Territories to be headed by Władysław Gomułka, the Secretary General of the PPR and Deputy Prime Minister of Poland. ${ }^{21}$ The scope of operation of this ministry, in fact, encompassed all areas of social and economic life of these regions.

The first settlers in the regions concerned were Poles who had followed just behind the westward-advancing Red Army and who, either arbitrarily or with the approval of Soviet commanders, took on the roles of representatives of the Polish administration. Quite often such people took advantage of the situation to enrich

19 PSL was the main non-communist rival of the Polish communist movement and enjoyed much greater popular support, especially among Poland's farmers. Between 1945 and 1947, the communists conducted a concerted campaign to destroy the PSL, eventually forcing its leader, Stanisław Mikołajczyk, to flee the country in late 1947.

20 The Polish Workers' Party was the cover name of the Polish communist movement whose leadership was largely Moscow-trained and directed. Following its destruction of the PSL in 1947, it absorbed its remaining rival, the Polish Socialist Party, into a Polish United Workers Party (PZPR) in the following year.

21 Władysław Gomułka, espoused 'National Communism' which sought to reconcile Marxism-Leninism with traditional Polish national aims for self-determination and less direct control from Moscow. In 1948, as the Stalinist wing of the PPR gained control, Gomułka experienced a spectacular fall from grace and narrowly avoided execution. His equally spectacular return to power following the post-Stalinist thaw of 1956 provided a basis for the PZPR to continue its rule for several decades to come. 
themselves, loot property left behind by fleeing Germans and then sell it on in so-called central Poland. It is difficult to call such people 'settlers' as usually they did not stay long in one location and frequently changed their place of residence. More deserving of the term 'settlers' are the inhabitants of neighbouring border counties who moved, as a rule, from not very far away and occupied abandoned German farms. At an earlier stage, one may come across Polish forced labourers or groups returning from POW or work camps in Austria and Germany. The Provisional Government of the Republic of Poland attempted to encourage POWs and forced labourers to settle in these regions.

The movement of settlers reached its peak in May 1945, thus following the capitulation of Germany, from which time one may already speak of a more or less organized campaign. Special shuttle trains were inaugurated by which settlers from the further regions of central Poland arrived. However, due to insufficient rolling stock, a section of the population, mainly those from neighbouring regions, managed to reach the western and northern territories by horse-drawn vehicles or even on foot.

From spring 1945 the regions along the Oder had begun to receive settlers from the formerly Polish eastern borderlands. This was carried out on the authority of an agreement concerning population exchanges which the Polish Committee for National Liberation, an organization created by Polish communists, signed with the governments of the Ukrainian, Byelorussian and Lithuanian Soviet republics in September 1944. Indeed, the first transports of expellees left Byelorussia and Ukraine by the end of 1944 while from Lithuania they departed in January 1945. Between 1944 and 1948, over 1.1 million Poles were 'repatriated' from east to west. Additionally, after 1955, over 250,000 Poles returned from Siberia and other territories of Soviet Union and settled in the west of Poland. Moreover, the holocaust left only about 160,000 Polish Jews, mostly in Soviet territory, and who on their return to Poland were settled in the western territories. Indeed, in July 1946, 80,000 Jews were living in Lower Silesia while about 30,000 were based in West Pomerania. ${ }^{22}$ However, most Jews did not stay in western Poland after 1945 and moved abroad.

Those inhabitants of central Poland and Wielkopolska deciding to settle in the western and northern territories had to have a settler's certificate issued by their local county council, on the basis of which they received free transportation and food. Although the settlers were forced to pay for any properties they occupied in

22 All statistics based on: Witold Sienkiewicz, Grzegorz Hryciuk, Wysiedlenia wypędzenia i ucieczki 1939-1959. Atlas Ziem Polski (Warszawa: Demart, 2008). 
the new territories, the terms of repayment were spread over ten years and based on favourable conditions. Farmers usually repaid this money through agricultural produce. Moreover, Poles returning from German concentration camps and staying on in the western territories were considered as settlers or expellees and received appropriate settler certification or, in the case of those who came from the regions absorbed by the USSR, a certificate of compensation aimed at replacing their property.

The new society of Poland's western territories arose, and was noted for its particular mixture of cultures and traditions. It comprised three main groups, classified according to their background, namely: settlers from central Poland and Wielkopolska (48.9 per cent), expellees from the territory annexed by the Soviet Union (27.7 per cent), as well as the so-called autochthons, the indigenous inhabitants of these lands (19.7 per cent). ${ }^{23}$ The percentage share of certain groups varied from region to region. Moreover, apart from these three groups, one must also mention those Poles who had emigrated either before or during the Second World War and, following 1945, had decided to return to their homeland. These officially-termed 're-emigrants' comprised less than 4 per cent of the general settler population. ${ }^{24}$

Although one of the main Polish political goals during the postwar years was to build national unity, one must however emphasize that within the new territories there were also those who represented other national groups. The late 1940s and early 1950s saw the German share of the population at its height, although attempts were made to camouflage their number in official statistics by classifying them as 'Polonised Autochthons.25 ${ }^{25}$ Moreover, in 1947, as part of 'Operation Vistula, over 136,000 ethnic Ukrainians were forcibly resettled in the western and northern lands. For the new inhabitants of the Oder region, the moment of their arrival, confrontation with strangers, and facing life in a depopulated land were all important experiences. The archival documents provide us with information

23 National census conducted on 3.12.1950, taken from Robert Skobelski, Ziemie zachodnie i północne w okresie realizacji planu sześcioletniego 1950-1955 (Zielona Góra: Redakcja Wydawnictw Humanistyczno-Społecznych UZ, 2002), 33; Patrycy Dzierżyński, Osadnictwo rolne na Ziemiach Odzyskanych (Warszawa 1983), 253.

24 National census conducted on 3.12.1950, taken from Robert Skobelski, Ziemie zachodnie i północne w okresie realizacji planu sześcioletniego 1950-1955 (Zielona Góra: Redakcja Wydawnictw Humanistyczno-Społecznych UZ, 2002), 33.

25 Hugo Service, Germans to Poles. Communism, nationalism and ethnic cleansing after the Second World War (New York: Cambridge, 2013). 
as to how the transport and distribution of people in homes and farms were organized. Knowledge of how these new arrivals felt during their first days there and how they managed in new surroundings is to be found in memoirs written during the early post-war years.

\section{Settler memoirs as a historical source}

My research was based on both archival documents gathered in the Polish National Archives in Szczecin, Zielona Góra and Warsaw and on the subject literature, as well as on settler memoirs. Following the Second World War various institutions (mainly research institutes, as well as cultural institutes and newspaper editors) announced competitions for the best memoirs in Poland's northern and western territories. Indeed, the so-called 'memoirs to order', resulting from several competitions held by the Western Institute in Poznań, may be considered some of the most interesting and broadest in scope. This institute was the leading research institution on Germany and the Recovered Territories, while pioneering the revival of memoir sociology through the sociologist Zygmunt Dulczewski, who himself had been a student of Florian Znaniecki. The aim of the institute was both the roles of conducting academic research and popularizing its findings.

Following 'the political thaw' which took place in Poland after $1956,{ }^{26}$ Polish sociologists from the Western Institute came up with an initiative for the first competition for gathering the memoirs of the Polish settlers of the so-called 'Western Lands' or 'Recovered Territories. ${ }^{27}$ Later competitions took place in 1966 and 1970 in which the respondents were asked about their experiences during and following the war, about their reasons for settling in the 'Recovered Territories', about the course of settlement itself, as well as about the first years in their new place of residence. Insofar as the texts sent to the competitions of 1966 and 1970 were dominated by rhetoric full of socialist propaganda, those from the late 1950s were written in the spirit of the October 1956 changes and are characterized by more freedom of thought, a critical assessment of reality and an openness in describing

26 The so-called 'Polish October', the climax of a process which began Stalin's death in March 1953 and eventually led to a wave of de-Stalinization, the release of thousands of political prisoners and a loosening of state censorship in late 1956. It also brought about the return of Władysław Gomułka and his policy of 'National Communism.'

27 Selected and censored memoirs appeared in the anthology: Zygmunt Dulczewski, Andrzej Kwilecki, eds., Pamiętniki osadników Ziem Odzyskanych (Poznań: Wydawnictwo Poznańskie, 1963 and 1970). 
mistakes and failures. ${ }^{28}$ For this competition 229 testimonies were entered 205 of which were accepted into the competition, the remaining 14 deemed not to have conformed to the criteria of the competition.

When analysing these memoirs regarding the fate of Polish children, one should state that only very few of these concern people who, in 1945, were still children. Most of the entries for the competition were sent by people who had already started new lives by the Oder as adults. In their accounts often appear children about whom they write as parents, teachers, representatives of local government or medical services. When portraying the situation of children in this region after 1945 one should therefore distinguish between sources written from the perspective of a child and those from the perspective of an adult. The topic I have researched could be deepened by taking into consideration memoirs sent for the second edition of the competition in 1966, which was addressed to the young generation of those living in the 'Recovered Territories' who had been born during the closing years of the war or just after it. However, as most of the entries sent for this competition were written in the spirit of the propaganda of the time, I did not take them into account. Indeed, the flourishing of research after 1956 began to fade in the later 1960s, as official policy gradually shifted towards declaring the 'Recovered Territories' fully-integrated with Poland.

\section{First months after arrival}

The situation of Polish settlers in the 'Recovered Territories' was so peculiar as here we are not only dealing with a group of forced migrants who settled in a new place and had to get used to living in a different society. In this way a completely new society came about in which, in a heavily war-affected region, it had to create structures of authority, schools, social and cultural institutions, as well as rebuild factories and organize agricultural production. It is no wonder that the first years were quite chaotic as not everything could have been organized at once. Many settlers came to the west in order to loot, get rich quickly and not necessarily to

28 An anthology of uncensored memoirs was published in German under my editorship.: Beata Halicka, ed., 'Mein Haus an der Oder'. Erinnerungen polnischer Neusiedler in Westpolen nach 1945 (Paderborn, Schöningh, 2014). The Polish edition was published in Kraków in 2016, entitled: Mój dom nad Odrą. Pamiętniki osadników Nadodrza po 1945 roku. (Kraków: Universitas, 2016). 
work for the common good. This is why my latest book, devoted to the subject of the Oder basin during the initial post-war years, is entitled The Polish Wild West. ${ }^{29}$ Stanisław Jędrzejowski who had fought in the Warsaw Uprising, arrived in the Western Territories in the early 1945 and took part in the foundation of the Polish administration in the town of Szczecinek in Pomerania. He describes the view of the city in spring 1945 in the following manner:

The destruction left by the war in this area was immense. Ruins and rubble and those walls still standing were blackened by smoke. The streets and cobbles were torn up by bullets or trenches and the pavements were buried under debris. [...] Life had come to a halt in the full meaning of this word and began to awaken again only a couple of weeks later. The permanent inhabitants [Germans - B.H.] who had remained in the town returned to the streets after a couple of days. The first signs of new life after the Soviet Army had passed through on their way west were the newly-arrived settlers from Central Poland. The majority of these were so-called looters who were not afraid of anything and acted on the principle to take everything that wasn't nailed to the ground, to rob everything and take it away. [...] All of this happened at a time when there were still no civilian administrative bodies. Life was uncontrolled and there was a lot of injustice. Delinquent acts were committed without inhibitions, and everything could be bought for home-made moonshine and vodka. Soviet soldiers were selling the horses and cattle they were driving eastwards. [...] The town at the time looked strange as it was divided into two parts. The Soviet part was occupied by the Soviet army and the Polish part was where the settlers settled down. At the time each street offered a peculiar sight. People moved quickly and furtively $[\ldots]$ and there were no children to be seen on the streets. ${ }^{30}$

The author of the above-quoted memoir focuses on the havoc which had been brought by war. In contrast to the widely circulated views that Poles were finding fully fitted-out farms in these regions, even with the proverbial still-hot soup standing on the stove, the reality was frequently different. Following the advance of the eastern front, the stationing of Red Army units for long periods, along with the initially completely haphazard nature of the conduct of the Polish administration and the incompetence of those assigned with conducting it, most towns and villages, as a rule, were found to be in a very poor state. Indeed, if they had not been destroyed by wartime activities, they were plundered, any livestock either

29 Beata Halicka, Polens Wilder Westen. Erzwungene Migration und die kulturelle Aneignung des Oderraumes 1945-1948 (Paderborn, Schöningh, 2013). A Polish edition: Beata Halicka, Polski Dziki Zachód. Przymusowe migracje i kulturowe oswajanie Nadodrza 1945-1948 (Kraków: Universitas, 2015). This project has been financed by the Polish-German Foundation for Research.

30 Memoir of Stanisław Jędrzejowski, P10/1957, 40, Archive of the Western Institute, Poznan. 
slaughtered or carried off, while food and seed stores were used up. As a result, the situation of the new Polish settlers was not easy. While many of them, it is true, received a roof over their heads and their occupation of living quarters was frequently organized for them, those arriving later found that the home awarded to them had most often been completely stripped of its furniture and fittings. The promised government help not only arrived with great delay but was inadequate which resulted, in fact, in many families starving during the winter months. ${ }^{31}$ In the towns and cities, the Soviets usually asset-stripped factories, workplaces and confiscated valuable objects from private homes. The new inhabitants faced the task of having to start from scratch regarding reconnecting water and electricity supplies, along with food provisions and the cleaning-up of ruined towns and cities. In fact, it was several years before urban life returned to normal. Moreover, interpersonal problems were not lacking with most conflicts igniting over the awarding of homes, workshops and shops. It was not until autumn 1945 that a more precise outline of tasks for certain government offices and courts appeared.

\section{My typology of settlers}

The initial post-war years in Poland witnessed a battle for government power and, as a consequence, a social revolution took place and a communist regime was introduced by force. All of these changes also left a significant impact on the lands joined to Poland in 1945. Thus, the settlers' memoirs open an insight into the social acceptance of these changes, as well as into the attitude new inhabitants of the Oder region had towards propaganda claiming 'the settlement has been completed successfully'. In my book The Polish Wild West I have divided the settlers of the 'Western Lands' into three groups depending on their attitude towards the new political situation and adopted the following three typologies of people:

- highly enthusiastic pioneers of the 'Recovered Territories'

- looters, or 'resourceful entrepreneurs' of the Polish 'Wild West'

- exhausted war victims and settlers yearning to return home.

Many Poles, mainly those from central Poland and the province of Wielkopolska who, to a greater or lesser degree, voluntarily decided to settle here, honestly believed in the declared right of Poland to the 'Recovered Territories.' This was in accordance with the notion that the Poles had regained these territories after centuries-long sacrifice as an act of historical justice. The Second World War, as

31 Zaremba Marcin, Wielka Trwoga, Polska 1944-1947. Ludowa reakcja na kryzys (Kraków: Znak, 2012). 
well as the German occupation, were seen as the crescendo of a thousand-year struggle' between Germany and Poland, ${ }^{32}$ which would lead to a righting of the balance for the traumatic experience of the past.

During the first years of the post-war period, looting was a widespread phenomenon. Due to great movements of populations, as well as the lack of a stable administration, a very specific situation occurred in the Oder region. Indeed, the enormous amount of goods and possessions which had been abandoned by their former owners and left unsupervised could very easily be appropriated by others. Moreover, from a legal standpoint, looting belonged to a 'grey area' and was accepted and practiced by the majority of the new Polish society. It became one of the daily activities performed not only by criminals but also respectable people with the best intentions. Virtually in all the memoirs which I have examined, the subject of looting comes up sooner or later. Looters undoubtedly belong to these groups of new inhabitants of the Oder region who found themselves well-off in difficult initial conditions. In fact, it was no longer than two or three years before most of those involved in such activities ended up in prison or were forced to flee in order to save themselves. For others, however, looting created a material basis of a new life which stabilized with time.

From spring 1945 refugees and expellees from the eastern borderlands of Poland began to arrive in the Oder region. They had endured a journey of several weeks in freight wagons, often having already suffered the trauma of the Soviet and German occupations, ${ }^{33}$ as well as the Polish-Ukrainian civil war. ${ }^{34}$ On their arrival at their destination most of them found themselves in a state of culture shock. Depending on their physical and emotional state of well being, they found their place in their new environment and began to engage with it, albeit at different tempos. Some people shut themselves away in their private life, isolated

32 See the political text by Zygmunt Wojciechowski, Polska - Niemcy. Dziesięć wieków zmagania (Poznań: Instytut Zachodni, 1945).

33 Germany and the Soviet Union invaded Poland in a coordinated campaign in September 1939 and divided the country between them. Eastern Poles found themselves under Soviet rule until June 1941 when Hitler launched Operation Barbarossa and eastern Poland endured Nazi rule. This changed again back to Soviet rule during the latter stages of the war as the eastern front moved westwards and eastern Poland was permanently absorbed into the Soviet Union.

34 A conflict which existed almost as a separate war within the Second World War, it featured extreme Ukrainian nationalists using the period of wartime destabilization to massacre tens of thousands of Poles in the provinces of Galicia and Volhynia in an effort to ethnically-cleanse Ukraine, peaking in 1943. Polish retaliatory killings amounted to at least several thousands, although wildly diverging figures are claimed by both sides. 
themselves from others, thereby losing the possibility of satisfying their need for recognition, social contact or self-development. Frequently, this had a negative impact on their health with some sitting on their unpacked suitcases for years afterwards or reliving the trauma of war.

In Polish memoirs from the late 1940s and 1950s it is difficult to find accounts concerning such human tragedies. Indeed, they did not suit the communistic ethos of the settler whose was meant to be actively involved with the resettlement and economic growth of the Oder region. Although it is true that criticism of shortages, mistakes and failed projects was tolerated 1956 (even if such critical texts were mostly not published and therefore remained unknown to the public sphere), it was rare, however, that someone presented this from the point of view of victimhood. The authors of the memoirs sent to the Western Institute in Poznan did not write (or wrote only indirectly) about their own suffering, longing for home, apathy or the life which they had lost.

Settlers who, to some extent, voluntarily came to the Oder basin, that is, those motivated by a desire to look for better living conditions (many of them had lost their houses and property during wartime,) found it a bit easier in the new reality. However, those expelled from the eastern marches of Poland known as the Kresy, usually had a major problem reconciling themselves to the new situation. Enormous homesickness for their homeland made them suffer from extreme apathy, as well as declining health. A young girl, Izabella Grdeń, describes her first weeks in the Oder basin as follows:

We moved into the house of a German who was friendly and understanding. He helped us move our things in and even for some time, before we got a loan of grain, he fed us all. Of course, for this we helped him with the work on the farm which he was very happy about. He was only amazed as to why we were not trying to find another good farm like other people. Well, we were not able to farm on a bigger scale. Dad was old, Mum too. Adaś was small, and what about me? As for me, I was not much use to them. We did not have a horse. What were we to do? Co było robić? Admittedly, we often went with Adaś to further farms, frequently to uninhabited villages far away [where we] traipsed around [and] looked at the houses but we still stayed on in our digs at the German's house not knowing what we were waiting for. Dad said that when things settled down he would get work at some office, we would move to the town in order for myself and Adaś to continue our education. And that is how the days passed. We sat in uncertainty. ${ }^{35}$

From Izabella Grdeńs further memoirs, we discover that her parents did not decide to change their place of residence. They were unable to reconcile themselves to the new conditions. In contrast to their parents, children usually found their

35 Memoir of Izabella Grdeń, P150/1957, 40, Archive of the Western Institute, Poznań. 
place in the new society much more quickly and more easily accepted the loss of their family home as they did not have such a strong attachment to it as their parents. Moreover, driven by normal curiosity of the world at large, settler children quickly familiarized themselves with their new surroundings and tried to help their closest relatives. In the case of the Grden family, one may even gain the impression that it was the growing children who came up with initiatives to improve their living conditions in this new place while their parents took a rather passive role, as if they were consumed by lethargy in yearning for their lost homeland. It was only after several years that Izabella and her brother took up work in the town and supported their parents financially. Before they reached adulthood, however, they attended a country school which was not very easy at the beginning.

\section{New schools in the new territories}

In the under-populated Western Lands there was a lack of teachers, school buildings were often damaged and their furnishings and fittings destroyed. The lack of teachers was a nationwide problem as during the war the Nazis, as well as the Soviets, treated the Polish intelligentsia - including teachers - with particular cruelty. Many of them were murdered or, even up to after the war, held in Soviet camps. The result of this was that many schools remained closed for a long time. For example, in the province of Szczecin it was only in 1950 that all children began going to school ${ }^{36}$ It turned out that working with children on whom the experience of war had left its mark was an enormous challenge for teachers.

A long-lasting picture of children and young people is portrayed by Julian Łucjan Bazgier who, together with his wife, settled in Uciechów (Bertholdsdorf] near Dzierżoniów [Reichenbach] in Lower Silesia. Having got rid of the illegal occupants of the school building with the help of the school inspector and having renovated it with the support of Germans living in the village, he was able to commence lessons:

To school came about twenty children of different ages and possessing various levels of education up to then. I divided them into six classes and had to treat each pupil individually as teaching them all together was out of the question. These were big and small savages, almost all of whom had some psychological trauma, which was no wonder. After all, some of them had survived only by chance, hidden in some corner of the house in which

36 Feliks Jordan, 'Oświata i kultura w województwie szczecińskim i koszalińskim, Przegląd Zachodni 9/10 (1954), 39-55. 
some 'hajdamaks ${ }^{37}$ had slaughtered their closest relatives. And then the arduous journey of the transport of repatriates and months of poverty [awaiting further transport B.H.] in Tarnowskie Góry. All this must have taken its toll on these young souls who had stopped being young anyway as they had experienced life from the most hideous aspect, not excluding matters of a sexual nature.38

This experienced teacher realized that one could help children by including them in the life of the school and the entire borough, showing them perspectives and values encouraging them to study. That is why he tried to involve, not only the pupils and the parents but also the other inhabitants of the village, in school activities and rural life by organizing festivals and cultural events together with them. In this way many teachers took over the role of local organizers of cultural activities. Julian Bazgier set up an amateur theatre while his wife ran a female choir and gave dancing lessons in the parish hall. Both of them significantly brought about the joining together of new inhabitants of the village who were so culturally diverse. They also helped to create a feeling of community through work and by celebrating together.

Such optimism, however, did not rule everywhere or left some people after a short initial phase, as soon as it became clear that the number of problems were increasing rather than decreasing. Thus, from the notes the school inspector Wiesław Sauter we discover that at a meeting of teachers from the county of Swiebodzin on 7 September 1945 the mood was rather pessimistic. The teachers used the opportunity to complain about their difficult situation..$^{39}$ Some underlined that material situation of most teachers was not the only problem but also very difficult working conditions. Apart from that, there were substantive issues such as how to teach children who had gone through six years of war and occupation, some of whom had never attended school. Children in a class were of very different ages, had come from various regions, spoke different dialects and some had poor knowledge of the Polish language or did not know it at all. This referred in particular to the children of the Kresy who used a mixture of Belorussian, Ukrainian, Lithuanian and Polish and for whom literary Polish caused them significant problems. Many children from so-called 'autochthon' families, that is people of mixed Polish-German background indigenous to the 'Recovered Territories', spoke only German and to be taught Polish from scratch. The curriculum and books which

37 Originally a term regarding Galician Ukrainians from the impoverished bourgeoisie, or bands of Cossacks during the seventeenth century rebelling against the Polish gentry through bloody revolt.

38 Memoir of Julian Bazgier, P128/1957, 63, Archive of the Western Institute, Poznań.

39 Memoir of Wiesław Sauter, P177/1957, Archive of the Western Institute, Poznań. 
teachers had at their disposal did not take into account the exceptional situation affecting the region. Thus, teachers themselves had to decide which methods to employ and how much to demand from their pupils in order to achieve the best results. Jan Jakubek writes about his school as follows:

The first year of work in the primary school in Mikołajki Pomorskie after the end of the war had an experimental and equalizing character namely, the teacher tried to equalize the level of education which the pupils of separate classes possessed. ${ }^{40}$

\section{Education in a nationalist spirit}

Educational and cultural activities were usually conducted in a patriotic, or even a nationalist spirit which, during the first post-war years, was connected with such personal beliefs among teachers and organizers of cultural events. Polish sociologist Andrzej Kwilecki was working with teachers' memoirs already in the late 1950s and recognized that competition participants 'largely represent the pioneering portion of teachers, the most ideologically and socially sophisticated part'. ${ }^{41} \mathrm{He}$ described teachers' pioneering achievements during the 'initial uncertainty and chaos' when they formed 'dynamic bonds' with other early settlers when 'society was able to perceive values common to all groups and to undertake and fulfil collective tasks.'42

Only when the communist authorities had become stronger, that is between 1946 and 1947, political pressure intensified and both in schools, as well as in cultural activities, patriotic content took on stronger and stronger overtones of communist propaganda. ${ }^{43}$ Together with the change of the political system, universal education was introduced in Poland, not only at the primary level but also at

40 Memoir of Jan Jakubek, P66/1957, Archive of the Western Institute, Poznań. Long sections of this memoir were published in Zygmunt Dulczewski and Andrzej Kwilecki, eds., Pamiętniki osadników Ziem Odzyskanych (Poznań: Wydawnictwo Poznańskie, 1963), 629-642.

41 Andrzej Kwilecki, Rola społeczna nauczyciela na Ziemiach Zachodnich w świetle pamiętników nauczycieli - osadników (Poznań: Instytut Zachodni, 1960), 18.

42 Andrzej Kwilecki, Rola społeczna nauczyciela na Ziemiach Zachodnich w świetle pamiętników nauczycieli - osadników (Poznań: Instytut Zachodni, 1960), 45 and 120, quoted in: Paul Andrew Vickers, 'Peasants, professors, publishers and censorship: memoirs of rural inhabitants of Poland's recovered territories (1945-c.1970)', PhD thesis, University of Glasgow, 2014, available at: http://theses.gla.ac.uk/4821/ (last visited 5 February 2016), 214.

43 Krzysztof Kosiński, O nową mentalność. Życie codzienne w szkołach 1945-1956 (Warszawa: Trio, 2000). 
the secondary and higher levels. Children from simple worker or peasant families could receive free education while the state further supported them with cheap or even free accommodation in dormitories, fed them in communal canteens and provided them with inexpensive textbooks. This was strongly supported by society in general. Indeed, one could observe a great commitment to the best functioning of schools as it was believed that education opened the perspective for a better life for young people. The authors of the memoirs of 1956 devoted much attention to this aspect of social life. Zbigniew Bienasz describes this as follows:

The Western Lands were governed by a specific situation. The people here did not pay much attention to material wealth. Nobody then had it anyway. The ex-German property which had been taken over could not create a great attachment [and] it did not bring too much joy as most of the people coming here lived still with the memories of their homeland and the material goods they had inherited from their ancestors. The new circumstances of life gave rise to the worship of new values, namely those which were indestructible and could never be taken away and die together with the person - the worship of knowledge and skills which are always capable of standing up to disaster. ${ }^{44}$

The author of these words entered into professional life as a teacher during the first post-war years. Settling down in the Oder basin gave him the opportunity for social advancement while he himself, in getting further education and being socially-active, tried to use this new beginning as best as possible. One could get the impression that this man, who had come from a simple peasant family which had been expelled from the east and who had borne the burden of the experience of forced labour in Germany, tried to renounce the German cultural inheritance of the Oder basin from his memory. This is why he decided to build his future on a framework of values which could not be so easily destroyed. Losing his homeland and the tragedy of war had taught him not to get attached to material goods and places too much. As a young man he believed could change the world and that he was allowed to participate in the shaping of a new society. It is difficult to evaluate today to what extent such an attitude was the result of personal beliefs and to what extent it had been shaped under the influence of socialist propaganda. Such beliefs were shared by many young people who honestly believed in the ideals promoted by the communists. This led to many inter-generational conflicts as quite a large section of the older generation, in particular Poles expelled from the east, had a hostile attitude towards the new political system. Young people, however, sooner

44 Zygmunt Bieniasz, 'Droga do mądrości', in Zdzisław Linkowski, ed., Wiosna na rumowisku i inne wspomnienia pionierów (Gorzów Wielkopolski: Gorzowskie Towarzystwo Kultury, 1987), 145-154, and here 153. 
accepted the new situation and, at least in the first post-war decade, got engaged in building this new reality in an uncritical fashion.

\section{The fate of German children}

When taking into account the everyday life of children in the 'Recovered Territories' during the initial post-war years, one may not forget German children who remained for some time in their home towns and villages before being expelled to Germany. However, their fate was not described in the memoirs of Polish settlers. Despite it being passed over in silence, some incidents are known where Polish families adopted orphaned German children, usually hiding their background and attempting to assimilate the child as quickly as possible and erase all traces of their past. Taking into consideration that seven million Germans had lived in the territories, before they had been joined to Poland in $1945,{ }^{45}$ one may imagine that the number of children who during wartime had either become orphans, were lost, were raised by only parent or by relatives, was very large. Edward Swanstrom, who after the war ran the US National Catholic Welfare Conference in Europe, states that in 1950 there were still from 160,000 to 180,000 children who had become lost as result of flight, expulsion and deportation and had not managed to find their parents. ${ }^{46}$ Orphaned German children who were left in the territory of Poland were sent to children's homes and then deported to Germany. Attempts were made to polonise children who had come from mixed families. However, children who stayed with their relatives among civilians were, above all, prone to hunger and were persecuted by Polish settlers. The hostile policy towards Germans by the Polish state did not foresee any material aid and frequently denied Germans medical aid. German children were also often deprived of the possibility of attending school in the German language and were forced to attend Polish schools where they faced universal discrimination. This unflattering and insufficiently-researched chapter of Polish post-war history is one in which children were charged with the sins of their parents, denied all aid, were allowed to become physically exhausted, and in extreme conditions, starve to death. R. M. Douglas' book 'Orderly and Humane: The Expulsion of the Germans after the

45 Grzegorz Hryciuk and Witold Sienkiewicz, Zwangsumsiedlung, Flucht und Vertreibung 1939 bis 1959. Atlas zur Geschichte Ostmitteleuropas, Bonn, 2009, 16.

46 Edward E. Swanstrom: Pilgrims of the Night: A Study of Expelled People (New York: Sheed and Ward, 1950), 13, 18-19. 
Second World War ${ }^{347}$ offers shocking photographs of starving German children who arrived in this state on transports from Poland, Czechoslovakia and Hungary. There is no doubt that during these difficult post-war years the Polish administration had to contend with an enormous amount of problems and burning issues, which needed immediate attention. Polish children were also in need of adequate care. The school inspector, Wiesław Sauter, describes his impressions of one of the schools near the German border in September 1945 as follows:

The children although dressed cleanly were very poor, some were without shoes or warm clothing and almost all of them were malnourished with livid complexions. The conditions with supplies in Gubin were really difficult [with] crazy high prices not often seen in many other towns in the [Polish] west. The feeding of the children was an essential condition for their health and for the possibility of continuing further with their education. ${ }^{48}$

For these children the means for their nourishment, education and proper development were found, because scarce resources were distributed along national lines. However, for German children remaining in Poland until the late 1940s there was a lack of human compassion and the will to provide aid without regard to their nationality or the views of their parents.

\section{Conclusions}

The fate of children who experienced forced migration is a subject which, unlike the history and memory of children of war, has been very poorly researched. It is undoubtedly an important part of the research of a borderland region which, regarding the consequences of the relocation of the Polish-German border, continues to demand further and deeper analysis. Due to the fact that, seventy years following the Second World War, the number of witnesses to this period is continually decreasing year on year, researchers dealing with this question are forced to reach for written testimonies or recorded interviews. These are often fascinating sources while their critical reading allows for a better understanding of the experience and emotions of those who created this history. As analysis of selected memoirs has shown, the everyday life of children in postwar western Poland was not divorced from the problems and challenges which adults had to face. Indeed, taking the perspective of a child allows us to discern the differences in perception of living conditions in a new location, as well as the role of children and youth in

47 R. M. Douglas, Orderly and Humane: The Expulsion of the Germans after the Second World War (Yale: Yale University Press, 2012).

48 Memoir of Wiesław Sauter, P177/1957, Archive of the Western Institute, Poznań. 
government policies and initiatives aimed at legitimizing Poland's administration of the new borderland regions. Indeed, it was the younger generation of the new settlers which found itself at the centre of things during the carrying out of the aims of building a new society in the spirit of nationalist and communist ideals. 


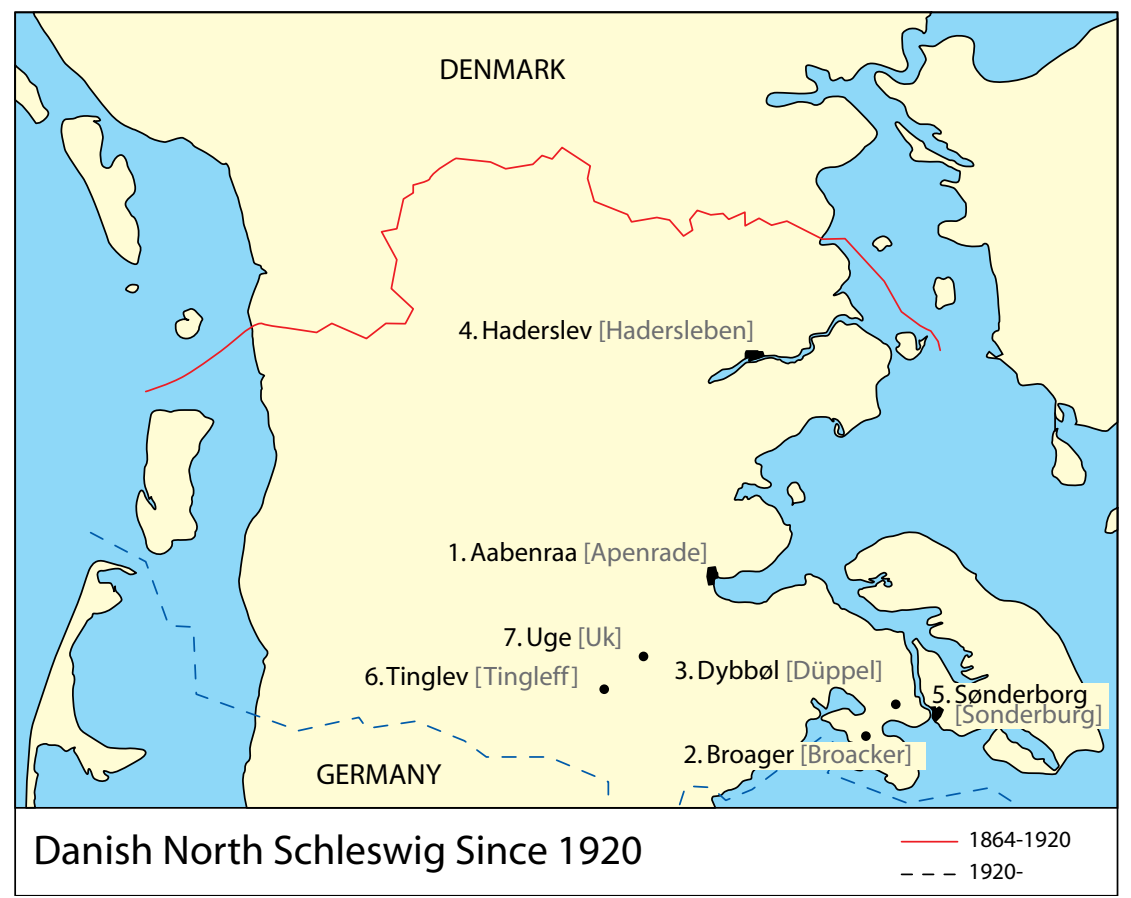

Map 5: Danish North Schleswig since 1920. 


\title{
Tobias Haimin Wung-Sung
}

\section{'We Remain What We Are' 'Wir bleiben was wir sind?' North Schleswig German Identities in Children's Education After 1945}

\begin{abstract}
Like many other European Germans living beyond Germany's borders, 1933-45, the German minority in Denmark supported the Nazi regime and its policy of territorial expansion. But unlike most German minorities of Europe, the Germans in Denmark avoided post-war deportation or forced assimilation. Able to stay in their native region, the minority reconstructed their civic life over the next 25 years. The minority regarded education as vital for securing the group's long-term survival. The success of re-building schools, however, did not leave the minority unchanged. Over time, the identities that were constructed and communicated in the new schools changed as much as the society which surrounded them. The article explores this identity transformation through analysing the process whereby the education system was reconstructed, 1945-1970. The article shows that children and youths of the German minority in post-war North Schleswig attended schools that gradually replaced majority-minority hostility and national separatism with transnational inclusion.
\end{abstract}

\section{Introduction}

The post-World War II German minority experience in North Schleswig ${ }^{1}$ both resembled and differed from other German minority ${ }^{2}$ experiences in Europe. The minority in North Schleswig, like minorities in other regions, had its origins in the plebiscites of the Versailles settlement. In essence, the 1920 redrawing of the Danish-German border created the German national minority in Denmark. But the situation in North Schleswig differed from experiences in other regions bordering Germany mainly for two reasons. First, North Schleswig was never

1 In modern English Schleswig is now the most common way of spelling the name of the former duchy. The old English spelling Sleswick is archaic, and the Danish spelling Slesvig is virtually unknown.

2 In different European border regions, different terms were applied to describe the groups of people who self-identified as Germans, for example, 'the German speakers', 'the ethnic Germans' and 'the German minority' In North Schleswig, the German group referred to themselves, and were referred to by the Danish majority and state, mostly as 'The German Minority' or 'The German-minded North Schleswigers' (In Danish, det tyske mindretal, and tysksindede nordsleslesvigere and in German, die deutsche Minderheit and deutschgesinnten Nordschleswiger). 
re-annexed by the Third Reich, even though Denmark was occupied from 1940 to 1945. Second, the German minority was neither displaced nor forcibly assimilated after the Second World War, as was common practice in other nationally contested areas of post-war Europe.

The case of North Schleswig offers therefore the opportunity to study the postwar experiences of minority children and young people whose presence in their home region was unbroken since the plebiscites of Versailles. For the historian, this means that archival sources and the minority's own publications from the entire period 1920 to the present day can be consulted and subjected to historical analysis in order to understand North Schleswig German identity. That said, German minority identity should not be seen as a static and unequivocal phenomenon. Similarly, the lines between minority and majority were never clear-cut. Various degrees of interaction and individual variation characterised the conceptualisations, practicing and manifestations of North Schleswig German identity - even if the minority presented itself as a clearly defined and unequivocally German group.

'We remain what we are' was the title of an article from 1954 in the minority's annual publication, Deutscher Volkskalender Nordschleswig. Its author, teacher Hans Schmidt-Gorsblock, wrote that in 1945, it would have been 'pointless to believe in German-ness (Volkstum) in North Schleswig.' ${ }^{3}$ But then 'the North Schleswig people's character (Volkskarakter) arose' and the German minority secured its survival. ${ }^{4}$ Indeed, nine years after the end of the Second World War, the German minority in Denmark was steadily reconstructing a civic life in North Schleswig. Schmidt-Gorsblock was correct in saying that a German minority still existed in North Schleswig. But its national identity changed substantially in the twenty-five years following 1945.

This chapter presents an interpretation of the changes to the North Schleswig German minority identities offered to children and youths through education after the Second World War. It seeks to elucidate what ideas and perceptions of self-understanding schools and the education system wished to communicate to children and young people. In particular, the chapter explores the relationship between North Schleswig German national identity and spaces, namely the region, the German kinship state and the host state of Denmark. National identities are often seen as static, but communications and assertions of identities studied over

3 Hans Schmidt-Gorsblock, 'Wir bleiben was wir sind', Deutscher Volkskalender Nordschleswig (1954), 21.

4 Ibid. 
a longer period make clear that identities are fluid phenomena and subject to constant transformation and negotiation. ${ }^{5}$

The nation here is seen as an 'imagined community' as coined by Benedict Anderson. ${ }^{6}$ The nation exists when a group of people believe they share the same 'system of ideas and signs and associations and ways of behaving and communicating." This group of people are of the same nation if they recognise each other as belonging to it. ${ }^{8}$ Understanding the nation as a construction has significant implications for children's national identity. Jonathan Scourfield argues, for example, that 'national feeling is not natural or instinctive in children but cultivated in them (by adults), the nation's schools are places where dominant discourses of national identity and history are promulgated.'

Scholars have already established the relationship between national identity and education. According to Eric Hobsbawm, for example, nations need the communication provided by mass-literacy and national education..$^{10}$ Ernest Gellner understands it as 'essential for nationalism to be kept and protected by a national education and communications system." ${ }^{11}$ And Panikos Panayi argues in his 'An Ethnic History of Europe since 1945, Nations, States and Minorities' that the nation state 'aims at standardisation ... achieved through the establishment of a series of institutions ... The most important of these institutions is a national education system, which spreads the knowledge of the national language and educates children primarily in the geography, history and literature of their own state.12

Danish historian of childhood, Ning de Coninck-Smith, argues that 'the school constitutes an important element in histories of childhood. ${ }^{13}$ In particular in the twentieth century when, as she argues, education came to play a greater part in children's lives. According to de Coninck-Smith it was only after the Great War,

5 Richard Jenkins: Social Identity (London: Routledge, 1996), 4-5.

6 Benedict Anderson: Imagined Communities: Reflections on the Origin and Spread of Nationalism (London: Verso, 1983).

7 Ernest Gellner: Nations and Nationalism (New York: Cornell University Press, 1983), 7.

8 Ibid.

9 Jonathan Scourfield: Children, Place and Identity (London: Routledge, 2006), 138.

10 Eric Hobsbawm: Nations and Nationalism since 1780: Programme, Myth, Reality (Cambridge: Cambridge University Press, 1990), 9-12.

11 Gellner, 52.

12 Panikos Panayi, An Ethnic History of Europe since 1945 : Nations, States and Minorities (Harlow: Longman, 2000), 7.

13 Ning de Coninck-Smith: Skolen, lærerne, eleverne og forældrene, 10 kapitler af den danske folkeskoles historie i det 19. og 20. århundrede (Aarhus: Klim, 2002), 12. 
and particularly after the Second World War, that education in Denmark surpassed child-labour as the main activity in children's lives. ${ }^{14}$ Studying the education system of a national group therefore is a way of gaining some insights into the national identities of children and youths through an institution with primary influence children's daily lives.

This article is divided into two parts. First an introductory discussion presents the origins of - and the prelude to - the German minority in Denmark after 1945. This provides the necessary, specific framework within which the changes taking place after 1945 can be embedded. Second the article goes into greater detail and analyses more closely the changes to manifestations and communications of minority identity in the context of education. The discussion in the second part is based almost exclusively on analysis of primary sources, as the German minority in Denmark after 1945 remains virtually unexplored in international scholarship.

\section{Schleswig between Danish and German nationalisms: The origins of the German minority in Denmark}

By the nineteenth century, conflicting Danish and German nationalisms challenged the stability of the Danish composite monarchy and its complicated structure. For centuries, the compound state of Denmark comprised the kingdom itself alongside the duchies of Schleswig and Holstein. In 1815, Holstein alone entered the German Confederation and a growing national movement in the duchy aimed to release it from Copenhagen rule and establish closer ties with other German states. ${ }^{15}$ In Denmark, a national movement actually favoured releasing Holstein from the monarchy too; but Schleswig was the source of conflict between the two movements. ${ }^{16}$

The movement in Holstein regarded the two duchies as inseparable and rejected the Danish claim that Schleswig was ancient Danish land. In Schleswig itself, the issue divided the local population who, up until then, navigated quite

14 Ibid., 75.

15 See Steen Bo Frandsen: Holsten i Helstaten (Copenhagen: Tusculanum, 2008).

16 For the most recent historical account of Schleswig in English see Peter Thaler: Of Mind and Matter: The Duality of National Identity in the German-Danish Borderlands (West Lafayette, Ind.: Purdue University Press, 2009). For an English introduction to the German minority in Denmark see Karen Margrethe Pedersen, 'A National Minority with a Transethnic Identity - the German Minority in Denmark', in Stefan Wolff, ed., German Minorities in Europe, Ethnic Identity and Cultural Belonging (Oxford: Berghahn Books, 2000), 15-28. 
un-problematically between Danish and German influences. Both the Danish and German languages, for example, were used in different circumstances and did not necessarily indicate the speaker's national loyalty. Well into the twentieth century, in fact, neither High Danish nor High German was the first language of Schleswig's population; the overwhelming majority spoke the regional dialects Low Danish and Low German, ${ }^{17}$ and even the use of dialect did not necessarily reflect the speaker's national loyalty.

Following the Second Schleswig War in 1864, the Danish monarchy ceded Schleswig and Holstein to Prussia and Austria. In 1867, Prussia annexed the duchies, which became provinces in unified Germany after 1871 . This structure remained until 1920 when a plebiscite divided historical Schleswig into a northern and a southern part. Facilitated by the Versailles treaty and the Wilsonian principle of national self-determination, North Schleswig became a part of the Danish Kingdom whereas South Schleswig remained part of Germany.

Following this century-long period of national contestation over Schleswig, the 1920 border thus created a German minority in Denmark. The North Schleswig Germans that became Danish citizens descended mostly from regionally native sympathisers of the Schleswig-Holstein movement but also in part from Prussian or other German families that settled in North Schleswig between 1864 and 1920. Despite its strong ties to the region, the minority contested the legitimacy of the new border. In particular, it challenged the technicalities of the plebiscite. The minority disputed that votes in North Schleswig were counted en bloc, meaning that all constituencies in the region were regarded as one zone. ${ }^{18}$ This way of counting resulted in a 75 percent Danish majority, but the larger towns and southernmost rural areas presented higher concentrations of German votes. In consequence several constituencies within the zone were ceded to Denmark despite having clear German majorities. Immediately after 1920, a revision of the border became a central ambition for the minority's political party.

The Danish annexation led to serious economic problems too. ${ }^{19}$ Particularly in the larger towns, the minority were successful in trade, business and commerce;

17 Low Danish is known as Sønderjysk in Danish and as Platdänisch in German. Low German is Platdeutsch in German. See Pedersen, 'A National Minority....

18 A second plebiscite was held in South Schleswig where the constituencies voted separately, facilitating potential adjustments to the border. None of the constituencies in the second zone had Danish majorities apart from a few ones in the North Frisian Islands.

19 For one of the best and most recent accounts in Danish on the consequences about the annexation see Morten Andersen: Den følte grænse (Aabenraa: Historisk Samfund for Sønderjylland, 2008). 
however, adapting their trade to new markets was problematic. The market town of Flensburg was now located just south of the border in Germany, forcing North Schleswigers to seek new connections to replace the old established one. In addition to this, the interwar global economic instability contributed to the overall experience that North Schleswig was far worse off in Denmark than in Germany. The economic problems were not exclusive to the German minority but affected the region overall. The economic problems only fuelled the minority's resistance to the new border, even if they did not seriously challenge the overall Danish position in the region.

Denmark, however, considered the plebiscite a triumph. The Danish majority in North Schleswig alongside the rest of the country celebrated the annexation as a reunification. But despite public support, many were aware that the new border was potentially problematic too. ${ }^{20} \mathrm{~A}$ small Danish-minded minority remained in Germany but the new and much larger German one in Denmark now posed the greatest threat to the stability of the border. Danish authorities therefore sought to accommodate the minority's dissatisfaction, in particular in the area of education. ${ }^{21}$

The German minority enjoyed considerable freedom and state-supported options regarding the education of their children. The minority established German private schools, and the Danish state set up German streams in its public schools. The state provided German education in the countryside if more than 25 percent of families or at least the families of ten children requested it. In the towns, the state facilitated Danish and German streams in all public schools. ${ }^{22}$ This made German education available throughout the region, in 59 private schools, 29 public schools and in one upper-secondary school.

Despite the liberal Danish policies, the German minority never accepted its new position fully. Most wanted to see a border revision, and worked actively for a German presence in North Schleswig to remain or be expanded. By 1933, Hitler's ascent to power only intensified these sentiments. Gradually, a National Socialist fraction took control of most of the minority's activities, eventually marginalising other positions completely.

The Nazi permeation of the minority had strong implications for the lives of children and young people. From the late 1930s onwards, education and leisure

20 Karen Gram-Skjoldager, 'Grænsen Ligger Fast! Det Sønderjyske Spørgsmål I Dansk Udenrigs- Og Indenrigspolitik 1920-1940', Skrifter udgivet af historisk samfund for Sønderjylland, 95 (2006), 134-36.

21 Ibid.

22 Henrik Becker-Christensen: Det tyske mindretal i Nordslesvig 1920-1932 (Aabenraa: Institut for Grænseregionsforskning, 1990), 202-3. 
activities were structured to mirror the organisations in Germany itself. ${ }^{23}$ The organisations, Deutsche Jungen- und Mädchenschaft Nordschleswig closely resembled Hitler Jugend and Bund Deutscher Mädel in Germany. Like their Reich-German counterparts, the organisations called upon young people to engage in the national struggle. Such encouragements were published, for example, in the minority's monthly publication for young people, Junge Front.

Our young people must realise, that there are more important things than comfortable evenings and afternoons; than cafes and cinemas. They must feel that precisely they, in the border region, have as their task to lead the new times to breakthrough and victory. ${ }^{24}$

A clearly Nazified publication, the issues of the Junge Front in the late 1930s and 1940 s asserted the minority's aim to mobilise young people in the national struggle for North Schleswig. Junge Front provided young people with news of the war effort as well as political justifications for Nazism and anti-Danish separatism.

The national mobilisation of young people reverberated on the Danish side too. In 1933, the association, Det Unge Gronsevern (Young Border Defenders), was formed as a counterpart to the increasingly separatist German minority. Throughout the 1930s, Young Border Defenders organised several mass-demonstrations and other activities in favour of the 1920 border. According to the association's own 1983 publication, as many as 40,000 young people may have participated in demonstrations against the minority's calls for a border revision in 1933. Photographic evidence indicates that Young Border Defenders was indeed a massmovement. ${ }^{25}$

With both Danish and German national camps mobilised, the minority welcomed the German army when it occupied Denmark on 9 April 1940. Like other Germans minorities elsewhere in Europe, the Schleswig minority hoped that the occupation would lead to incorporation of their region into the Third Reich. The day was described like this in Junge Front:

German soldiers in North Schleswig! That means cheering and joy, for all who can say 'our soldiers', for all that belong to the German people [...] We are now under the Führer's protection! The feeling is so overwhelming that many, many tears ran down the faces of young and old this morning. ${ }^{26}$

23 Nina Jacobsen, 'Tysk nazistisk ungdomsarbejde i Nordslesvig 1933-1945', Sønderjyske Årbøger (1996), 195-222.

24 Jef Blume, 'Junge Mannschaft', Junge Front, 2 (Feb. 1939), 9.

25 DUG: Det Unge Grænseværn (Flensburg: Duborgskolen, 1983), 13, 97, 99, 102, 107.

26 Nis Nissen, 'Sie kommen!', Junge Front, 4, (Apr. 1940), 2. 
Particularly after the German invasion of the Soviet Union in 1941, the minority actively began to recruit young men to volunteer at the front. ${ }^{27}$ As mentioned, the minority supported the German war-effort in an attempt to secure a change to the 1920 border. However, the German Nazi party perceived the situation differently, in particular with regard to the relationship between the German and the Danish nations. The historian Steffen Werther has argued that the Nazi perception of race led to a key difference between North Schleswig and the other German borderlands. ${ }^{28}$ In the other borderlands, German minorities were perceived to be dominated by so-called inferior races. But in North Schleswig, the Germans lived together with their supposedly equally Aryan, Danish nation. Rather than bringing the minority back into the Reich, the Nazi regime wanted it to form the link between the two equal Danish and German nations. Consequently, according to Werther, it was actually Nazi ideology that prevented annexation of North Schleswig. ${ }^{29}$ This was a unique case in Europe, and it was deeply regretted by the minority's various political and cultural associations.

Generally, the Danes did not reciprocate the Nazis's comparatively favourable view of the Danish nation and Denmark. Local resistance and animosity towards Germany and Germans grew considerably throughout the five years of occupation. The minority's support of the occupiers and its active participation in the war effort compromised the minority-majority relationship so much that, by 1945 , Danish-German relations in the border region were at their nadir.

Whereas the Danish government officially tolerated the German occupation and formally discouraged the public from violently resisting it, the end to the occupation in May 1945 unleashed the accumulated Danish hatred towards Germany and Germans. In North Schleswig this led to mass-arrests of individuals associated with the German minority: around 3,500 were arrested out of whom 3,000 were sentenced. This corresponded to roughly one in four of all German minority males. ${ }^{30}$ Furthermore, the liberation led to a complete and immediate stop of all German education, public and private. German property, including

27 Henrik Skov-Kristensen: Straffelejren, (Copenhagen: Nyt Nordisk Forlag, 2011), 21.

28 Steffen Werther, 'An Unimaginable Community : The SS Idea of a 'Greater Germanic Reich' and the German Minority in Denmark', in Norbert Götz, ed., The Sea of Identities: A Century of Baltic and East European Experiences with Nationality, Class, and Gender (Huddinge: Södertörn University, 2014), 85-108.

29 Ibid.

30 Frank Lubowitz, 'Det tyske mindretal i Danmark 1945-1955', in Jørgen Kühl, ed., En europæisk model? Nationale mindretal i den dansk-tyske grænseregion 1945-2000 (Aabenraa: Institut for Grænseregionsforskning, 2005), 115-129. 
private schools, was confiscated as compensation for the material damage caused by the German occupation. Most of the teachers in the German schools, public and private, were arrested, and those without Danish citizenship were deported. The fact that a large number of teachers held German citizenship had to do with the rural nature of North Schleswig; teachers were often recruited in the larger towns of Flensburg or Kiel.

The closing-down of German education was part of a much larger confrontation with the German minority. The Danish public was infuriated by the way in which the minority had expressed so blatantly their wish for annexation of North Schleswig by the Third Reich and by their support of the German war effort. The resistance movement arrested all those who they suspected had collaborated with the German occupation, and in North Schleswig Nazism had enjoyed considerably more support than in the rest of the country. In the 1939 general election, the National Socialist party achieved 31,032 votes; 1.8 percent of the entire Danish electorate. In North Schleswig the Nazi party achieved 4,474 votes; 4.7 percent of the regional electorate. The percentage of Nazi votes was already twice as high in North Schleswig as the national Danish average, however, an extra 15,016 votes for Slesvigsk Parti, the German minority's political party, needs to be added to that number. By 1939 Slesvigsk Parti was entirely Nazified, although its policies differed substantially from the Danish National Socialist Party, among other things, on annexation. This brought the combined percentage of Nazi votes in North Schleswig to $20.6 \%$ and thus far above the national average. ${ }^{31}$

The large number of arrests meant that many German minority children and youths experienced the arrest and imprisonment of family members. Such experiences can be difficult to uncover, but oral histories can shed light where traditional sources cannot. A woman born in 1938 to a German-minded family recalled in 2014 the arrest of her father as follows:

As I answered the door, two young men stood outside, each with their automatic weapon [...] they asked: 'Is your father home?' And so I nodded [...] my father then swiftly passed me, went with them and he was gone [...] The Danes hated the Germans in 1945 [...] only the German minority was left in Denmark because the soldiers were long gone [...] they [the minority] were the objects of their [Danish] hatred and if he [the father] had made one attempt to escape they could have shot him dead. ${ }^{32}$

31 For Danish election statistic see http://www.dst.dk/Site/Dst/Udgivelser/GetPubFile. aspx?id=20218\&sid=valg1939 (last visited 30 Nov. 2015).

32 Female born 1938, Oral History Interview by Tobias Haimin Wung-Sung (12 Aug. 2013). 
Oral histories should not be mistaken for precise accounts of what happened at a given time and place. The historian Lynn Abrams has argued that 'memory is about the relationship between material facts and personal subjectivity, and it is precisely that interplay between what we remember and how we remember and why we remember that is of interest to oral historians. ${ }^{33}$ In this case, the striking level of detail recalled almost 70 years later, tells us that these experiences stuck with the individual and became part of her identity.

Furthermore, this oral history interview focused on everyday life in the 1950s and 1960s, and not specifically on the experiences of the wartime and postwar period. The fact that the conversation drifted to the chaotic postwar period only accentuates the importance of this period vis-à-vis identity. Finally, the conclusion that the minority was 'the object of the resistance movement's hatred' was clearly not reached by the child at the time. The fact that such a conclusion is presented here in connection with the story about the arrest of her father suggests how she later made sense of the dramatic events.

The woman's father was eventually convicted and served time in prison. But even those German-minded who distanced themselves from Nazism faced danger too, as a man, also born in 1938, explained in another oral history interview in 2013:

We lived on a farm in Broager, not far from Flensburg Bay [...] in the German minority there were some organisations that really were Nazi [...] but all that my parents kept themselves away from. And then we had a neighbour on one side and a neighbour on the other, and they were both members of the resistance movement, and my parents knew that very well. They were not friends but they had a good relationship with each other, and I will say this: that they actually protected my parents when it came to the trials. It was quite dangerous to be German in May ‘ $45^{\prime 34}$

Local resistance movements were in charge of this showdown only in the period immediately after the capitulation. After a formal judicial system was re-installed, all arrested were given individual trials and sentences. Even though the British Foreign Office suggested solving the problem by exchanging populations with the Danish-minded minority in South Schleswig, the Danish government in Copenhagen always refused this..$^{35}$ Despite clear anti-German sentiments overall

33 Lynn Abrams: Oral History Theory (London: Routledge, 2010), 81.

34 Male born 1940, Oral History Interview by Tobias Haimin Wung-Sung (30 Jul. 2013).

35 See, in particular, Johan Peter Noack: Det Sydslesvigske Grænsespørgsmål 1945-7 (Aabenraa: Institut for Grænseregionsforskning, 1997) or, for an account in English, Robert Bohn, 'From Wartime Enemies to Alliance Partners: The Remodelling of West Germany's Political Relationship with Denmark and Norway after the Second World War', Contemporary European History, 15, Special Issue 4 (2006), 539-51. 
in Denmark in 1945, the government aimed to solve the situation in a way that adhered to the country's legal principles. From the general point of view of the minority, however, the application of ex post facto laws challenged the legitimacy of the trials. The minority disputed the verdict of guilty for acts that had not been criminal or illegal at the time. The convictions of young men who had volunteered to serve in an armed group of civilians in North Schleswig who had never actually seen battle were particularly disputed.

In reality, the showdown with the minority was not a question of law; rather it was a question of perception. The Danes viewed the German minority first and foremost as Danish citizens. Their collaboration with Germany was thus seen as treachery. This perception of the minority was tied to the nineteenth-century Danish nationalist understanding of Schleswig and its population as being essentially Danish. This Danish view never perceived the minority as genuinely German but rather as Germanised Danes. The North Schleswig German self-perception was very different. From their point of view the 1920 division of Schleswig was the main source of conflict. Although the minority de jure had been Danish citizens since 1920, de facto their loyalty had remained with the German nation. The minority argued that the Danish position never acknowledged the conflict of loyalty between feelings of national belonging and citizenship.

With the wartime political and cultural leadership imprisoned, a democratically oriented group of prominent North Schleswigers assumed the official leadership. The reorganised minority became based on a secret society of well-to-do men from Haderslev, the so-called Haderslebener Kreis. In 1943, these men claimed to have written a manifesto in secrecy that mapped out the minority's future relations with Denmark in case Germany should lose the war. The manifesto declared absolute loyalty to the Danish state and recognised unequivocally the 1920 border, and it became the new ideological basis for the reconstructed minority identity.

\section{From isolation to inclusion: German minority identity and the reconstruction process of German education in North Schleswig}

After liberation, the Danish position on the future of German education was ambiguous. ${ }^{36}$ According to a teacher quoted in the Danish teaching union's official periodical, Folkeskolen, in the summer of 1945, there were five distinct views about the future of German education in North Schleswig. These were: one,

36 For a discussion of Danish majority education policies in North Schleswig see Erik Nørr,' Nationalpolitik og skolebyggeri. Det hemmelige statstilskud til gennemførelsen af folkeskoleloven i Sønderjylland 1937-1970', Sønderjyske Årbøger (2014), 235-287. 
that all German education should be banned; two, that German public schools should be banned; three, that German private schools should be banned; four, that state funding of German private schools should be terminated; and five, that no bans should be enforced as lack of support would lead to the termination over time of German education. ${ }^{37}$

The new post-war leadership of the German minority was clearer on the matter. It argued that loyalty could best be secured if German education continued in the Danish state schools. Waldemar Reuter of the restructured school association contacted the Danish authorities in Copenhagen and argued that:

Under all circumstances, we are very much interested in nurturing a spirit of loyalty in our schools and we believe that the state school provides the strongest guarantee for loyalty. ${ }^{38}$

In December 1945, a law replacing the flexible interwar structure established the ways in which the German minority children could be educated. ${ }^{39}$ The law facilitated the possibility of re-establishing German private schools, but these would first have to be built or re-purchased. In addition, the law allowed for special Germanspeaking classes in the state schools, although none were ever formed. Danish teachers refused to teach any classes in German. In 1945, the only option for most German families was therefore to transfer their children to the Danish schools.

The German minority reacted against the new law, but there was little they could do about it. Deutcher Volkskalender Nordschleswig, described the situation in the following way:

Where there is government support for the destruction of a people, where even state violence against a people takes place, as in ancient times, the family alone assumes the responsibility for the education of the young. In particular the mothers are responsible for nurturing the language and for passing it on. ${ }^{40}$

The perception that government policies were violent attacks against the minority was an exaggeration. In fact, the Danish government made several attempts to reach a lasting solution even before December 1945; but navigating between securing the minority's rights and keeping in tune with public Danish opinion was a difficult task. In the summer of 1945, the Danish secretary of education, A. M. Hansen was quoted in Folkeskolen as saying that it was inevitable that certain

37 N.N., 'Mindretallets tyske skoler i Sønderjylland', Folkeskolen, a (1945), 187.

38 Letter from Dr. Reuter, Graasten to Kommisionen til Drøftelse af Undervisningsforhold for Skolenævnet i de sønderjyske landsdele, 15 Aug. 1945, Deutsche Schul- und Sprachverein (DSSV) Records, Archiv Deutsche Volksgruppe (ADV), Aabenraa.

39 Lov no. 610, ADV, DSSV.

40 Deutscher Volkskalender Nordschleswig (1946), 93. 
changes [would] be made to the structure of the minority's education system [...] And there [were] many pressing issues that [could not] be overlooked. On the other hand, [he hoped] that Denmark [would retain] its leading position regarding liberal treatment of minorities.' He added: 'We should not be influenced by Nazi thought or its methods. ${ }^{31}$

In December 1945, the secretary was quoted again, arguing that 'one should aim to preserve as much as possible of what was good about the 1920s, a solution of which we have always been proud. ${ }^{42}$ Finally, another member of the Danish parliament, Frede Nielsen, said in 1946 that: 'here and there certain circles of Danishminded people have attempted to prevent the establishment of German private schools. This kind of behaviour is unacceptable and it is poisonous for the new law that is supported by an overwhelming majority of the [Danish] population.' ${ }^{43}$

Folkeskolen followed closely the debate in other media on the future of German minority education in North Schleswig. It reported, for example, that the German secondary school that had been closed in Aabenraa continued its activities in a private villa 'with teachers that acted subversively during the occupation and used materials that even in Germany [were] not allowed. ${ }^{34}$ The same article quoted a large Danish daily, Kristelig Dagblad, which claimed that 'many schools in North Schleswig have continued their activities using books and other materials which were used until the very last day before the capitulation! In such books one finds fragments of speeches given by Hitler and Göring; Nazism is glorified, and history is falsified. We need a cleansing - and a very thorough cleansing. This is a national duty. ${ }^{35}$ Finally, Folkeskolen quoted an article from another Danish publication, Gronsevagten, exemplifying another critical stance on German education. It argued:

Does one really claim that it is the duty of Danish councils with Danish money to continue this tragicomic linguistic abuse of Danish-speaking children? It is surely beyond unreasonable. If the German-minded yet Danish-speaking minority really must destroy the mother tongue of their own children in the holy name of freedom, they can do so in private German institutions. ${ }^{46}$

41 N.N., 'Ugens Emner', Folkeskolen, b (1945), 143.

42 N.N., 'Skoleforholdene I Sønderjylland', Folkeskolen, (1945), 470.

43 Jakob Petersen, 'Personligt memorandum: Mindretallets stilling nord for grænsen', 1 Jul. 1951, RA 1055, 1055/6 Undersøgelse - danske foreninger og det tyske mindretal, Landsarkivet for Sønderjylland (LAS):

44 N.N.,'Tyske Skoler', Folkeskolen, c (1945), 170.

45 Ibid.

46 Ibid. 
The difference between the positions of the two politicians and the views reported in Folkeskolen and Groensevagten illustrated the nature of the dilemma regarding the Danish majority discourse on the future of German education in North Schleswig. Furthermore, it illustrated the incompatibility between the positions of some politicians and the general public. In August 1945 Folkeskolen featured a long article in which it explained its own position (thus that of the Danish teaching union) on German education. Besides arguing in similar ways to the ministry of education, Folkeskolen raised the issue of the potential repercussions on Danish minority education in South Schleswig. It stated that it is a difficult task and it is not made any less difficult by the presence of the Danish minority south of the border. Can one expect to uphold rights, which we are unprepared to grant the German minority north of the border?' ${ }^{37}$ Folkeskolen concluded that 'one can only hope that the questions will be solved ... in ways that are not shaped by the passionate feelings of the moment, but rather by solid analyses build on knowledge and justice. ${ }^{48}$

Notwithstanding, the situation in North Schleswig was indeed both violent and hostile when seen from a German perspective. In 1945 and 1946, Danish clandestine groups carried out a number of reprisals, destroying or vandalising several buildings and memorials associated with the minority and with Germany. ${ }^{49}$ This included, for example, the bombing of a German 1864-war victory monument in Dybbøl and the landmark 'Bismarck Tower' north of Aabenraa. Furthermore, the hostile atmosphere between Danes and Germans in the border region made it outright dangerous to work to reconstruct a German school system. In June 1946, Peter Jepsen of the school association received a letter from an anonymous group threatening that:

[i]f you do not immediately abandon your plans for a [German] school, from this day on you will not be able to consider yourself safe either day or night [...] it may not be that we bomb you; we can also seize you [...] For example, I am the owner of an electrical iron ring which can be fitted to the head and connected to a current. ${ }^{50}$

In 1945 and 1946, German minority education and the minority as a whole were under pressure from the Danes. However, a distinction needs be made between the positions of the government and some politicians and the positions of the resistance movement and some other groups. The context within which the reconstruction of

47 N.N., 'De Tyske Skoler i Sønderjylland', Folkeskolen (1945), 207.

48 Ibid.

49 See Inge Adriansen, Erindringssteder i Danmark (Copenhagen: Tusculanum, 2010)

50 Letter from 'de 18 ' to Herr Peter Jepsen i Uge, 10 Apr. 1946, ADV, DSSV. 
the minority's schools took place was in other words both accepting of the minority's right to live in North Schleswig but also hostile at same time.

In addition to the outside pressure coming from parts of the Danish majority, the German-minded group was also under pressure from within. As discussed above, many North Schleswig Germans had strong ties to the region where Danish and German culture, language and identity had existed side by side for generations. The fact that the minority shared their regional vernacular speech with the Danish-minded population meant that they could transition into the majority relatively easily. From a Danish perspective, assimilating into the majority was regarded as unproblematic: the German-minded were only re-discovering their real national identity.

The Danish view that the German minority could assimilate into the majority if they so desired also came to the fore in the Danish schools that took the children from the German schools that had been closed. During an oral history interview in 2013, a German minority man born in 1940 remembered his experiences in a Danish middle school in Sønderborg as mostly pleasant. The teachers, he recalled, treated him and other German minority children very well indeed. He remembered too, however, the feeling that the Danish school paid special attention to him and the seven other children in the class who came from German-minded homes. He was under the impression that teachers sought quite deliberately to influence influencing him in a national sense. ${ }^{51}$

Written accounts support the argument that Danish schools welcomed former German students and that the Danish schools consciously took measures to integrate the new students. In the winter of 1945 , Folkeskolen described the situation in North Schleswig, this time focusing on the integration of German minority pupils in the Danish schools. A school inspector from Aabenraa expressed his satisfaction with the developments and was quoted reporting that 'the integration of the German pupils [had been] successful beyond our expectations. ${ }^{52}$ He elaborated on the success by adding that:

I am pleased that the pupils from the German schools have not attempted to keep themselves isolated for example during the breaks. They tend to stick to the groups in which they have been placed and I am under the impression that the relationship is good. The pupils are fortunate in that they are all of different ages and this has been important. They have been placed in a way which - so to speak - drowns them in Danish pupils. In the classroom they have all been seated next to Danes. Naturally, some of the new students

51 Male born 1940, Oral History Interview by Tobias Haimin Wung-Sung (30 Jul. 2013).

52 N.N., 'Tyske Elever', Folkeskolen, e (1945), 147. 
have had trouble keeping up, especially if they come from German-speaking homes and are used to the gothic alphabet only. ${ }^{53}$

In a personal memorandum, librarian and chairman of Sprogforeningen (the Danish language association), Jakob Petersen made the Danish efforts even more explicit. Petersen wrote the following in 1951, but reflected upon the situation in 1945:

It is well-known that many in this country thought that the German minority was doomed, and that whatever was left of it would be taken care of by the Danish school system in a relatively short time. There was no doubt that the Danish-speaking children from German-minded homes enjoyed the Danish schools [...] The problem was that the same trust could not be extended to the children's parents and with that the battle was lost. ${ }^{54}$

In the first five years after the Second World War, the minority's greatest tasks were first to re-establish its institutions and second to keep German-minded North Schleswigers loyal. Changing from a German to a Danish national identity, however, was not unique to North Schleswig only: south of the border, a similar situation unfolded too. In the early years after the war, German-minded South Schleswigers joined the Danish minority in vast numbers. From a German point of view, however, this transition was ill tolerated. The following quotes provide an idea of how the minority viewed the parents of children placed in the Danish school. Commenting on the situation south of the border in 1949, the new head of the school association, Fr. Christensen, expressed his discontent in the following way:

Also amongst the German North Schleswigers such treason exists. Characterless weaklings exist in all places and at all times. Those who are not with us are against us. ${ }^{55}$

In 1953, when the assimilation of minority families into the majority appeared to continue, Christensen commented again on the matter:

Is it really the case that the German people have weaker characters than the Danes that, like a dog, they lick the boots of he who steps on them, that in times of hardship they follow the herd uncritically and thoughtlessly, that their German-ness is only a varnish that can be scratched off? ${ }^{56}$

Fr. Christensen reacted so strongly because he did not accept that national identity could be changed. Born in North Schleswig in 1882, Christensen lived most of his life in the region, apart from shorter periods of time spent in Germany. $\mathrm{He}$

53 Ibid.

54 Jakob Petersen, 'Personligt memorandum: Mindretallets stilling nord for grænsen', 1 Jul. 1951, LAS, RA 1055, 1055/6.

55 Fr. Chistensen, 'Heimdeutschtum', Deutscher Volkskalender Nordschleswig (1949), 35.

56 Fr. Christensen, 'Vertraulich Rundschrieben', 26 Jan.1953, ADV, DSSV. 
belonged to the circle of people who favoured good relations with the Denmark and the Danish majority. Nevertheless, he vigorously opposed those who did not see the Danish and German nations as two clearly distinct and separate groups. As head of the German Language and School Association until 1955, he was probably the main early influence on the formulation and dissemination of a new German identity for post-war minority children and youths. Under his leadership of the school and language association, German minority identity was to remain unequivocally German in clear distinction from the Danish neighbour.

Christensen and the school association were not anti-Danish. Rather the contrary. In 1949, He wrote that:

To improve our relationship with the Danish people is our most urgent task, but to speak of this has rhetorical meaning only in so far as our equality as citizens is not recognised. ${ }^{57}$

In 1951, after highlighting the fact that over 3,000 German minority children were still attending Danish schools, Christensen made his view even more explicit:

None of this is a criticism of Danish schooling as such, everything is to be understood in relation to the educational questions of the German minority. The Danish schools are good and right for the Danes the way they are. We are different and hold different views regarding many important questions of schooling and education. We need German schools. ${ }^{58}$

By the early 1950s, the school and language association's building and establishing of new private schools gathered momentum. The association opened eleven schools in the month of January 1950 alone. In April, three more schools opened and in August an additional four followed. ${ }^{59}$ The schools opened in 1950 raised the total number from five to twenty-three. The school and language association were able to increase the number of schools so significantly mostly because the Danish government agreed, in 1949, to let the minority re-purchase thirteen confiscated schools. Yet even though, the Danish state showed more willingness to accommodate the minority's efforts, there was still the question of financing the expansion of the school system.

The school and language association worked on different levels in order to secure financial means. The association's archive contains copies of leaflets which encouraged members of the association and the minority in general to donate

57 Chistensen, 'Heimdeutschtum'.

58 Fr. Christensen, 'Neuer Anfang unseres Bildungswesens', Deutscher Volkskalender Nordschleswig (1951), 26-31.

59 Ibid. 
money privately. ${ }^{60}$ One leaflet said that 'the schools can receive some funding from the Danish state, but we have to build and equip them with our own means.61 In addition the association corresponded directly with the ministry of finance in Copenhagen, attempting to persuade the government to return as many buildings as possible that previously housed the closed-down schools. ${ }^{62}$ Finally, the association continued to look to Germany for support. In 1949, for example, it received $100,000 \mathrm{DM}$ in from the state of Schleswig-Holstein, constituting roughly one third of the total amount needed to re-purchase the thirteen schools. ${ }^{63}$

In terms of the Association's position vis-à-vis the national struggle in the border region, the schools were founded on the principle that the German- and Danish-minded in North Schleswig were two distinct groups that should be able to live side-by-side but not necessarily interact much. The schools wished to offer this understanding to German children, as made clear in 1952:

The children must achieve a clear awareness of the fact that our homeland (Heimat) is not Danish land and never has been. For one thousand years, it was neither German nor Danish and here we have something to preserve. ${ }^{64}$

With this statement the school and language association also referred to a regional conceptualisation of North Schleswig, which actually served two different purposes. First, it still rejected the Danish conventional wisdom that North Schleswig was Danish only, but second, it denounced the opposing idea that it unambiguously belonged to Germany. The new conceptualisation thus defined a space towards which the German minority could direct its loyalty.

The regional focus that considered North Schleswig to be a distinct, clearly defined unit was new. Previously, the German minority at large had self-identified either with the Schleswig-Holstein movement or the greater German nation. This new North-Schleswig focus was particularly clear in a memorandum by Fr. Christensen from 1953 which called for a history of the region to be written. Christensen envisaged a book covering twenty-eight topics, starting with the first human settlements on the edges of the ice-cap. Further chapters included the

60 Der Deutsche Schulverein für Apenrade, 'Helft mit am Aufbau einer deutschen Schule in Apenrade, 1946, ADV, DSSV.

61 Ibid.

62 Dr Reuter, Deutscher Schul- und Sprachverein to Finansministeriet, 21 Nov. 1948, ADV, DSSV.

63 Fr. Christensen, 'Neuer Anfang unseres Bildungswesens', Deutscher Kalender für Nordschleswig (1951), 28.

64 Fr. Christensen, 'Rundschrieben', 1952, ADV, DSSV. 
early-medieval 'Danish conquest' and 'North Schleswig architecture, marshland and great men'. It would conclude with the nineteenth-century 'national awakening' and the 'Prussian period [between 1864 and 1920] with its good and bad features.' ${ }^{\prime 6}$

From the early 1950s onwards, the minority focused on consolidating their identity with the region, and all previous talk about changing the border disappeared completely. The impact of this on older children and youths was clear. With only kindergartens and primary schools in North Schleswig, efforts were made to keep children and youths in the region. The educational options were organised to lead to professions relevant for a life in rural North Schleswig. Focus for boys was on agriculture and the trades, and for girls overwhelmingly on housekeeping. From 1951 onwards, preparation for professional life could take place in the new vocational training and boarding school in the small town of Tinglev, a minority stronghold, just north of the border. Originally a school of education for young people and adults, the reorganised boarding school offered six-month programmes for 14 to 18 -year-old boys and girls as well as agricultural training programmes for young men over the age of $18 .{ }^{66}$

Keeping young people in the region became one of the minority's main concerns. In the Volkskalender of 1956 (written in 1955), the concerns were articulated in this way:

All education, in so far as it causes young people to leave the region, is damaging to us, under some circumstances perhaps even deadly. It is better to be a smallholder in one's homeland [Heimat] than a steward in Zealand. It is better to be an office clerk in the homeland than office manager in Copenhagen. ${ }^{67}$

This quote illustrates how even if greater opportunities were to be found elsewhere in Denmark, the minority still urged youths to stay in North Schleswig. These priorities were connected to the fact that German secondary education no longer existed after 1945 when the German Grammar school (Gymnasium) in Aabenraa had been closed down. In 1955, however, the minority regained the right to offer education that qualified students for higher education. With money raised primarily in Schleswig-Holstein, the minority managed to initiate the reconstruction of a grammar school that was ready in 1958. The right of German schools to set

65 Fr. Christensen, 'Rundschrieben', 1953, ADV, DSSV.

66 Nachschule Tingleff, dir., 'Nachschule Tingleff', Museum Deutsche Volksgruppe, Sønderborg, Denmark.

67 Deutscher Volkskalender Nordschleswig (1956), 95. 
exams was reintroduced in connection with the Copenhagen Declaration, which clarified the rights and obligations of the Danish state and the German minority.

In reality the Copenhagen Declaration was just one element in a much larger settlement that facilitating West Germany's entrance into NATO.$^{68}$ It mirrored the Bonn Declaration, which clarified the relationship between the Danish minority south of the border and the West German Republic. Although these two declarations were products of the consolidation of the Western Alliance in the context of the Cold War, their impact on the minorities in the Danish-German border region was substantial. Contemporary scholarship celebrates the declarations as turning points, although such a conclusion is only possible with the benefit of hindsight. Especially south of the border, but also north of it, the minorities remained sceptical of what the implications of the declarations actually were, as Fr. Christensen noted:

Have the Danish people finally accepted that a German group lives within their borders, and will they grant this group free development of its cultural life, that is the spiritual and mental connection to the German nation? ${ }^{69}$

Another principal focus of German schools was on strengthening the connection to the German cultural sphere. In this regard, language was the minority's greatest obstacle. Without sufficient skills in the German language, it was argued, children of the minority would not be able to maintain a connection to the German nation or, as it was called, their spiritual homeland. ${ }^{70}$ The school association formulated the problem in this way:

It is well known that the German minority with only a few exceptions speak Low Danish at home. Only a fraction of the students understand German when they start school. Without knowledge of German, there is no German life [...] Without German schools, no German daily, no German library, no German service and German church, and no German society. ${ }^{71}$

The minority coped with the collapse of the Third Reich by focussing on a regional belonging in North Schleswig, a legal commitment to Denmark, and a spiritual connection to German language and culture. But sources suggest that - even

68 Karl Christian Lammers, 'Living Next Door to Germany: Denmark and the German Problem, Contemporary European History, 15, 4 (2006), 453-72.

69 Fr. Christensen, 'Stand und gesetzliche Grundlagen der deutschen Schule Nordschleswig', Deutscher Volkskalender Nordschleswig (1956), 89-92.

70 Arthur Lessow, 'Das deutsche Schulwesen in der Entwicklung', Deutscher Volkskalender Nordschleswig (1957), 83.

71 Fr. Christensen, 'Rundschrieben', 1952, ADV, DSSV. 
though the relationship between Danes and Germans improved tremendously in the post-war decades - German life in North Schleswig was still subject to both external and internal pressures. Fourteen years after the war, the school association believed that some parents still chose the Danish school over the German one because they felt pressured to do so by the Danish majority. The new head of the school association, Arthur Lessow, argued:

Alongside the many positive surprises regarding the school registrations, we have also experienced bitter disappointment when parents who both consider themselves to be German [...] register their children in the Danish schools. It is clear to us that some parents do not dare to register their children with us [...] We hope for the day when, free from fear, parents can register their children in the German schools. ${ }^{72}$

It could be possible too, however, that some parents chose the Danish school over the German one for other reasons. The insular identity of the minority's core perhaps no longer suited the world-view of youths and younger parents. By the early 1960s, most young parents would have been born after 1920 and had no active recollection of the changing of the border. In other words, they were born into the minority and had no experience of becoming one as a consequence of a border revision. Their principal experience as part of the German minority would have been the Nazi era and the difficult years after the war. The evidence suggests that the old isolationist tendencies no longer appealed to young people.

The first graduates from the reconstructed high school, for example, challenged the isolationist tradition when they graduated in 1962. The minority was thrilled to have secondary school graduates in North Schleswig again after a seventeenyear absence. The minority's daily, Der Nordschleswiger, wrote on the day they graduated how important this first cohort of school leavers was because 'obviously we hope that many more graduates will follow and so as the class of 1962. That is how traditions actually arise. ${ }^{73}$

The minority establishment did not appear to have envisaged, however, that these new traditions would include graduates choosing to wear the same graduation caps as their Danish peers. The graduates were entitled to wear the traditional Danish graduation caps in the Danish red and white colours. The Copenhagen declaration of 1955 had ensured that a graduation diploma from the German Gymnasium was fully valid in both Germany and Denmark. Some in the minority, especially the now retired Fr. Christensen, thought that adopting the Danish tradition was a step too far. He argued in the daily that, 'in my opinion we accommodate

72 Arthur Lessow, 'Jahresbericht', 1958/1959, ADV, DSSV.

73 N.N., 'Wieder deutsche Abiturienten', Der Nordschleswiger (15 Jun. 1962). 
the Danes too much, that is when one expects their respect for our unconditional sincerity $[\ldots]$ Do we not have our own traditions? ${ }^{34}$

The Danish minority in South Schleswig also noted how the German graduates wore the red and white caps. It expressed some surprise, but did not challenge the German minority students The Danish-minority daily in South Schleswig wrote about the incident as follows:

Certainly other people [the Danish majority] should not feel the need to prevent this! The Danish graduation cap does not become German because some Danish citizens of German identity wear it ... Conversely, we must admit: we would not be happy to see our youths from the Danish upper-secondary school in Flensburg celebrate their graduation with a German graduation cap. ${ }^{75}$

The debates over the graduation caps illustrate the changes to North Schleswig German identity starting in the early 1960 's. German-minded youths no longer regarded it as necessary to live in isolation from the Danish majority. Even the first graduates from the reconstructed high school - the elite of minority youth - did not consider their identity compromised or threatened by adopting the tradition with the caps. A few years later, in 1965, the school association for the first time explicitly added this dimension to its traditional focus on giving children access to the wider German cultural sphere:

The students that leave our schools are at home in both languages and both cultural spheres of our border region. Exactly that makes them capable of working here in their native region where two nations meet. ${ }^{76}$

Twenty years after the end of the Second World War, the German minority had completed the material reconstruction of its school system but for the first time since 1945, the number of new students stagnated. ${ }^{77}$ The school association reflected upon the stagnation but perceived it primarily as the result of having completed a successful reconstruction of the school system. ${ }^{78}$ The minority started focusing on new conditions challenging the German schools, and in doing so, the school association only became even more inclusive of its Danish dimension. In 1968, the purpose of the German education system was defined as follows:

74 Fr. Christensen, 'Die rot-weißen Mützen', Der Nordschleswiger (26 Jun. 1962).

75 N.N., 'Studenterhuen', Flensborg Avis (22 Jun. 1962).

76 Arthur Lessow, 'Schlussbetrachtung', Deutscher Volkskalender Nordschleswig (1965), 79.

77 Arthur Lessow, 'Schlussbetrachtung' Deutscher Volkskalender Nordschleswig (1966), 75-77.

78 Ibid. 
Always in the foreground of our efforts is the student who is entrusted to us. To equip him with the necessary knowledge and skills, to educate him to become an independently thinking and pro-active human, who is at home with the German language and connected to the German community, but to whom also the Danish language and cultural sphere is not foreign. That is the goal of our school and education work in North Schleswig. ${ }^{79}$

By 1970 the school association stated more unequivocally than ever before that it pursued a dual mission in seeking both to introduce students to German language and culture and to prepare them for a future in the Danish state. ${ }^{80}$ This dual mission, it argued, was undertaken 'without recourse to an exclusionary nationalism but in close connection to our nation and with ever more determination to connect the two nations of our border region. ${ }^{81}$

\section{Conclusion}

After a century of national contestation over Schleswig, the border drawn between Denmark and Germany in 1920 carved out North Schleswig from the former duchy and created a strong and separatist German-minded minority in Denmark. Although accommodated by the Danish state, the interwar minority retained separatist aspirations. It strongly supported the Nazi regime and it agitated for the region's incorporation into Nazi-Germany. Immediately after Germany's capitulation in 1945, elements within the minority untainted by Nazism assumed leadership of the North Schleswig Germans. Stressing their loyalty to the Danish state and unequivocal recognition of the 1920 border, they defined North Schleswig German identity henceforth as fundamentally loyal to Denmark and anti-separatist.

The German minority in Denmark did not suffer the same fate as many other Germans who lived in European borderlands, but the liberal minority policies of the interwar years were changed after 1945, and the reconstruction of German education after 1945 took place under pressure. From the winter of 1945, a new law established that German education could take place only in private schools. These would first have to be (re)built as pre-war buildings were confiscated by the Danish state. This meant that a large number of children were transferred into Danish schools. According to the minority, this severely compromised its chances of long-term survival.

79 Arthur Lessow,'Schlussbetrachtung', Deutscher Volkskalender Nordschleswig (1968), 74.

80 N.N.',50 Jahre deutsche Schularbeit', Deutscher Volkskalender Nordschleswig (1970), 95-98.

81 Ibid. 
The pressure on the minority came not only from the Danish majority. The fact that many North Schleswig Germans voluntarily chose to assimilate into the majority threatened the minority's continued existence and was fiercely contested by its leadership. This identity transformation was possible because North Schleswig Germans shared many cultural traits with the majority North Schleswig Danes, for example, their regional vernacular speech. Furthermore, many Danes accepted the transformation because they continued to see the minority as Germanised Danes who had merely forgotten their true national identity.

The reconstruction of a German education system was embedded in this context. North Schleswig German identity as communicated in schools was always tied to German language and culture, but other layers were added to their selfperception of identity. In the early years after the war, the school and language association continued to stress the clear distinction between majority and minority, between Danes and Germans. From the early 1950s, however, the minority began to focus more on its regional ties, verbalising how it belonged to North Schleswig as an independent region influenced by both Danish and German culture. As the pressure on the minority diminished, the school and language association began to articulate a Danish dimension too by the 1960s.

The reconstruction process of the education system from 1945 to c. 1965 included substantial changes to North Schleswig German identity: the children who attended minority schools in 1965 were offered a completely different minority identity from that which had been offered to children attending German schools before 1945. The transmission of North Schleswig German identity was no longer separatist and isolationist but, rather, now embraced North Schleswig's national diversity. The new identity was inclusive and even took pride in asserting the role of the minority as a group that understood both the Danish and the German nations. Even though the minority thought they would always 'remain what they were', in reality their national identity as North Schleswig Germans had changed as much as the society of which they formed a part. 


\title{
Generational Conflicts, the Spirit of ' 68 and Cultural Emancipation in the German Speaking Community of Belgium. A Historical Essay About the ' 73 Generation
}

\begin{abstract}
Changes were in the air' - is perhaps the best way to describe the social mood at the end of the 1960s and the beginning of the 1970s. On the international stage, the gap between the post-war generation, known as the 'baby boomers' and the generation that had experienced World War II as adolescents or young adults came to light in the form of student protests, anti-war movements and new concepts of life. It is scarcely a coincidence that there were protests in eastern Belgium too at this time. What were the 'young wild ones' protesting against in the German speaking region of Belgium? Based on a generational approach, this article aims at contextualizing the autonomy-debate in the late 1960s and early 1970s by focusing on a historical investigation into a few young people in the Eifel region that would strike new political tones with lasting influence on the political landscape as well as on the social or cultural environment of eastern Belgium.
\end{abstract}

Sankt Vith, 19 May 1968. A few days after the first 'night of the barricades' in the Quartier Latin and the start of the largest nationwide strike in the history of France, Dr Michel Kohnemann, a teacher of German at the Collège Patronné in Eupen and President of the German-speaking section of the European Association of Teachers (EAT) gave a lecture entitled 'German eastern Belgium in the Europe of tomorrow' to bring the EAT information days in Sankt Vith to a close. The core theme of his lecture was the question as to whether the German-speaking Belgians can act as 'mediators' between 'Romance and Germanic language and culture.' 'After years of linguistic and cultural indifference on the part of administrators and citizens alike', Kohnemann stated at the outset of his lecture, 'this insight suddenly seems to be the magical formula for the paradisiacal future of our region.'

1 Michel Kohnemann, 'Deutsch-Ostbelgien im Europa von Morgen' [German-speaking eastern Belgium in the Europe of tomorrow], lecture given to bring to a close the information days of the German-speaking section of Belgium at the European Association of Teachers, Sankt Vith, 19 May 1968, 10 type-written pages, here 2. Albert Gehlen's private archive. 


\section{Actions speak louder than words}

Whereas Kohnemann's remarks were aimed at giving cultural and political legitimacy to the political concept of 'German-speaking eastern Belgium,' we are here interested primarily in the conclusions that he drew at the end of his lecture. These were directed particularly to the 'student youth', whose drive for the realisation of the European idea would hopefully lead to the emancipation of German-speaking eastern Belgium. ${ }^{2}$ The educator from Raeren expressly warned at the end of his lecture, 'all lectures, discussions, etc. must certainly not overshadow the fact that what ultimately counts is what has been accomplished, not what has been discussed and planned. Action-minded people are needed to that end, for otherwise things will peter out.'

Kohnemann's call tapped into the spirit of the time. The mid 1950s witnessed the rise of resistance on the cultural and political front in eastern Belgium against the massive Frenchification and pressure to assimilate to which most Germanspeaking Belgians were exposed in the first decade after the war. The establishment of cultural associations such as the Volksbildungswerk [National Educational Organisation] (1957), the Verein zum Schutze und zur Pflege der Muttersparche [Association for the Protection and Cultivation of the Mother Tongue] (founded likewise in 1957, later renamed Bund der Deutschbelgier [Federation of Germanspeaking Belgians] under the leadership of Dr Leondard Schifflers MD, from Kelmis) as well as newspapers such as the Neue Nachrichten (1955) and St. Vither Zeitung (1955) provided outlets for the articulation of German-speaking interests in the mid 1950s. What distinguished these initiatives and made them similar (at least in their intention), was the focus on the language issue. The protagonists of these associations or bodies were hoping to raise political awareness through the recognition and promotion of the German language. Many linguo-political activists held the firm conviction that the people of eastern Belgium could preserve their cultural identity only if their right to the equitable use of their own language in the Belgian state structure was guaranteed.

This demand for cultural recognition of the German-speaking region was of course enshrined in the Belgian Constitution de jure with what is known as the Languages Act of 2 August 1963, but the equal treatment on the language front remained de facto wishful thinking for a long time. Turning such thinking into

2 'And when I say Europe, I am referring in the same breath - and as a condition sine qua non, so to speak - to the reflection on the true values of a linguistic and cultural nature in German-speaking eastern Belgium,' Ibid., 10.

3 Ibid. 
fact would be essentially the work of a new generation of cultural autonomists which were consciously or unconsciously inspired by the ' 68 movement and took action to bring about the actual transformation of social relations. But were the new minds of the autonomy debate - whom I would provocatively like to describe hereinafter as the ' 73 generation - actually committed to the ideology of historical materialism, according to which the social being determines awareness and not vice-versa? Can the radicalisation of the political autonomy discourse in the beginning of the 1970s be historically understood as a generational conflict, i.e. more as an expression of different socialising and biographic patterns than as a result of political or ideological contentions? To get to the root of this complex issue, the biographical background of some of the protagonists of the autonomy debate will be reconstructed in what follows, without any claims to a collective biographical study. ${ }^{4}$ To that end, interviews were conducted with contemporary eyewitnesses which focused prominently on the question as to how political commitment - in the widest meaning of the term, i.e. to parties but also to language, culture or society - came about. ${ }^{5}$

\section{A short historical contextualisation}

But before entering into the discussion of the questions raised above, a short historical retrospection might be necessary in order to put the story into the right political and social context. The region under consideration in this chapter, now called 'German speaking Community of Belgium' and one of the three member states of Belgian Federation, only became part of the Belgian Kingdom after the First World War. During the negotiations of the Peace Treaty of Versailles in 1919, the two German cantons of Eupen and Malmedy which had been part of the Prussian Empire since the Treaty of Vienna in 1815 became part of the compensations of the Allied and Associated Powers. These so called reparations were imposed upon the Central Powers during the Paris Peace Conference, and the Belgian State had great hopes in expanding its territory at the expanse of

4 On the topic of collective biography as a research strategy, cf. Wilhelm Heinz Schröder, Kollektivbiografie: Spurensuche, Gegenstand, Forschungsstrategie, in: Historical Social Research, no. 23 (2011), 74-152.

5 The author conducted oral history interviews with the following persons (in alphabetical order): Freddy Derwahl, Joseph Dries, Albert Gehlen, Georges Kalf, Robert Oberecken, Lorenz Paasch, Gerhard Palm, Wilhelm Pip, Leonard Schifflers, Richard Schwall, Peter Thomas, Alphons Thunus. Heartfelt thanks are once again in order here to all participants for attending and for their preparedness to provide information. 
Germany as compensation for its great losses and violation of neutrality during the war. ${ }^{6}$ That the Belgian delegation finally had to content itself with little - that is the two small districts at the very East of its territory - was clearly a great disappointment for the Belgian representatives, but they nevertheless accepted to organise a plebiscite in early 1920 aiming at incorporating the territory into the Belgian state. As has been demonstrated by numerous scholars, this plebiscite was in fact a 'farce' as it was not a secret ballot and took place under the auspices of the Belgian authorities, more precisely under the sovereignty of the Royal High Commissioner General Herman Baltia. ${ }^{7}$ Baltia, who had served the Belgian Army in the Kongo, had the delicate task prepare and manage the formal integration of the two districts into the Belgian state during a five year transition period which ended officially in 1925.

Although in 1926 the Weimar Republic conducted secret negotiations with Belgium about a return of the territory to Germany which eventually failed due to French intervention ${ }^{8}$, the interwar years showed a slow but steady political, juridical and economic integration of Eupen-Malmedy into the Belgian state. This process was characterized by a high degree of pragmatism or 'situational opportunism' by the local population who tried to come to terms with these new political realities. ${ }^{9}$ This pragmatism became challenged with the rise of National Socialism in Weimar Germany and certainly after the accession of power by Adolf Hitler in January 1933. The pro-German propaganda and subversive Nazi activities in the former German territories clearly led to a radicalization of the political discourse in Eupen-Malmedy in the mid 1930s. The creation of a new political party named 'Heimattreue Front' (HF) in 1936 was the most obvious sign of a rising irredentist current in the region, yet the overtly anti-Catholic ideology of the National Socialist movement eventually got in the way of acquiring a majority of votes during the last democratic elections in 1939 (the HF nevertheless received $45.1 \%$ of the votes).

6 Klaus Pabst, Eupen-Malmedy in der belgischen Regierungs- und Parteienpolitik: 1914-1940, in: Zeitschrift des Aachener Geschichtsvereins Bd. 76 (1965), 205-515.

7 On Herman Baltie see the edited memoirs by Els Herrebout (ed.), Generalgouverneur Herman Baltia. Memoiren 1920-1925. Brussels: Generalstaatsarchiv 2011.

8 Manfred Enssle, Streseman's Territorial Revisionism: Germany, Belgium, and the EupenMalmedy Question 1919-1929. Stuttgart: Franz Steiner Verlag 1998.

9 See Carlo Lejeune, Andreas Fickers, Freddy Cremer, Spuren in die Zukunft. Anmerkungen zu einem bewegten Jahrhundert. Büllingen: Lexis Verlag 2001. 
With the outbreak of the Second World War and the German invasion to Belgium in May 1940, the former Prussion districts of Eupen and Malmedy were officially reincorporated into the German Reich. Despite the fact that this annexation meant a violation of international law, the Belgian exile government did never protest officially against the de facto reintegration into German territories. ${ }^{10}$ For many people of Eupen-Malmedy, the 'Heim ins Reich' enthusiasm that had characterized the public sphere right after the annexation soon turned into a more reluctant and clearly chilled exaltation, especially after the start of recruiting the male population for the Wehrmacht in the summer of 1941. Both the many losses during the war and the devastations in the region during the 'battle of the bulge' (Rundstedt Offensive) in the winter of 1944/1945 left bitter traces of this fateful episode in the collective memory of the region. Yet the harsh repressions of the Belgian state against the German-speaking population in the immediate postwar years during the so-called 'purge' ('Säuberung' / 'épuration') did anything but facilitate the successful 'assimilation' of the population. ${ }^{11}$ It was during these 'dark years' that most of those that I want to qualify as the ' 73 generation were born as part of the 'war child generation'.

10 Martin Schärer, Deutsche Annexionspolitik im Westen. Die Wiedereingliederung EupenMalmedys im Zweiten Weltkrieg. Bern: Peter Lang Verlag 1978.

11 Freddy Cremer, Als man den aufrechten Gang wieder lernen musste. Von den 'inciviques' zu den 'Modellbelgiern', in: C. Lejeune, A. Fickers, F. Cremer, Spuren in die Vergangenheit, 99-116. 


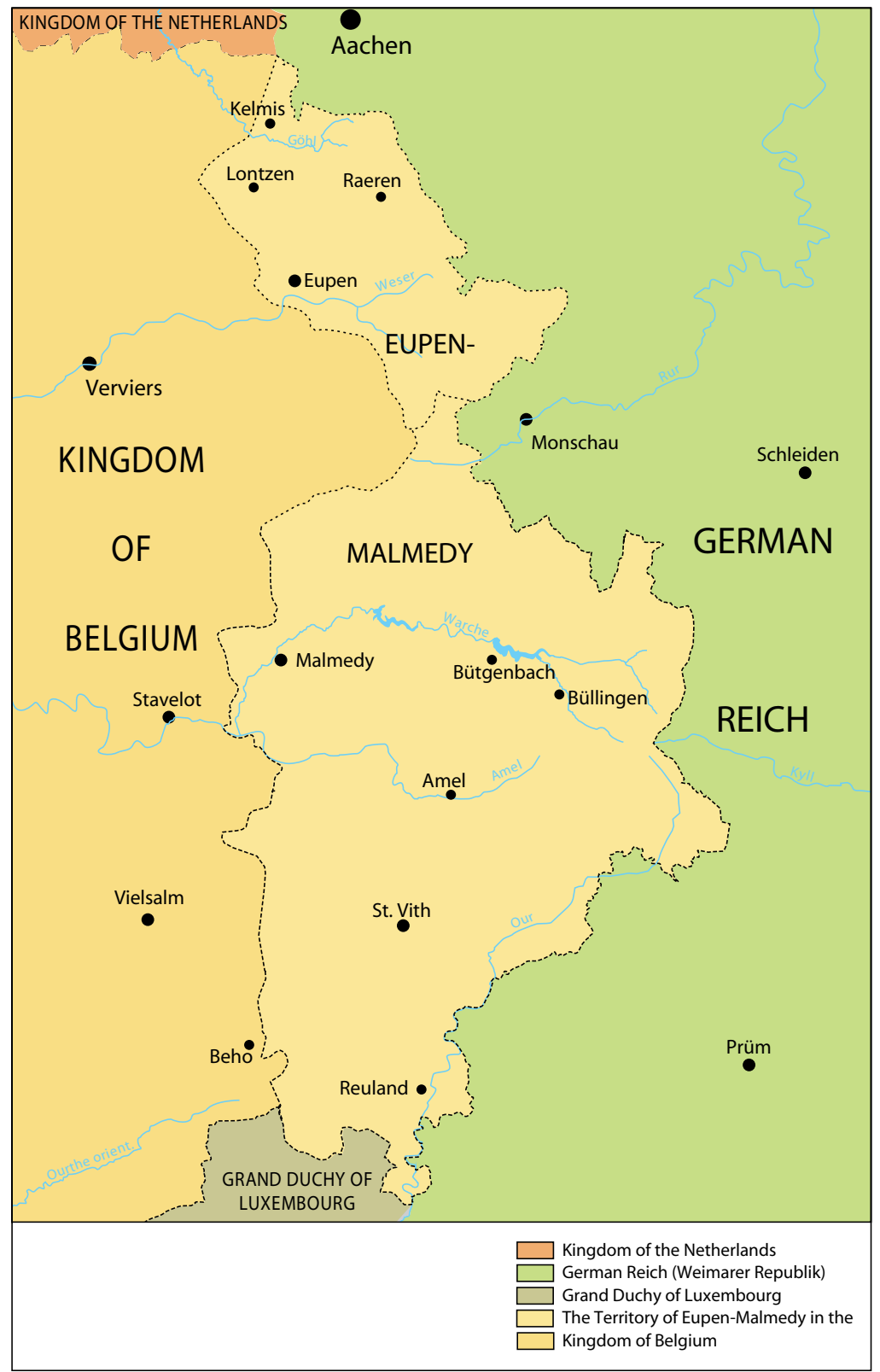

Map 6: The Border Regions After the Treaty of Versailles (1920). 


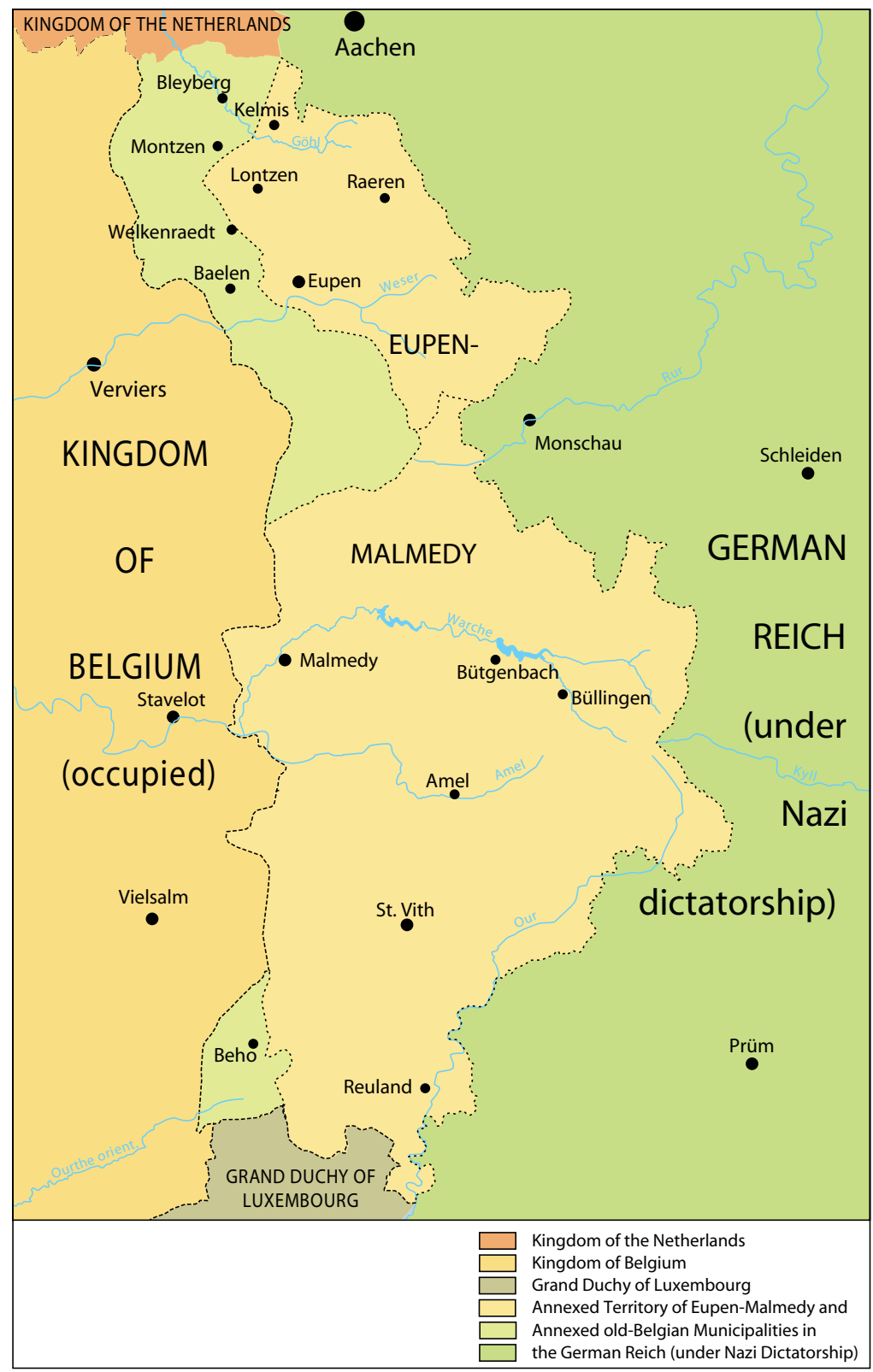

Map 7: The Border Regions During the Second World War (1940-44). 


\section{Questions addressed to the ' 73 generation}

The idea of turning generational sequences into limited timeframes and thus into fruitful patterns for explaining historical chronologies is as old as historiography itself. ${ }^{12}$ Similarly, the consideration that the basic form of human understanding is to be sought in the biographical experience itself, is firmly embedded in our thinking. Nevertheless, the concept of generations, understood as experience of a certain group of people, as a historical category of interpretation is not without problems. The concept of generations has of course found its way into the interpretive repertoire of historians as an analytical category (since the pioneering study of Heidelberg sociologist Karl Mannheim, 'Das Problem der Generation' from 1928$)^{13}$, yet the definition as to what we are to understand by 'generation' remains contentious, and the generalisation of individual experiences (which is necessarily related to that concept) to an entire cohort, remains problematic. ${ }^{14}$

Inspired by Mannheim and the sociological tradition of generation research, I would like to use the concept of generations, following Bernd Weisbord ${ }^{15}$ and Benjamin Möckel $^{16}$ in particular, to ask the following questions:

12 Cf. Ohad Parnes, Ulrike Vedder, Stefan Willer, Das Konzept der Generation. Eine Wissenschafts- und Kulturgeschichte, Frankfurt am Main: Campus 2008.

13 Karl Mannheim was aware of the temporal and thematic complexity of the concept of generations. His attempt to draw a distinction between generational strata (an affiliation to a cohort based on age), generational contexts (an experience for a group stemming from historical and social grounds) and generation units (an affiliation to a certain group stemming from social and cultural differentiation), was ultimately motivated by the concern to seek out what are known as 'entelechies' (also referred to as 'aspiration' or 'world aspiration') as the origins of dynamics behind social change in society. Cf. Karl Mannheim, Das Problem der Generation, in: Kölner Vierteljahrshefte für Soziologie 7 (1928), Issue 2, 157-185, and issue 3, 309-330, and Lutz Niethammer, Die letzte Gemeinschaft. Über die Konstruierbarkeit von Generationen und ihre Grenzen, in: Bernd Weisbrod (ed.), Historische Beiträge zur Generationsforschung, Göttingen: Wallstein Verlag 2009, 13-38.

14 For a recent discussion of the theoretical and methodological challenges of using the concept of generation for doing contemporary history see Hartmut Berghoff, Uffa Jensen, Christina Lubinski, Bernd Weisbrod (eds.), History by Generations. Generational Dynamics in Modern History. Göttingen: Wallstein Verlag 2013.

15 Cf. Berndt Weisbrod, Generation und Generationalität in der Neueren Geschichte, in: Aus Politik and Zeitgeschichte 8/22005. Online at http://www.bpb.de/apz/29215/ generation-und-generationalitaet-in-der-neueren-geschischte? $\mathrm{p}=$ all.

16 Benjamin Möckel, Erfahrungsbruch und Generationsbehauptung. Die 'Kriegsjugendgeneration' in den beiden deutschen Nachkriegsgesellschaften. Göttingen: Wallstein Verlag 2014. 
- Do the generational references of the ' 73 generation result more from a constituent event ${ }^{17}$ (such as World War II) or through structural conditions (such as growing up in the 'post war period')?

- Is the '73 generation an 'elite' shaped by a certain core group? Or are we dealing with a collective phenomenon?

- To what extent can the ' 73 generation be considered as a founding generation' which broke with established structures? Or is it more of a 'transitional generation,' which connects old and new and whose characteristics stem from the dynamic of historical continuity and social change?

- And finally: Is the ' 73 generation - similar to the much acclaimed ' 68 generation - actually a concrete experience generation or a subsequently constructed 'narration generation' which is based more on a biographical or medial recollection construct than historical reality?

\section{Tensions between generations}

When the Board of the German Cultural Society convened for its inaugural session on 23 October 1973, it was attended by 25 party delegates who had been chosen by an electoral college in accordance with a proportional representation process (based on the number of votes that the parties had received at the last elections for the lower and upper houses of parliament on 7 October 1971). By decision taken by the federal parliament in Brussels on 29 June 1973, the members of the board would be elected directly as of the next parliamentary elections. ${ }^{18}$ A glance at the portraits of the 25 delegates published in the Grenz-Echo issue of 23 October 1973 clearly shows that the board was composed of a very young generation of politicians. The average age was just over 40 , but most of the board members were in their early-to-mid 30s, and thus born during or shortly after World War II. ${ }^{19}$ The youngest delegate was the first 26-year old speaker of the Party of German-speaking Belgians, Lorenz Paasch, who was the only board member

17 Introduced into the discussion as 'cohort defining event' by the American sociologist Normal Ryder, cf. Norman B. Ryder, The cohort as a concept in the study of social change, in: American Sociological Review, Vol. 30 (1965) no. 6, 843-861.

18 Cf. Hubert Jenniges, Der lange Weg der deutschen Sprachgemeinschaft zur Kulturautonomie, transcript of the programme of the same name broadcast by the BHF on 27 October 1973,22. The first direct election of such officials took place on 10 March 1974. For the results of the election and the distribution of seats, cf. http:www.dgparlament. be/desktopdefault.aspx/tabid-676/978_read-18662/.

19 To this cohort belong in particular Albert Gehlen (CSP, born in 1940), Herbert Genten (CSP, born in 1942), Erich Krafft (CSP, born in 1942), Emil Mertes (born in 1939), Fredy 
from the post-war generation. In addition to this group of young delegates, there was naturally a series of 'established' local politicians in the ranks of the board as well, such as Hubert Cremer, August Pitsch, Félicien Déjozé and Michel Louis, whose cohort could be exemplified by Christian-Social (CSP) politician Johann Weynand (born in 1923), who was elected by the delegates as the first president of the board by a wide majority.

The composition of the first Board of the German Cultural Society is in certain respects symptomatic of the generational tension that comes to the fore in the ' 73 generation. Two genealogically separated generations meet therein - the older generation, which had concrete experience of the war as young adults (partially as soldiers in the Wehrmacht), and the younger generation, which was born during or shortly after the war, and whose political and cultural socialisation had taken place essentially in the first decade of the post-war period. ${ }^{20}$ Whereas World War II undoubtedly represented the most defining biographical experience for those born in the 1920s, which was processed psychologically and politically in the post-war years, the political and cultural socialisation of the 'war children's generation' (1930-1945) occurred at a time when World War II left an indirect mark on the living environment of that generation whether through the painfully experienced absence of fathers or other family members, who had perished in the war or were imprisoned, or through the experience of destruction, Spartan living conditions and repression, which marked the lives of many eastern Belgian families in the post-war period. ${ }^{21}$

Whereas the generational context of those who had experienced (and survived) the war as adults stemmed particularly from the common experience of the war and its material, political and socio-psychological consequences, it was precisely the indirect presence of the war and its after-effects that shaped the generational

Dupont (SPB, born in 1942), Jean Cremer (SPB, born in 1938), Bernd Gentges (PFF, born in 1943).

20 In the current research literature, the 'war children's generation' comprises the cohort born between 1930 and 1945 .

21 The father of two of the interviewees did not return from the war - either because he had died (as was the case of Albert Gehlen) or because he did not return to his family (as was the case of Robert Oberecken). In many families, if the father had been in the Wehrmacht or been involved in organised politics, he was incarcerated in Belgian prisons for shorter or longer periods of time. This absence of the father was also a traumatic experience for the war children's generation. 
context of the war children's generation. ${ }^{22}$ This indirect presence of the war for the war children's generation paradoxically found its most pronounced expression in the absence of the public (and very often also private) thematisation and problematisation of concrete war experiences by the war generation. This presence of the absent would mark not only the war children's generation, but also the post-war generation (1945-1955) from which the protagonists of the " 68 generation would later stem. Generation research has hitherto focused extensively on the war generation $^{23}$ (both on the perpetrators and the victims of that generation) as well as on the political generation of $68{ }^{\prime 24}$ Generation research has recently refocused on the war children's generation, however. ${ }^{25}$ Designated by Sabine Bode as the 'forgotten generation, this generation is distinguished above all by its often repressed (partially traumatic) war experiences in childhood, as well as by the systematic taboo status or silence about the war time in the adolescent phase. ${ }^{26}$ In eastern Belgium, this repression of the past often extended to the 1930s, during which the political confrontation between pro-Belgian and pro-German minded eastern Belgians had become increasingly radicalised. ${ }^{27}$

For the ' 73 generational, there is thus a clear generational tension, which is also reflected in a different political consciousness. Whereas the political day-to-day activities of those members of the war generation who became politically engaged in the post-war period were essentially determined by topics which were directly

22 For the complex transgenerational links between the war and post-war generation, cf. Anne-Es Ustorf, Wir Kinder der Kriegskinder: Die Generation im Schatten des Zeiten Weltkriegs, Freiburg: Herder Verlag 2008.

23 Cf., e.g. for the 'perpetrator generation' Sönke Neitzel/Harald Welzer, Soldaten. Protokolle vom Kämpfen, Töten und Sterben, Frankfurt am Main: Campus Verlag 2011. For the political generations in the $20^{\text {th }}$ century in general, cf. Stephen Lowell (ed.), Generations in Twentieth Century Europe, Basingstoke: Palgrave/McMillan 2007.

24 Cf. Ingrid Gilcher-Holety, Die 68er Bewegung, Deutschland, Westeuropa, USA, Munich: Oldenbourg Verlag 2008; Jean-François Sirinelli, Mai 68. Lévénement Janus, Paris: Fayard 2008; Anna von der Goltz (ed.), Talkin' about my Generation. Conflicts of Generation Building and Europe's 1968, Göttingen: Wallstein Verlag 2011.

25 Cf. the conference proceedings: Die Generation der Kriegskinder und ihre Botschaft für Europa sechzig Jahre nach Kriegsende, 14-16 April 2005, Frankfurt, in: H-Sozu-Kut, 1.5.2005, http://hsozkult.geschichte.hu-berlin.de/tagungsberichte/id=766.

26 Sabine Bode, Die vergessene Generation. Die Kriegskinder brechen ihr Schweigen, Stuttgart: Klett-Cotta 2004.

27 Cf. Andreas Fickers, Gedächtnisopfer. Erinnern und Vergessen in der Vergangenheitspolitik der deutschsprachigen Beliger im 20. Jahrhundert, in: zeitenblicke 3 (2004), no. 9 [9.6.2004]; URL: http://zeitenblicke.historicum.net/2004/01/fickers/index.html 
or indirectly a consequence of World War II (such as the reconstruction or new construction of destroyed cities, infrastructures and institutions, the issue of men compelled to serve in the German army, or the recognition of disabled veterans and war widows), ${ }^{28}$ the political consciousness of the war children's generation took shape at a time that was often marked by pragmatism, forced assimilation efforts and pious recognition of the Catholic Church as the only true and valid moral (and often also political) authority. ${ }^{29}$ There were undoubtedly family and social occasions in the post-war period, where the past was broached and contemporary political issues became subjects of controversial discussions. Nevertheless, the assessment that certain topics should not be discussed ${ }^{30}$ prevails in the remembrances of contemporary witnesses, and any form of political engagement was viewed with scepticism when not outright rejected.

The fact that at the end of the 1960s, a small minority of the war children's generation or immediate post-war generation would nonetheless become politically engaged - often against well meant paternal advice to stay away from politics - is quite amazing. ${ }^{31}$ It would take politicisation from the outside - or so the hypothesis runs - to mobilise this depoliticised war children's generation on the social and political front - in both words and deeds.

28 Cf. Gerd Kleu, Neuordnung der Ostkantone Belgiens 1945-1956. Politik, Kultur und Wirtschaft in Eupen, Malmedy und Sankt Vith, Essen: Klartext Verlag 2007.

29 Nearly all the interviewees indicated that the Catholic Church - in both its institutional and moral dimension - was experienced as an all-powerful authority, from which one could be emancipated only with difficulty, if at all. A sound performance at secondary school to become 'suitable' (often on the recommendation of the pastor) often also meant, whilst being exposed to the wishes of the parents, examining one's conscience as to whether one felt called to 'greater things.' The overpowering presence of priests as teachers who set the tone in Catholic secondary schools as well as in boarding schools marked by strict rules, could generate additional pressure to give serious thought to a possible career as a clergyman.

30 These included, inter alia, the crimes of the Wehrmacht, the persecution of the Jews, the appeal - at least for parts of the population - of the existing Nazi ideology or resistance. Cf. Carlo Lejeune, Klaus-Dieter Klauser, Ein Wort vorab... Die verborgenen Wasserzeichen entdecken und lessen oder: Wie entsteht Wahrheit? In: Lejeune/Klauser, Die Säuberung, Verdrängte Errinerungen - 340 Zeitzeugen berichten, Vol. 3, Büllingen: Lexis Verlag 2008, 17-34.

31 Cf. the interview with Lorenz Paasch, in the Grenz-Echo of 24 January 2013. The words 'For god's sake, stay away from politics' are vividly remembered by many contemporary witnesses interviewed. 


\section{Schools shape ethical values in language conflict}

Since for many members of the war children's generation and immediate post-war generation, the parental home had fallen out as the place of political socialisation, the school became for most of them a place of confrontation with the political as well as cultural standards and values in the post-war period. ${ }^{32}$ During the harsh purge of the school system, between May 1945 and mid January 1946, 146 primary school teachers were declared 'unworthy' and dismissed. ${ }^{33}$ Replaced frequently by teaching staff who had only a rudimentary command of German if any knowledge of the language at all, the rigorous drive to Frenchify the school system in primary and secondary schools by force conducted by district commissioner Henri Hoen led to heated debates time and again. At the beginning of the 1950s, it became apparent to the Belgian administrative authorities that teachers in the school system had to be proficient in the German language. ${ }^{34}$ For those certified to have the necessary intelligence for further education, attending a secondary school automatically meant a purely French-speaking curriculum. The strong emphasis on the linguistic proficiency of students in secondary school with a view to higher studies at a French-speaking Belgian university doomed many intelligent, but perhaps less linguistically talented students. The language policy in education was essentially de facto responsible for the fact that eastern Belgian was a right down 'educational desert' until the end of the 1960s. ${ }^{35}$ 'Whoever was not linguistically talented to some degree, perished,' is how former professor at the Episcopal School and Sankt Vith resident Chaplain Wim Geelen summarised the situation in retrospect. ${ }^{36}$ Only religion was taught in German at the Catholic

32 Machteld Venken, Nationalization campaigns and teachers' practices in Belgian-German and Polish-German border regions (1945-1956), in: Nationalities Papers: The Journal of Nationalism and Ethnicity 42 (2014) 2, 223-241.

33 Cf. Kleu, Die Neurdnung, in particular Chapter 4: Die Neuordnung des Schulwesens, 77-96.

34 On the purge, cf. Carlo Lejeune, Die Säuberung. Hysterie, Wiedereingliederung, Assimilierung (1945-1952), Vol. 2, Büllingen: Lexis Verlag 2007.

35 On the deteriorating educational gap, cf. Carlo Lejeune, Von Tafel, Griffel, Rutenstock zur Bildung für alle. Der lange Weg zum lebensbegleitenden Lernen, in: Carlo Lejeune/ Andreas Fickers/Freddy Cremer, Spuren in die Zukunft, Büllingen: Lexis Verlag 2001, 49-61.

36 Wilm Geelen: 'We knew that we had to roll up our sleeves and scale down our claims', in: 75 Jahre Impulse auf der Eifel. Retrospektiven 1931-2006. Geschichte der Bischöflichen Schule St. Vith mit Daten und Fakten zu Ostbelgien 1920-2007, Sankt Vith 2007, 51. 
secondary schools in Sankt Vith and Eupen, because they wanted to make sure that the Catholic teaching was understood without any doubt!

It was this experience with a lack of equal opportunities in education, which elicited countless comments and letters from readers in the mid 1960s, and would find its structured articulation in the brochure written by Alphons Thunus in $1968 .{ }^{37}$ After completing his studies in theology at the Liège Seminary and then German philology at the Catholic University of Leuven, Alphons Thunus (whose father had lost his teaching position in Bütgenbach during the purge and had ultimately found work in the dairy works in Büllingen), taught at the Episcopal School of Sankt Vith as of 1964. Marked by the political injustice of his father's story, Alphons Thunus embarked on creating a 'German library' already while at the Liège Seminary to hold the then groundbreaking biblical studies and exegeses of German theologians. The unuttered but subtly practiced resistance against the Frenchification of clerical training concurred with the struggle of the people of Limburg for their own diocese, which was a recurrent subject at the Seminary in Liège as well. ${ }^{38}$ In addition to Latin, Greek and religion, as of 1964 Thunus also taught history - and his first school leaver's examination (for which Lorenz Paasch and Bruno Kartheuser also sat), caused quite a stir as historical themes such as the Versailles Treaty, World War II or the Holocaust were broached for the first time. ${ }^{39}$

In the Episcopal School of Sankt Vith, Alphons Thunus developed a movement as spiritus rector in the subsequent years, which called for German to be accorded equal treatment as a language of instruction in secondary education. At the core of this commitment however was not only the political determination to bring cultural autonomy to an institutional breakthrough, but more the day-to-day ambition for equal treatment of the population in the Eifel region which was

37 Cf. Episcopal School of St. Vith, Das Unterrichtswesen im deutschprachigen Gebiet, Sankt Vith 1968, 49 typewritten pages.

38 The Hasselt Bishopric was established in 1968. Clerical training was at that time divided into the so-called 'small' or 'philosophical seminary' in Sint Truiden, and the related 'big' or 'theological seminary' in Liège. The many Seminar students from the eastern cantons at the time met not only with Walloon students during their studies, but also with numerous fellow students from the Flemish-speaking municipalities of Limburg. The conflict over language between Flemings and Walloons that had been growing more and more aggressive since the end of the 1950s, thereby became a cohort defining event not only for students in Leuven, but also for seminarians in Liège.

39 In the interview with Lorenz Paasch, the latter remembered vividly his history lessons with Alphons Thuns, in which political - including contemporary - issues were broached for the first time. Alphons Thunus pointed out in the interview that the Holocaust was never broached in the seminary. 
severely disadvantaged on the linguistic, intellectual and economic front. Thunus was convinced that only when secondary education was made accessible to broader segments of the population, more equal treatment would follow in a second phase on the labour market and on the education of a critical mass of Germanspeaking intellectuals and academics. A necessary precondition to that end was to bolster German as a language of instruction as an end in itself, not as part of an autonomy debate reduced to language policy questions. In the aforementioned polemic pamphlet entitled 'The Education System in the German-speaking Territory', Thunus had argued that the recognition of the German-speaking community under the first state reform necessarily had to be accompanied by the transfer of competencies for the education system to the mandated Council of Culture. ${ }^{40}$

These demands had a tremendous impact - not least among colleagues at the Collège Patronné in Eupen. While efforts were being waged in the Sankt Vith school for the introduction of a German examination for French-speaking teaching staff in the eastern cantons, the leading representatives of the Collège Patronné in Eupen such as the maths teacher Jacques Keil or director Joseph Müllender established the 'interest group for bilingual instruction,' which was vehemently opposed to bolstering German as a language of instruction in secondary education. As a countermove, a campaign was conducted in Sankt Vith to establish a German-speaking Belgian section at the 'Council of European Teachers' whose first president was Michel Kohnemann.

It is no overstatement that both Catholic educational establishments - the Episcopal school in Sankt Vith and the Collège Patronné in Eupen - were the intellectual centres in which the controversial autonomy questions were discussed and negotiated. These tensions, which existed already in the mid 1960s, between an educational establishment defending the French assimilation policy, and another, which actually questioned that assimilation policy, would grow even sharper by the end of the 1960s, when a young generation of teachers brought Lorenz Paasch, Joseph Dries, Gerhard Palm and Bruno Kartheuser to the Episcopal School.

40 In point of fact, this study was also sustained by the practical insight that - with the ever increasing number of students in secondary schools more and more students came to the Episcopal School who could hardly speak French. Purely French-speaking instruction, especially in classes in the Technical Institute (TI) was established in 1962), was de facto inconceivable. Source: Interview with Georges Kalf (born in 1939), who taught mathematics in the TI mechanical - technical classes as of 1963. 
Extra-curricular activities were still very limited in the 1960s. Apart from football and gymnastics clubs as well as a few youth groups (scouts in Eupen, ${ }^{41}$ Chiro in Sankt Vith ${ }^{42}$ as well as some Groups of the Jeunesse Ouvrière Catholique (JOC) [Young Catholic Workers]), there were hardly any organised leisure activities, especially for girls. Consequently, for the minority at the time that could attend them, the secondary schools undoubtedly constituted a strong generational context. This applies also for those students, who went to the local secondary schools, as well as for those in Walloon educational establishments. For most students, attending a secondary school meant, in addition to life in a boarding school, an experience that had a marking biographical effect. ${ }^{43}$ As graduation from a secondary school with a school leaver's certificate in the 1950s and 1960s constituted almost automatically a step to higher education, the significance of the academic environment can scarcely be overestimated from the biographical and generational perspective. How important it was can be gauged from the next stage in the academic career of graduates of the Episcopal School or the Collège Patronné, many of whom went on to study at the Catholic University of Leuven.

\section{Politicisation from the outside}

The example of 'Eumavia Lovaniensis', the student fraternity founded in 1926 in Leuven shows how generational contexts can turn into generational units while at school, which then function as germ cells and engines for social change. The Eumavia, which stemmed for the major part from the academic 'elite' of eastern Belgium in the 1950s and 1960s, can be considered as a mirror image of eastern Belgian history, as Carlo Lejeune has shown. In this mirror image, the latent or explicit social as well as political tensions are shown through a magnifying glass,

41 Cf. Allzeit bereit! Pfadfinder in Ostbelgien, published by the G.o.E. Pfadfinder Obere Weser, Eupen 1991.

42 Cf. Andreas Fickers (ed.): Chiroleute erzählen: Von Gleichtschritt, Protest und neuen Abenteuern (1953-2003), Sankt Vith 2003.

43 All interviewees described their time at boarding school as a marking (positive as well as negative) biographical experience. The separation from the parental home, the strict regime of boarding schools run by Catholic clergymen, and the switchover to purely French-speaking instruction were experienced as a severe test by many students. On the other hand, boarding school life generated close social ties between students, which led to lifelong friendships. This applies also to the many students who, after graduating from secondary school, went to attend colleges in Arlon or Verviers - to become elementary school teachers, for instance. 
as it were. ${ }^{44}$ Particularly conclusive for the reconstruction of these tensions is a student from the Koblenz cleric Bernhard Kirfel, who devoted his thesis for his sociology degree to Eumavia in the academic year $1965 / 66 .{ }^{45}$ Relying on the ethnographic method of participatory observation, Kirfel subjected the activities of Eumavia members to a critical observation, which provides interesting insight into the social and political conception the students have of themselves. Kirfel's research was conducted at a time when the conflicts between French-speaking and Flemish students at the university were at their height. ${ }^{46}$ In discussions with the students, Kirfel tried to gauge their political opinion on the language conflict, and thus to draw indirect conclusions about the political self-conception of Germanspeaking students. The extreme polarisation of the student body - the slogan 'Walen buiten' [Walloons out] shouted by the Flemish students was countered by the Walloon students with 'Il n'ont pas de couilles, les Flamands', [The Flemish have no balls] -forced east Belgian students to their own positioning, often against their wishes. This compulsion to take sides was experienced as a dilemma by many Eumavia members, since a return to a neutral stance is scarcely possible in times of crisis. As many of these Eumavia members had friendly contacts with both Flemish and Walloon fellow students, opting exclusive for one or the other side was a difficult choice. ${ }^{47}$ In addition, the political orientation was made more difficult by the multiple identities of the students from eastern Belgium.

Kirfel cites an example to show how problematic the behavioural role of many Eumavia members was:

44 On the history of Eumavia, cf. Carlo Lejeune, Oh, alte Burschenherrlichkeit... Eumavia Lovaniensis, eine Studentenvereinigung als Spiegel ostbelgischer Geschichte, Hünningen 1989.

45 Berhard Kirfel, Studenten in Löwen. Flamen, Deutschbelgier, Wallonen. Die Löwener Studenten aus den deutschsprachigen Gemeinden der beglischen Ostkantone Eupen Malmedy - St. Vith in akademischen Jahr 1965/66. Eine teilnehemende Beobachtung, Löwen 1967.

46 On the Belgian student protest movement and the role of Leuven University see Gerd Rainer Horn. The Belgian Contribution to Global 1968. Views From Abroad : Foreign Historians on Belgium, special English-language issue of Revue Belge d'Histoire Contemporaine, 2005, pp.597-635; Jo Tollebeek, Liesbet Nys, Lieve Gevers, Louis Vos, Ruben Mantels, De stad op de berg. Een geschiedenis van de Leuvense universiteit sinds 1968, Leuven: Universitaire Pers Leuven, 2005.

47 Eumavia members from the Eifel region in particular often cultivated good contacts with the Flemings, because they usually stayed in Flemish Leuven during the weekends and thus came into closer contact with the local population and Flemish students. 
One student said: 'If things get any worse here in Leuven, we'll have to flee one day.' I asked: 'Who is we?' The student replied: 'The Walloons.' However, in the course of the conversation, he explained 'We feel drawn to the Germans even more.' The word 'we' thus takes on a different content depending on the situation, depending on which sub-role one has to assume. ${ }^{48}$

The overlapping of two complex phenomena - on the one hand, the highly politicised atmosphere at the university ${ }^{49}$, and on the other what Kirfel described as the 'chameleon-like' identity of the eastern Belgians - ultimately led to a 'silent' rather than 'loud' politicisation of Eumavia in the 1970s, which had for long made sure that political and ideological differences be kept out of its associative life..$^{50}$ Of interest in the context of the underlying question here as to the significance of the generational units in the student milieu is that the incipient politicisation of the Eumavia members - as in the case of the emancipation debate - occurred along clear social structure and geographic lines. The boundaries between 'proBelgian' and 'pro-German' camps, as they were called, within Eumavia, could also be drawn rather precisely along geographic lines, according to Kirfel: 'People from the north (canton of Eupen) tended towards a pro-Belgian position, whereas students from the cantons of Malmedy and Sankt Vith tended particularly to the pro-German subgroup. ${ }^{51}$ Both 'camps' were moreover distinguished by the social structure: Whereas the 'pro-Belgian' minded Eumavia members from the Eupen region came predominantly from middle to upper class backgrounds (professions, civil servants, clerical employees), the majority of the 'pro-German' minded Eumavia members from the Eifel region stemmed from the bottom layer (manual workers and farmers). ${ }^{52}$ Accordingly, in Leuven we find both a continuation as well as a spatial-institutional conflation of that polarisation, which was prepared at the secondary school level (Episcopal School in St. Vith versus Collège Patronné).

48 Kirfel, Studenten in Löwen, 41.

49 Cf. Mark Derez, Ingrid Depraetere, Louis Vos, Johan Mahieu, Wivina Van der Steen, Studentenprotest in de jaren zestig: de stoute jaren, Tielt: Lanno 1988.

50 In his sociological analysis of Eumavia, Carlos Lejeune speaks of a 'silent politicisation' of Eumavia, which was gradually drawn in by both 'engaged' groups of opinion in the Leuven student body (Flemish/Walloons). Cf. Lejeune, Oh, alte Burschenherrlichkeit, 51.

51 Kirfel, Studenten in Löwen, 13.

52 Naturally, these classifications did not cover all the members of Eumavia, and each 'camp' could have members from Eupen or the Eifel region among its ranks. Nevertheless, Kirfel's thesis is corroborated in the oral history interviews by former Eumavia members such as Lorenz Paasch, Joseph Dries, Peter Thomas, Leonard Schifflers and Freddy Derwahl. 
As Carlo Lejeune has shown, Eumavia members, who were allegedly 'neutral' in the language conflict, were de facto subjected to a 'forced classification,' which compelled them, willingly or unwillingly, to come out for or against certain political points of view (such as the expansion of the cultural autonomy or the equal treatment of the German language in secondary education). ${ }^{53}$ From the socio-psychological perspective, it comes as no surprise that generational contexts formed at secondary school would lead to socio-cultural generational units when studying in Leuven, whose effectiveness -as in the case of the political history of the German-speaking Community - would be visible for decades to come. ${ }^{54}$ From the generational historical perspective, it scarcely comes as a surprise that the Episcopal School in Sankt Vikt had developed into an intellectual nucleus of a new political movement in the 1960s, which went beyond political party activities. ${ }^{55}$

\section{An experience or narration generation?}

When we listen to the stories of the protagonists of the ' 73 generation, it is difficult not to be struck by the dramatic dimension of the narratives. The unbelievable wealth of events and developments, which consolidated into a phase of social, political and cultural dynamism as well as social change at the end of the 1960s, beginning of the 1970s at the international, national as well as regional level, is reflected to an astonishing degree in those narratives and remembrances of eastern Belgian contemporary eye witnesses who were interviewed for this study. The recollections of those interviewed are dominated by the feeling of living through and of having helped to shape, albeit partially a period of intensive political debates, strategic considerations, provocative actions and revolutionary demands. Contemporary analyses and retrospectives, as in Hubert Jenniges 'Hinter ostbelgischen Kulissen' or Gerhard Palm's obituary on Hubert Jenniges, speak of 'glaring forces' and 'times of events. ${ }^{36}$ The manifest 'movements' or 'currents' in many

53 Lejeune, Oh, alte Burschenherrlichkeit, 51.

54 I am thinking here primarily of the history of the parties of the German-speaking Belgians, whose leaders included many 'old boys' of Eumavia. Cf. Leonie Neuens, A la base d'un parti régionaliste La creation du PDB (Parti des Belges de langue allemande) en 1971: acteurs et controversies; unpublished master's thesis in history, University of Liège, 2013.

55 The 'hot iron' action and the establishment of sheltered workshops and the free healthcare funds are worth mentioning here.

56 Jenniges, Hinter ostbelgischen Kulissen, 117. 
areas of social and political life inside and outside the east cantons appear to have been so marking and singular that they can readily be qualified as 'revolutionary'.

More and more voices are recently heard, however, increasingly also from the ranks of the ' 68 generation, which are calling for a self-critical approach to the interpretation of individual or collective biographical narratives. ${ }^{57}$ There should be no doubt at this point, that the 'hot phase' of the autonomy debate (1967-1973) was a particularly eventful period in the history of eastern Belgium. It is nonetheless important to assume a critical stance both as regards the narrative construction of the recollection of the historical actors interviewed and to compare it with one's own narration perspective applied here. Bernd Weisbrod has rightly indicated that the ' 68 generation is a 'wondrous proliferation of the narration generation rather than an experience generation in the strict sense ${ }^{58}$ i.e.: Actually, there was only a small but radical minority, which participated in demonstrations or the creation of alternative events proved effective in attracting media coverage. That minority was nonetheless sufficient, according to Weisbrod, as it would today appear that anyone in a position of authority today was part of it!

The speeches and festivities for the $40^{\text {th }}$ 'anniversary' of the establishment of the Board of the German Cultural Society in 2013 do provide sufficient source material to strengthen Weisbrod's thesis of 'proliferating political and public confirmation' of having belonged to the ' 73 generation. Most of them have actually been silent witnesses of that time. Similarly, the 'cultural revolution' which is often mentioned in the same breath with the ' 68 generation - trickled slowly into eastern Belgium only in the mid 1970s. There was not much trace of 'sex and drugs and rock ' $n$ roll' in the eastern Belgian media or in social life at the end of the 1960s/ beginning of the 1970s..$^{59} \mathrm{~A}$ generational conflict emerged in Eumavia and in youth groups such as Chiro in Sankt Vith only in the mid 1970s, during the course of which progressive ideas and life styles came increasingly into conflict with

57 Such as Wolfgang Kraushaar, who takes a critical stance on the concept of generations in the context of the ' 68 movement. Wolfgang Kraushaar, Achtundsechzig. Eine Bilanz. Berlin: Propyläen 2008. Götz Aly is even more judgemental of himself and his generation in: Götz Aly, Unser Kampf, 1968 - ein irritierter Blick zurück, Frankfurt am Main: S. Fischer Verlag, 2008.

58 Weisbrod, Generation und Generationalität in der Neueren Geschichte, 3.

59 Music, which today has become the emblem of the generation awakening in the sixties and seventies, played a central role for only one of the contemporary witnesses interviewed, Robert Oberecken. 
conservative standards and values. ${ }^{60}$ At the peak of the student revolts in Paris and Berlin in May 1968, there was little protesting to be seen in Leuven and Liège. To be sure, one or another student had read Herbert Marcuse's 'The One Dimensional Man' and had heard of Theodor W. Adorno's and Max Horkheimer's 'Dialectic of the Enlightenment,' but abstract intellectual debates were not in the foreground of the protest movement either in Leuven or in Liège. Whereas the ' 68 movement in Leuven was overshadowed entirely by the language conflict and the division of the university, ${ }^{61}$ in Liège, where the subsequent protests in February 1969 culminated in a week-long occupation of the auditorium, the demands were focused chiefly on a democratisation of the university. ${ }^{62}$ The media consumed by many young people and students consisted essentially of reading newspapers and magazines (above all Der Spiegel) and occasionally listening to radio broadcasts - the new medium television, which would turn into the central catalyst of the images of the revolution,' was pretty much absent. ${ }^{63}$ These factors suggest that the ' 73 generation was more of a transition generation characterised by genealogical tensions then a founding generation of the political and cultural autonomy which the Germanyspeaking Community enjoys today in the federal state of Belgium. The political and cultural confrontation at the end of the sixties/beginning of the seventies was not characterised by radical demands (even though older contemporary witnesses

60 In Eumavia, this change in values was perceptible particularly through the increasing tensions between the Activitas and the 'Alte Herren' (old boys); in Chiro through the abolition of traditions and symbols (e.g. uniforms), which were perceived as authoritarian and outmoded. Instead, topics such as political engagement, civil courage, sexuality and emancipation came to the fore in the educational debates. Cf. Lejeune, Oh, alte Burschenherrlichkeit, 55-61; also, Fickers, Chiroleute erzählen, preface.

61 'The student rebellion of the foreigners (Berlin, Paris) was viewed from a distance in the sleepy and sclerotic Leuven. The barren rudiments of a social discussion and questioning were completely obscured and overlaid by the Belgian nationalism discussion, according to the recollection of Bruno Kartheuser, cited in Lejeune, Oh, alte Burschenheerlichkeit, 56. However, Kartheuser's rebellion was evidently limited to reading Der Spiegel, which since it was forbidden reading material in the seminary - he went to his fellow student Joseph Dries to read the periodical, for whom the weekly purchase of Der Spiegel amounted to a significant investment. Source: Interview of Joseph Dries.

62 Cf. Danielle Bajomée, Le mai 68 liégois, in: Nancy Delhalle/Jacques Dubois/Jean-Marie Klinkenberg (eds.), Le tournant des années 1970. Liège en effervescence, Brussels: Les Impressions Nouvelles 2010, 13-22.

63 On the significance of television in the creation of a critical public sphere during the 'long sixties,' cf. Christina von Hodenberg, Mass Media and the Generation of Conflict: West Germany's Long Sixties and the Formation of a Critical Public Sphere, in Contemporary European History, vol. 15 (2006) no. 3, 367-395. 
may have experienced them as such) nor by utopian life plans, but by the practical effort to bring about a change in the cultural and political landscape. This effort was characterised by reaching a compromise between old and now, traditional and progressive, and not by the activist or propagandistic staging of radical positions. Eupen and Sankt Vith were not Paris or Berlin, and Lorenz Paasch was not the eastern Belgian Cohn-Bendit. Without the importance of the older, wise and intelligent people,' Gerhard Palm put it succinctly in retrospect, many of the tempestuous positions of a few 'young savages' from the Eifel region would probably have had few consequences. ${ }^{64}$

In conclusion, it can be stated that as set out herein, the ' 73 generation was more of an elite phenomenon than an accurate description of a generational stratum comprising broader social classes in Mannheim's meaning of the term. The focus of this narrative on a small circle of historical actors and institutions has entailed that the largest part of the eastern Belgian population has been left out. The mass of 'silent' participators of an experience generation unfortunately did not get a word in. Nevertheless, I believe that the concept of generations has generated heuristic added value, without which certain aspects of the autonomy debate would have emerged less clearly if at all. And if it has brought more historical questions than answers, it has been more to the service than to the detriment of the future regional historiography. For: 'C'est la question qui construit l'object historique.65 [It is the question that constructs the historical object].

64 Gerhard Palm here names Reiner Pankert, Wilhelm Pip, Michel Kohnemann, Michel Louis, Norbert Scholzen and Rudi Pankert. Cf. Palm, Gedenkfeier für Hubert Jenniges, 7 65 Antoine Prost, Douze leçons sur l'histoire, Paris: Éditions du Seuil 1996, 79. 


\section{Grenzregionforschung trifft auf Kindheitsforschung. Eine europäische Begegnung}

\section{Deutsche Abstracts}

\section{Einleitung (Machteld Venken)}

Wenngleich es im 20. Jahrhundert wesentliche Veränderungen im europäischen Grenzgefüge gab und europäische Staaten sich stärker für Kinder interessierten, fehlt es immer noch an Forschung über Kindheit in Grenzregionen. Dieses Werk bietet eine vergleichende Analyse der Geschichte von Kindern aus Grenzregionen. Es basiert auf den Forschungsergebnissen von Grenzgebietsforschern, die schildern, wie das Grenzland zentral für die Machtkämpfe zwischen den Staaten war, und auf Kindheitsforschern, die darlegen, wie genau sich Politik von Staaten in ihrer Politik gegenüber Kindern niederschlägt. Die Beiträge legen unterschiedliche neue Erkenntnisse und eine neue Hypothese offen.

Nicht die Eltern selbst, sondern ihre Kinder waren es, die eine entscheidende Rolle in der Verwirklichung des friedlichen Europas spielen sollten, das die Vertreter auf internationalen Friedenskonferenzen im Sinn hatten, als sie die Souveränitäten der Grenzregionen veränderten, in denen diese Kinder lebten. Jeder der einzelnen Beiträge zeigt, wie komplex die Nationalisierungsmaßnahmen in diversen, oftmals vorher unbekannten Bereichen des Lebens von Kindern aus Grenzregionen waren. Ebenso haben sie unsere Einsichten in die Dichotomie vertieft, die zwischen der nationalistischen Politik gegenüber Schulkindern in Grenzregionen während der Zwischenkriegszeit und den manifesten nicht-nationalen Praktiken dieser Kinder bestand, welche von Historikern zuvor erforscht wurden. Sie werfen ein Licht auf andere Aspekte der Lebenswelt von Zwischenkriegskindern und ebenso auf die nationalistische Erziehung in Grenzregionen nach dem Zweiten Weltkrieg.

Ein Vergleich der Beiträge ermöglicht es, eine neue Hypothese zu wagen. Trotz der unterschiedlichen Vorstellungen von Ost und West, die die Entscheidungen der Friedensverhandelnden nach beiden Weltkriegen beeinflussten, haben Kinder aus Grenzregionen der östlichen und westlichen Hälfte des europäischen Kontinents auf erstaunlich ähnliche Weise kreative Praktiken erschaffen, die zur Entstehung eines sozial kohäsiveren Europas beigetragen haben. Dies scheint darauf hinzuweisen, dass jegliche Definition von Europäisierung die Spezifizität von unterschiedlichen historischen Akteuren nicht außer Acht lassen sollte und sich nicht nur auf den Diskurs beschränkt, den die Machthabenden zu einer bestimmten Zeit in der Vergangenheit führten. 


\section{Zwischen Frankreich und Deutschland, benachteiligte Kinder im Elsaß zwischen dem Anfang des 19. Jahrhunderts und den 30er Jahren des 20. Jahrhunderts: Die Fürsorge für Waisenkinder in Straßburg (Catherine Maurer, Gabrielle Ripplinger)}

Bezogen auf das Elsaß, einer Grenzregion par excellence, soll die Aufmerksamkeit auf eine Gruppe gelenkt werden, die gelegentlich als marginal angesehen wird, die sich jedoch im Schnittpunkt mehrerer wesentlicher Fragestellungen der Geschichte der Kindheit befindet: dem Verhalten von Erwachsenen und von Familien gegenüber Kindern, den verschiedenen Ausprägungen der Bildungspolitik wie auch der öffentlichen Fürsorge gegenüber Kindern. Betrachtet wird eine besondere Gruppe benachteiligter Kindern, die zeitweise oder für immer ohne ihre Familien lebten: die Waisenkinder. Die Fürsorge gegenüber Waisenkindern in Straßburg zwischen dem Anfang des 19. Jahrhunderts und dem Ende der 30er Jahre des 20. Jahrhunderts soll hier als Fallbeispiel dienen.

Drei Fragestellungen leiten die Überlegungen: Welche Rolle spielte die geografische Lage des Elsaß bei der Einführung gesetzlicher Regelungen zur Fürsorge vernachlässigter Kinder, vor allem Waisenkinder, in der Region und welche konkreten Auswirkungen hatte sie auf den alltäglichen Betrieb der Waisenhäuser, insbesondere des städtischen Waisenhauses? Welche Rolle spielten französische und deutsche Einflüsse bei der Konzeption, vor allem architektonisch, der städtischen Einrichtung und in ihrem Alltag? Und schließlich, hatten die Bewohner und das Personal des Waisenhauses angesichts der Grenzlage eine besondere Einstellung zur nationalen Frage? Mit diesem Ansatz der Mikro-Geschichte sollen weiterführende Perspektiven der Geschichtsschreibung, wie etwa die der Nationalismen und ihre Konfrontation im 20. Jahrhundert, unterfüttert werden.

\section{Kindheit in der Memelregion (Ruth Leiserowitz)}

Die Bezeichnung 'Memelgebiet' wurde 1919 auf der Friedenskonferenz von Versailles geprägt und bezog sich auf den nördlichen Streifen von Ostpreußen, der im Süden von der Memel begrenzt wurde und nordwärts bis zu dem Dorf Nimmersatt (Nemirsate) an der Ostsee reichte. Der Artikel 99 des Friedensvertrags von Versailles besiegelte die Abtrennung des Memelgebietes vom Deutschen Reich. Nachdem Litauisches Militär am 15. Januar 1923 das Gebiet einnahm, kam es aufgrund von Verhandlungen der Entente Staaten mit Litauen zu der Memelkonvention vom 8. Mai 1924, wodurch dem Gebiet innerhalb der Republik Litauen Autonomie gewährt wurde. Zwischen 1920 und 1937 war Memel eine Region mit einem deutschen Kultur- und Wirtschaftsleben. Bis 1937 ließen die Autonomiebehörden keinerlei 
öffentlichen Antisemitismus zu. Am 22. März 1939 kam das Gebiet an Deutschland zurück, nachdem der litauische Außenminister Juozas Urbšys gezwungen worden war, ein Ultimatum zu unterzeichnen.

Die Mehrheit der Kinder in der Region erhielt eine gute Ausbildung. Dabei begegneten sich deutsche, litauische und jüdische Kinder einzig in der Schule. Die Kinder waren unabhängig von ihrer nationalen Zugehörigkeit sehr aktiv in ihrer Freizeit, vor allem im Sport und bei den Pfadfindern. Alle Kinder in der Region, Deutsche, Litauer und Juden wurden von den territorialen Konflikte und Krieg betroffen, wodurch ihre Kindheit unerwartet und abrupt beendet wurde. Dieser Text untersucht die Erinnerungen unterschiedlicher Kinder. Er versucht aufzuzeigen, dass die Mehrheit der Eltern, unabhängig von ihrem nationalen und politischen Hintergrund versuchte, ihren Kindern eine unpolitische und behütete Kindheit, zu sichern.

\section{Jugendbewegungen im Elsass und die Frage der nationalen Identität, 1918-1970 (Julien Fuchs)}

Dieses Kapitel untersucht die Jugendorganisationen des Elsass, einer Region am Scheideweg Europas, zwischen Frankreich und Deutschland. Genauer gesagt, wird es auf den Zeitraum zwischen 1918 (da die moisten dieser Organisationen nach dem Ersten Weltkrieg entstanden) und den frühen 1970er Jahren konzentrieren (als sie im Niedergang begriffen waren). Es werden insbesondere fünf Phasen der Entwicklung dieser Organisationen analysiert - Phasen, in denen junge Elsässer spezifische Formen der Einbeziehung erlebten: (i) von 1918 bis 1932, in einer Zeit der Wiederaneignung des Französisch Lebensstils; (ii) von 1932 bis 1939, mit dem Aufstieg des regionalen Separatismus; (iii) von 1940 bis 1945 it der Annexion der Region durch Deutschland; (iv) von 1945 bis 1958, mit dem Prozess des lokalen Wiederaufbaus in einer durch und durch 'französischen' Umwelt; und (v) von 1958 bis 1970, als die jungen Elsässer von tiefgreifenden sozialen und kulturellen Veränderungen betroffen waren. Das Ziel ist es, zu zeigen, dass letztendlich Jugendorganisationen im Elsass $z$ u einer Bejahung der Jugend, besonders im Hinblick auf die Dialektik Region/ Land, beigetragen haben. Dies geschah auf eine Weise, die immer relativ spezifisch war. Jedoch führten die regionalen Besonderheiten nicht zum Entstehen von Partikularismen, sondern trugen vielmehr dazu bei, eine Geschichte zu situieren, in der einzelne patriotische, religiöse und politische Angelegenheiten tief ineinander verwoben waren. 


\section{Das Alltagsleben von Kindern im deutsch-polnischen Grenzraum in der frühen Nachkriegszeit (Beata Halicka)}

Die 1918 infolge der Wiedererrichtung des polnischen Staates neu geschaffene polnisch-deutsche Grenze wurde 1945 etwa 200 Kilometer nach Westen verschoben. Als Ergebnis der erzwungenen Migrationen und des in vielen Fällen nahezu vollständigen Austauschs der Bevölkerung erlebte die Grenzregion eine signifikante soziale Transformation. Eine wichtige Quelle für meine Forschungen zum Alltagsleben der Einwohner dieser Grenzzone waren autobiographische Dokumente, insbesondere die Erinnerungen von Neusiedlern, hauptsächlich von Polen, die diese Region nach dem Krieg besiedelten. Dieser Artikel präsentiert die Ergebnisse der Arbeit, unter besonderer Berücksichtigung von Kindheitserinnerungen und dem Mechanismus der Konstruktion von Gedächtnis. Das Schicksal der in dieser Region nach dem Zweiten Weltkrieg lebenden Kinder wird sowohl aus ihrer eigenen Perspektive, als auch anhand von Zeugnissen von Erwachsenen, die ihr Familienleben, ihre Arbeit in Schulen oder Institutionen beschreiben, gezeigt. Die Kernfragen beinhalten Themen wie die schwierigen Lebensbedingungen in der frühen Nachkriegszeit, den Umgang mit traumatischen Kriegserfahrungen und die Sehnsucht nach der verlorenen Heimat, die Anfänge einer polnischen Erziehung, die durch einen nationalistischen bzw. patriotischen Geist geprägt war, sowie Diskriminierung und Ausgeschlossenheit der in Polen verbliebenen deutschen Kinder.

\section{'Wir bleiben was wir sind?' Deutsche Identitäten in Nordschleswig in der Kindererziehung nach 1945 (Tobias Haimin Wung-Sung)}

Wie viele andere ethnischen Deutschen in Europa, in den Jahren 1933 bis 1945, unterstützte auch die deutsche Minderheit in Dänemark das Nazi-Regime Deutschlands und seine territoriale Expansionspolitik. Allerdings anders als die meisten anderen deutschen Minderheiten in Europa entgingen die Deutschen in Dänemark einer nach dem Krieg forcierte Deportation oder Assimilation. Sie schafften es, in ihrer Heimatregion zu bleiben und die Minderheit baute sich in den kommenden 25 Jahren ein gemeinschaftliches Leben auf. Die Minderheit sah vor allem Bildung als einen immanenten Bestandteil zur Sicherung des eigenen Fortbestehens der Gruppe an. Jedoch hatte der Erfolg Schulen wieder aufzubauen auch Folgen für die Minderheit: Im Laufe der Zeit veränderten sich nicht nur die konstruierten Identitäten selbst, sondern auch die neuen Schulen sowie die Gesellschaft von der sie selbst ein Teil waren. Durch die Analyse des Prozesses der Rekonstruktion des Bildungswesens zwischen 1945 und 1970 verdeutlicht der Artikel genau jene Identitätstransformationen. Außerdem zeigt der Artikel, dass Kinder und Jugendliche der deutschgesinnten Minderheit im 
Nordschleswig der Nachkriegszeit Schulen besuchten, die schrittweise Feindseligkeiten zwischen Mehrheiten und Minderheiten sowie nationalen Separatismus mit transnationaler Inklusion ersetzten.

\section{Generationenkonflikte, der Geist von '68 und kulturelle Eman- zipation in der deutschsprachigen Gemeinschaft Belgiens. Ein historischer Essay über die '73er Generation' (Andreas Fickers)}

Veränderungen lagen in der Luft - so könnte man die gesellschaftliche Stimmung Ende der 1960er, Anfang der 1970er Jahre wohl am besten beschreiben. International trat der Generationenkonflikt zwischen der Nachkriegsgeneration, den so genannten 'Baby-Boomern', und jener Generation, die den Zweiten Weltkrieg als Jugendliche oder junge Erwachsene erlebt hatten, in Form von Studentenprotesten, Anti-Kriegsbewegungen und neuen Lebensentwürfen zutage. Es ist wohl kaum ein Zufall, dass sich zu dieser Zeit auch in Ostbelgien der Protest regte. Oder doch? Wogegen lehnten sich die 'jungen Wilden' im deutschsprachigen Belgien auf? Vom Geist der '68er beseelt, so die These, schlugen vor allem junge Eifler neue Töne an, die die politische Landschaft - mehr denn die sozialen oder kulturellen Milieus Ostbelgiens - nachhaltig prägen sollte. 



\section{Notes on Contributors}

Andreas Fickers is Professor for Contemporary and Digital History at the University of Luxembourg. His fields of specialisation are European history of technology, transnational media history and digital historiography. Originating from the German-speaking community of Belgian, he has been involved in several research projects on the history of the german speaking minority in Belgium. He is currently directing the interdisciplinary Centre for Contemporary and Digital History (C2DH) and coordinator of a Doctoral Training Unit (DTU) on 'Digital History and Hermeneutics'.

Julien Fuchs is Senior Lecturer at the University of Western Brittany (Brest, France). He teaches on the history of youth, sport and physical education. His main research interests include youth movements and bodily practices in their relationship with local identities. He is the author of Toujours prêts. Scoutismes et mouvements de jeunesse en Alsace, 1918-1970 (Strasbourg: La Nuée Bleue, 2007).

Beata Halicka is Associate Professor for cultural history of East Central Europe at the Polish-German Research Institute at the Collegium Polonicum in Słubice, which is a joint facility of the Polish University of Adam Mickiewicz in Poznań and the European University Viadrina in Frankfurt (Oder). She is the author of five books and numerous articles and the editor of many collective publications. Recently she published her study on Poland's Wild West - forced migration and cultural appropriation of the Oder region 1945-1948 in German Schöningh Verlag in 2013 and in Polish in Universitas Press in 2015. Her research interests are: nationalism und forced migrations in Europe, constructions of identities in border regions, German-Polish relations, issues relating to the culture and politics of remembrance.

Ruth Leiserowitz is Deputy Director at the German Historical Institute in Warsaw and professor for East European History at the Humboldt University Berlin. Her research is focused on European history of the 19th and 20th century with a focus on transnational history, Baltic history, Jewish history, and the history of memory and border regions. Her last publication: Heldenhafte Zeiten. Die polnischen Erinnerungen an die Revolutions-und Napoleonischen Kriege 1815-1945 (Heroic Times. The Revolutionary and Napoleonic Wars in Polish Memories 1815-1945) will be published in 2016 Paderborn: Schöningh. 
Catherine Maurer is Professor of Contemporary History of Germany and France at the University of Strasbourg (France). Her research concerns the social and cultural history of religion in Germany and France. She has published in particular Les espaces de l'Allemagne au XIXe siècle. Frontières, centre et question nationale (Strasbourg, Presses universitaires de Strasbourg, 2010), La ville charitable. Les œuvres sociales catholiques en France et en Allemagne (Paris, Éditions du Cerf, 2012) and L'espace rhénan, pôle de savoirs (Strasbourg, Presses universitaires de Strasbourg, 2013).

Gabrielle Ripplinger was a Master's Student in History in the University of Strasbourg (France). Her Master's degree Thesis under the supervision of Catherine Maurer Lorphelinat municipal du Neudorf (1907-1940). La question de la prise en charge municipale de l'enfance orpheline à Strasbourg dans la première moitié $d u$ XXe siècle was defended in June 2015. She is currently studying at Sciences Po Grenoble and pursuing a master's degree program specialized in Public policies and social change, with more particular focus on 'Cities, territories and solidarity'.

Machteld Venken is a Slavist and a Historian from the Catholic University of Leuven (KU Leuven). After holding fellowships at the German Historical Institute in Warsaw and the College of Europe Natolin Campus, she was a Lise Meitner Fellow at the Ludwig Bolzmann Institute for European History in Vienna. Currently, she is a Senior Postdoctoral Researcher (Elise Richter Fellow) at the University of Vienna. She is the author of a number of publications, including Straddling the Iron Curtain? Immigrants, Immigrant Organisations, War Memories (Peter Lang 2011), and co-editor (with Maren Röger) of the special issue: 'Growing up in the Shadow of the Second World War. European Perspectives' in: European Review of History / Revue européenne d'histoire (Special Issue) 22 (2015).

Tobias Haimin Wung-Sung has been affiliated with the University of Southern Denmark's Centre for Border Region Studies in Sønderborg since 2013. He holds an MA in European History from University College London, and his main research interest is Danish and German border region history in transnational perspective. In September 2016, he submitted his PhD-thesis: Beyond the Border: A History of Minority Youth Identities in the Danish-German Border Region, c. 1955-71. He was awarded a PhD in Social Sciences in January 2017 and is now a Postdoc at The University of Southern Denmark's Center for Border Region Studies. 


\section{Index of Places}

Aabenraa 143, 144, 146, 148, 150-153, 157

Aiguebelle 102

Alsace 26-29, 34, 37-39, 85-113

Alsace and Lorraine (Alsace-

Lorraine) 11, 25, 28

Andlau 50

Belgium 28, 33, 37

Beuggen 49

Bohemia 28

Bohemian Lands 15

Bouchet Lake 103

Brive-la-Gaillarde 101

Broager 148

Clermont-Ferrand 103

Coadjuthen 67, 72-74, 77, 79

Colmar 50, 53, 54, 91, 93, 100, 104

Combovin 102

Copenhagen 39

Crimea 20

Czechoslovakia 11, 32

Denmark 28, 33, 39

Dordogne 101

Düsselthal 49

Dybbøl 152

Dzierżoniów 131

East Brandenburg 30

East Prussia 30

Ebermünster 50

Eupen 163, 165-169, 174, 176-180, 184

Eupen-Malmedy 11, 24, 26, 28, 31, 32, 35,36

France 13, 19, 25-28, 37, 38

Gdańsk 30

Germany 11, 17, 19, 25, 27, 28, 31, 33, $34,38,39$

Greece 24

Gubin 136
Guebwiller 50, 93, 101

Habsburg Empire 11, 15, 24

Haderslev 149

Hilsenheim 50

Hlučin region 11, 28, 29, 31, 32, 38

Hunebourg 98

Kaliningrad 30

Kaunas 69, 79

Lausanne 24

Le Puy en Velay 102

Leuven 33

Lille 61, 62

Lithuania 11, 27, 30, 35

Lower-Rhein (Bas-Rhin) 99, 104, 109

Luxembourg 28

Lyon 102

Malmedy 165-169, 174, 179, 180

Memel / Klaipeda 27

Memel region 11, 24, 27, 28, 30, 31, 35

Mikołajki Pomorskie 133

Moravia 28

Moselle 91

Mulhouse 50, 53, 54, 93, 96, 101

Mulhouse-Dornach 50, 54

Munich 28

Netherlands 28

Neuf-Brisach 50

Niederbronn 50, 54

Nimmersatt, Nemirsatè 65

North Schleswig 11, 28, 33, 35-37, $139,140,143-147,149,151-154$, 156-162

Obernai 96

Ottoman Empire 11, 15

Paris 102

Périgueux 101

Poland 19, 20, 24, 28-30, 36, 37

Pomerania 30 
Posen - Poznań 30, 31, 53, 125, 127, 130, 132, 136

Potsdam 119

Potsdam 30

Prague 28

Prussian Empire 24

Pyrzany 115, 116

Republic of Lithuania 65, 66, 68

Rhineland 19

Russian Empire 11, 15, 24

Saint-Léonard-de-Noblat 102

Sankt-Vith 28

Saurier 102

Saverne 50, 55

Schleswig-Holstein 143, 156, 157

Silesia 15, 16, 24, 25, 29-32

Sønderborg 153, 157

St.Vith 163, 168, 169, 174-180, 182, 184

Strasbourg 26, 27, 34, 43, 45-51, 53-57, 59-62, 87, 90-96, 98, 101, $102,104,107-109$

Sudetenland 28

Świebodzin 132
Szczecin 125, 131

Szczecinek 127

Tarnowskie Góry 132

Thann 50

Tinglev 157

Toulouse 101

Turkey 24

Uciechów 131

Uge 152

Upper Silesia 15, 16, 24, 25, 29-32

Upper-Rhein (Haut-Rhin) 100, 104

Verdun 96

Vernet-la-Varenne 102

Versailles 11, 19, 24

Vieil-Armand 96

Vieille-Brioude 102

Vosges 96, 111

Warsaw 117, 125, 127

Weimar 16

West Prussia 30

Willerhof 50

Yalta 20, 120

Zielona Góra 125 


\section{Warsaw Studies in Contemporary History}

Edited by Dariusz Stola / Machteld Venken

Vol. 1 Maciej Górny: The Nation Should Come First. Marxism and Historiography in East Central Europe. 2013.

Vol. 2 Zofia Wóycicka: Arrested Mourning. Memory of the Nazi Camps in Poland, 1944-1950. 2013.

Vol. 3 Anna Witeska-Młynarczyk: Evoking Polish Memory. State, Self and the Communist Past in Transition. 2014.

\section{Studies in Contemporary History}

Edited by Dariusz Stola / Machteld Venken

Vol. 4 Joanna Wawrzyniak: Veterans, Victims, and Memory. The Politics of the Second World War in Communist Poland. Translated by Simon Lewis. 2015.

Vol. 5 Jerzy Kochanowski: Through the Back Door. The Black Market in Poland 1944-1989. Translated by Anna Wróbel. 2017.

Vol. 6 Machteld Venken (ed.): Borderland Studies Meets Child Studies. A European Encounter. 2017.

www.peterlang.com 